
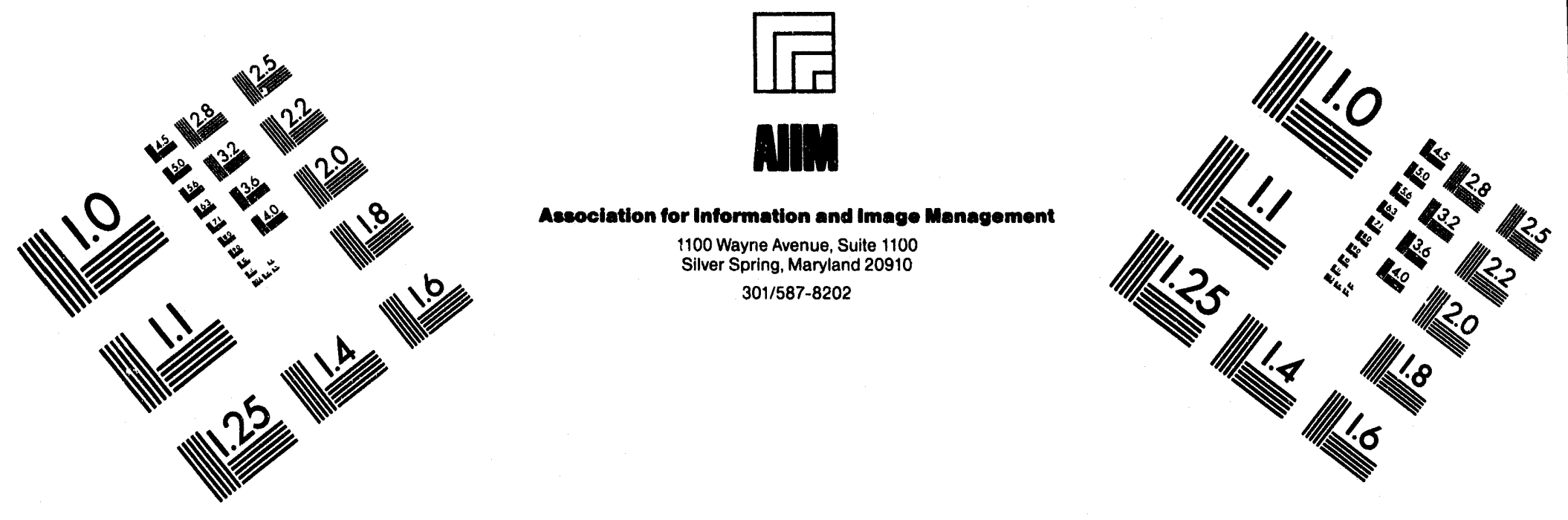

\title{
Centimeter
}

$\begin{array}{llllllllllllllll}1 & 2 & 3 & 4 & 5 & 6 & 7 & 8 & 9 & 10 & 11 & 12 & 13 & 14 & 15 & \mathrm{~mm}\end{array}$

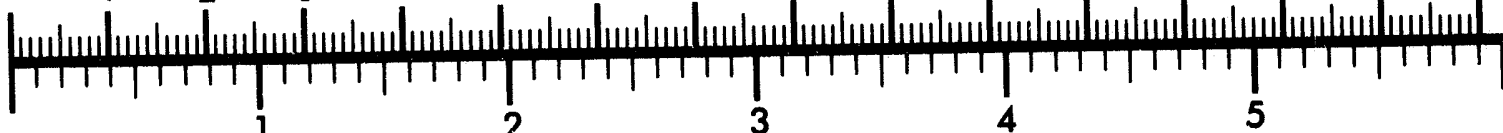
Inches
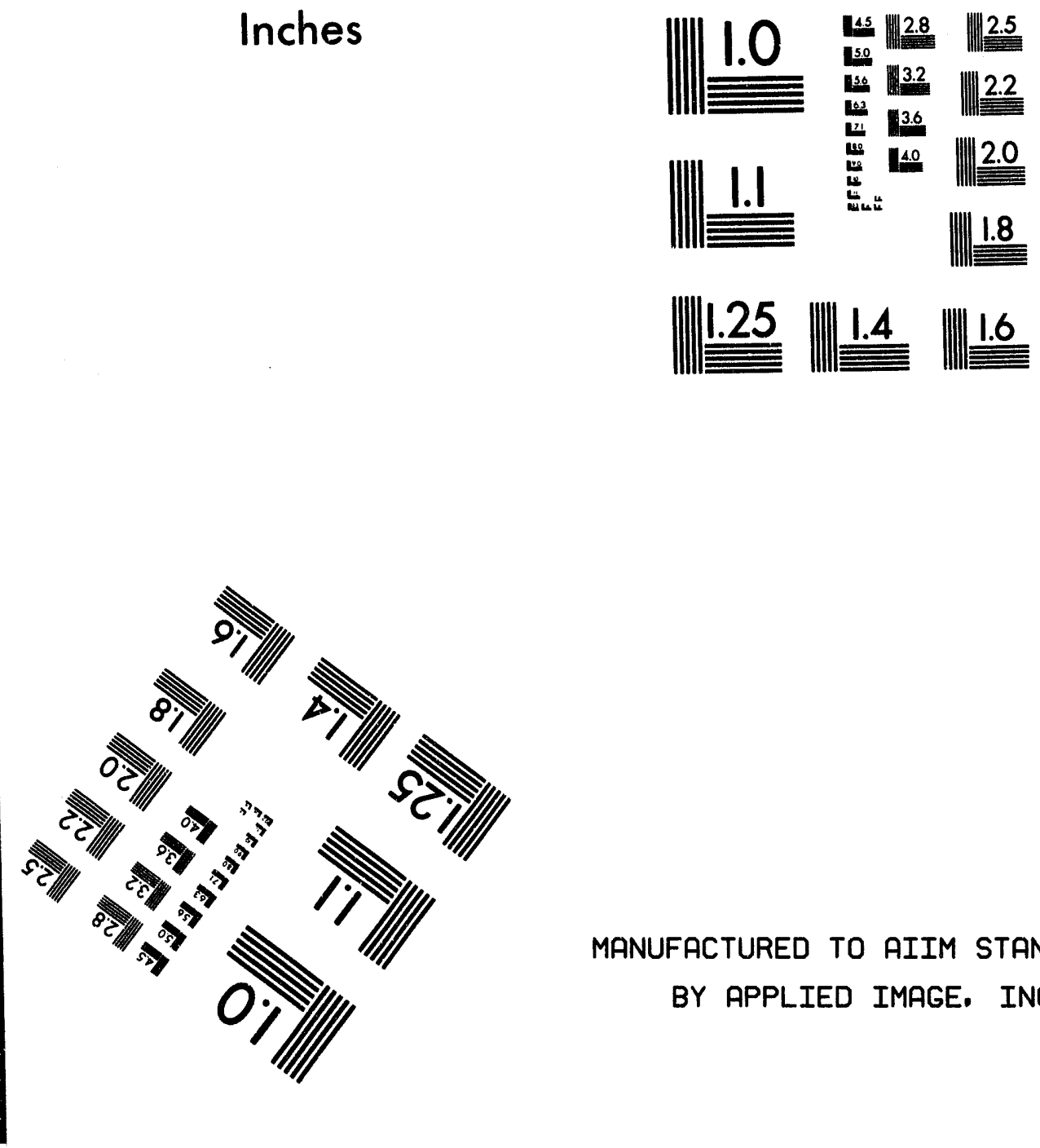

MANUFACTURED TO AIIM STANDARDS BY APPLIED IMAGE. INC.

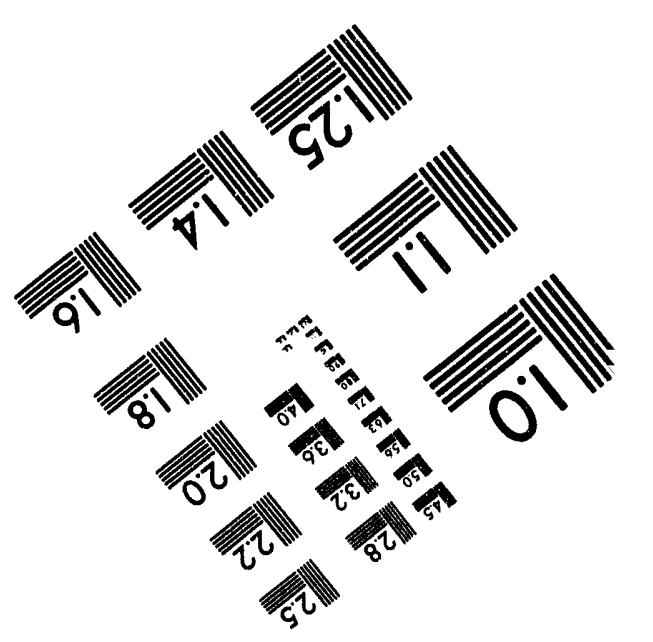



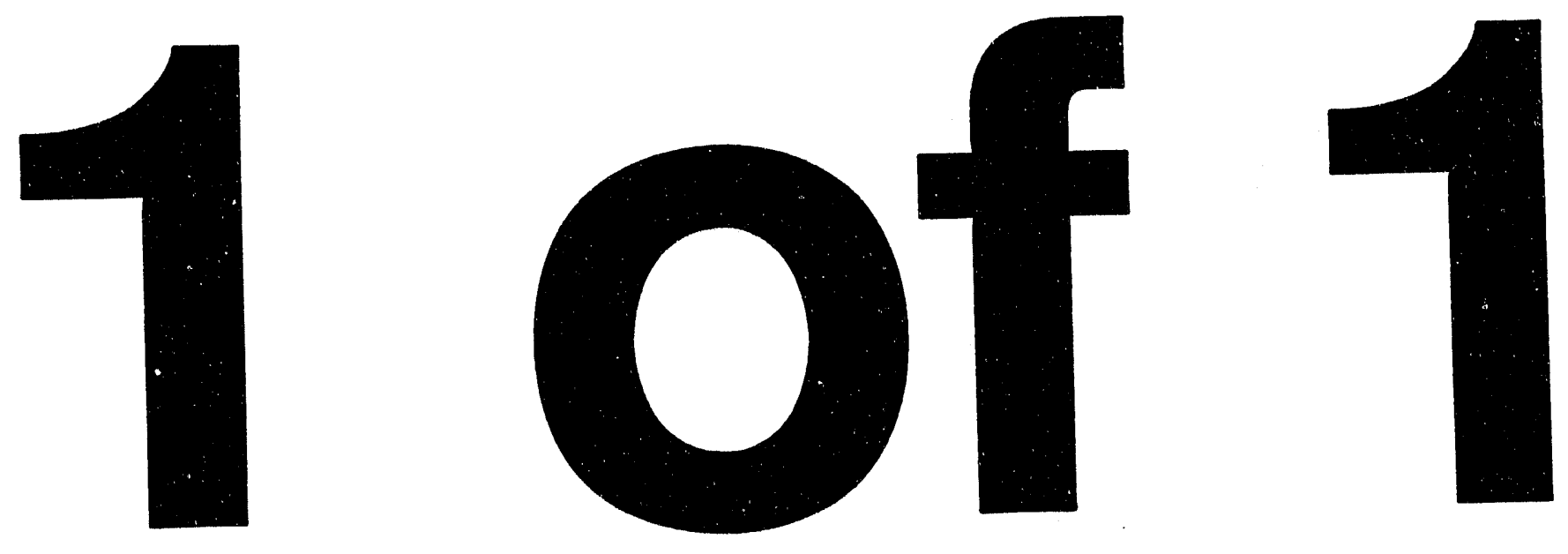


\section{International Energy Outlook}

1994

\section{July 1994}

\section{Energy Information Administration}

Office of Integrated Analysis and Forecasting

U.S. Department of Energy

Washington, DC 20585

This report was prepared by the Energy Information Administration, the independent statistical and analytical agency within the Department of Energy. The information contained herein should not be construed as advocating or reflecting any policy position of the Department of Energy or of any other organization. 
The International Energy Outlook is prepared by the Energy Information Administration (EIA). General questions concerning the contents of the report should be referred to Mary J. Hutzler (202/586-2222), Director, Office of Integrated Analysis and Forecasting; Mark E. Rodekohr (202/586-1130), Director, Energy Demand

\section{Contacts}

and Integration Division; or Gerald E. Peabody (202/ 586-1458), Chief, International, Economic, and Integrated Forecasting Branch. Specific questions about the report should be referred to A. David Sandoval (202/ 586-6581) or the following analysts:

World Oil Markets ............ G. Daniel Butler

Natural Gas . . . . . . . . . . . E Eric Grim

(202/586-9503)

Coal ................... Robert Manicke

$(202 / 586-6572)$

Melinda Hobbs

(202/586-2157)

(202/586-0012)

Nuclear

Mark Gielecki

$(202 / 254-5320)$

Laura Church

(202/586-1494)

Renewable Energy ............ Linda E. Doman

(202/586-1041)

Economic Growth ............. A. David Sandoval

(202/586-6581)

Environment .............. Laura L. Knight

(202/586-2313) 


\section{Contents}

Page

Highlights $\ldots \ldots \ldots \ldots \ldots \ldots \ldots \ldots \ldots \ldots \ldots \ldots \ldots \ldots \ldots$

Energy Consumption Totals $\ldots \ldots \ldots \ldots \ldots \ldots \ldots \ldots \ldots$

The World Oil Market $\ldots \ldots \ldots \ldots \ldots \ldots \ldots \ldots \ldots \ldots \ldots \ldots \ldots$

World Oil Prices $\ldots \ldots \ldots \ldots \ldots \ldots \ldots \ldots \ldots \ldots \ldots \ldots \ldots \ldots$

World Oil Consumption $\ldots \ldots \ldots \ldots \ldots \ldots \ldots \ldots \ldots \ldots$

Non-OPEC Oil Production Potential $\ldots \ldots \ldots \ldots \ldots \ldots \ldots \ldots 17$

OPEC Oil Production Capacity $\ldots \ldots \ldots \ldots \ldots \ldots \ldots \ldots \ldots$

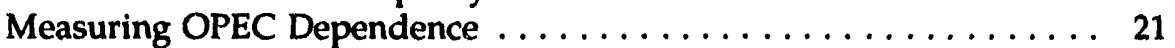

The Impact of an Oil Supply Disruption $\ldots \ldots \ldots \ldots \ldots \ldots \ldots 22$

Natural Gas ............................ 25

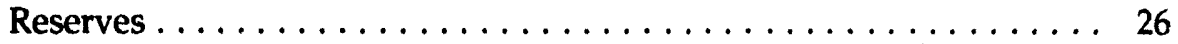

Pipeline and Liquefied Natural Gas Trade $\ldots \ldots \ldots \ldots \ldots \ldots \ldots 26$

Regional Prospects ....................... 27

Coal $\ldots \ldots \ldots \ldots \ldots \ldots \ldots \ldots \ldots \ldots \ldots \ldots \ldots \ldots \ldots \ldots \ldots \ldots \ldots \ldots$

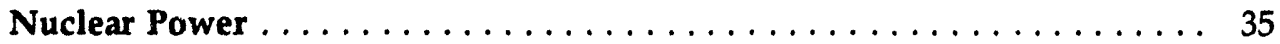

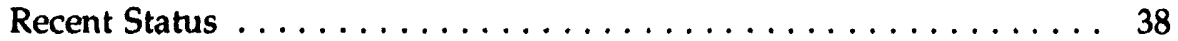

Nuclear Plant Lifetimes and Performance $\ldots \ldots \ldots \ldots \ldots \ldots \ldots, 38$

Globalization of Industry $\ldots \ldots \ldots \ldots \ldots \ldots \ldots \ldots \ldots \ldots \ldots$

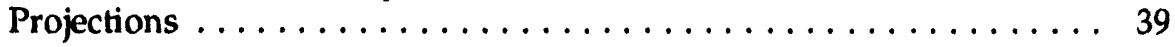

Hydroelectric and Other Renewable Energy . . . . . . . . . . . 41

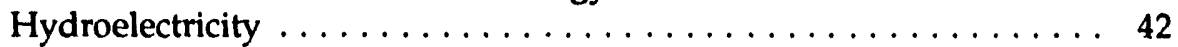

Current Status $\ldots \ldots \ldots \ldots \ldots \ldots \ldots \ldots \ldots \ldots \ldots \ldots \ldots \ldots$

Financial Concerns ..................... 43

Environmental Issues $\ldots \ldots \ldots \ldots \ldots \ldots \ldots \ldots \ldots \ldots \ldots \ldots, 43$

Geothermal Energy $\ldots \ldots \ldots \ldots \ldots \ldots \ldots \ldots \ldots \ldots \ldots \ldots$

Other Renewable Energy Sources . . . . . . . . . . . . . 45

Environmental Considerations $\ldots \ldots \ldots \ldots \ldots \ldots \ldots \ldots \ldots \ldots$

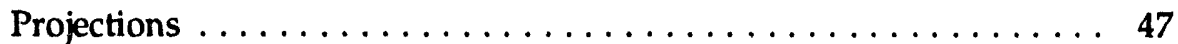

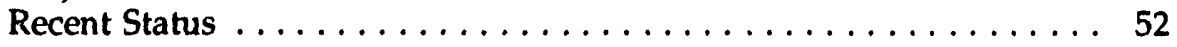

Comparison of International Energy Projections $\ldots \ldots \ldots \ldots \ldots \ldots$

World Energy Consumption $\ldots \ldots \ldots \ldots \ldots \ldots \ldots \ldots \ldots \ldots$

World Oil Market $\ldots \ldots \ldots \ldots \ldots \ldots \ldots \ldots \ldots \ldots \ldots \ldots$

References $\ldots \ldots \ldots \ldots \ldots \ldots \ldots \ldots \ldots \ldots \ldots \ldots \ldots \ldots \ldots \ldots$

Appendixes

A. World Energy Consumption Tables $\ldots \ldots \ldots \ldots \ldots \ldots \ldots \ldots \ldots 65$

B. Analytical Methods ...................... 75 
1. Annual Growth Rates of Real Gross Domestic Product (GDP), Base Case ............................. 7

2. World Oil Prices, $1979-2010 \ldots \ldots \ldots \ldots \ldots \ldots \ldots \ldots \ldots \ldots \ldots 11$

3. World Oil Consumption and Production, Base Case $\ldots \ldots \ldots \ldots 13$

4. World Crude Oil Reserves . .................... 14

5. Gasoline Prices and Tax Component in the OECD, $1992 \ldots \ldots \ldots \ldots 17$

6. World Oil Production Capacity Assumptions $\ldots \ldots \ldots \ldots \ldots \ldots 20$

7. World Natural Gas Reserves ..................... 26

8. World Coal Flows by Importing and Exporting Regions, Base Case . . . 33

9. Historical and Projected Operable Nuclear Capacities . . . . . . . . 37

10. World Electricity Installed Capacity for Hydroelectricity and Other Renewable Sources, $1992 \ldots \ldots \ldots \ldots \ldots \ldots \ldots \ldots \ldots . \ldots 44$

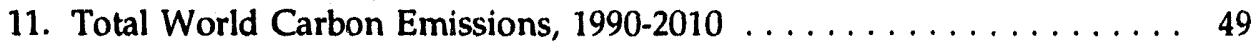

12. Carbon Emissions from Oil, $1990-2010 \ldots \ldots \ldots \ldots \ldots \ldots \ldots \ldots$

13. Carbon Emissions from Natural Gas, $1990-2010 \ldots \ldots \ldots \ldots \ldots . \ldots .53$

14. Carbon Emissions from Coal, $1990-2010 \ldots \ldots \ldots \ldots \ldots \ldots$. . . . . . 54

15. Comparison of Energy Consumption by Type, $1990-2010$. . . . . . . 58

16. Comparison of Energy Consumption Growth Rates by Type, $1990-2010$. . . . . . . . . . . . . . . . . . . . . . . . . . . . . . 59

17. Average Annual Growth Rates in Energy Consumption by Region,

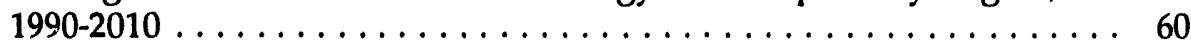

18. Economic Growth Assumptions by Region for Selected Studies, 1990-2010 . . . . . . . . . . . . . . . . . . . . . . . . . 61

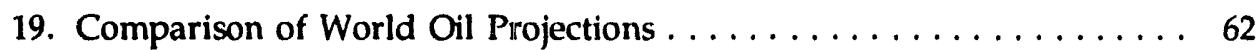

A1. World Energy Consumption by Country Group and Fuel Type, 1990-2010 . . . . . . . . . . . . . . . . . . . . . . . . . 65

A2. World Energy Consumption by Country Group, 1990-2010 . . . . . . 66

A3. World Oil Consumption by Country Group, 1990-2010 . . . . . . . . 67

A4. World Natural Gas Consumption by Country Group, 1990-2010 . . . 68

A5. World Coal Consumption by Country Group, 1990-2010 . . . . . . . 69

A6. World Nuclear Energy Consumption by Country Group, 1990-2010 . . 70

A7. World Hydroelectricity and Other Renewable Energy Consumption by Country Group, $1990-2010$. . . . . . . . . . . . . . . 71

A8. World Energy Consumption by Country Group and Fuel Type,

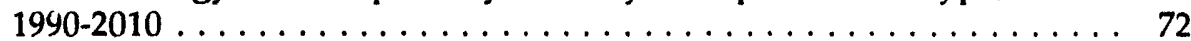

A9. World Energy Consumption by Country Group, $1990-2010$. . . . . . 73

B1. Average Annual Growth Rates in Real Gross Domestic Product (GDP) by Region, $1990-2010 \ldots \ldots \ldots \ldots \ldots \ldots \ldots \ldots \ldots \ldots \ldots$

B2. Average Annual Growth Rates in Oil Demand by Region, 1990-2010 . . 75

B3. Energy Intensity by Region, $1980-2010 \ldots \ldots \ldots \ldots \ldots \ldots \ldots$ 
1. Map of the Three Primary Country Groupings $\ldots \ldots \ldots \ldots$. . . . viii

2. Share of World Energy Consumption by Primary Energy Source, 1990-2010 . . . . . . . . . . . . . . . . . . . . . . . . 1

3. OPEC Oil Production as a Percentage of World Oil Consumption .... 1

4. World Oil Price Ranges, $1970-2010 \ldots \ldots \ldots \ldots \ldots \ldots \ldots \ldots . \ldots 2$

5. Global Energy Consumption by Primary Energy Source, 1990-2010 . . . 2

6. Comparative Projections of Growth in Energy Consumption for the Three Major Country Groupings, 1990-2010 (with Percentage Increases over 1990) ............... 3

7. Comparison of Carbon Emissions from the Three Major Country Groupings, 1990-2010 (with Percentage Increases over 1990) ....... 3

8. Total World Energy Consumption, $1980-2010 \ldots \ldots \ldots \ldots \ldots \ldots$

9. World Energy Consumption by Major Country Groupings,

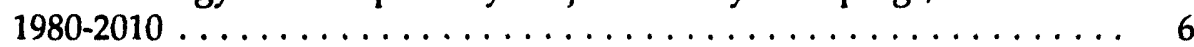

10. Energy Intensity (Energy Consumption per Dollar of Real GDP), 1980-2010 ............................... 6

11. World Energy Consumption by Type, $1980-2010 \ldots \ldots \ldots \ldots \ldots .8$

12. Share of Eurasia Energy Consumption by Type, 1990-2010 . . . . . . 8

13. OPEC and Persian Gulf Oil Production as a Percentage

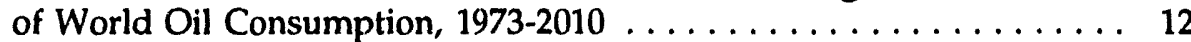

14. World Oil Reserves .......................... 15

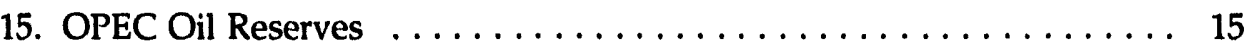

16. World Oil Consumption, $1980-2010 \ldots \ldots \ldots \ldots \ldots \ldots \ldots \ldots$

17. World Oil Consumption by Major Country Groupings, 1980-2010 . . . 16

18. Share of Oil Consumption by Major Country Groupings, 1980-2010 _. 16

19. Oil Consumption as a Percentage of Total Energy Consumption,

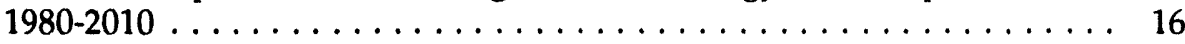

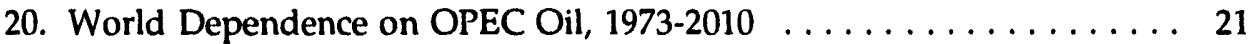

21. Price Impacts of an Oil Supply Disruption, $2000 \ldots \ldots \ldots \ldots \ldots .23$

22. Total World Natural Gas Consumption, $1980-2010 \ldots \ldots \ldots \ldots \ldots .25$

23. World Natural Gas Consumption by Major Country Groupings, 1980-2010 . . . . . . . . . . . . . . . . . . . . . . . . . . 25

24. Share of Natural Gas Consumption by Major Country Groupings,

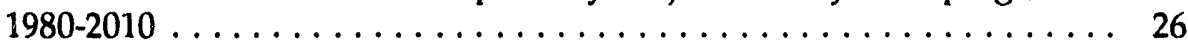

25. Natural Gas Reserves ......................... 26

26. Natural Gas Consumption as a Percentage of Total Energy

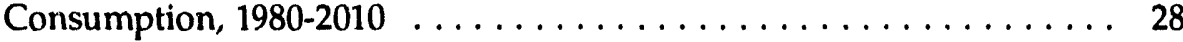

27. Total World Coal Consumption, $1980-2010 \ldots \ldots \ldots \ldots \ldots \ldots \ldots . . \ldots 31$

28. World Coal Consumption by Major Country Groupings, 1980-2010 . . 32 
29. Share of Coal Consumption by Major Country Groupings,

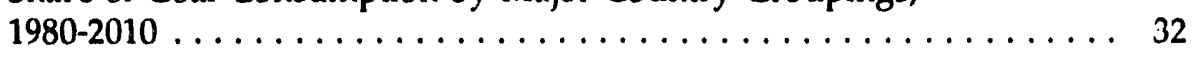

30. Coal Consumption as a Percentage of Total Energy Consumption,

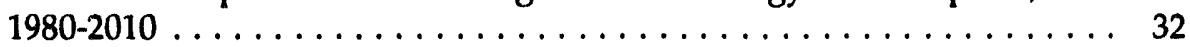

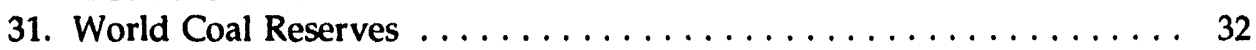

32. World Coal Trade, $1980-2010 \ldots \ldots \ldots \ldots \ldots \ldots \ldots \ldots$

33. Operable and Projected Nuclear Capacity in Various Regions, 1992, 2000, and 2010 (Lower Reference Case) .

34. Hydroelectricity and Other Renewable Energy Consumption as a Percentage of Total Energy Consumption, 1980-2010 . . . . . . 41

35. World Consumption of Hydroelectricity and Other Renewable Energy, 1980-2010 . . . . . . . . . . . . . . . . . . . . . . . . . . . . . . . . .

36. Share of Hydroelectricity and Other Renewable Energy Consumption by Major Country Groupings, $1980-2010$. . . . . . . . . . . 42

37. Consumption of Hydroelectricity and Other Renewable Energy by Major Country Groupings, $1980-2010 \ldots \ldots \ldots \ldots \ldots \ldots \ldots 42$

38. World Carbon Emissions by Fuel Type, 1990-2010 . . . . . . . . . . 47

39. World Trends: Economic Growth, Energy Consumption, and Carbon Emissions, $1990-2010 \ldots \ldots \ldots \ldots \ldots \ldots \ldots \ldots \ldots$

40. World Carbon Emissions by Region, $1990-2010 \ldots \ldots \ldots \ldots \ldots \ldots 48$

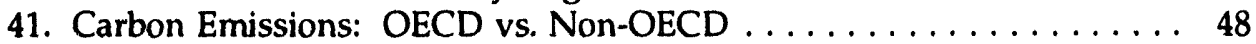

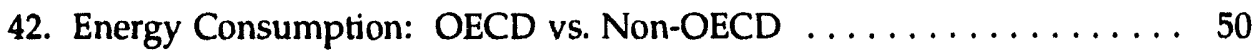

43. Economic Development and World Fossil Fuel Consumption . . . . 50

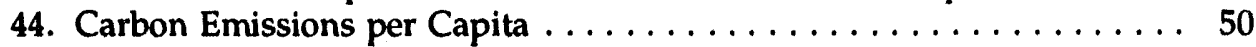

45. G-7 Energy Consumption by Fuel Type $\ldots \ldots \ldots \ldots \ldots \ldots \ldots \ldots 50$

46. Population, Economic Growth, Energy Consumption, and Carbon Emissions . ........................ 52

47. Economic Development and National Energy Use Patterns, 2010 . . . 52

B1. OPEC Oil Production, $1970-2010 \ldots \ldots \ldots \ldots \ldots \ldots \ldots \ldots \ldots$

B2. Non-OPEC Oil Production, $1970-2010 \ldots \ldots \ldots \ldots \ldots \ldots \ldots$

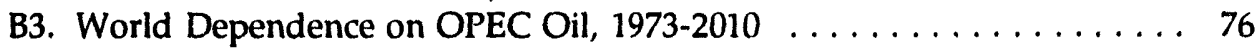




\section{Preface}

\section{Consistent with the Annual Energy Outlook 1994, energy projections are made to 2010 for various country groupings.}

The International Energy Outlook 1994 (IEO94) presents an assessment by the Energy Information Administration (EIA) of the outlook for international energy markets between 1990 and 2010. The report is provided as a statistical service to assist energy managers and analysts, both in government and in the private sector. These forecasts are used by international agencies, Federal and State governments, trade associations, and other planners and decisionmakers. They are published pursuant to the Department of Energy Organization Act of 1977 (Public Law 95-91), Section 205(c). The IEO94 projections are based on U.S. and foreign government policies in effect on October 1, 1993 - which means that provisions of the Climate Change Action Plan unveiled by the Administration in mid-October are not reflected in the U.S. projections.

This document is an extension of EIA's Anmual Energy Outlook 1994 (AEO94), which was prepared using the new National Energy Modeling System (NEMS). The U.S. projections, Base Case world oil balances, and projections of world oil prices are identical in both.

The IEO94 displays its projections by various country groupings and subgroups. Designated groupings reflect the end of the Cold War and are defined in Figure 1.

Base Case projections of foreign natural gas, coal, other energy, and total energy consumption were prepared using the World Energy Projection System (WEPS). Other energy consists of hydroelectricity, geothermal, solar, biomass, wind, and other renewable sources. Base Case projections of foreign oil production and consumption were prepared using the Oil Market Simulation (OMS) Model, a component of NEMS.

Base Case projections for nuclear consumption were derived from the International Nuclear Model. The nuclear capacity projections were developed using two methods. One bases projections on knowledge of a country's nuclear program. The other uses the World Integrated Nuclear Evaluation System (WINES)-a demand-driven model. In addition, the NEMS Coal Export Submodule (CES) was used to derive flows in international coal trade.

Rather than present a set of alternative scenarios, as does the $A E O 94$, this report presents a Base Case and accompanies it with a range of sensitivity for each of the major fuel areas. Projections from the AEO94 and the International Energy Agency's World Energy Outlook, 1993, represent the oil consumption range. Two consumption cases derived from International Nuclear Model projections represent the nuclear range. The sensitivity range for total energy is calculated by altering assumptions about economic growth and energy intensity. Sensitivity ranges for natural gas, coal, and other energy are calculated by altering assumptions about economic growth, energy intensity, the demand for oil, and the demand for nuclear energy (see Appendix B). 
Organization for Economic Cooperation and Development (OECD): Australia, Austria, Belgium, Canada, Denmark, Finland, France, Germany, Greece, Iceland, Ireland, Italy, Japan, Luxembourg, the Netherlands, New Zealand, Norway, Portugal, Spain, Sweden, Switzerland, Turkey, the United Kingdom, and the United States. (Contains 15 percent of 1994 world population.) Note: Although not reflected in the projections, Mexico joined the OECD on May 18, 1994.
Eurasia: China, the former Soviet Union (FSU), and Eastern Europe. (Contains 30 percent of 1994 world population.)

Rest of World (ROW): All countries other than OECD and Eurasia. Thus, although this grouping does not include China (which is occasionally treated separately in this report), ROW is generally synonymous with "Developing Countries" worldwide. (Contains 55 percent of 1994 world population.)

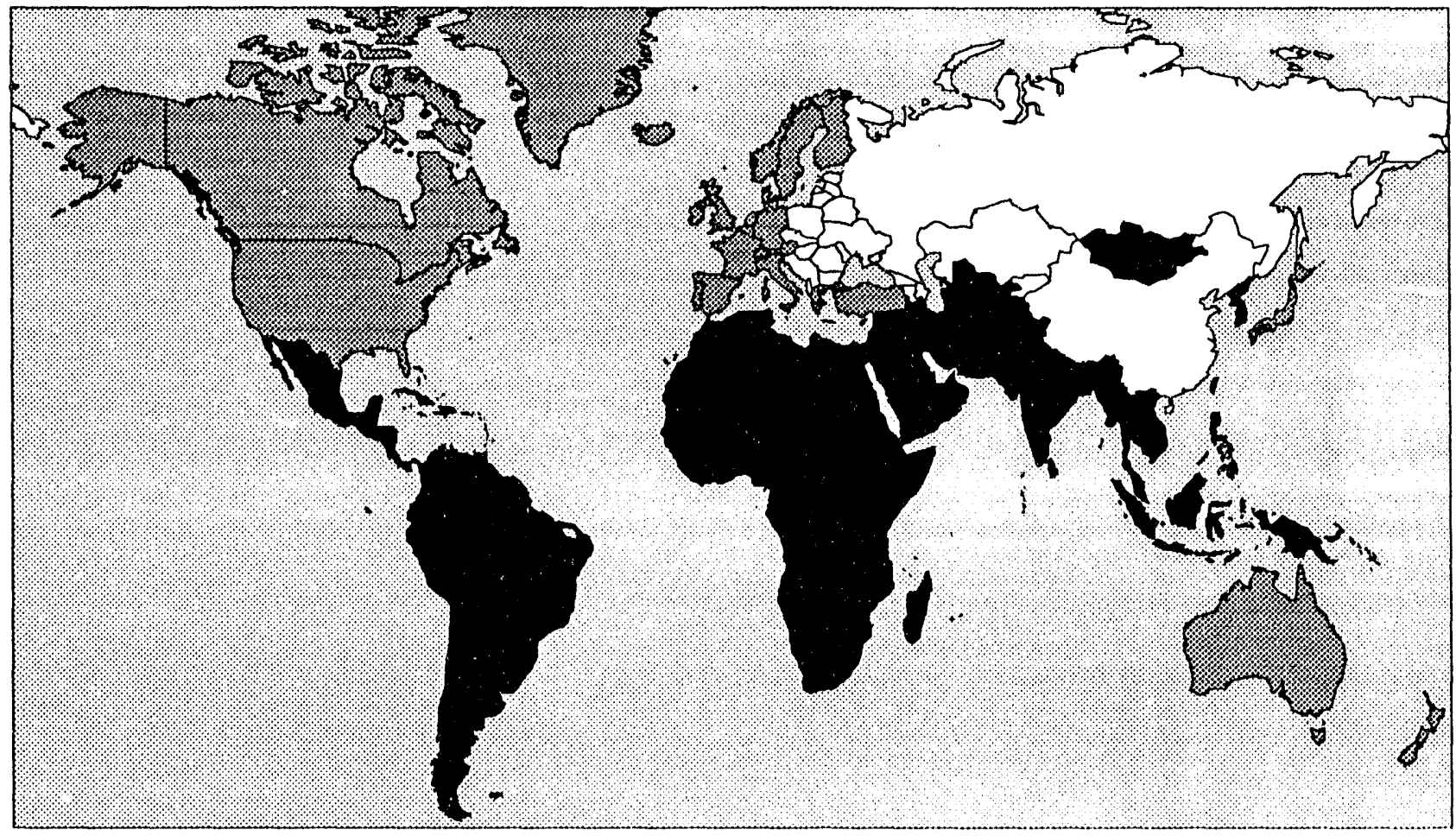

\section{Definitions of Country Subgroups, as Used in This Report}

- Eastern Europe: Albania, Bulgaria, former Czechoslovakia, Hungary, Poland, Romania, and former Yugoslavia.

- Former Soviet Union (FSU): The Baltic States of Estonia, Latvia, and Lithuania, as well as Armenia, Azerbaijan, Belarus, Georgia, Kazakhstan, Kyrgyzstan, Moldova, Russia, Tajikistan, Turkmenistan, Ukraine, and Uzbekistan.

- Pacific Rim Developing Countries: Hong Kong, Indonesia, Malaysia, Philippines, Singapore, South Korea, Taiwan, and Thailand.
- Organization of Petroleum Exporting Countries (OPEC): Algeria, Gabon, Indonesia, Iran, Iraq, Kuwait, Libya, Nigeria, Qatar, Saudi Arabia, the United Arab Emirates, and Venezuela.

- Middle East: Bahrain, Cyprus, Iran, Iraq, Israel, Jordan, Kuwait, Lebanon, Oman, Qatar, Saudi Arabia, Syria, the United Arab Emirates, and Yemen.

- Persian Gulf: Bahrain, Iran, Iraq, Kuwait, Qatar, Saudi Arabia, and the United Arab Emirates. 


\section{Highlights}

\section{Oil's market share should dip, but will remain dominant, as nations progress unevenly toward goals of energy security, economic growth, and clean environment.}

World energy consumption is projected to increase by about 1.6 percent per year between 1990 and 2010 . The need for secure energy supplies will continue to influence energy activities throughout the world. Reliable energy supplies are needed to spur economic growth and raise living standards. A major challenge will be to achieve economic objectives with a clean environment.

Oil is expected to continue to be the world's major energy source during this time, but it will represent a smaller share of all energy consumed-declining from about 39 percent of the total in 1990 to about 37 percent in 2010 (Figure 2). Coal's share of consumption will also decline slightly, while the shares for natural gas and other energy rise. (Other energy consists of hydroelectricity, geothermal, solar, wind, biomass, and other renewable sources.)

Despite efforts by countries of the Organization for Economic Cooperation and Development (OECD) and others to reduce dependence on oil from the Organization of Petroleum Exporting Countries (OPEC), the

Figure 2. Share of World Energy Consumption by Primary Energy Source, 1990-2010

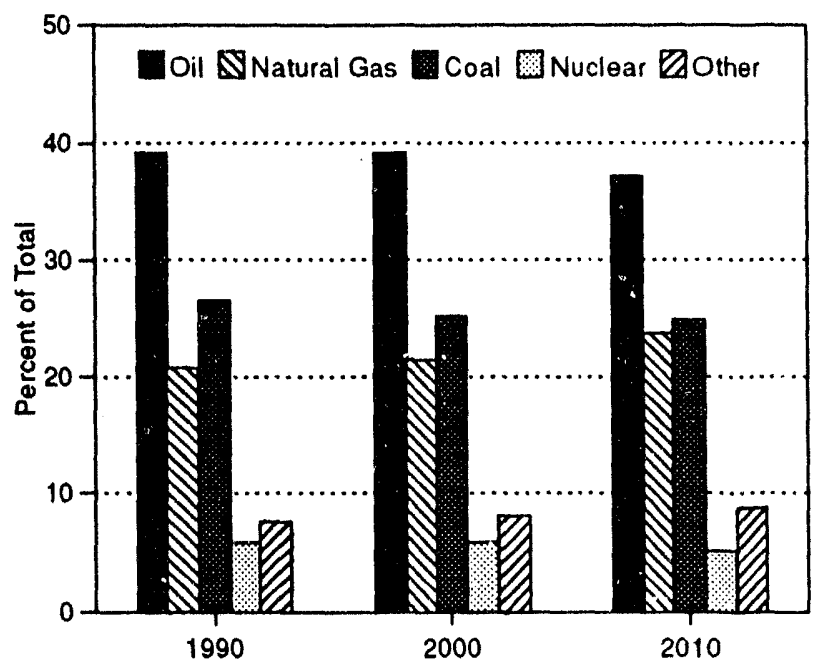

Source: Derived from Table A1.
OPEC share of world oil supplies-about 40 percent in 1992 -could easily reach 50 percent by 2010 (Figure 3). Prospects for oil production in the former Soviet Union (FSU), a major source outside the Middle East, are highly uncertain. Crude oil production there has fallen from a high of 12 million barrels per day in 1983 to a low of 7 million barrels per day by the end of 1993. Oil production outside OPEC and the FSU is projected to peak by 2000 , while world demand continues to grow. World oil prices are thus expected to rise moderately in real terms, primarily after 2000 (Figure 4).

Efforts to enhance energy security through diversification are expected to favor natural gas as an energy source. World wide consumption of natural gas (which in many instances can be substituted for oil products) is projected to grow much faster than oil consumption between 1990 and 2010 -about 2.3 percent per year for natural gas, compared to 1.3 percent for oil (Figure 5). Natural gas has the further advantage of burning more cleanly than either oil or coal.

Figure 3. OPEC OII Production as a Percentage of World Oil Consumption

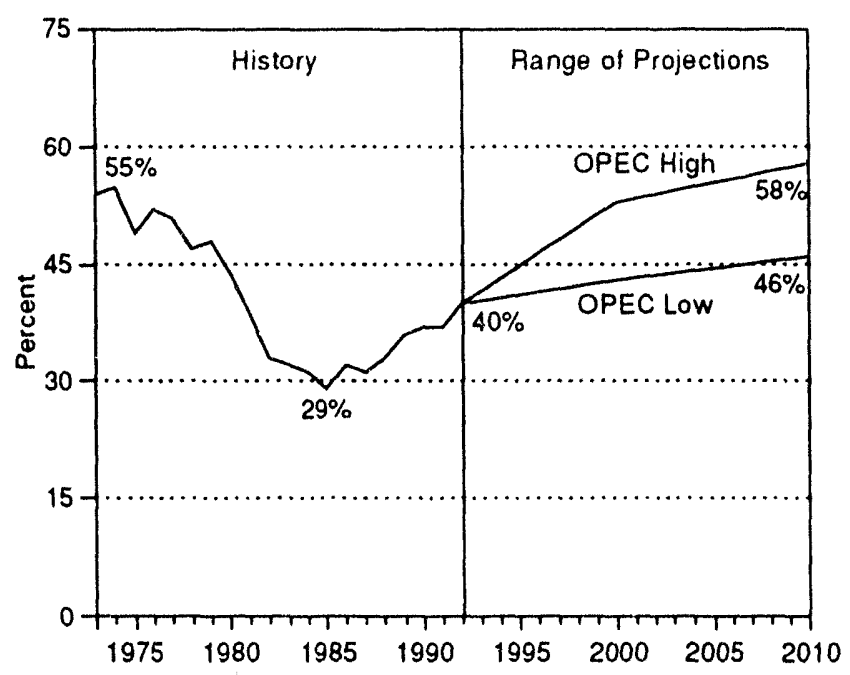

Sources: See sources for Figure 13. 
Figure 4. World OII Price Ranges, 1970-2010

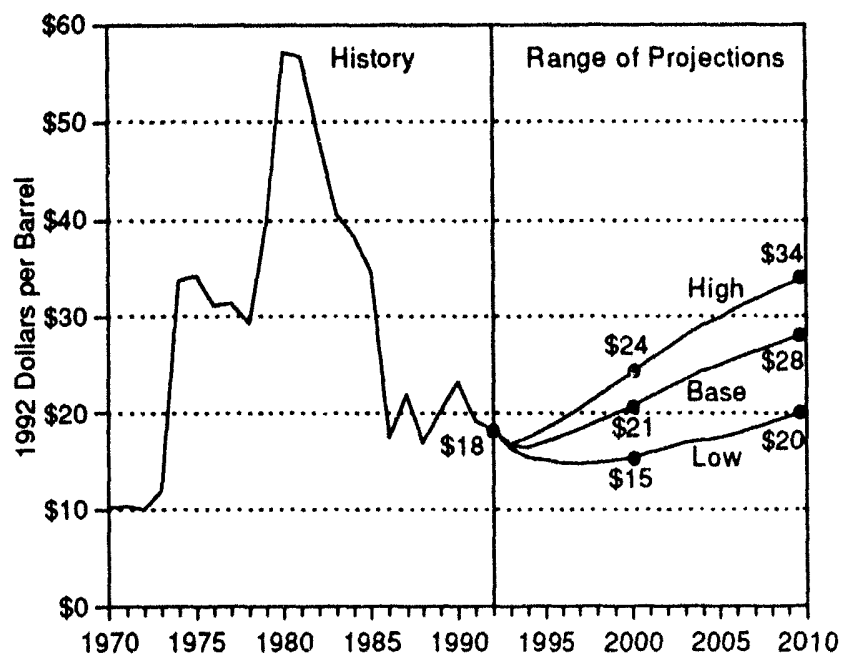

Sources: See sources for Table 2.

Coal is expected to continue to be the second largest energy source in the world through the year 2010 (Figure 5); but its use is projected to grow at the relatively slow rate of 1.3 percent per year over this period. The demand for this fuel is primarily for "steam coal" (as distinguished from "metallurgical coal" used in steelmaking), so the rise in global totals is tied closely to the demand for electricity. Between now and 2010, various types of "clean coal technology" - which remove sulfur and nitrogen oxides from the emissions of coal-burning equipment-face environmental evaluation and tests of the marketplace. This report's outlook for coal assumes that policies with respect to global warming and other environmental issues are those that were in place as of October 1993. Changes in those policies, such as those outlined in the U.S. Climate Change Action Plan, could alter coal-use patterns substantially.

World use of nuclear energy is projected to grow by about 1 percent per year between 1990 and 2010, the slowest rate of any major energy source (Figure 5). Concerns over costs, radioactive waste, plant safety, and nuclear proliferation will probably continue to constrain this industry's overall growth. However, with few indigenous energy resources of their own, France, Japan, and South Korea are expected to bolster energy security by building new nuclear capacity at a higher rate than elsewhere in the wurld. In Japan and South Korea, some new power plants will use advanced U.S. designs (or modifications of those designs), for which no orders have yet been placed in this country.

Consumption of hydroelectric and other renewable energy taken together is projected to grow by about 2.4 percent per year-increasing the share of total energy
Figure 5. Global Energy Consumption by Primary Energy Source, 1990-2010

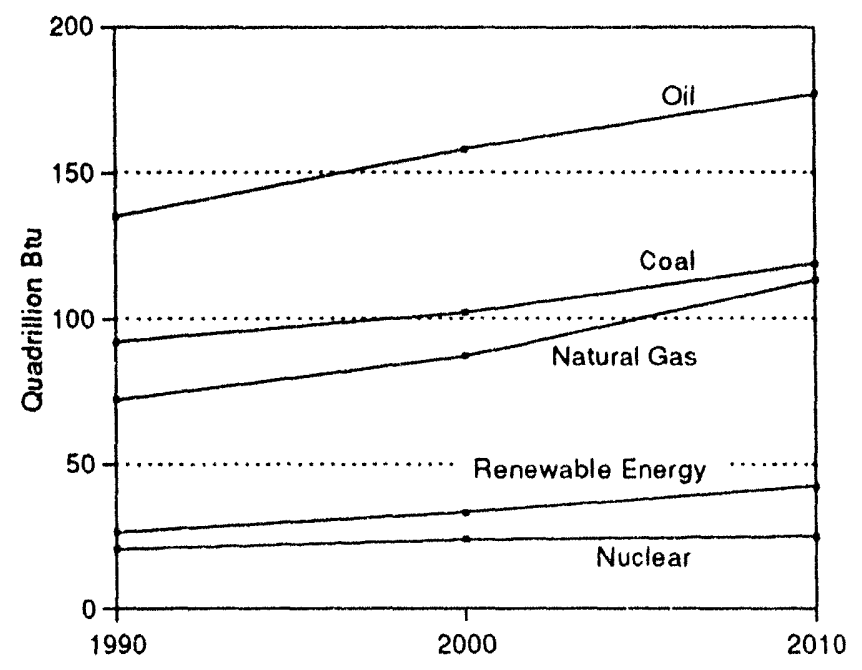

Source: Table A1.

consumption provided by these sources from about 7.6 percent in 1990 to about 8.8 percent by 2010 . Growing demarids for electric power, particularly among developing countries, are expected to help renewable energy grow faster than any other energy source between 1990 and 2010 (Figure 5).

Energy consumption will fuel worldwide economic growth, assumed to average about 2.7 percent per year between 1990 and 2010 (as measured by a rise in real gross domestic product, or GDP). Substantial variations in different areas of the world underlie the aggregate projections of economic development and energy consumption.

The OECD countries are expected to remain the largest consumer among the three major energy-consuming blocs considered in the analysis (Figure 6), although the rate at which its energy use grows (an average of 1.4 percent per year between 1990 and 2010), may be only about half as fast as that for the developing countries. This conjecture results largely from the fact that the OECD countries are already more mature economically and thus start the period from a higher standard of living. In addition, OECD countries have become acutely aware of the problem of energy vulnerability since the oil price shocks of the 1970's. Actions taken to address this problem have helped to curb the rate of growth of energy consumption in the recent past and are expected to affect future consumption patterns as well.

Faster growth in energy use by countries in the rest of the world (ROW) taken together (about 2.7 percent per year between 1990 and 2010) can be expected from 
Figure 6. Comparatlve Projectlons of Growth in Energy Consumption for the Three Major Country Groupings, 1990-2010 (with Percentage Increases over 1990)

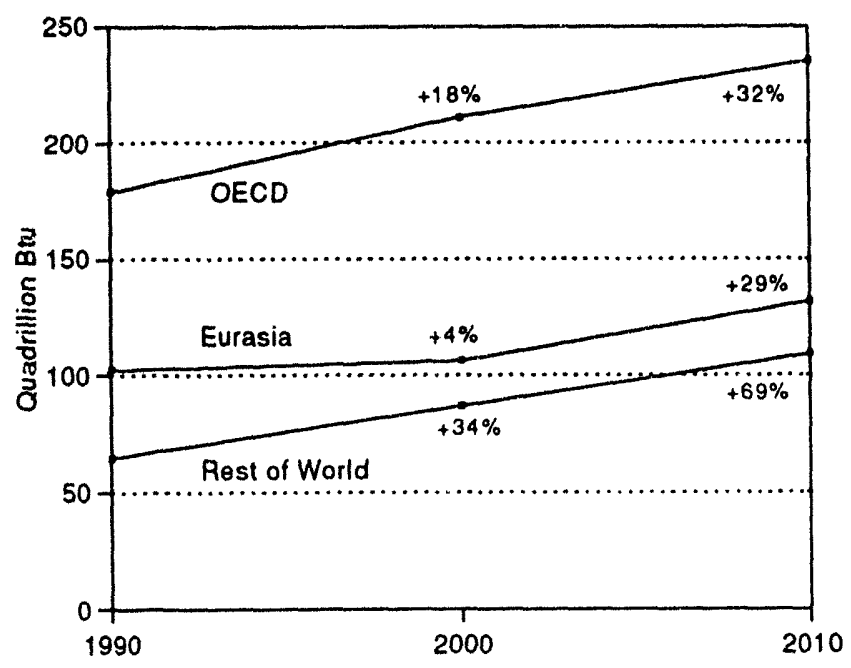

Source: Table A1.

efforts to increase the standard of living of fast-growing populations through modernization and industrialization. The GDP of the ROW countries is assumed to grow on average by about 4.2 percent per year between 1990 and 2010, as compared with about 2.4 percent in the OECD and about 2.3 percent in Eurasia (China, the FSU, and Eastern Europe). Within the ROW grouping, however, great variations can also be foreseen. For instance, the Pacific Rim countries (such as South Korea and Taiwan) are frequently referred to as "newly industrialized countries" rather than developing countries.

The economic and political revolutions occurring in Eurasia make energy prospects in this region highly uncertain; and the constituents of this grouping are far from homogeneous. Although energy consumption is projected to grow by about 1.3 percent per year for the country grouping as a whole between 1990 and 2010 (Figure 6), the FSU and Eastern Europe could actually be using less energy in the year 2000 than they did in 1990, because of their current economic troubles. In contrast, China could experience the world's fastest growth in energy consumption over the next two decades.

China has pursued aggressive policies to encourage economic development. In its efforts to modernize, this country is continuing to shift economic decisionmaking away from central planners and into the marketplace.

\section{Figure 7. Comparison of Carbon Emissions from the Three Major Country Groupings, 1990-2010 (with Percentage Increases over 1990)}

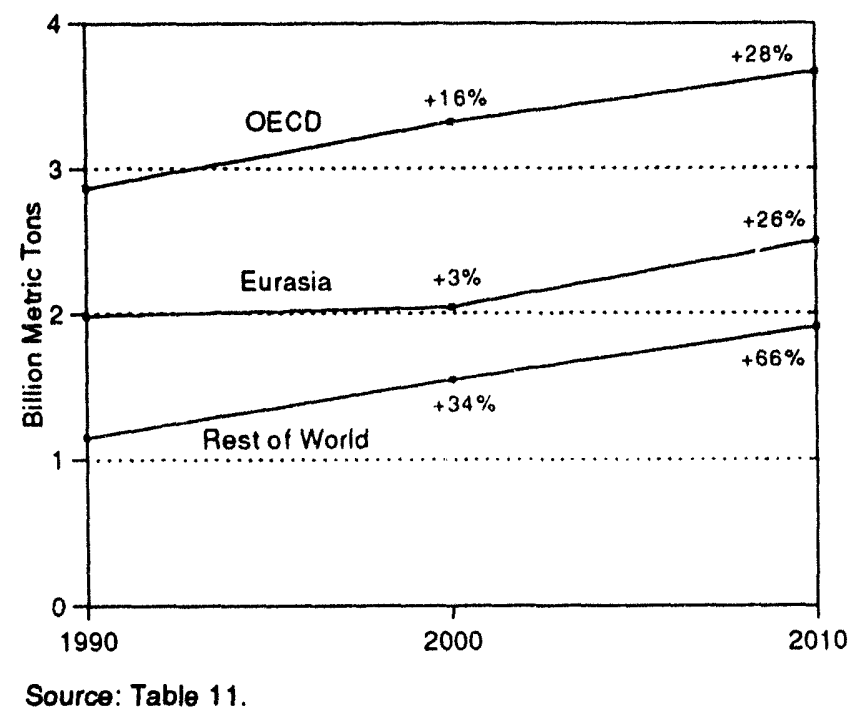

The result has been a spectacular spurt of economic growth that should continue through the year 2010, although probably at a slower pace than in recent years. Meanwhile, the economies of Eastern Europe and the FSU have experienced a virtual collapse since 1990; but the energy projections presented in this report assume that efforts at institutional reforms will eventually be successful there and that more normal economic growth will resume after a period of decline.

Individual countries of the OECD have a considerable advantage over the Eurasia countries and the ROW countries in terms of the financial and technological resources they can muster to achieve the dual goals of economic prosperity and a cleaner environment. Thus, in respect to one particular envirormental concern-the possibility of global climate change due to the "greenhouse effect" brought about by increased emissions of certain gases-energy-related carbon emissions are likely to grow fastest of all in the developing countries, even though the OECD is expected to continue to be the largest producer of carbon emissions as a block (Figure 7). Overall, such carbon emissions are projected to grow worldwide by about 1.5 percent per year over these next two decades, although it is always possible that new policy initiatives would change this outlook substantially. For example, the United States announced a Climate Change Action Plan in October 1993, whose provisions are not reflected in the projections presented here. 


\title{
Energy Consumption Totals
}

\author{
China and other developing countries are expected to lead in expansion \\ of energy use while former Soviet Union lags and OECD's energy imports grow.
}

A major challenge facing all countries of the world over these next two decades will be to develop programs and policies that focus on reliable and affordable energy sources while producing sustainable economic growth and maintaining the integrity of the environment. The levels of economic growth, which is measured as the increase in real (adjusted for inflation) gross domestic product-GDP, will be a major factor determining the growth of energy consumption.

The global energy projections presented here are based on two key assumptions: (1) future economic growth and (2) the "energy intensity" of future economic activity (conventionally expressed as an index of total energy consumption divided by real GDP). These projections assume a worldwide economic growth rate of 2.4 percent per year between 1990 and 2000 , increasing to 3.1 percent during the succeeding decade (Table 1). Energy intensity is projected to continue an historic decline from 21.6 to 17.4 thousand Btu per 1985 GDP dollar between 1990 and 2010 (Appendix B, Table B3).

Projected ranges for world energy consumption are displayed in Figures 8 and 9. (Ranges are derived using the methodology described in Appendix B). A series of more detailed consumption tables (by individual energy sources for 1990, 1992, 2000, 2005 and 2010) is included as Appendix A-Tables A1 through A9.

The energy intensity of economic activity in the world as a whole is projected to decline steadily over the projection period (Figure 10). Defined as the ratio of total energy consumption to GDP, energy intensity worldwide will be influenced by factors such as technological advances, the sectoral mix of economic activity, energy prices, and the availability of financing to replace old capital stock (see box) [32, p. 23]. Besides raising world energy efficiency, improvements in technology-particularly in transportation and power generation-should help to restrain growth of energyrelated pollution. Within the developing countries that make up most of the world, however, efforts to reduce energy intensity may be limited by lack of financial
Figure 8. Total World Energy Consumption, 1980-2010

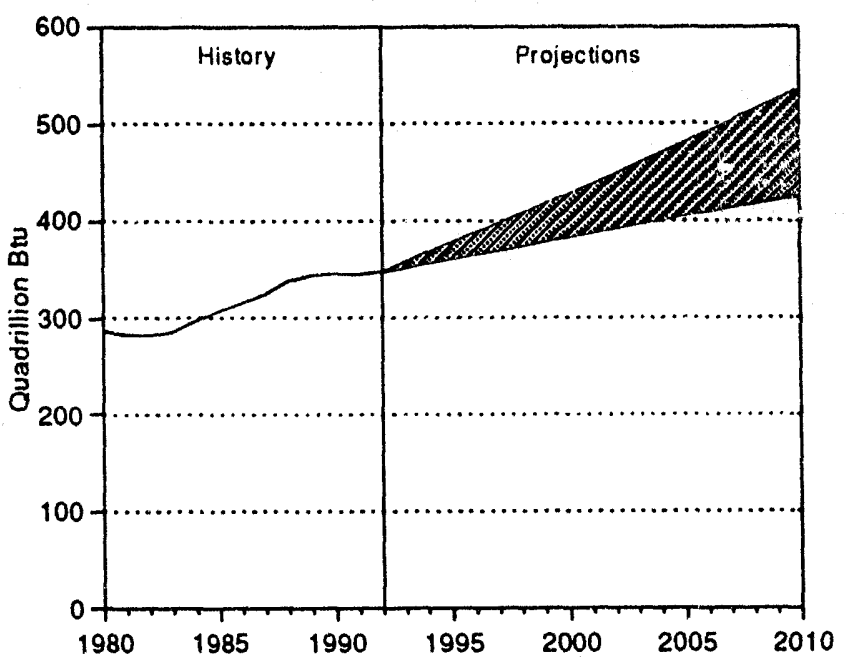

Sources: History: Energy Information Administration, International Energy Annual 1992, DOE/EIA.0219(92), Table A9 and related data base. Projections: Table A1.

resources and by the tendency to focus on resourcebased activities (such as petrochemicals in the Middle East) [32, p. 25].

Projections of economic growth show a considerable difference between the industrial countries of the Organization for Economic Cooperation and Development (OECD)-for which an average annual GDP increase of 2.4 percent between 1990 and 2010 is assumed-and the developing countries that constitute the "Rest of World" (ROW) category with an assumed growth rate of 4.2 percent per year (Table 1). However, projected economic growth rates differ within these country groups too-particularly within the ROW group. Generally lower oil price, during the late 1980's directly restrained GDP growth for many members of the Organization of Petroleum Exporting Countries (OPEC). Looking to the future, it is likely that some developing countries will remain poor while others (such as certain Pacific Rim nations) will achieve or 
Figure 9. World Energy Consumption by Major Country Grouplings, 1980-2010

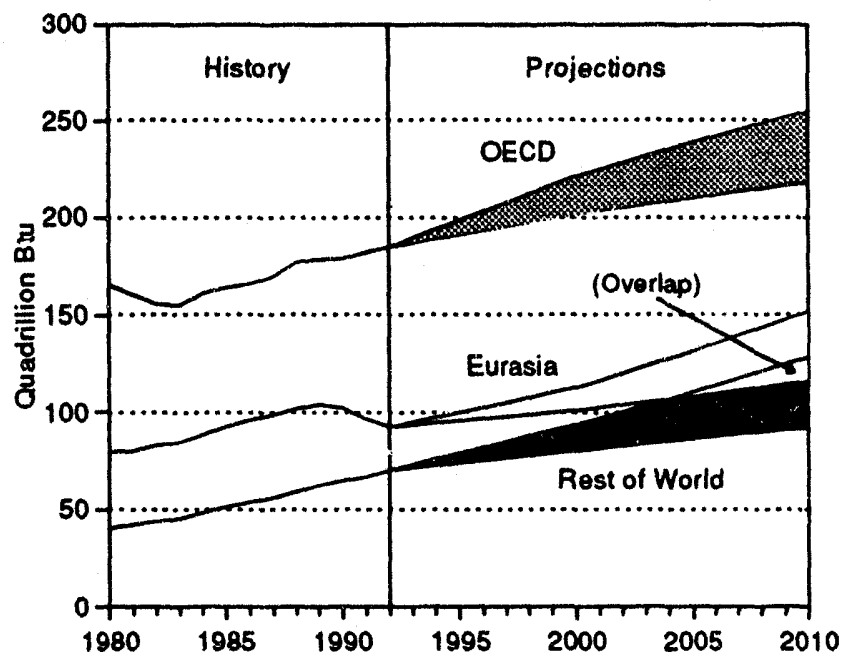

Sources: Hislory: Energy Information Administration, International Energy Annual 1992, DOE/EIA-0219(92), Table A9 and related data base. Projections: Table A2.
Figure 10. Energy Intensity (Energy Consumption per Dollar of Real GDP), 1980-2010

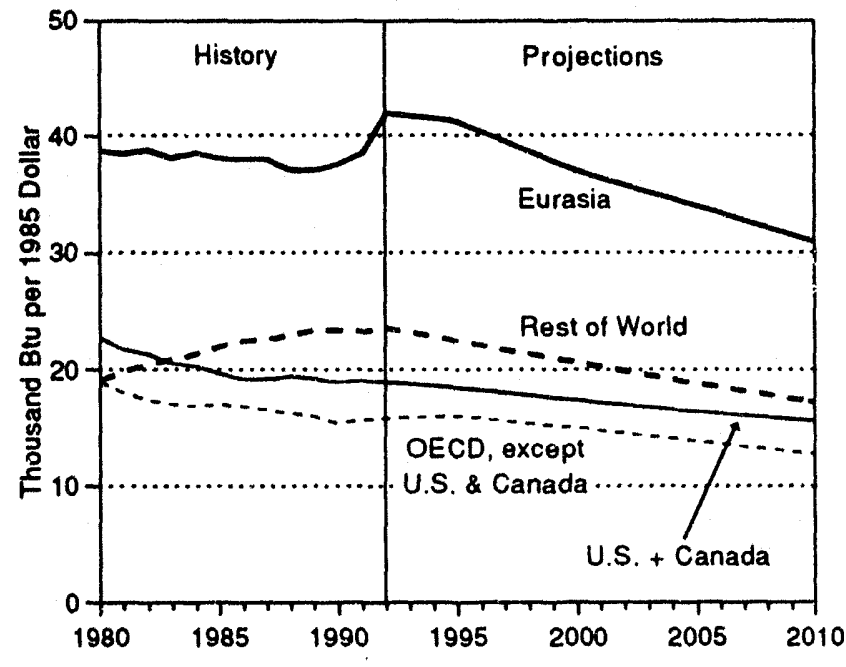

Sources: Hislory: The Wharton Econometric Forecasting Associales, World Economic Service and World Economic Service Historical Data 1993; and Energy Information Administration International Energy Annual 1992, DOE/ElA-0219(92), Table A9 and related data base. Projections: See Appendix Table B3.

\section{H.}

Whobent years, energy intensity (he ratio of total energy consumpion divided by real GDP) in the world has decined stighty while that in Eurasia has actually tisen since 1989 (Figure 10), However, this rise in the index of Burgsian energy intensity resultad primanily fom poltical and economic tumoil in the former Soviet Union (PSU)- where enery consumption has dedined every year since 1989 [11, p. 118], but GDP has declined even faster. Even though both economic activity and energy consumption in the FSU are projected to retum to more conventional paths bejond 1995, the FSU (and Burasia as a whole) will likely continue to be the world's most inefficient users of energy. This inefficiency is a legacy of a long historical period in Which domestic energy prices were substantialy below prices in the world markets, which resulted in the ceiclopment of on industral base that uses energy very ineffidently. There is, in fact, considerable room for Improvement, and any ise in energy efficiency would also help address the many serious environmental problems that exist there.

For most $O B C D$ countries, the pace of future gains in energy efficiency will likely be more difficult to achieve than in the past because many of the easy measures have already been undertaken. Nevertheless, energy Intensity will dedine in many devaloped coumtries as technological change continues to shift their economic structures away from energy intensive heavy manufacturing and towards less energy-intensive services and Wigh-tech industries.

Among the developing countries, policies aimed at improving the standard of living through increased economic activity could tend to increase the average energy intensity of world economic activity. Efforts at industrialization will continue, and newly industrialized countries will endeavor to expand their manufacturing base. Many manufacturing activities are highly energy intensive. Countries that pursue economic prosperity through the exploitation of natural resources (including the hydrocarbon reserves of OPEC) will find that this is usually a very energy intensive process as well. 
Table 1. Annual Growth Rates of Real Gross Domestic Product (GDP), Base Case (Percent)

\begin{tabular}{|c|c|c|c|c|c|c|}
\hline \multirow[b]{3}{*}{ Country/Region } & \multicolumn{6}{|c|}{ Average Annual GDP Growth Rates } \\
\hline & \multicolumn{3}{|c|}{ History } & \multicolumn{3}{|c|}{ Assumptions } \\
\hline & $1970-1980$ & $1980-1985$ & $1985-1990$ & $1990-2000$ & $2000-2010$ & $1990-2010$ \\
\hline World $\ldots \ldots \ldots \ldots \ldots \ldots \ldots$ & 3.6 & 2.5 & 3.1 & 2.4 & 3.1 & 2.7 \\
\hline Total OECD ............... & 3.1 & 2.4 & 3.2 & 2.2 & 2.5 & 2.4 \\
\hline United States $\ldots \ldots \ldots \ldots \ldots$ & 2.8 & 2.5 & 2.7 & 2.2 & 2.1 & 2.1 \\
\hline Canada $\ldots \ldots \ldots \ldots \ldots \ldots$ & 4.6 & 2.9 & 2.9 & 2.5 & 2.4 & 2.5 \\
\hline Japan $\ldots \ldots \ldots \ldots \ldots \ldots$ & 4.5 & 3.7 & 4.5 & 3.0 & 3.4 & 3.2 \\
\hline OECD Europe $\ldots \ldots \ldots \ldots$ & 3.0 & 1.6 & 3.2 & 1.8 & 2.6 & 2.2 \\
\hline Eurasia . & 3.5 & 3.3 & 2.3 & 0.5 & 4.0 & 2.3 \\
\hline China $\ldots \ldots \ldots \ldots \ldots \ldots \ldots$ & NA & 10.1 & 7.7 & 8.1 & 6.0 & 7.0 \\
\hline Former Soviet Union (FSU) . . . . . & 3.2 & 2.1 & 2.1 & -1.9 & 3.0 & 0.5 \\
\hline Eastern Europe $\ldots \ldots \ldots \ldots$ & 3.5 & 4.2 & -0.5 & -0.7 & 3.0 & 1.1 \\
\hline Rest of World (ROW) . & 5.4 & 1.8 & 3.5 & 4.3 & 4.2 & 4.2 \\
\hline OPEC $\ldots \ldots \ldots \ldots \ldots \ldots$ & 5.1 & -0.1 & 2.4 & 4.3 & 4.0 & 4.2 \\
\hline Other ROW $\ldots \ldots \ldots \ldots \ldots$ & 5.6 & 2.7 & 3.9 & 4.3 & 4.2 & 4.3 \\
\hline
\end{tabular}

OECD = Organization for Economic Cooperation and Development.

OPEC = Organization of Petroleum Exporting Countries.

NA $=$ Not available.

Note: Projected growth rates are calculated from aggregate real gross domestic product in 1985 dollars at 1985 exchange rates.

Sources: History: International Energy Agency, Energy Statistics and Balances of Non-OECD Countries 1990-1991 (1993); Wharton Econometric Forecasting Associates, World Economic Service and World Economic Service Historical Data (July 1993). Projections: Energy Information Administration, World Energy Projection System, 1994.

approach full industrial status. Similar variations exist among the countries comprising the Eurasia grouping (China, the former Soviet Union, and Eastern Europe). While their combined economic growth rate is assumed to be 2.3 percent per year, a detailed review reveals a range from China's phenomenal 7.0-percent annual rate of increase to 0.5 percent for the former Soviet Union (FSU)-even assuming a substantial recovery after 10 years of average negative growth.

Reflecting the differential economic growth rates, total primary energy consumption is projected to increase by an average of 1.4 percent per year between 1990 and 2010 in the OECD, 2.7 percent per year in the ROW, and 1.3 percent per year in Eurasia. In short, energy consumption in Eurasia and the developed countries is expected to rise about half as rapidly as in the less developed countries that form the Rest of World. Instead of consuming slightly more than half of all the energy in the world each year, as it did in 1990, the OECD by 2010 will be consuming just under 50 percent. Adding to the uncertainty of energy prospects for many
ROW countries, however, is considerable uncertainty about the geological potential of unexplored regions.

As in 1992, the largest consumers of energy in 2010 are expected to be the United States, the FSU, and China (Table A2). Taken together, the OECD countries of Europe now rank just behind the United States in total energy consumption-consuming almost three-quarters as much energy as does the United States, and they are projected to keep this relative position through 2010. Reflecting internal economic and political disruptions, the FSU is expected to show an absolute decline in energy consumption though 1995 and not return to the levels of the early 1990's until at least the year 2000. In contrast, China is projected to increase its annual energy consumption, on average, twice as fast as energy consumption grows world wide between 1990 and 2010 .

After the United States, Japan is expected to consume the most energy among the OECD countries-accounting for somewhat more than a quarter of the U.S. amount by 2010. However, Japan (whose future eco- 
nomic growth is currently expected to be the fastest in the OECD) today produces less than one-fifth of its own energy requirements; and it will have to import almost all of the energy it consumes in 2010 [11, pp. 110 and 118]. Japan plans to limit its energy shortfall through domestic energy supplies of nuclear power, making its plans for that energy source among the most ambitious in the world. Nevertheless, Japan will also have to expand its imports of all fossil fuels substantially over this period.

OECD countries within Europe will likewise need to import considerably more energy to meet growing demands, although OECD Europe will probably try to diversify its energy supplies to help reduce specific reliance on oil imports. Specifically, its imports of natural gas will be promoted by desires for a relatively clean-burning alternative to coal. Still, OECD European coal imports should grow as well-especially in countries such as the United Kingdom, where domestic mining operations that are not competitive in world markets are phasing down.

Oil has contributed more than any other form of primary energy to shaping modern economic life around the world, and it is expected to continue to be the main energy source worldwide through the year 2010 (Figure 11 and Table A1). However, Eurasia does not follow this pattern (Figure 12). More than three-quarters of the total energy consumed in China in 1990 was coal, and only 18 percent was oil. In the FSU, natural gas repre-

Figure 11. World Energy Consumption by Type, 1980-2010

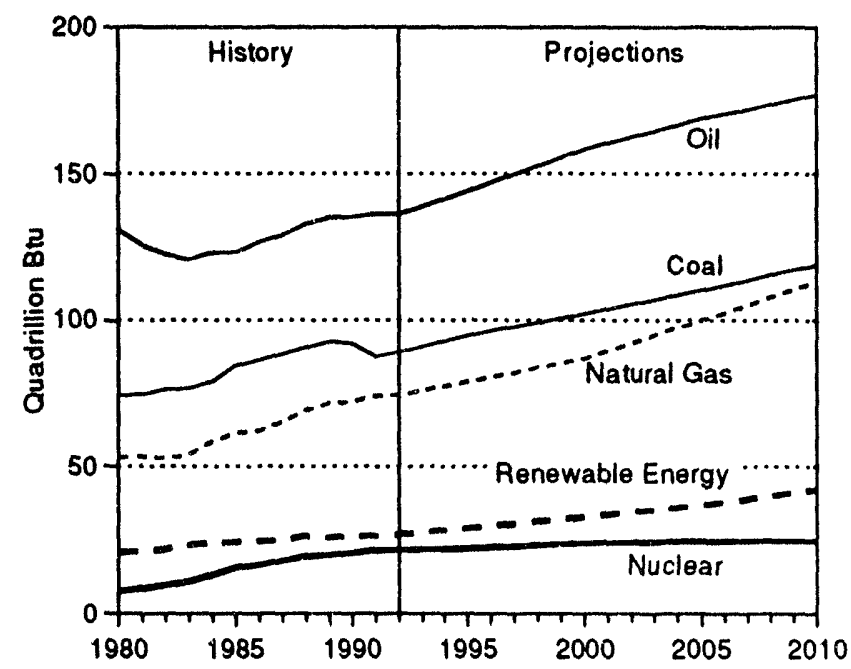

Sources: History: Energy Information Administration, International Energy Annual 1992, DOE/EIA-0219(92), Tables A10 through A14 and related data base. Projections: Table A1. sented 40 percent of the total 1990 energy consumption compared to oil's 30-percent share.

Worldwide, oil is expected to lose some relative importance over the projection period, going from 39 percent of total energy consumption in 1990 to 37 percent in 2010 (Figure 2 on page 1). Many countries seeking to diversify energy supplies or to reduce the environmental problems associated with the burning of coal could pursue policies that encourage the development and importation of natural gas. This appears to be the case in several Western European countries. There could be considerable growth in natural gas trade, particularly between such areas of growing demand as Western Europe and those areas that possess large reserves of natural gas-such as the Middle East and Russia. This trade could accelerate after the year 2000, when Western Europe will have exploited its own gas reserves more fully.

Although all regions of the world (and particularly the developing countries) will continue to feel pressure to pursue policies that encourage economic growth and raise living standards, an unfortunate fact is that the energy used to spur economic growth could also contribute greatly to the world's environmental problems. To address some of the energy-related environmental problems around the world, international policies and agreements will probably be increasingly concerned with meeting the dual objectives of promoting economic growth and protecting the environment. Policies

Figure 12. Share of Eurasia Energy Consumption by Type, $1990-2010$

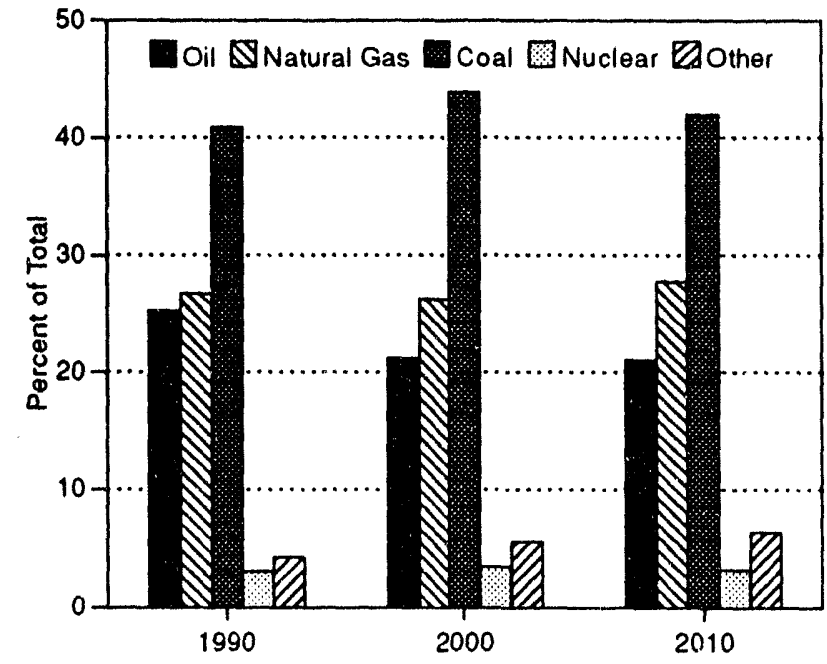

Sources: History: Energy Information Administration (EIA), In'ernational Energy Annual 1992, DOE/EIA-0219(92), Tables A9 through A14 and related data base. Projections: EIA, World Energy Projection System, 1994. 
concerning technological transfer and international financial cooperation in the exploration and development of regions with energy resource potential will play an important role in developing new sources of energy, particularly among the developing countries and within the FSU.

The extensive use of coal in China, which seems almost certain to continue in the foreseeable future, provides an example. Unless new policies or technologies change these projected trends, coal consumption in China will add considerably to world carbon emissions while also threatening an exacerbation of loral air quality. In pursuing economic growth, China and other developing countries will probably focus on certain industries that are highly energy intensive, adding further to the growth in energy use. In addition, the ongoing growth of urban areas in many ROW countries will be accompanied by greater demands for transportation, electrification, and the other energy-using services customarily associated with economic development. Increased incomes bring increased dernands for modern conveniences that increase the overall energy intensity of daily activity.

Countries like China could seek to support necessary economic growth through the further development and use of hydroelectric power. Prospects for expanding the use of this energy source are particularly good in China and in other developing countries that have unexploited water resources. As with other energy sources, however, hydroelectric power has its own environmental costs-centering on land degradation and population displacement. 


\title{
The World Oil Market
}

\author{
Assuming no political surprises, oil prices could climb back up slowly, \\ but Persian Gulf primacy and shaky outlook for FSU exports add uncertainty.
}

Within the past iwo decacles, world oil prices have clearly reflected both market forces and policy actions involving both exporters and importers (Figure 4 on page 2). The price projections shown in Table 2 do not include events such as wars, embargoes, natural catastrophes, or even major and unanticipated new oil discoveries-events that are by their nature unpredictable. Rather, they reflect more general assumptions about the influence of economic growth on oil demand; the availability of oil reserves relative to rates of oil production; the desire to develop oil reserves; and the pressures of current policies to emphasize secure supplies and avoid unnecessary pollution. The impact of a hypothetical oil supply disruption on world oil prices and other selected economic indicators is, however, considered later in this section.

\section{World Oll Prices}

Trends in world oil supplies and demands assumed here imply that world oil prices will stabilize in 1994 and 1995, then rise slowly through the year 2010. However, prices should remain well below the record highs of 1980 and 1981 throughout the projection period. In fact, prices in the Base Case are not projected to regain the 1990 level of $\$ 23$ per barrel-in constant 1992 dollars-until well after the year 2000 and, in the low price path, not until after 2010.

The world oil price paths presented in this report range between $\$ 15$ and $\$ 24$ per barrel for the year 2000 , and between $\$ 20$ and $\$ 34$ per barrel in 2010 . These ranges were determined by changing assumptions for this period about the level of oil production from the Organization of Petroleum Exporting Countries (OPEC) and the level of net exports from Eurasia to the countries of the Organization for Economic Cooperation and Development (OECD) and the Rest of World (ROW), with the same economic growth rates assumed across all cases. The derivation of the three world oil price projections is discussed further in Appendix B. The Base Case price path assumes business-as-usual
Table 2. World Oll Prices, 1979-2010 (1992 Dollars per Barrel)

\begin{tabular}{|c|c|c|c|c|}
\hline \multicolumn{2}{|c|}{ Year } & $\begin{array}{c}\text { Low Price } \\
\text { Case }\end{array}$ & $\begin{array}{l}\text { Base } \\
\text { Case }\end{array}$ & $\begin{array}{c}\text { High Price } \\
\text { Case }\end{array}$ \\
\hline 1979 & $\ldots \ldots$ & & $\$ 40.00$ & \\
\hline 1980 & $\ldots \ldots$ & & 57.15 & \\
\hline 1981 & $\ldots \ldots$ & & 56.77 & \\
\hline$\$ 982$ & $\ldots \ldots$ & & 48.40 & \\
\hline 1983 & $\ldots \ldots$ & & 40.62 & \\
\hline 1984 & $\ldots \ldots$ & & 38.37 & \\
\hline 1985 & $\ldots \ldots$ & & 34.57 & \\
\hline 1986 & $\ldots \ldots$ & & 17.47 & \\
\hline 1987 & $\ldots \ldots$ & & 21.92 & \\
\hline 1988 & $\ldots \ldots$ & & 16.94 & \\
\hline 1989 & $\ldots \ldots$ & & 20.15 & \\
\hline 1990 & $\ldots \ldots$ & & 23.24 & \\
\hline 1991 & $\ldots \ldots$ & & 19.19 & \\
\hline 1992 & $\ldots \ldots$ & & 18.20 & \\
\hline 1993 & $\ldots \ldots$ & $\$ 16.38$ & 16.69 & $\$ 16.87$ \\
\hline 1994 & $\ldots \ldots$ & 15.43 & 16.40 & 17.50 \\
\hline 1995 & $\ldots \ldots$ & 15.10 & 17.00 & 18.40 \\
\hline 1996 & $\ldots \ldots$ & 14.90 & 17.70 & 19.40 \\
\hline 1997 & $\ldots \ldots$ & 14.80 & 18.30 & 20.50 \\
\hline 1998 & $\ldots \ldots$ & 14.90 & 19.10 & 21.70 \\
\hline 1999 & $\ldots \ldots$ & 15.10 & 19.90 & 23.00 \\
\hline 2000 & $\ldots \ldots$ & 15.40 & 20.70 & 24.20 \\
\hline 2001 & $\ldots \ldots$ & 15.90 & 21.70 & 25.50 \\
\hline 2002 & $\ldots \ldots$ & 16.40 & 22.60 & 26.70 \\
\hline 2003 & $\ldots \ldots$ & 16.90 & 23.50 & 27.90 \\
\hline 2004 & $\ldots \ldots$ & 17.20 & 24.30 & 29.00 \\
\hline 2005 & $\ldots \ldots$ & 17.50 & 24.90 & 29.90 \\
\hline 2006 & $\ldots \ldots$ & 17.90 & 25.60 & 30.90 \\
\hline 2007 & $\ldots \ldots$ & 18.50 & 26.30 & 31.80 \\
\hline 2008 & $\ldots \ldots$ & 19.10 & 27.00 & 32.70 \\
\hline 2009 & $\ldots \ldots$ & 19.60 & 27.60 & 33.40 \\
\hline 2010 & $\ldots \ldots$ & 20.20 & 28.20 & 34.10 \\
\hline
\end{tabular}

Note: Prices represent the U.S. refiner acquisition cost of imported crude oil.

Sources: History: Energy Information Administration (EIA), Monthly Energy Review, DOE/EIA-0035(93/12), Table 9.1; and U.S. gross domestic product (GDP) implicit deflators from EIA, Annual Energy Review 1992, DOE/EIA0384(92). Projections: EIA, National Energy Modeling System reference scenario (run AEO94B.D1221934), low world oil price scenario (run LWOP94.D1221932), and high world oil price scenario (run HWOP94.D1221932). 
supply and demand decisions, including those by OPEC. They are reasonable outcomes, given past performance and the underlying assumptions; but history has shown that it is exceedingly difficult-if not impossible-to predict the twists and turns of commodity prices. World o:l prices are no exception.

History shows how external forces might cause even wider variations in oil price-with OPEC actions alone adding most of the uncertainty. In Figure 4 on page 2, the first price hike was caused by the Arab Oil Embargo in 1973-74. The second spike resulted from the 1978-79 Iranian Revolution and subsequent market actions. The 1986 price plunge occurred when Saudi Arabia shifted from a policy of holding its production down in the interest of price stability to one of exporting more of its low-cost oil in order to gain market share. Finally, prices jumped up briefly in 1990 when Iraq invaded Kuwait to begin the Persian Gulf War. The 1990 Persian Gulf crisis caused oil prices to go from just over $\$ 15$ per barrel in June to just under $\$ 33$ per barrel by October [12, p. 17].

Subsequent to the Arab Oil Embargo, the oil-importing countries undertook policy and market actions to protect their domestic economies from the major price shocks and to try to add stability to the world oil market itself. The industrialized OECD countries in particular developed policies and programs-both individually and jointly - to ensure safe and adequate energy supplies that might permit uninterrupted economic growth. One enduring result of these actions was the creation of strategic petroleum reserves in the United States, Japan, and Germany. Their existence is intended to discourage sudden and arbitrary price hikes.

By the end of 1993, world oil prices had returned to pre-Persian Gulf War levels-the result of weak global demand relative to supply, plus a combination of political actions that had been taken or were pending. Actions included a decision in November by OPEC to forego any effort at production cutbacks, despite a soft oil market and a sluggish world economy, and the increased possibility that the United Nations might soon lift the embargo imposed on Iraqi oil exports when Iraq formally agreed in November to long-term United Nations monitoring of its weapons systems. The potential for Iraqi exports added to the concern for a worldwide oil surplus, since production from the North Sea had increased and a surplus of oil stocks had built up during the first three quarters of 1993 [45, pp. 1-2]. At the same time, additional gains in production outside OPEC were coming from Canada, Syria,
Yemen, Angola, China, Malaysia, and Papua New Guinea. Output from this group rose 2.2 percent during the first half of 1993 [55, p. 53].

Supply and demand forces are expected to result in moderate growth in oil prices through 2010. Oil demand typically increases as economies grow (that is, people and nations will tend to use more petroleumand be willing to pay more for it-as they prosper). On the other hand, rising prices stimulate production. Demand for oil should remain particularly strong among the developing countries, where the focus has been on econcmic growth as opposed to energy conservation or efficiency, and where fewer energy alternatives to oil will be available and affordable during the projection period. Oil has been particularly important in countries with limited domestic energy resources, because of its relatively low cost and ease of transport in comparison with other energy sources [55, p. 48].

On the supply side, future production decisions by OPEC will continue to be a dominant factor in determining prices and trends on the world oil market. OPEC produces more than one-third of all oil consumed in the world today, but it could easily raise that share to 46 percent or more by 2010 (Figure 13).

Figure 13. OPEC and Perslan Gulf Oil Production as a Percentage of World Oll Consumption, 1973-2010

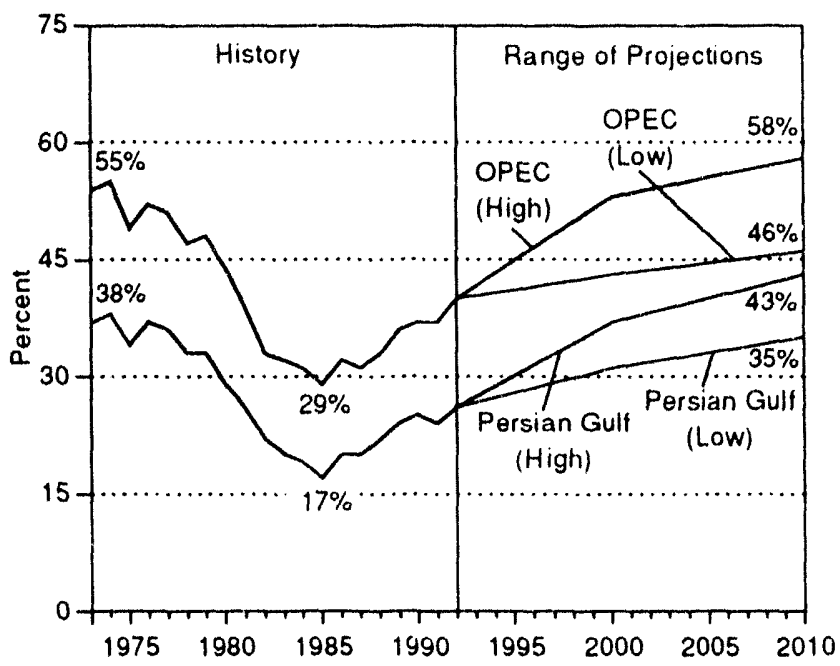

Sources: History: Energy Information Administration, International Petroleum Statistics Report, DOE/EIA.0520(94/01), Table 4.4; International Energy Annual 1992, DOE/ElA-0219(92), Table 8; and Annual Energy Review 1992, DOE/EIA-0384(92), Table 11.10. Projections: Assumed utilization rates applied to production capacities in Table 6, divided by world consumption from Table 3. 
Bolstered by huge reserves, OPEC production is projected to keep growing throughout the projection period; but far less surplus production capacity exists at the moment outside OPEC, and production in the ROW countries is expected to peak around 2000 (Table 3). As a result, the world is likely to become even more dependent on oil from OPEC, particularly from the Persian Gulf. About two-thirds of the world's known petroleum reserves are located in the Middle East (Table 4 and Figures 14 and 15).

Table 3. World Oll Consumption and Production, Base Case (Million Barrels per Day)

\begin{tabular}{|c|c|c|c|c|c|c|}
\hline \multirow[b]{2}{*}{ Supply and Disposition } & \multicolumn{3}{|c|}{ History } & \multicolumn{3}{|c|}{ Projections } \\
\hline & 1990 & 1991 & 1992 & 2000 & 2005 & 2010 \\
\hline \multicolumn{7}{|l|}{ Production } \\
\hline United States ${ }^{a} \ldots \ldots \ldots \ldots \ldots$ & 9.68 & 9.88 & 9.77 & 8.0 & 7.8 & 8.1 \\
\hline Canada $\ldots . . . \ldots \ldots \ldots$ & 2.02 & 2.03 & 2.12 & 2.2 & 2.5 & 2.5 \\
\hline OECD Europe $\ldots \ldots \ldots \ldots \ldots$ & 4.58 & 4.81 & 5.08 & 6.4 & 5.3 & 4.8 \\
\hline OPEC $\ldots \ldots \ldots \ldots \ldots \ldots$ & 24.81 & 24.93 & 26.38 & 35.5 & 40.9 & 44.0 \\
\hline Other Rest of World ${ }^{b} \ldots \ldots \ldots$ & 11.12 & 11.43 & 11.72 & 13.0 & 12.3 & 12.1 \\
\hline Total $\ldots \ldots \ldots \ldots \ldots \ldots \ldots$ & 52.21 & 53.08 & 55.07 & 65.1 & 68.8 & 71.4 \\
\hline Net Eurasia Exports $\ldots \ldots \ldots \ldots$ & 2.17 & 1.36 & 1.58 & 1.2 & 1.4 & 1.6 \\
\hline \multicolumn{7}{|l|}{ Consumption } \\
\hline United States $^{a} \ldots \ldots \ldots \ldots \ldots$ & 16.99 & 16.71 & 17.03 & 19.3 & 20.4 & 21.3 \\
\hline U.S. Territories $\ldots \ldots \ldots \ldots \ldots$ & 0.21 & 0.24 & 0.21 & 0.3 & 0.3 & 0.3 \\
\hline Canada $\ldots \ldots \ldots \ldots \ldots \ldots$ & 1.69 & 1.62 & 1.64 & 1.9 & 1.9 & 1.9 \\
\hline Japan $\ldots \ldots \ldots \ldots \ldots$ & 5.14 & 5.28 & 5.45 & 6.8 & 7.1 & 7.2 \\
\hline Australia and Now Zealand ..... & 0.82 & 0.81 & 0.82 & 1.0 & 1.0 & 1.1 \\
\hline OECD Europe $\ldots \ldots \ldots \ldots \ldots$ & 12.90 & 13.38 & 13.61 & 15.5 & 15.9 & 16.0 \\
\hline Rest of World . . . . . . . . . & 16.07 & 16.49 & 17.56 & 22.0 & 23.9 & 25.6 \\
\hline Total $\ldots \ldots \ldots \ldots \ldots \ldots$ & 53.82 & 54.53 & 56.33 & 66.7 & 70.5 & 73.3 \\
\hline Stock Draw and Discrepancy ... & -0.57 & 0.08 & -0.32 & 0.3 & 0.3 & 0.3 \\
\hline \multirow{2}{*}{\multicolumn{7}{|c|}{$\begin{array}{l}\text { Eurasia } \\
\text { Production }\end{array}$}} \\
\hline China $\ldots \ldots \ldots \ldots \ldots \ldots$ & 2.77 & 2.83 & 2.84 & 3.1 & & \\
\hline Former Soviet Union . . . . . . . . & 11.40 & 10.41 & 8.91 & 8.5 & 9.7 & 11.0 \\
\hline Eastern Europe $\ldots \ldots \ldots \ldots \ldots$ & 0.34 & 0.29 & 0.25 & 0.4 & 0.4 & 0.4 \\
\hline Total $\ldots \ldots \ldots \ldots \ldots \ldots$ & 14.51 & 13.54 & 12.00 & 11.9 & 13.3 & 14.8 \\
\hline \multicolumn{7}{|l|}{ Consumption } \\
\hline China $\ldots \ldots \ldots \ldots \ldots \ldots$ & 2.30 & 2.50 & 2.63 & 3.2 & 3.6 & 4.0 \\
\hline Former Soviet Union . . . . . . . . & 8.39 & 8.35 & 6.70 & 6.2 & 6.8 & 7.5 \\
\hline Eastern Europe $\ldots \ldots \ldots \ldots \ldots$ & 1.65 & 1.33 & 1.09 & 1.3 & 1.5 & 1.7 \\
\hline Total $\ldots \ldots \ldots \ldots \ldots \ldots$ & 12.34 & 12.18 & 10.42 & 10.7 & 11.9 & 13.2 \\
\hline World Oil Consumption ......... & 66.16 & 66.71 & 66.74 & 77.4 & 82.4 & 86.5 \\
\hline
\end{tabular}

Includes the $\mathbf{5 0}$ States and the District of Columbia.

Includes Australia, New Zealand, and the U.S. Territories.

OECD = Organization for Economic Cooperation and Development.

OPEC $=$ Organization of Petroloum Exporting Countries.

Notes: Production includes crude oil, natural gas liquids, refinery gains, hydrogen, and other hydrocarbons. Totals may not equal sum of components because of independent rounding.

Sources: History: Energy information Administration (EIA), International Energy Annual 1992, DOE/EIA-0219(92), Tables 8 and D2. Projections: EIA, Annual Energy Outlook 1994, DOE/ElA-0383(94), Table A19, and World Energy Projection System, 1994. 
World oil prices are projected to rise as dependence on OPEC oil rises. The rate at which world oil prices escalate will depend largely on how OPEC decides to expand its own production capacity-especially among the Persian Gulf countries, which are the only ones that can add enough capacity to meet the full anticipated increase in demand (Table 3). Because of the central role of OPEC production expansion decisions to the determination of world oil prices, assumptions about OPEC production rates are one of the key market factors varied to produce the low and high world oil price paths (Table 2). For the low price path, OPEC production is assumed to reach 49 million barrels per day in 2010, corresponding to a price of about $\$ 20$ per

\section{Table 4. World Crude Oil Reserves}

(Billion Barrels)

\begin{tabular}{|c|c|c|}
\hline \multirow[b]{2}{*}{ Region/Selected Countries } & \multicolumn{2}{|c|}{ Estimated Crude Oll Reserves } \\
\hline & $\begin{array}{l}\text { Oil and Gas Journal } \\
(1 / 1 / 94)\end{array}$ & $\begin{array}{c}\text { World Oil } \\
(1 / 1 / 93)\end{array}$ \\
\hline North Amorica ........................... & 79.8 & 80.1 \\
\hline 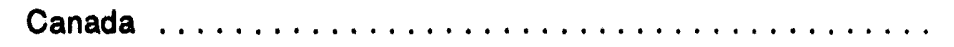 & 5.1 & 5.7 \\
\hline Mexico . . . . . . . . . . . . . . . . . . . . . & 50.9 & 51.2 \\
\hline United States $\ldots \ldots \ldots \ldots \ldots \ldots \ldots \ldots \ldots \ldots \ldots$ & 23.7 & 22.8 \\
\hline Central and South America $\ldots \ldots \ldots \ldots \ldots \ldots$ & 74.1 & 73.9 \\
\hline 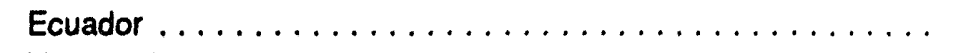 & 2.0 & 2.0 \\
\hline Venezuela $\ldots \ldots \ldots \ldots \ldots \ldots \ldots \ldots \ldots \ldots \ldots$ & 63.3 & 63.3 \\
\hline Western Europe $\ldots \ldots \ldots \ldots \ldots \ldots \ldots \ldots \ldots \ldots \ldots$ & 16.6 & 23.7 \\
\hline United Kingdom $\ldots \ldots \ldots \ldots \ldots \ldots \ldots \ldots \ldots \ldots$ & 4.6 & 4.6 \\
\hline 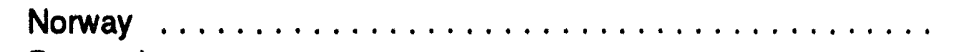 & 9.3 & 16.8 \\
\hline Donmark $\ldots \ldots \ldots \ldots \ldots \ldots \ldots \ldots \ldots \ldots$ & 0.8 & 0.7 \\
\hline Eastern Europe and Former Soviet Union . . . . . . . . . . & 59.2 & 188.8 \\
\hline Former Soviet Union $\ldots \ldots \ldots \ldots \ldots \ldots \ldots \ldots \ldots$ & 57.0 & 186.9 \\
\hline Middle East $\ldots \ldots \ldots \ldots \ldots \ldots \ldots \ldots \ldots \ldots \ldots$ & 662.9 & 596.6 \\
\hline 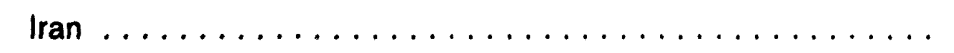 & 92.9 & 61.3 \\
\hline 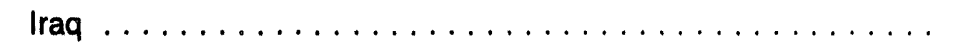 & 100.0 & 99.8 \\
\hline 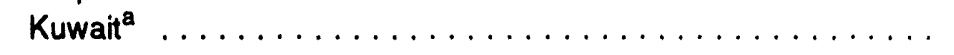 & 96.5 & 94.8 \\
\hline 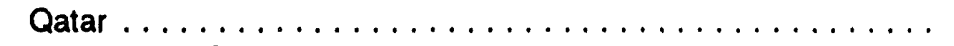 & 3.7 & 4.3 \\
\hline Saudi Arabia ${ }^{a} \ldots \ldots \ldots \ldots \ldots \ldots \ldots \ldots \ldots$ & 261.2 & 261.0 \\
\hline United Arab Emirates $\ldots \ldots \ldots \ldots \ldots \ldots \ldots \ldots$ & 98.1 & 64.7 \\
\hline Africa $\ldots \ldots \ldots \ldots \ldots \ldots \ldots \ldots \ldots \ldots \ldots \ldots \ldots$ & 62.0 & $\mathbf{7 4 . 7}$ \\
\hline 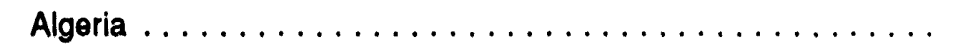 & 9.2 & 10.4 \\
\hline Egypt $\ldots \ldots \ldots \ldots \ldots \ldots \ldots \ldots \ldots \ldots \ldots \ldots$ & 6.3 & 3.6 \\
\hline 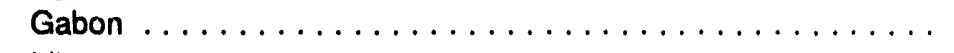 & 0.7 & 0.8 \\
\hline 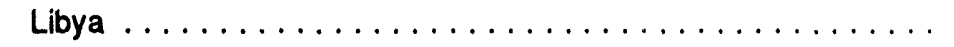 & 22.8 & 38.2 \\
\hline Nigeria $\ldots \ldots \ldots \ldots \ldots \ldots \ldots \ldots \ldots \ldots \ldots$ & 17.9 & 18.2 \\
\hline Tunisia $\ldots \ldots \ldots \ldots \ldots \ldots \ldots \ldots \ldots \ldots \ldots \ldots$ & 1.7 & 0.5 \\
\hline Far East/Oceania $\ldots \ldots \ldots \ldots \ldots \ldots \ldots \ldots \ldots$ & 44.6 & 54.0 \\
\hline Australia/Now Zealand $\ldots \ldots \ldots \ldots \ldots \ldots \ldots \ldots$ & 1.8 & 3.3 \\
\hline 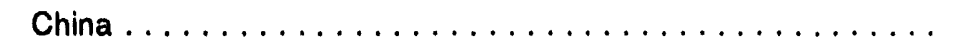 & 24.0 & 29.6 \\
\hline 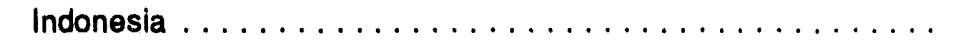 & 5.8 & 8.4 \\
\hline Total OPEC $\ldots \ldots \ldots \ldots \ldots \ldots \ldots \ldots \ldots \ldots \ldots$ & 772.1 & 725.3 \\
\hline World Total $\ldots \ldots \ldots \ldots \ldots \ldots \ldots \ldots \ldots \ldots \ldots \ldots$ & 999.1 & $1,091.9$ \\
\hline
\end{tabular}

ancludes 50 percent of the Neutral Zone.

OPEC = Organization of Petroleum Exporting Countries.

Note: Totals may not equal sum of components due to independent rounding.

Sources: Oil and Gas Journal, Vol. 91, No. 52 (December 27, 1993), pp. 44-45; World Oil, Vol. 214, No. 8 (August 1993), p. 30. 
barrel, while in the high price path, OPEC production is assumed to reach $\mathbf{4 0}$ million barrels per day in 2010, giving a price of $\$ 34$ per barrel $[8, \mathrm{pp} .142,164]$.

Assumptions about the net export posture of Eurasia with respect to the rest of the world are also important in assessing future world oil prices. High net exports by Eurasia would restrain world oil prices, and low net exports would contribute to higher prices. High net exports would result if low economic growth leads to lower demands in Eurasia throughout the projection period while Western capital and technology are employed to reverse the declining oil production trends. Low net exports would result from healthier

\section{Figure 14. Wurld Oll Reserves}

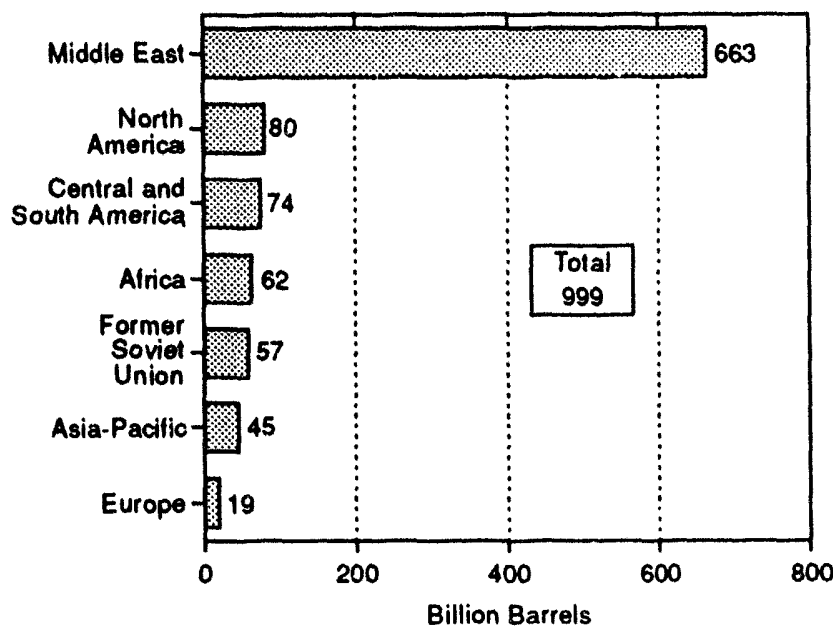

Source: Oil and Gas Journal (December 27, 1993), pp. 44-45.

\section{Figure 15. OPEC Oll Reserves}

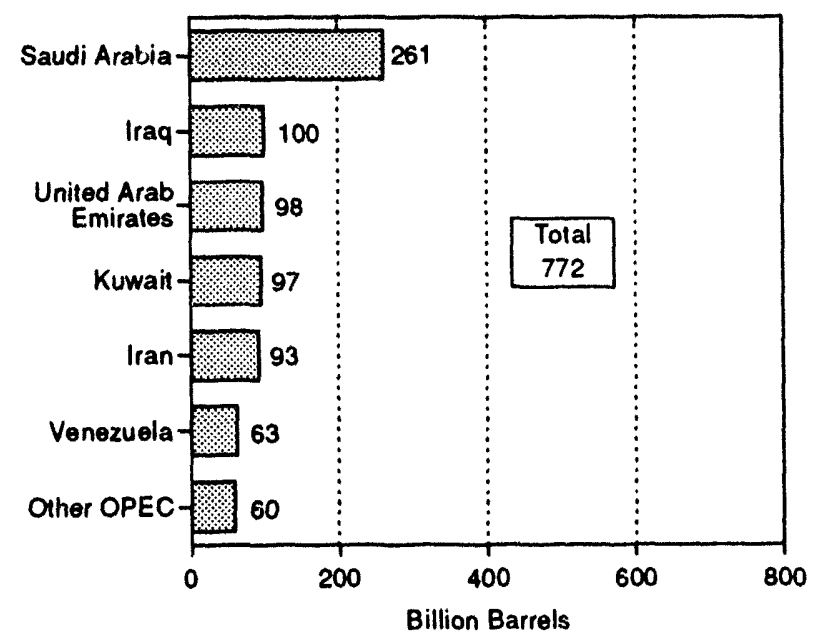

Source: Oil and Gas Journal (December 27, 1993), pp. 44-45.
Eurasian economic growth-which would increase domestic use and make less oil available for export. Net Eurasian exports vary between zero (contributing to global conditions of low supply and high price) and 3.2 million barrels per day (with resultant high supply and lower price) by the end of the projection period under the three world oil price paths. However, there is enormous oil market uncertainty-even in the nearterm-with respect to these regions.

\section{World Oil Consumption}

For most countries around the world, oil is a key ingredient for economic growth. World oil consumption is projected to grow by 1.3 percent per year between 1990 and 2010 (Figure 16 and Table A3 in Appendix A). Oil consumption is expected to grow most rapidly in the Rest of World countries (Figure 17), but the industrialized countries of the OECD are expected to continue to be the largest consumers of oil. Having accounted for about 57 percent of world oil consumption in 1990, OECD is projected to consume 55 percent of the world total in 2010 (Figure 18).

Oil is currently the most important energy source in the majority of OECD countries. It should continue to contribute more than half of all energy consumed in Italy and Japan through 2010. Oil's share of U.S. energy consumption is expected to remain essentially stable for the entire two decades of the projection period. Oil should also supply about half of all energy consumed in the ROW countries taken together, with oil's share in those developing nations rising between 1990 and 2000 but then declining relative to natural gas and renewable

Figure 16. World Oil Consumption, 1980-2010

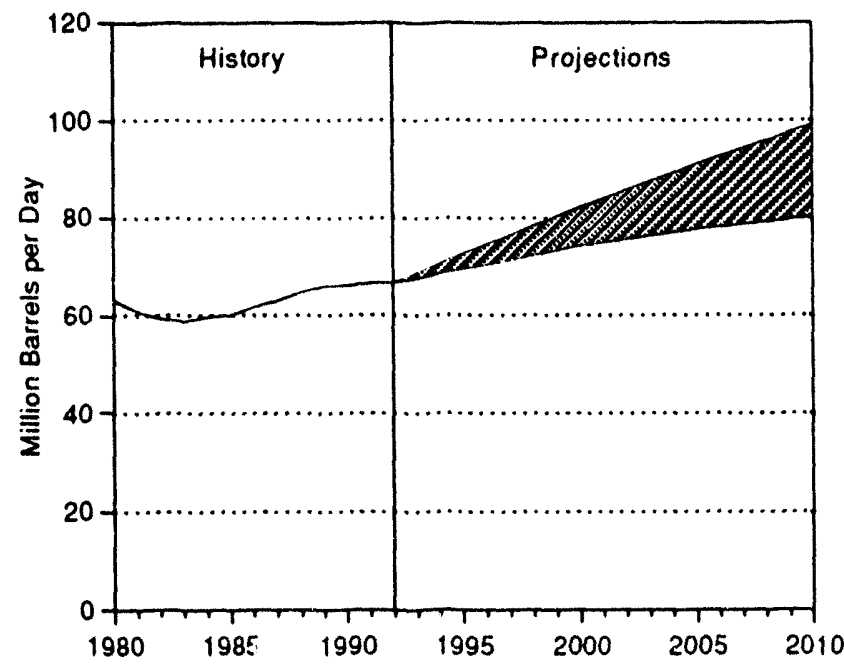

Sources: History: Energy Information Administration, International Energy Annual 1992, DOE/EIA-0219(92). Table 8 and related data base. Projections: Table A3. 
energy sources in the decade that follows. This subsequent decrease for ROW helps to explain why oil is projected to play a slightly smaller relative role worldwide after 2000 (Figure 19).

Oil consumption is expected to increase most rapidly in the countries with the fastest growing economies-the developing ROW country group shown in Table 1 on page 7. The gross domestic product (GDP) growth rate

\section{Figure 17. World Oll Consumption by Major Country Groupings, 1980-2010}

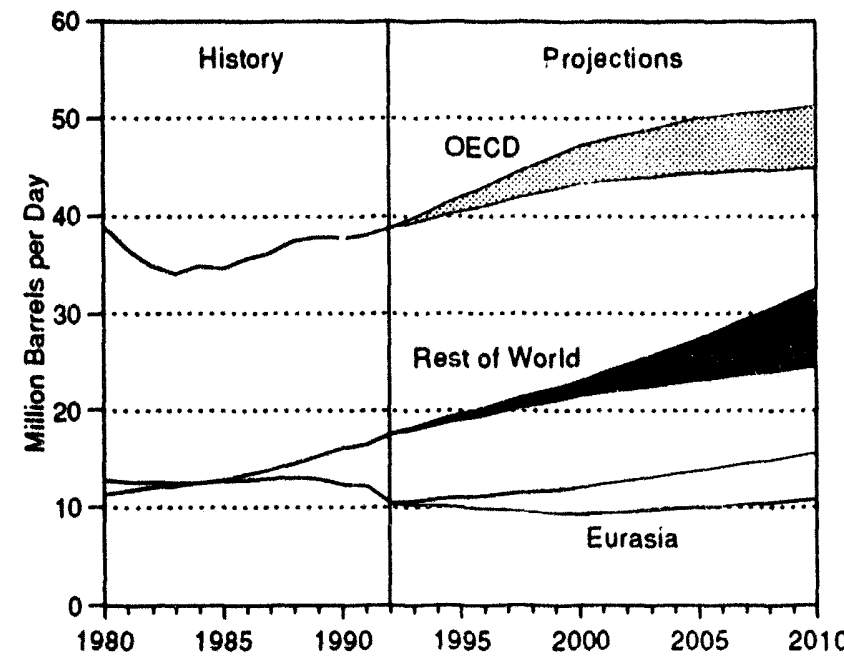

Sources: Hiatory: Energy Information Administration, International Energy Annual 1992, DOE/ElA-0219(92), Table 8 and related data base. Projections: Table A3.

Figure 18. Share of Oll Consumption by Major Country Groupings, 1980-2010

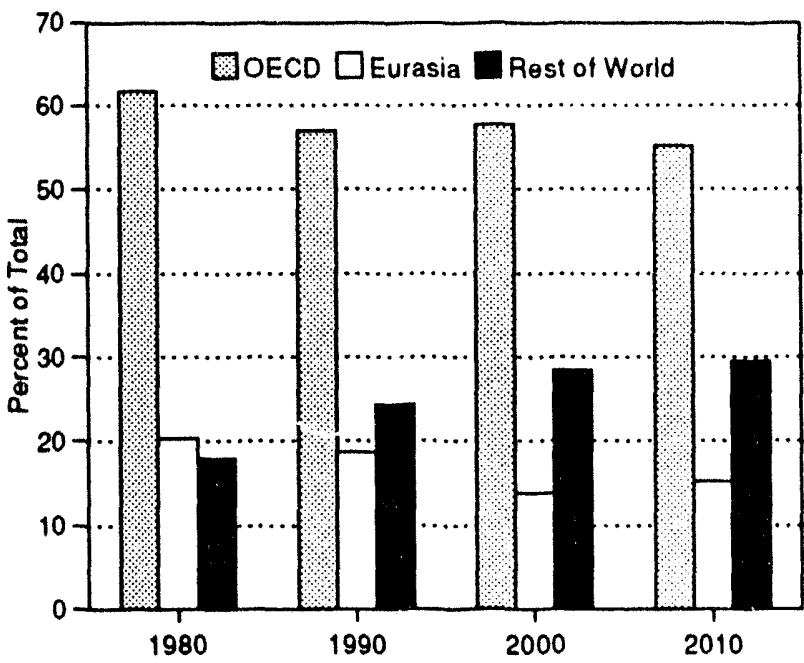

Sources: History: Energy Information Administration, International Energy Annual 1992, DOE/EIA-0219(92), Table 8 and related data base. Projections: Table A3. for the ROW is assumed to average 4.2 percent between 1990 and 2010 contributing to a projected growth in ROW oil consumption averaging 2.3 percent per year over this period. Oil consumption will grow most rapidly in the developing nations of Asia and the Middle East. China exemplifies rapid growth in economic activity, causing rapid growth in energy consumption - so that China will have to become a net importer of oil in the near future. A growing motor transportation sector will fuel much of this demand growth. In sharp contrast to China, the FSU should reduce oil consumption over the next several years. Changes in FSU policies will also affect Eastern Europe which will now have to pay world prices for the FSU oil it imports.

The convenience and efficiency of oil makes it the dominant fuel for many uses, especially in motor transportation, where alternative fuels are at a clear disadvantage. However, the large concentration of vehicles in urban s.reas has been a major factor in traffic congestions and air pollution due to ozone from $\mathrm{CO}$ and $\mathrm{NO}_{2}$ emissions. Because of oil's primacy as an energy source, its combustion worldwide currently produces more carbon emissions, a major component of greenhouse gases, than does that of any other fossil fuel-44 percent of the world total in 1992. Most countries in the OECD have imposed heavy taxes on oil consumption (mainly on gasoline), both to discourage consumption and to raise revenues (Table 5).

Figure 19. Oll Consumption as a Percentage of Total Energy Consumption, 1980-2010

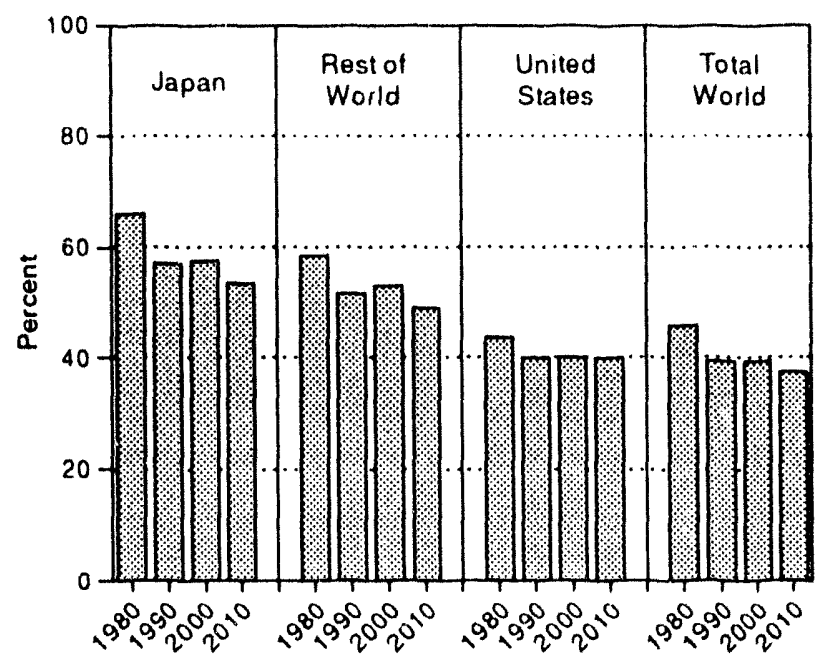

Sources: History: Energy Information Administration (EIA), International Energy Annual 1992, DOE/EIA-0219(92), Tables A9 and A10 and related data base. Projections: EIA, World Energy Projection System, 1994. 


\section{Non-OPEC OII Production Potential}

Oil production in the non-OPEC countries outside Eurasia (which includes the former Soviet Union, Eastern Europe, and China) is expected to increase only slightly for the remainder of this decade and decline thereafter [41]. Production for Eurasia, which involves more uncertainty, is projected to decline through 2000 before turning upward (Table 3).

Increases in North Sea production, coupled with exploration successes and favorable tax provisions in many developing countries, has more than offset the continued decline in U.S. production in recent years. But the weakness in world oil prices that is expected to continue into the mid-1990's resulked in slightly lower non-OPEC production levels in the International Energy Outlook 1994 (IEO94) as compared with those presented in the IEO93. This phenomenon shows itself partic- ularly in projections for the years near the end of the current decade, when IEO94 levels are slightly lower by about 200 thousand barrels per day than the comparable IEO93 Base Case estimates. With real prices expected to increase steadily after the year 2000 , non-OPEC production is expected to rebound. As a result, differences between the IEO93 and IEO94 estimates near the end of the projection period are slight, with each envisioning about 28 million barrels per day by 2010 .

Although the output from some producing fields in the North Sea has begun to decline, incremental production will be continuously added over a 3- to 5-year period from newly developed fields and shut-in fields (i.e., undeveloped fields with proven reserves). By 1998, total North Sea production is expected to surpass the 6million-barrel-per-day level and not begin any substantive decline until after the year 2000. Due to greater production of natural gas in the North Sea, significant

Table 5. Gasoline Prices and Tax Component in the OECD, 1992

\begin{tabular}{|c|c|c|c|}
\hline \multirow[b]{2}{*}{ Country } & \multicolumn{2}{|c|}{ Gasoline Prices } & \multirow{2}{*}{$\begin{array}{l}\text { Tax Component } \\
\text { (Percent of Totai) }\end{array}$} \\
\hline & Dollars per Liter & Dollars per Gallon & \\
\hline Australia $\ldots \ldots \ldots \ldots \ldots \ldots \ldots \ldots$ & $\$ 0.499$ & $\$ 1.89$ & 46.2 \\
\hline Austria $\ldots \ldots \ldots \ldots \ldots \ldots \ldots$ & 0.970 & 3.67 & 64.8 \\
\hline Bolgium $\ldots \ldots \ldots \ldots \ldots \ldots \ldots$ & 0.987 & 3.74 & 70.0 \\
\hline Canada $\ldots \ldots \ldots \ldots \ldots \ldots \ldots$ & 0.455 & 1.72 & 46.2 \\
\hline Denmark $\ldots \ldots \ldots \ldots \ldots \ldots$ & 0.961 & 3.64 & 67.2 \\
\hline Finland $\ldots \ldots \ldots \ldots \ldots \ldots \ldots$ & 1.013 & 3.83 & 68.0 \\
\hline France $\ldots \ldots \ldots \ldots \ldots \ldots \ldots$ & 0.992 & 3.75 & 77.2 \\
\hline Germany $\ldots \ldots \ldots \ldots \ldots \ldots$ & 0.981 & 3.71 & 72.4 \\
\hline Greөce ................. & 0.820 & 3.10 & 69.1 \\
\hline ireland $\ldots \ldots \ldots \ldots \ldots \ldots \ldots$ & 1.001 & 3.79 & 66.6 \\
\hline Italy $\ldots \ldots \ldots \ldots \ldots \ldots \ldots$ & 1.236 & 4.68 & 75.8 \\
\hline Japan ...................... & 0.977 & 3.70 & 46.1 \\
\hline Luxembourg $\ldots \ldots \ldots \ldots \ldots \ldots$ & 0.746 & 2.82 & 62.0 \\
\hline Netherlands $\ldots \ldots \ldots \ldots \ldots \ldots \ldots$ & 1.141 & 4.32 & 72.4 \\
\hline New Zealand $\ldots \ldots \ldots \ldots \ldots \ldots \ldots$ & 0.541 & 2.05 & 46.6 \\
\hline Norway $\ldots \ldots \ldots \ldots \ldots \ldots \ldots \ldots$ & 1.284 & 4.86 & 71.4 \\
\hline Portugal $\ldots \ldots \ldots \ldots \ldots \ldots \ldots$ & 1.083 & 4.10 & 75.4 \\
\hline Spain $\ldots \ldots \ldots \ldots \ldots \ldots \ldots \ldots$ & 0.943 & 3.57 & 69.8 \\
\hline Sweden $\ldots \ldots \ldots \ldots \ldots \ldots \ldots \ldots \ldots$ & 1.137 & 4.30 & 69.2 \\
\hline Switzerland $\ldots \ldots \ldots \ldots \ldots \ldots$ & 0.759 & 2.87 & 62.5 \\
\hline Turkey ..................... & 0.745 & 2.82 & 63.7 \\
\hline United Kingdom $\ldots \ldots \ldots \ldots \ldots \ldots$ & 0.882 & 3.34 & 69.5 \\
\hline United States $\ldots \ldots \ldots \ldots \ldots \ldots \ldots$ & 0.298 & 1.13 & 33.9 \\
\hline
\end{tabular}

OECD = Organization for Economic Cooperation and Development.

Note: One gallon equals 3.785 liters.

Source: International Energy Agency, Energy Prices and Taxes: Third Quarter 1993 (Paris, France), pp. 284 and 293. 
amounts of the increased liquid production capacity from Norway and the United Kingdom will be in the form of natural gas liquids and condensate.

Persian Gulf members of OPEC are not the only Middle East producers expected to increase production over the projection period. Use of sophisticated drilling techniques continues to expand the resource base of Oman, one of the non-OPEC countries on the Arabian Sea. By the end of the 1990's, Oman is experted to expand its present output by almost 200 thousand barrels per day. In addition, Yemen's oil production outlook seems to be quite optimistic. Expansion of its output by at least 300 thousand barrels per day seems to be realistic by the late $1990 \mathrm{~s}$-although some oil-industry analysts feel that Yemen's support of Iraq during the Gulf crisis has derailed what might have been an even broader improvement in production capacity. Througin advanced extraction technologies, Syria (still another non-OPEC country in the Middle East) is expected to increase production slightly in the near-term; but since output from some of the larger fields is declining, it is not expected to be able to maintain the increase beyond the late 1990's.

Far Eastern producers are experted to increase production by at least 500 thousand barrels per day by the end of the decade because of newly developed fields coming online and optimism regarding exploration activities. The most substantive increases should be from India, Papua New Guinea, the Philippines, and Vietnam. Later in the projection period, Bangladesh and Mongolia are expected to be new producers. There is a great deal of optimism regarding the longer-term oil production potential in Vietnam. While the output of most Far Eastern producers is expected to decline after the year 2000 because of decreased production activity from mature fields, Vietnam is expected to keep on building up its production capacity well into the following decade. Finally, although Australia's current oil output of between 500 to 600 thousand barrels per day is expected to stay practically flat through the year 2000 , that country has enough of a resource base so that it could expand its production over a 4- to 5-year period by more than 400 thousand barrels per day if the price climate should prove attractive.

In Latin America, Colombia and Peru are both expected to double their current production levels by the end of the decade because of steadily increasing production from developing fields, as well as new production. By the year 2000, Colombia should join the relatively short list of producers whose output exceeds 1 million barrels per day, while Peru's output should expand to almost 200 thousand barrels per day. In the same time frame, the once-optimistic outlook for Brazilian oil production has deteriorated somewhat, given the emergence of a less reform-minded government and the resulting pessimism regarding foreign investments in the oil sector; and now only modest production increases there are anticipated. Ecuador, which withdrew from OPEC recently, is expected to increase its output from 285 thousand barrels per day in 1990 to about 400 thousand barrels per day by the end of the decade due to expansion of its production capacity. The availability of capital remains Mexico's greatest challenge in exploiting its substantial resource base. Unless the Mexican government encourages foreign investment in their oil projects, production is not expected to increase substantially beyond its current 3.1 million barrels per day throughout the projection period.

Non-OPEC producers in Africa promise only modest increases by the end of the decade-with only the Congo and Tunisia stepping up their current levels of output as a result of expected development of recent discoveries. Because of the absence of any major new oil finds combined with normal field decline, decreases in output are expected in Cameroon, Egypt, and Zaire; but these decreases should not completely offset the increases from other countries on that continent. Beyond the year 2000, some increases might also be expected from such new African producers as Chad, the Ivory Coast, Equatorial Cuinea, Somalia, South Africa, and the Sudan.

North American production is expected to continue to fall. Canada, however, should gradually increase its production over the projection period-primarily because of the production of synthetic crude oil from its tar sands, which becomes increasingly economic over the projection period, and additional volumes of natural gas liquids. However, Canada's modest increases are not likely to be enough to offset the continued decline expected in the United States. Offshore U.S. discoveries in the Gulf of Mexico and incremental Alaskan production from the Cook Inlet field are expected to slow the decline, but not stop it.

The range of total non-OPEC production estimates presented in this outlook were based only on differences in the world oil price projections. By the end of the projection period, the range of non-OPEC supply varies between 25.4 million barrels per day with low prices and 28.9 million barrels per day with high prices. This range for non-OPEC production could be even greater if the estimates were to factor in variations in such parameters as the number of exploration wells, finding rates, reserve-to-production ratios, and advances in extraction technology. 


\section{OPEC Oll Production Capacity}

The Persian Gulf crisis gave impetus to plans by most OPEC countries to expand oil production capacity; and the programs they have already announced are expected to add about 10 million barrels per day in capacity by the end of the decade. This represents the first significant development of the vast reserves discovered during the $1980^{\prime}$ s by OPEC members, who generally offer three arguments to justify these expansions now:

- OPEC's substantial recent additions to their own reserves (arising from improved technology as well as new discoveries) have not been matched by increases in OPEC production, although non-OPEC output climbed steadily during the 1980 's on the basis of relatively insignificant reserve additions (Table 6). Because of this, the difference between OPEC and non-OPEC regions in reserves-to-production ratios has grown substantially. The bottom line is that some non-OPEC supplies are in decline; they have already peaked for some major nonOPEC producers, such as the United States and the FSU. Thus, OPEC members suggest that it will be only natural for others to turn more toward OPEC suppliers in the future.

- Most energy analysts agree that the demand for energy, particularly oil, will grow in the medium to long term-especially in the newly industrialized and developing countries. Therefore, with nonOPEC producers being the high-cost producers, incremental supply will likely come from OPEC producers.

- During past disruptions in petroleum supply, the existence of spare capacity in OPEC nations not involved in the disruption has tended to stabilize oil prices, in effect protecting the world economy. For that reason, OPEC representatives contend that their anticipatory expansion ought to be welcomed by other nations.

In point of fact, it was revealed after the Gulf crisis that OPEC had been utilizing about 80 percent of its capacity to produce oil in 1989, but that by the end of 1991 the utilization factor had increased to more than 91 percent. With Kuwait's production capacity damaged and Iraq's production capacity unavailable to the world market, the spare capacity within OPEC had dropped from more than 5 million barrels per day in the year before the crisis to only a little more than 2 million barrels per day. With such a relatively slim margin of spare capacity, OPEC is confident that it can attract the investment it needs from multinational oil companies and other firms to expand-despite the enormous demand for capital elsewhere in the world, particularly in the FSU.

The ability of individual OPEC members to raise their respective production capacities depends on the size of the oil reserves involved, the cost of developing them, and the availability of capital and technology. The huge oil reserves in the Persian Gulf region can be developed at relatively low costs; but other OPEC producers with more modest reserves (such as Algeria, Libya, and Nigeria) are likely to opt for expansion through investments in enhanced oil recovery methods rather than in developing new fields. These two fundamentally divergent approaches within OPEC could split that organization in the future, because their interests would be served by different market developments:

- Countries with very large reserves are likely to favor a future with sufficient production to keep prices stable or rising slowly. This would give consumers little incentive to switch to other fuels, and competition from non-OPEC producers would be minimized because the financial incentive to invest in new productive capacity outside OPEC. would be reduced.

- On the other hand, countries that belong to OPEC but have smaller reserves themselves will likely prefer a future in which relatively lower production sends prices higher, thus generating the maximum possible revenue from a dwindling resource base and providing funds for faster development of enhanced recovery methods.

The price projections in the IEO94 assume that the OPEC countries with large reserves will have the greatest influence on future oil market conditionskeeping price rises moderate, but achieving sufficient revenue to expand production capacity as necessary to meet growing demand.

The price of oil on world markets is the central driver in determining patterns of investment in capacity expansion. It is critical not only to the producing nations themselves, but also to the international oil companies that operate in OPEC nations. Low prices tend to discourage investment by these companies, so that capacity expansion projects are less likely to be fully achieved in a low price environment. With the return of Iraqi capacity to the export market (expected by the end of 1995), real oil prices now look as if they will remain low for the remainder of the decade. However, the price/investment relationship makes it somewhat unlikely that the OPEC capacity expansion required to maintain such a low price over the longer term will occur. 
Table 6. World OII Production Capacity Assumptions (Million Barrels per Day)

\begin{tabular}{|c|c|c|c|c|c|c|c|c|c|c|c|}
\hline \multirow[b]{3}{*}{ Region/Country } & \multirow{2}{*}{\multicolumn{2}{|c|}{ Estimates }} & \multicolumn{9}{|c|}{ Assumptions } \\
\hline & & & \multicolumn{3}{|c|}{2000} & \multicolumn{3}{|c|}{2005} & \multicolumn{3}{|c|}{2010} \\
\hline & 1990 & 1992 & $\begin{array}{l}\text { Base } \\
\text { Case }\end{array}$ & \multicolumn{2}{|c|}{$\begin{array}{l}\text { Sensitivity } \\
\text { Range }\end{array}$} & $\begin{array}{l}\text { Base } \\
\text { Case }\end{array}$ & \multicolumn{2}{|c|}{$\begin{array}{l}\text { Sensitivity } \\
\text { Range }\end{array}$} & $\begin{array}{l}\text { Base } \\
\text { Case }\end{array}$ & \multicolumn{2}{|c|}{$\begin{array}{l}\text { Sensitivity } \\
\text { Range }\end{array}$} \\
\hline \multicolumn{12}{|l|}{$\begin{array}{l}\text { OPEC } \\
\text { Persian Gulf }\end{array}$} \\
\hline $\operatorname{Iran} \ldots \ldots$ & 3.2 & 3.6 & 4.6 & 4.3 & 5.0 & 5.1 & 4.8 & 5.8 & 5.5 & 5.0 & 6.2 \\
\hline$\ldots \ldots \ldots \ldots \ldots \ldots$ & 2.2 & 0.4 & 4.7 & 4.0 & 5.5 & 5.5 & 4.7 & 6.5 & 6.7 & 6.0 & 7.2 \\
\hline$\ldots \ldots \ldots$ & 1.7 & 1.1 & 3.1 & 3.0 & 3.3 & 3.8 & 3.6 & 4.5 & 4.6 & 4.0 & 5.1 \\
\hline Qatar .................. & 0.5 & 0.4 & 0.6 & 0.5 & 0.7 & 0.6 & 0.5 & 0.7 & 0.6 & 0.5 & 0.6 \\
\hline Saudi Arabia $\ldots \ldots \ldots \ldots$ & 8.5 & 9.6 & 11.0 & 10.5 & 12.3 & 13.1 & 11.3 & 14.0 & 13.9 & 12.0 & 14.7 \\
\hline United Arab Emirates $\ldots \ldots \ldots$ & 2.5 & 2.6 & 3.2 & 2.9 & 3.4 & 4.3 & 4.0 & 4.8 & 4.6 & 4.0 & 5.2 \\
\hline Total Persian Gulf ......... & 18.6 & 17.7 & 27.2 & 25.2 & 30.2 & 32.4 & 28.9 & 36.3 & 35.9 & 31.5 & 39.0 \\
\hline \multicolumn{12}{|l|}{ Other OPEC } \\
\hline 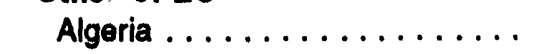 & 1.4 & 1.3 & 1.6 & 1.4 & 1.9 & 1.3 & 1.0 & 1.5 & 1.1 & 0.9 & 1.6 \\
\hline Gabon ................ & 0.3 & 0.3 & 0.3 & 0.3 & 0.4 & 0.3 & 0.2 & 0.3 & 0.3 & 0.2 & 0.3 \\
\hline Indonesia............... & 1.5 & 1.7 & 1.4 & 1.2 & 1.6 & 1.2 & 1.0 & 1.4 & 1.1 & 0.8 & 1.4 \\
\hline Libya ................. & 1.6 & 1.6 & 2.0 & 1.8 & 2.3 & 2.2 & 1.9 & 2.4 & 2.3 & 2.0 & 2.6 \\
\hline Nigeria $\ldots \ldots \ldots \ldots \ldots \ldots$ & 1.8 & 2.0 & 2.5 & 2.3 & 2.7 & 2.7 & 2.5 & 2.9 & 2.9 & 2.5 & 3.1 \\
\hline Vonezuela .............. & 2.6 & 2.6 & 3.4 & 3.0 & 3.9 & 4.0 & 3.7 & 4.3 & 4.2 & 3.8 & 4.7 \\
\hline Tofal Other OPEC ......... & 9.2 & 9.5 & 11.2 & 10.0 & 12.8 & 11.7 & 10.3 & 12.8 & 11.9 & 10.2 & 13.7 \\
\hline Total OPEC $\ldots \ldots \ldots \ldots \ldots$ & 27.8 & 27.2 & 38.4 & 35.2 & 43.0 & 44.1 & 39.2 & 49.1 & 47.8 & 41.7 & 52.7 \\
\hline \multirow{2}{*}{\multicolumn{12}{|c|}{$\begin{array}{l}\text { Non-OPEC } \\
\text { OECD }\end{array}$}} \\
\hline & & & & & & & & & & & \\
\hline United States & 9.7 & 9.7 & 8.0 & 7.6 & 8.3 & 7.8 & 6.6 & 8.1 & 8.1 & 6.4 & 8.8 \\
\hline Canada .... & 2.0 & 2.1 & 2.2 & 2.1 & 2.3 & 2.5 & 2.0 & 2.5 & 2.5 & 1.9 & 2.6 \\
\hline Australia. & 0.7 & 0.6 & 0.9 & 0.7 & 1.0 & 0.7 & 0.6 & 0.8 & 0.6 & 0.5 & 0.6 \\
\hline North Sea .. & 4.2 & 4.6 & 5.9 & 5.8 & 6.0 & 4.9 & 4.5 & 5.0 & 4.4 & 4.0 & 4.4 \\
\hline Other OECD & 0.5 & 0.5 & 0.5 & 0.5 & 0.5 & 0.4 & 0.4 & 0.5 & 0.4 & 0.3 & 0.4 \\
\hline Total OECD . . . . . . . . . & 17.1 & 17.5 & 17.5 & 16.7 & 18.1 & 16.3 & 14.1 & 16.9 & 16.0 & 13.1 & 16.8 \\
\hline \multicolumn{12}{|l|}{ Eurasia } \\
\hline China ............ & 2.8 & 2.8 & 3.5 & 3.4 & 3.6 & 3.5 & 3.2 & 3.9 & 3.5 & 2.9 & 3.8 \\
\hline Former Soviet Union ... & 11.5 & 9.1 & 8.2 & 7.4 & 9.1 & 9.6 & 8.4 & 11.3 & 11.1 & 8.4 & 11.8 \\
\hline Eastern Europe . . . . . . . . & 0.3 & 0.2 & 0.2 & 0.2 & 0.3 & 0.2 & 0.1 & 0.2 & 0.2 & 0.1 & 0.2 \\
\hline Total Eurasia....$\ldots \ldots$ & 14.6 & 12.1 & 11.8 & 11.0 & 13.0 & 13.3 & 11.7 & 15.4 & 14.8 & 11.4 & 15.8 \\
\hline \multicolumn{12}{|l|}{ Other Non-OPEC } \\
\hline Latin America .. & 5.2 & 5.5 & 6.4 & 6.0 & 6.8 & 6.1 & 5.8 & 6.5 & 6.0 & 5.6 & 6.2 \\
\hline Middle East ............. & 1.4 & 1.5 & 1.9 & 1.8 & 2.3 & 1.8 & 1.5 & 2.0 & 1.8 & 1.5 & 2.0 \\
\hline Africa $\ldots \ldots \ldots \ldots \ldots \ldots$ & 1.8 & 1.9 & 1.8 & 1.5 & 2.0 & 1.6 & 1.4 & 1.9 & 1.5 & 1.3 & 1.7 \\
\hline Asia ................. & 1.7 & 1.7 & 2.4 & 2.1 & 2.8 & 2.4 & 2.0 & 2.6 & 2.3 & 2.0 & 2.5 \\
\hline Total Other Non-OPEC ..... & 10.1 & 10.6 & 12.5 & 11.4 & 13.9 & 11.9 & 10.7 & 13.0 & 11.6 & 10.4 & 12.4 \\
\hline Total Non-OPEC $\ldots \ldots \ldots \ldots$ & 41.8 & 40.2 & 41.9 & 39.1 & 45.0 & 41.5 & 36.5 & 45.3 & 42.4 & 34.9 & 45.0 \\
\hline World Total $\ldots . . \ldots \ldots \ldots \ldots$ & 69.6 & 67.4 & 80.3 & 74.3 & 88.0 & 85.6 & 75.7 & 94.4 & 90.2 & 76.6 & 97.7 \\
\hline
\end{tabular}

OPEC = Organization of Petroleum Exporting Countries.

OECD = Organization for Economic Cooperation and Development.

Notes: Capacity is defined as maximum sustainable production capacity adjusted to reflect current operable capacity in selected onuntries. Production includes crude oil, natural gas liquids, refinery gains, hydrogen, and other hydrocarbons. Totals may not equal sitm of components because of independent rounding.

Sources: Estimates-Energy Information Administration (EIA), Energy Markets and Contingency Information Division. Projections-EIA, Oi' Market Simulation Model Spreadsheet, 1994. 


\section{Measuring OPEC Dependence}

The increased dependence on Persian Gulf oil reinforces concerns about energy security, so the possibility of oil supply disruptions and volatile oil prices will continue to worry oil importers worldwide. Since the world oil market is an integrated one, disruptions in any significant area are reflected at once in changes everywhere. Security concerns, particularly among the industrialized OECD countries that import large quantities of oil, can influence policies aimed at diversifying energy supplies and at encouraging more efficient use of oil, particularly in the transportation sector where most oil is consumed.

The degree of energy weakness or strength is not only a matter of dependence on a particular supply source, but is the contrast between global dependence on a concentrated supply source and the availability of supply-disruption offsets such as excess oil production capacity and petroleum stocks. Other factors-such as political and economic stability, the ability to quickly substitute other fuels, and the ability to distribute available oil-are not only difficult to quantify, but can also influence the security of supplies.

While the complexities associated with this subject make measuring energy security and world dependence on the OPEC oil supply difficult, the index presented in Figure 20 attempts to demonstrate the extent to which the world is susceptible to potential disruptions. The index is constructed to show only relative measures of

\section{Figure 20. World Dependence on OPEC OII,} 1973-2010

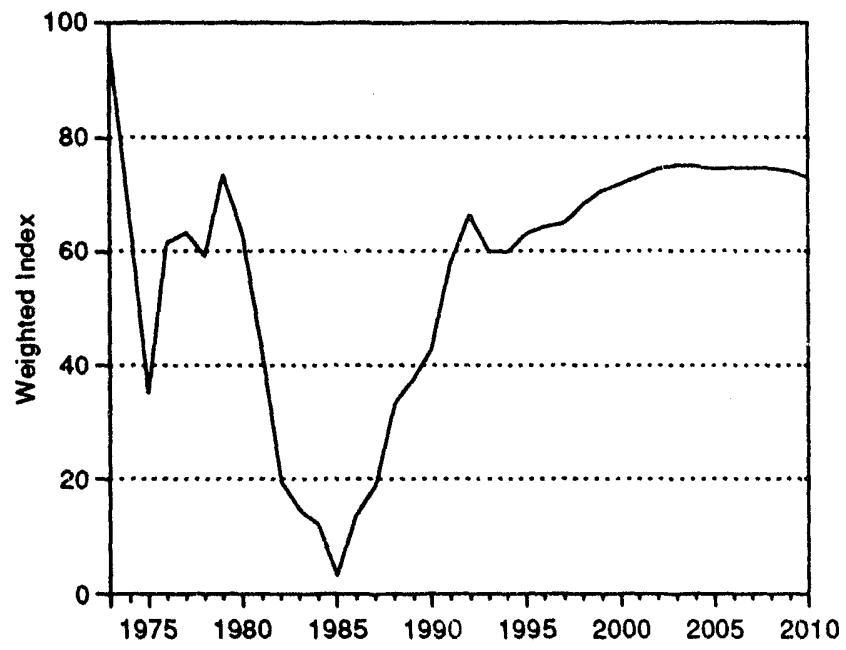

Note: See Appendix B for methodology.

Source: Energy Information Administration, Office of Integrated Analysis and Forecasting, Energy Demand and Integration Division. dependence. $A$ higher index indicates that the world is relatively more dependent on the OPEC oil supply and thus, more likely to experience large increases in prices as a result of a disruption than when the index is lower. That is, the larger the index value, the greater the probability of experiencing large price increases and the greater the impact on the economy. The index characterizes past and future market conditions, accounting for:

- OPEC market share-the percent of world oil demand supplied by OPEC

- OECD oil stock levels-the level of stocks at the end of the year in OECD countries, including strategic stocks expressed in terms of days of supply

- Excess OPEC crude oil production capacity-production capacity in OPEC minus actual production.

Figure 20 summarizes the index of OPEC dependence for the period 1973 through 2010. The index was computed using these three variables which were combined, by assumption, using a weighted average of 50 percent for excess capacity, 30 percent for OPEC market share, and 20 percent for available stocks. It is important to note that, because these variables generally follow similar patterns, the use of another weighting scheme would make little difference (see Appendix B). The more dependent the world is on OPEC oil, the more likely it is that a disruption of supplies from this region would affect world markets. Conversely, high levels of oil stocks (including strategic reserves held by the United States, Japan, and Germany) can counter or limit the impact of a disruption and may even make such an event less likely.

The availability of excess crude oil production capacity to counter the effect of a disruption is critical. During the Persian Gulf War, for example, Saudi Arabian excess capacity and about $\mathbf{1 7}$ million barrels of oil from U.S. strategic reserves were used to help counter the impact of the disruption and greatly reduced the potential economic damage. A basic aim of the International Energy Agency (IEA), an autonomous body within the framework of the OECD, has been to develop and maintain an International Energy Program (IEP) to prepare participating countries against the risk of major oil supply disruptions and to share the oil that is available in the event of an emergency [28, p. 2]. Allocation rights and obligations are specified in an IEP-sharing formula, which the IEA may trigger. To date, the IEP has not been activated.

Oil consumers experienced a relatively secure period in the late $1980^{\prime} \mathrm{s}$ because of excess production capacity 
and high stock levels. Concern jumped in the early 1990's, however, when supplies from Iraq and Kuwait were disrupted. This period has been followed by one of relatively abundant oil supplies, but dependence on OPEC is expected to increase again and by 2010 to be much closer to the level experienced in the early 1970's. This dependency will occur to the extent that nonOPEC production peaks and world demand for OPEC oil increases.

\section{The Impact of an OIl Supply Disruption}

Over the past 20 years three major oil supply disruptions have occurred. The first was in 1973 when the Arab-Israeli war triggered the Arab oil embargo. The second coincided with the Iranian revolution in 1978-79, and the most recent was associated with the Iraqi invasion of Kuwait in 1990. Sharp increases in oil prices were associated with each of these events. In addition, these price increases sometimes triggered increases in overall consumer prices and declines in GDP. For these reasons the potential impacts of supply disruptions continue to concern policymakers and others interested in energy markets. The purpose of this section is not to predict the precise impacts of a supply disruption but to outline possible reactions to several hypothetical disruptions. While it is not possible to predict the timing, size, and duration of a disruption, these assumptions are necessary to develop a meaningful disruption scenario.

The analysis of the impacts of an oil supply disruption is based on several alternative assumptions about the magnitude, timing, and response to the disruption:

- Three different levels of supply disruptions in the Persian Gulf-4, 6, and 8 million barrels per day (MMBD)-were evaluated, with the disruption assumed to take place in 2000. The 4-MMBD loss of supplies is comparable to the historical experience during the 1990 Persian Gulf War. The 8-MMBD disruption would be much larger than any the world has previously faced; while such an event is considered unlikely, it could occur as the result of major military action or social upheaval. The use of the year $\mathbf{2 0 0 0}$ is arbitrary. Over the past 20 years, a major supply disruption has occurred every 7 to 10 years.

- The disruptions are assumed to last 6 months for the 4-MMBD disruption, either 6 or 9 months for the 6-MMBD disruption, and 9 months for the 8MMBD disruption. While the duration of supply disruptions can vary, these assumptions are consistent with a major supply disruption caused by some political event that is not easily resolved.
- About $2 \mathrm{MMBD}$ of the original disruption is offset by the use of excess capacity from other sources. In the past, disruptions typically have been somewhat offset by the use of surge capacity from nondisrupted sources. For example, in the Persian Gulf War, Saudi Arabia greatly increased production to offset some of the declines in production from Kuwait and Iraq. This 2-MMBD figure is consistent with excess capacity figures assumed in the Base Case projections contained in this report.

- Prices are assumed to return to Base Case levels within a year after the disruption has ended, reflecting the fact that markets do not instantly adjust to a new production environment. Tanker sailing times and stock rebuilding could all contribute to the delay in returning to Base Case levels.

- For each level and length of supply disruption, two cases are considered involving the use of strategic stocks. In one case, it is assumed that no strategic stocks are used. In the second, it is assumed that the U.S. Strategic Petroleum Reserve (SPR) is drawn down by the maximum amount possible during the disruption, but not exceeding the net disruption. The maximum drawdown rates assumed in this analysis are 3.5 MMBD in the first quarter, 1.1 MMBD in the second quarter, and 0.5 MMBD in the third quarter of the disruption. For purposes of this analysis, it is assumed that the strategic stocks in Japan and Germany are not drawn down. These two contrasting cases illustrate the potential impact of using the SPR during a disruption.

- The range of impacts for the SPR and No SPR cases is based on alternative assumptions concerning private stock changes and demand elasticities. Assumptions of a 1.0-MMBD inventory build and relatively low demand elasticities result in higher prices and higher economic impacts compared to assumptions of 1.0-MMBD inventory draw and higher demand elasticities.

The impacts of the various disruptions on annual oil prices for 1990 are shown in Figure 21. The 4-MMBD disruption, with a high elasticity of response, has a price rise of $\$ 2.40$ per barrel if the SPR is not used. Using the SPR would totally compensate for this disruption, leaving prices unchanged. For the worst disruption analyzed ( 8 MMBD, 9 months duration, and low elasticity of response), the price increases to $\$ 54.50$ per barrel with no SPR drawdown. Use of the SPR would lower the price to $\$ 45.00$, a difference of almost $\$ 10$ per barrel. In all cases, the use of the U.S. SPR to offset some of the disruption in supplies significantly reduces the impact of the disruption. 
Figure 21. Price Impacts of an Oll Supply Disnuption, 2000

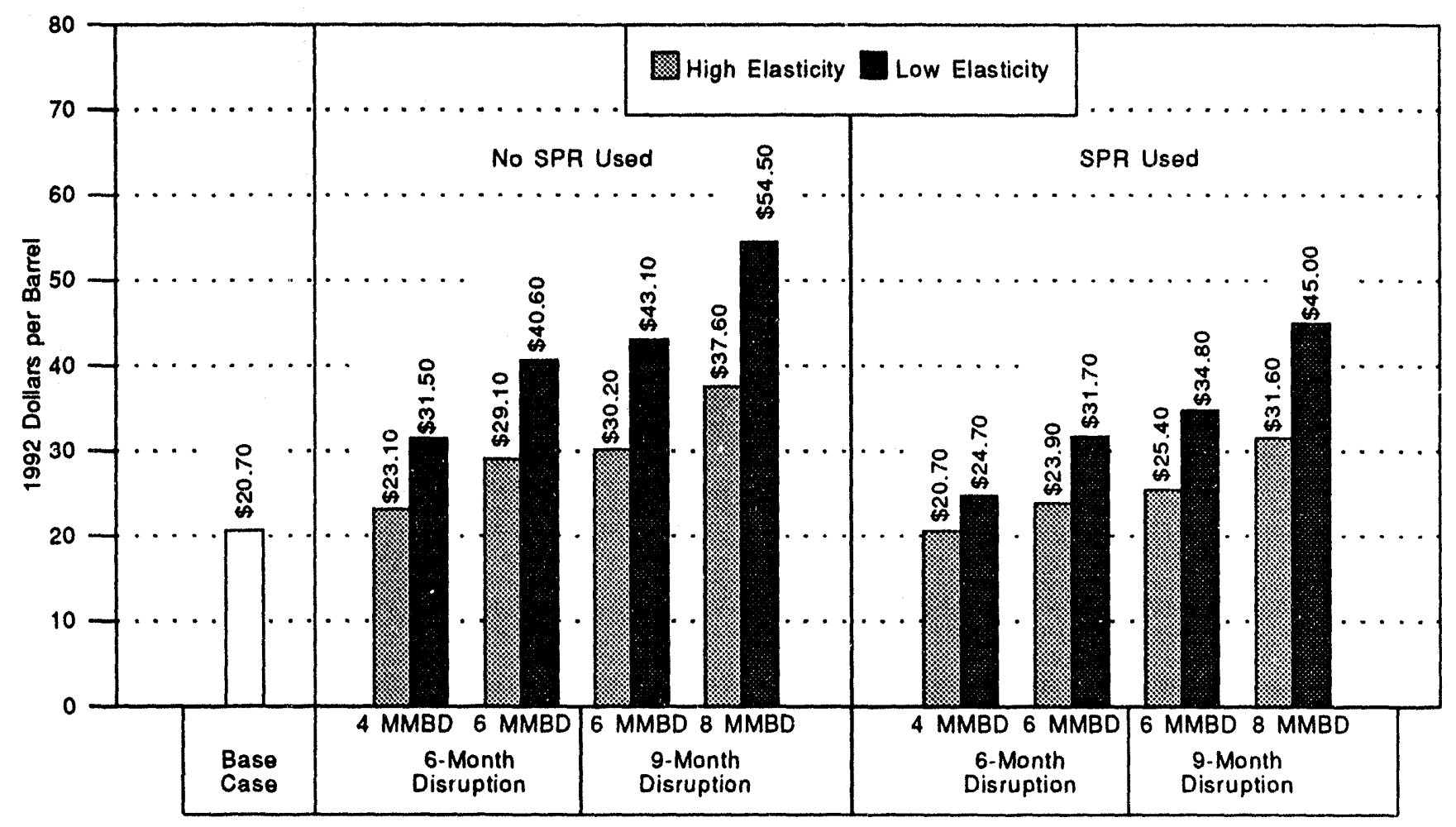

SPR = Strategic Petroleum Reserve. MMBD = million barrels per day.

Source: Energy Information Administration, Disruption Impact Simulator, DISY2000.WK1.

When consumers are faced with rapid increases in energy prices, they can respond in a number of ways. Some consumers will choose to turn down thermostats and use more wood in an effort to avoid paying higher heating bills. Others will forego purchases of energyintensive goods, while even others will choose alternative ways of getting to work or driving their more efficient vehicles more frequently.

Historically, supply disruptions have been associated with more negative impacts than just an increase in petroleum prices. Typically, major supply disruptions have also been associated with increases in consumer prices, increased unemployment, and a decline in gross domestic product (GDP). A smaller disruption (4 MMBD), coupled with a higher elasticity of response and the use of the Nation's SPR, would result in no loss in GDP. At the other end of the spectrum, if the economy were to experience a 9-month disruption of large magnitude (8 MMBD), assuming that consumers have a low elasticity of response to the petroleum price change, the annual loss of GDP could be as high as $\$ 98$ billion. Between these two extremes, the following observations hold. The use of the SPR helps to ameliorate the price shock and the impact on GDP. In the 8MMBD case, use of the SPR lowers the GDP impact from $\$ 98$ billion to $\$ 65$ billion, a difference of $\$ 34$ billion. The demand elasticity of the response is also important. If consumers reduce their use of petroleum products at a faster pace (high elasticity case) and SPR stocks are also drawn down, the GDP impact is reduced by an additional $\$ 38$ billion. Use of strategic stocks held by U.S. allies, which is not assumed in this analysis, would further reduce the price and economic impacts of a disruption. 


\section{Natural Gas}

Natural gas should become a more important fuel as consumers look for stable, environmentally friendly sources of energy.

Increased reliance on natural gas will be driven by economic, environmental, and energy security factors. Natural gas burns more cleanly than oil or coal. Because of the diversity of suppliers and the absence of a cartel to control supplies and prices, natural gas is also a relatively secure source of energy.

Worldwide consumption of natural gas is projected to increase by 56 percent between 1990 and 2010 (Figure 22). This energy source is likely to rival coal as the runner-up to oil in global importance (Figure 11 on page 8). The highest growth rates for natural gas consumption are expected to occur in the developing countries of the world; but the countries of the Organization for Economic Cooperation and Development (OECD) and Eurasia (especially Russia) should also make steady gains (Figure 23 and Table A4 in Appen$\operatorname{dix} A$ ).

Consumption of natural gas by the Rest of World (ROW) countries, excluding members of the Organiza-

Figure 22. Total World Natural Gas Consumption, 1980-2010

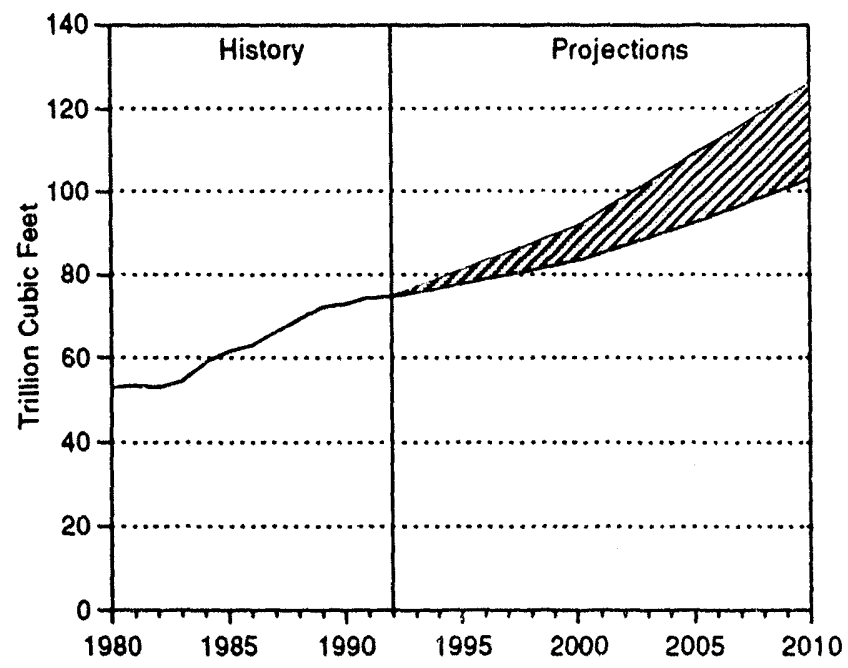

Sources: History: Energy Information Administration, International Energy Annual 1992, DOE/EIA-0219(92), Table 9 and related data base. Projections: Table A4. tion of Petroleum Exporting Countries (OPEC), should rise an average of 5.5 percent per year between 1990 and 2010, more than twice as fast as the average annual global growth rate for gas of 2.3 percent. OECD's share in world natural gas consumption is expected to decline, yet remain a substantial part of the worldwide total (Figure 24). The Eurasia share of world natural gas consumption in Figure 24 reflects rapid growth in the former Soviet Union (FSU) during the 1980's, then little or no growth in consumption until after 2000 . As with all energy sources projected over such a long period, Figure 23 shows that there are considerable ranges of uncertainty for this fuel.

With abundant supplies throughout the world, the natural gas supply should be sufficient to cover growing demands. Bottlenecks that might develop would most likely be caused by problems with transporting the gas, which requires large investment. If gas prices remain consistently low, investment in exploration and development could be discouraged.

Figure 23. World Natural Gas Consumption by Major Country Groupings, 1980-2010

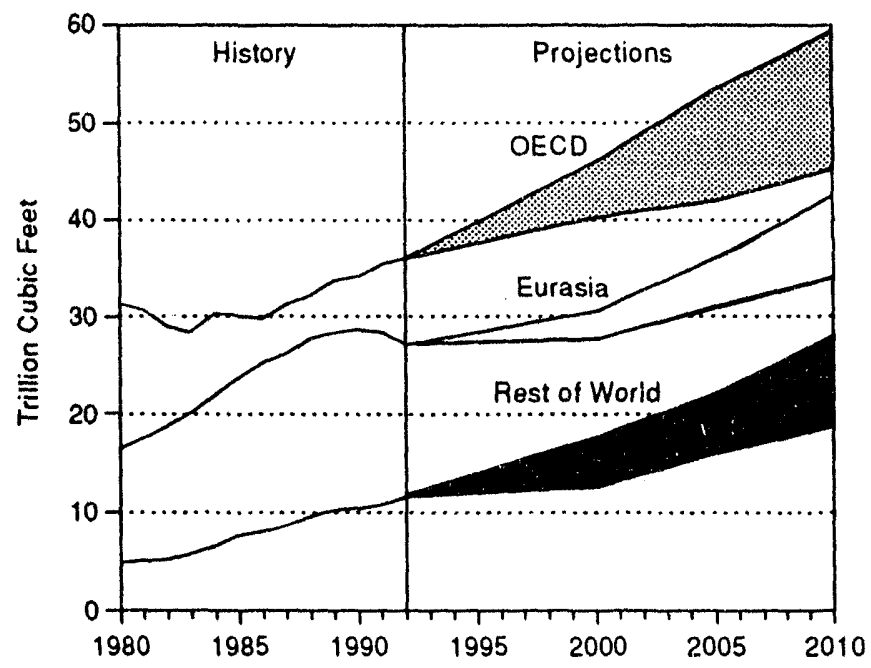

Sources: History: Energy Information Administration, International Energy Annual 1992, DOE/EIA-0219(92), Table 9 and related data base. Projections: Table A4. 
Figure 24. Share of Natural Gas Consumption by Major Country Groupings, 1980-2010

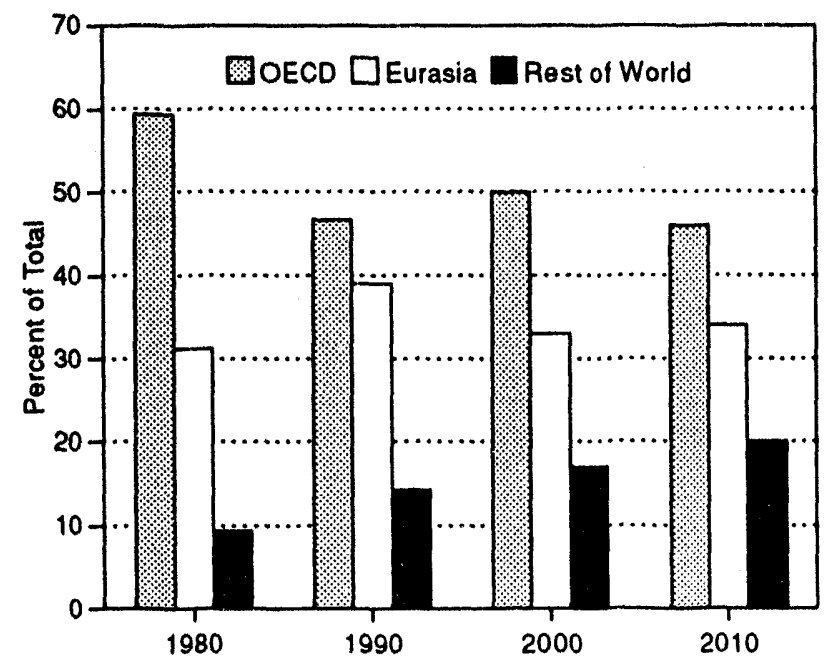

Sources: History: Energy Information Administration, International Energy Annual 1992, DOE/ElA-0219(92), Table 9 and related data base. Projections: Table A4.

\section{Reserves}

World gas reserves are estimated at approximately 5,016 trillion cubic feet (Tcf), with the FSU accounting for nearly 40 percent of this total (Table 7). On a regional basis, Eurasia and the Middle East together account for almost three-fourths of all reserves. The remaining one-fourth is fairly evenly distributed among other world regions-North America, Central and South America, Western Europe, Africa, and Asia/ Pacific (Figure 25).

Almost all of the countries with large known gas reserves are also major oil producers. Of the ten countries with the largest gas reserves, eight are members of OPEC, and all except Qatar and Iraq produced over 1 million barrels of oil per day in 1992 [11, p. 6]. Iraqi production was curtailed by political factors. Demand and financial constraints will limit the ability of all countries to take full advantage of abundant reserves in the near future, but some may use gas as a substitute for oil in satisfying domestic energy demand-thereby allowing larger oil exports.

\section{Pipeline and Liquefied Natural Gas Trade}

In international trade, natural gas is transported either by pipeline or, in the case of liquefied natural gas (LNG), by ship. Because it is extracted in a gaseous state, this fuel is much more difficult to transport than either oil or coal-which are extracted in liquid and solid states, respectively. Pipelines are the transport
Table 7. World Natural Gas Reserves (Trillion Cubic Feet)

\begin{tabular}{|c|c|c|}
\hline Country & Reserves & $\begin{array}{l}\text { Percent } \\
\text { of Total }\end{array}$ \\
\hline \multicolumn{3}{|l|}{ Top 20 Countries } \\
\hline $\begin{array}{l}\text { Former Soviet Union } \ldots \ldots \\
\text { Iran } \ldots \ldots \ldots \ldots \\
\text { Qatar } \ldots \ldots \ldots \ldots \ldots \ldots \\
\text { United Arab Emirates } \ldots \ldots\end{array}$ & $\begin{array}{r}1,997.0 \\
730.0 \\
250.0 \\
204.6\end{array}$ & $\begin{array}{r}39.8 \\
14.6 \\
5.0 \\
4.1\end{array}$ \\
\hline $\begin{array}{l}\text { Saudi Arabia } \ldots \ldots \ldots \ldots \\
\text { United States } \ldots \ldots \ldots \ldots \\
\text { Venezuela } \ldots \ldots \ldots \ldots \\
\text { Algeria } \ldots \ldots \ldots\end{array}$ & $\begin{array}{l}185.4 \\
165.0 \\
128.9 \\
128.0\end{array}$ & $\begin{array}{l}3.7 \\
3.3 \\
2.6 \\
2.6\end{array}$ \\
\hline $\begin{array}{l}\text { Nigeria } \ldots \ldots \ldots \ldots \ldots \\
\text { Iraq } \ldots \ldots \ldots \ldots \ldots \\
\text { Canada } \ldots \ldots \ldots \ldots \ldots \ldots \\
\text { Malaysia } \ldots \ldots \ldots \ldots \ldots\end{array}$ & $\begin{array}{r}120.0 \\
109.5 \\
94.8 \\
76.7\end{array}$ & $\begin{array}{l}2.4 \\
2.2 \\
1.9 \\
1.5\end{array}$ \\
\hline $\begin{array}{l}\text { Mexico } \ldots \ldots \ldots \ldots \ldots \\
\text { Norway } \ldots \ldots \ldots \ldots \ldots \ldots \\
\text { Netherlands } \ldots \ldots \ldots \ldots \ldots \\
\text { Indonesia } \ldots \ldots \ldots \ldots \ldots \ldots\end{array}$ & $\begin{array}{l}71.0 \\
70.5 \\
68.2 \\
64.4\end{array}$ & $\begin{array}{l}1.4 \\
1.4 \\
1.4 \\
1.3\end{array}$ \\
\hline $\begin{array}{l}\text { China } \ldots \ldots \ldots \ldots \ldots \ldots \\
\text { Kuwait } \ldots \ldots \ldots \ldots \ldots \ldots \\
\text { Libya } \ldots \ldots \ldots \ldots \ldots \ldots \\
\text { Argentina } \ldots \ldots \ldots \ldots \ldots \ldots\end{array}$ & $\begin{array}{l}59.0 \\
52.4 \\
45.8 \\
26.5\end{array}$ & $\begin{array}{l}1.2 \\
1.1 \\
0.9 \\
0.5\end{array}$ \\
\hline Total, Top $20 \ldots \ldots$ & $4,647.7$ & 92.7 \\
\hline All Other Countries . . . . . . & 368.5 & 7.3 \\
\hline World Total . . . . . . . . . & $5,016.2$ & 100.0 \\
\hline
\end{tabular}

Source: Oil and Gas Journal, Vol. 91, No. 52 (December 27, 1993), pp. 44-45.

Figure 25. Natural Gas Reserves

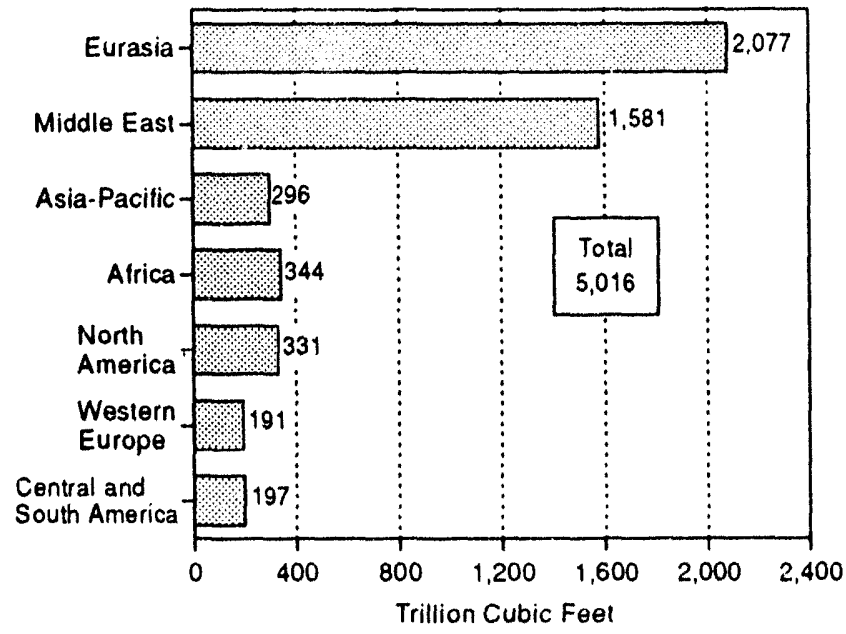

Source: Oil and Gas Journal (December 27, 1993), pp. 44-45. 
mode of choice, but their use is not without some problems. Running pipelines from producing gas fields to consumers is expensive, especially over long distances, and it is economically prohibitive to run pipelines across many bodies of water, which isolate major suppliers such as Indonesia and Australia from major consumers such as Japan. However, using LNG reduces some of these problems.

Once natural gas has been converted at low temperature to a liquid state, it can be loaded onto specially designed, refrigerated ships and delivered to ports anywhere in the world that are equipped with the necessary receiving facilities, then distributed further by pipeline as required. The drawback to LNG is that the conversion process, the ships themselves, the handling, and the specialized facilities needed add considerably to the fuel's expense-reducing its economic attractiveness to distant customers as compared with oil and coal.

The price of oil is a key factor in determining whether, where, and when new pipelines and LNG facilities are to be built. If oil prices stay low, competition between these two fuels among end users will make it difficult for gas prices to rise. While this prospect is good for the consumer, it is discouraging to potential investors in capital-intensive new gas-transport structures; they will be unwilling to undertake financial risk unless they can foresee acceptable and reasonably prompt returns from the market. There are a number of projects throughout the world, most notably a pipeline project from Russian Siberia to Europe, whose fate may depend on the price of oil. By the end of the century, however, a variety of projects currently underway to facilitate natural gas trade are expected to be operational. For example, LNG export programs in Oman, Qatar, and Nigeria will, if successful, make these countries new suppliers to Europe and the Pacific region.

International gas trade is likely to remain about threequarters by pipeline delivery and one-quarter by LNG [47, p. 26]. The overall volume traded should increase with higher demand for gas around the world and projected increases in the price of oil.

\section{Regional Prospects}

With plentiful natural gas reserves and given adequate investment in the gas transport infrastructure, there should be no overall shortage of world supply from now through 2010. The existence of numerous, dispersed suppliers provides added reliability, and many consuming regions could be self-sufficient if necessary.
North America: Even with rapidly increasing demand, there should be no problems with gas supply in this region during the next two decades. The market in North America is mature and essentially self-sufficient, with most gas moving through a vast continental pipeline system. The bulk of the regional trade is directed from Canada to the United States. In recent years the United States has exported a small amount of gas to Mexico, but this net flow will probably reverse over the next 10 to 20 years. The United States has imported a small amount of LNG in the past and should continue to import LNG through 2010 [8, p. 33].

Pressures for environmental protection, energy security, and low cost virtually ensure that consumption of natural gas will continue to rise in North America, both in absolute value and in its share of the continental energy market (see box). Demand in Canada and the United States is expected to grow about 30 percent over the twenty year period between 1990 and 2010. Even with relatively low growth rates for the period, the United States and Canada combined should still account for more than half of all OECD gas consumption in 2010.

South America: Venezuela has by far the largest reserves of natural gas in South America. Its $129 \mathrm{Tcf}$ represent about 5 times as much gas potential as second-place Argentina. The only major current project under way in South America is a Venezuelan LNG plant (Cristobal Colon), designed to permit exports to the Caribbean, the United States, and the rest of North America. This project is making its way through the Venezuelan Congress, but is unlikely to be operational for many years $[25$, p. 11].

Former Soviet Union: While Russia will almost certainly become a major supplier of gas to Europe in the long run, disputes between Russia and Ukraine about transportation and prices could delay large quantities of Russian gas from reaching the rest of Europe in the near term. Because pipelines from Western Siberia pass through Ukraine to reach Russia's European customers, the Ukraine has the ability to cut off Russian gas exports to Europe, and Russia has the ability to cut off its gas supply to Ukraine. Ukraine depends on Russian gas, but this newly independent part of the FSU will find it difficult to pay the Western European prices Russia has been asking. For its part, Russia is not interested in supplying Ukraine with gas at less than market value, but it needs the hard currency promised by the gas sales. Gas companies of the two countries came to an agreement last summer over prices and pipeline use. In the agreement, Ukraine will pay Russia in hard currency for the gas it imports. The price was 


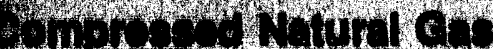

De erivironmental concems move the transportation sector toward cleaner vehicles, compressed natural gas (dNa) will probably become more prominent as a transportation fuel. CNG burns more cleanly in automobiles than ersoline and alcohol-based fuels, while performance levels are equivalent [6, p. 154]. Growth of CNG as C transportation fuel may be slowed by two drawbacks: low driving range between refueling stops in comparison with gasoline vehides, and the lack of a supporting natural gas infrastructure, including a current 1 d of CNG refueling stations.

Whiough many countries and companies worldwide are inyolved now in CNG, the ratio of CNG vehicles to cheoline vehicles is still very small. The countries with the largest number of CNG vehicles are [7, p. 38]:

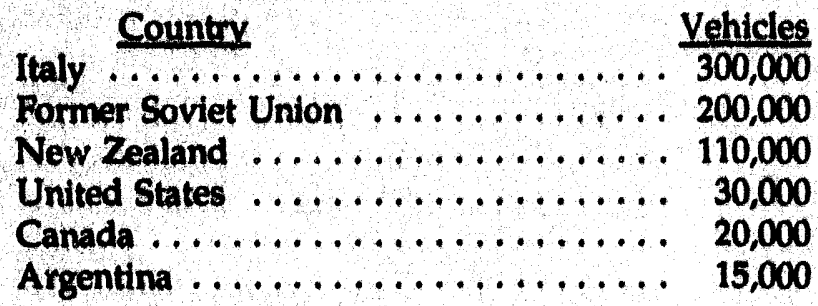

Taly has the largest number of CNG-powered automobiles, having used them since 1935. The former Soviet Union and New Zealand also have relatively large fleets. Projects to increase vehicular use of natural gas are underway in Brazil, Australia, and Belgium. For both technical and economic reasons, most such projects involve the public transportation sector, buses and taxis, and other fleet vehicles [14, p. 30;15, p. 30; and 17, p. 25]. Russia has plans to increase its number of natural gas vehicles to almost 400,000 by the end of 1997 with 1.5 hope of cutting petroleum consumption [16, p. 26].

set below market value for 1993 and at market value by 1994. In return for use of its pipelines, Ukraine will receive a quantity of gas at no charge [25, pp. 7-8].

Russia could seek an alternate route by building new pipelines along a more northern route to serve Europe from its major gas fields in the Yamal Peninsula, thus avoiding Ukraine by going through Belarus and Poland; but this would require massive pipeline investments and would not avoid border crossings. Low gas prices resulting from currently low oil prices are likely to discourage investors in such a pipeline $[25, \mathrm{p}$. 9].

By the year 2010, natural gas could account for almost half of all energy consumed in the FSU (Figure 26). Consumption within the FSU is expected to grow by approximately 32 percent between 1990 and 2010, primarily because Russia will use its vast resource base to spur economic growth. Between 1990 and 1995, demand for gas there is likely to stagnate, as parts of the FSU struggle to stabilize their economies and all energy consumption declines. From 1995 through 2010, however, gas demand is expected to resume an annual average growth rate of about 2 percent.
Flgure 26. Natural Gas Consumption as a Percentage of Total Energy Consumption, 1980-2010

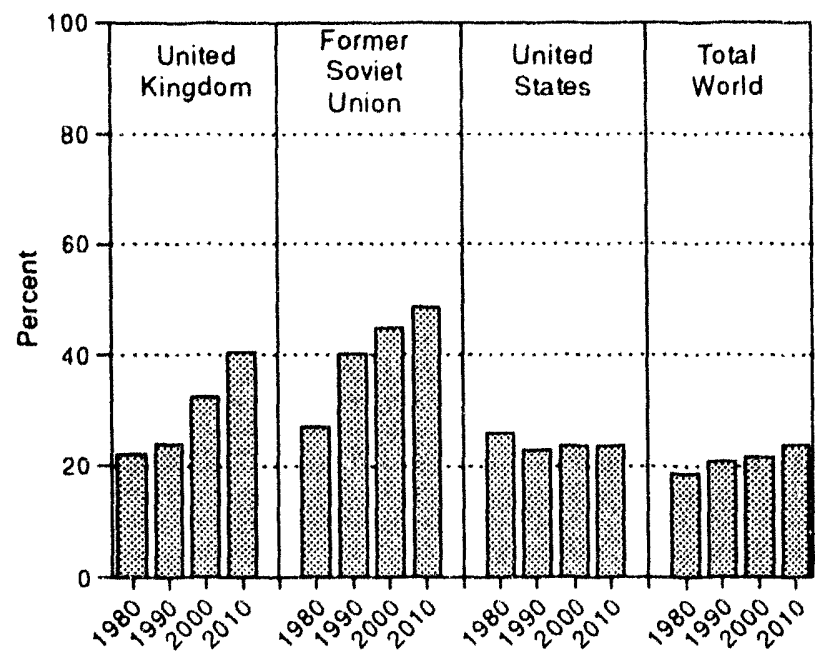

Sources: History: Energy Information Administration (EIA), International Energy Annual 1992, DOE/EIA-0219(92), Tables A9 and A11 and related data base. Projections: EIA, World Energy Projection System, 1994. 
Europe: Most of Europe has relatively small gas reserves, yet its prospects for a secure and stable supply of gas are good because of the diversity of suppliers. Norway, Algeria, Russia, Oman, Qatar, and possibly other Middle Eastern countries are potential suppliers. In 1990 natural gas accounted for 16 percent of total European energy consumption, and by 2010 it is expected to be 25 percent. In absolute terms, consumption of natural gas in Europe is expected to nearly double between 1990 and 2010.

Norway has the largest gas reserves in Europe, with the potential of remaining a major European supplier for the next two decades. In late 1993 the Zeepipe pipeline began transporting gas from some of Norway's North Sea gas fields to Zeebrugge, Belgium, for distribution to a number of European countries [24, p. 6]. Any projects to increase production and trade further in this area would require substantial investment to make connections to current export pipelines. Higher oil prices or any instability in other supply regions would increase the likelihood of such investment.

Africa/Middle East: Algeria's gas fields are already connected to Southern Europe via the Trans-Mediterranean Pipeline that terminates in Italy, and Algeria also ships LNG to a number of countries. Its large reserves and the pipelines and LNG plants that already exist there can probably make it a reliable source of gas for Europe for many years. Any problems with the supply of Algerian gas would likely be caused by political instability, a concern heightened by the current struggle between the government and Islamic fundamentalists.

Nigeria has been in the process of planning an LNG plant and export facilities to take advantage of a growing LNG market and plentiful Nigerian gas; but recent political problems have discouraged investors and delayed the approval of loans necessary to start the project. If these problems are resolved shortly, the project could be completed by 1997. It is also possible that government interference could ruin the project altogether [57, p. 34].

In the Middle East, Oman and Qatar are pursuing projects to export LNG. Each has the support of its respective government, and both have substantial investment by western companies. Barring problems, both countries should begin exporting LNG to Europe and Asia by the end of the century [23, pp. 49-50, and 54, pp. 13-14]. Oman's location-outside the Straits of
Hormuz, and thus beyond the Persian Gulf itselfmakes it more desirable as a trading partner to countries like Japan, which rely almost entirely on imported energy and try to minimize the supply disruptions caused by regional conflicts [54, pp. 13-14].

Asia/Pacific: The Asia/Pacific region as a whole has a gas transportation infrastructure that is less developed than that of either Europe or North America. Countries with indigenous reserves-such as Indonesia, Malaysia, and Australia-are currently making investments in their respective natural gas industries for both domestic use and exports. Domestically, Indonesia and Malaysia are investing in gas for a number of reasons, including electricity generation, for use in the petrochemical industry as a feedstock, for synthesizing middle distillates such as diesel and kerosene, and as a revenuegenerating export, primarily in the form of LNG [19, pp. 108-109, and 25, p. 11].

Japan, South Korea, and Taiwan are major gas importers in this region, almost exclusively in the form of LNG because of the large sea-distances that separate them from supplying countries. Given the geography of the region, the LNG trade is expected to grow with Japan remaining the regional and world leader in LNG imports. Some Japanese companies have begun to make deals with LNG suppliers like Oman and Qatar outside the Pacific region [23, pp. 49-50, and 54, pp. 13-14]. Earlier plans for a gas pipeline from the Sakhalin gas fields in Russia to Japan have been changed to building an LNG export terminal; but even that project seems unlikely until after the end of this century because of economic and political problems in Russia. Also, the continuing tensions between the two countries over Russian occupation of several small Japanese islands that have continued since World War II continues to discourage Japanese investments in Russia 123, pp. 49$50 ; 36$, p. 52; and 20, p. 8].

Overall consumption of natural gas in Japan is projected to grow at a rate comparable to that of Europe, so that Japanese demand for this fuel should almost double between 1990 and 2010 to $3.5 \mathrm{Tcf}$ in 2010 . Demand in China could triple between 1990 and 2010 to $1.3 \mathrm{Tcf}$ by 2010 . Japan will use this relatively cleanburning fuel to support economic growth and to diversify energy supplies. China will use gas to support what is expected to be the fastest growing economy in the world. 


\section{Abundant reserves and low cost keep coal a major energy source; but technology, environmental concerns, and subsidy phaseouts modify trade.}

Coal, an economical energy resource that has been used intensively all over the world in the past, continues to face a strong future. Between 1990 and 2010 it ranks second among all energy sources, although its share of iotal energy consumption declines slightly-from about 27 to 25 percent. The amount of coal consumed will likely expand by 32 percent during the projection period (from 5,001 million short tons in 1992 to 6,606 million short tons in 2010), mostly due to economic considerations (Table A5 and Figure 27). Increased coal use in China alone is expected to account for about three-fifths of this projected increase.

Figure 27. Total World Coal Consumption, 1980-2010

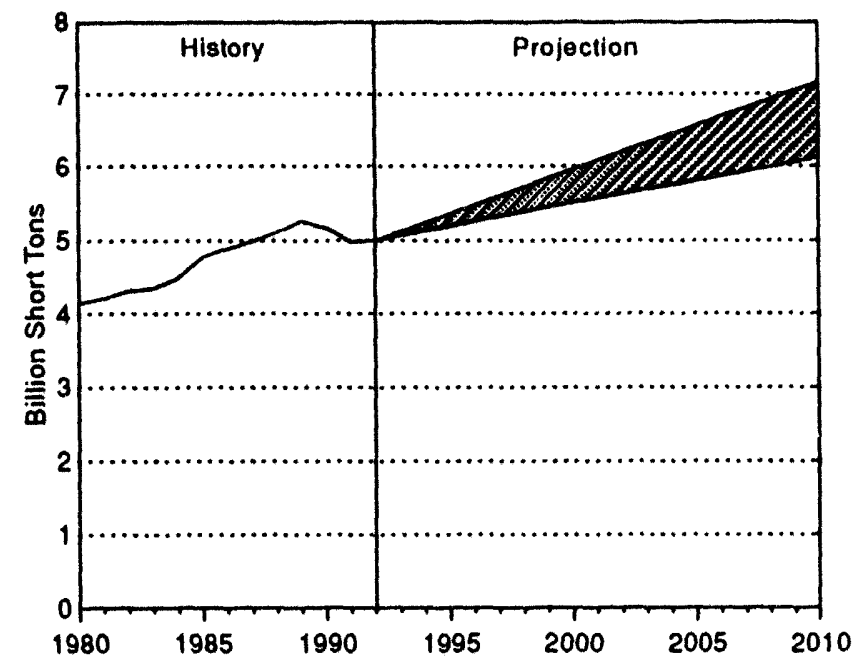

Sources: History: Energy Information Administration, International Energy Annual 1992, DOE/EIA-0219(92), Table 10 and related data base. Projections: Table A5.

Coal resources are abundant in many parts of the world. However, combustion of this fuel produces a high proportion of the greenhouse gas, carbon dioxide; and-absent the use of appropriate pollution control equipment-the use of coal also contributes a range of emissions that affect ground-level air quality adversely. Environmental standards notwithstanding, though, coa! will be a major energy source for baseload electric power generation in the future-particularly as oil and gas prices rise and "clean coal technology" advances. Burning coal in order to generate electricity will account for most of the coal consumption worldwide.

Historical trading patterns for coal are likely to be skewed by several developments. In some countries, for example, the cost of mining coal has become uneconomical; and many governments are trying to restructure their energy industries while minimizing harm to their economies as a whole. Coal production worldwide will also be affected by new emphasis on cleaner coals, as well as by increased efficiencies and other technological advances. Environmental considerations will probably be the most restraining factor in the future use of coal, however; so this explains the special significance of the projected introduction of clean coal technologies-which should make the burning of coal to produce electricity more efficient while at the same time greatly reducing the sulfur and nitrogen oxides pollutants emitted into the atmosphere in the process.

Coal consumption is expected to grow most rapidly in the Eurasia country group (Figure 28), with China leading the way. Eurasia could account for fully half of total world coal consumption by 2010, compared to about 47 percent in 1990 (Figure 29). Assuming no change in environmental policies in China, coal should continue to provide close to three-quarters of all energy consumed there between now and 2010 (Figure 30). The surge in the volume of coal use would come primarily from projected expansion of the Chinese economy (Table 1 on page 7).

China has the third largest coal reserves in the world (Figure 31), and its domestic consumption of coal is projected to almost double between 1990 and 2010 . China was the first country ever to produce more than 1 billion short tons of coal in a single year, and it continues record-breaking annual production [11, p. 12]. China currently leads the world with its rate of economic growth and it should hold this position throughout the next decade as its vast modernization continues. Coal is expected to be the primary energy source for 
new electricity power plants being built to promote industrialization and raise living standards. Even if clean coal technologies are adopted, however, there will undoubtedly be global concerns about environmental impacts. The United States is currently planning strategies to help China with implementation of clean coal technologies.

Figure 28. World Coal Consumption by Major Country Groupings, 1980-2010

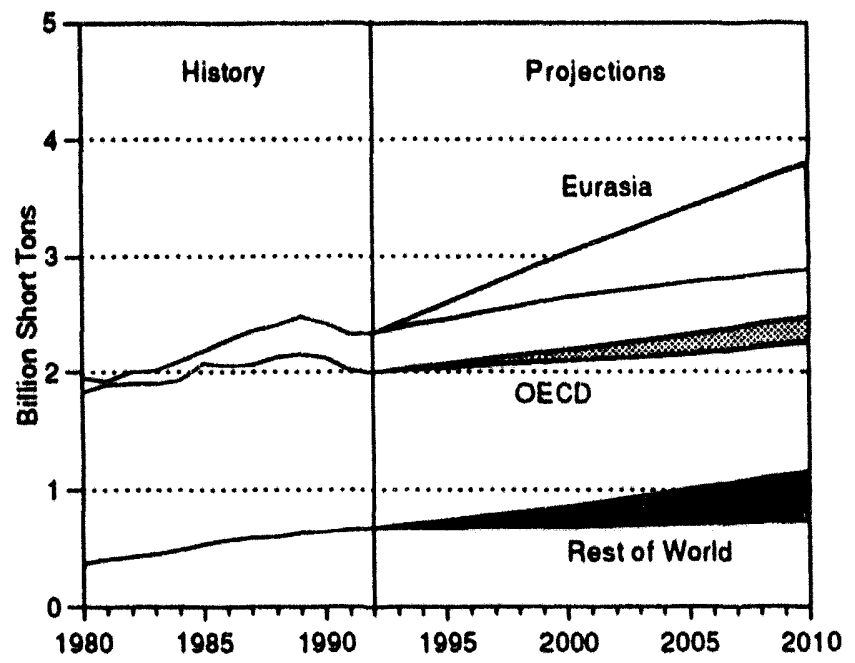

Sources: Hibtory: Energy Information Administration, International Energy Annual 1992, DOE/EIA.0219(82), Table 10 and related data base. Projectione: Table A5.

Figure 29. Share of Coal Consumption by Major Country Groupings, 1980-2010

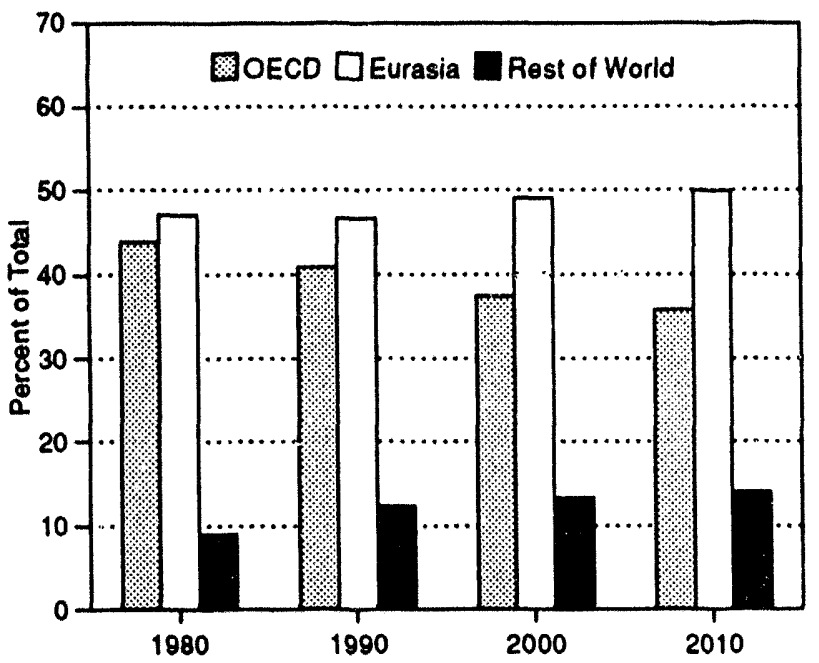

Sources: Hietory: Energy Information Administration, International Energy Annual 1992, DOE/EIA-0219(92). Table 10 and related data base. Projections: Table A5.
Figure 30. Coal Consumption as a Percentage of Total Energy Consumption, 1980-2010

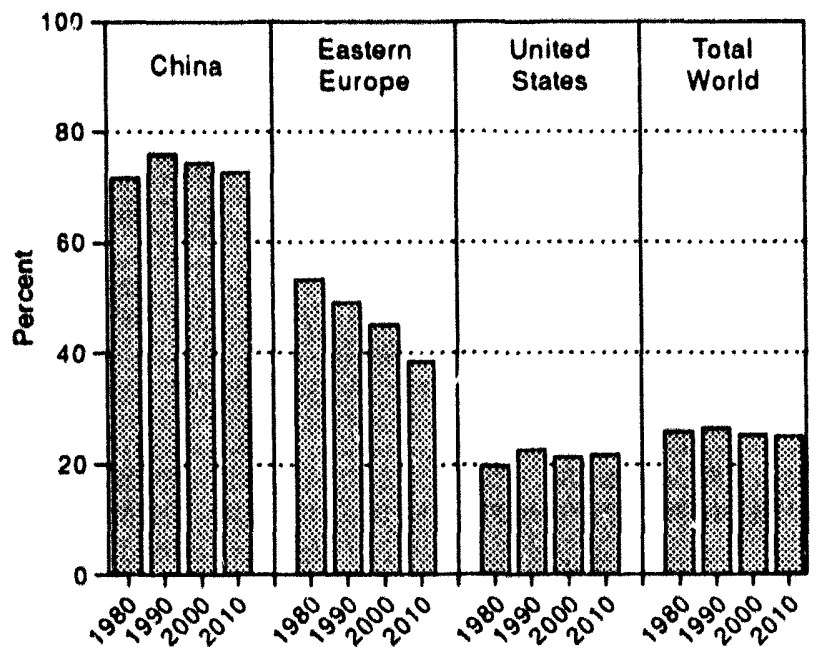

Sources: Hislory: Energy Information Administration (E|A), International Energy Annual 1992, DOE/EIA.0219(92), Tables A9 and A12 and related data base. Projectlons: EIA, World Energy Projection System, 1994

\section{Flgure 31. World Coal Reserves}

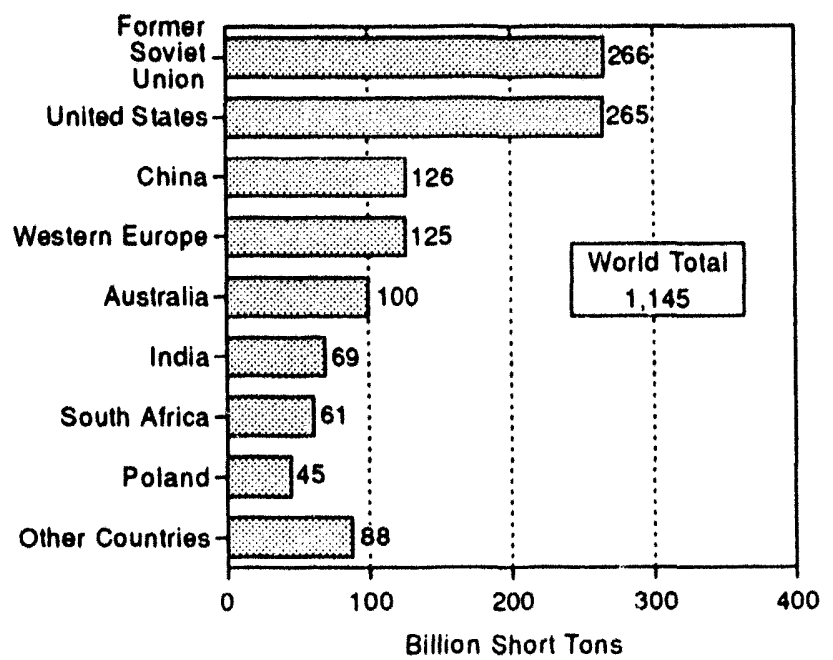

Source: Energy Information Administration, International Energy Annual 1992, DOE/ElA.0219(92), Table 37.

Most other Asian countries have limited domestic energy resources and must import nearly all the coal they need to meet strong projected demand growth. Japan, for instance, produced 9 million tons of coal itself in 1990 but consumed 125 million tons [11, pp. 12, 28]. Although its economic growth has slowed relative to previous years, Japan is still projected to grow faster than any other member of the Organization for Economic Cooperation and Development (OECD), and its 
demand for coal imports over the projection horizon is the largest of any country.

Exceptional economic growth in the newly industrialized countries, such as South Korea and Taiwan, has also helped to give Asia the largest share of projected coal import demand. The Pacific Rim countries in general are planning to add substantial amounts of coal-fired generating capacity. In Asia overall, coal imports are projected to rise during the two decades from 184 million tons in 1990 to 385 million tons in 2010, or about 201 million tons (Table 8).

Table 8. World Coal Flows by Importing and Exporting Reglons, Base Case (Million Short Tons)

\begin{tabular}{|c|c|c|c|c|c|c|c|c|c|c|c|c|}
\hline \multirow[b]{3}{*}{ Exportore } & \multicolumn{12}{|c|}{ Importors } \\
\hline & \multicolumn{4}{|c|}{ Stoam } & \multicolumn{4}{|c|}{ Motallurgical } & \multicolumn{4}{|c|}{ Total } \\
\hline & Europe & Asia & Othor & Total & Europo & Asia & Other & Total & Europe & Asla & Other & Total \\
\hline & \multicolumn{12}{|c|}{1990} \\
\hline Australia $\ldots \ldots \ldots \ldots$ & 11 & 41 & 0 & 54 & 14 & 48 & 2 & 63 & 24 & 89 & 2 & 117 \\
\hline United Statos . . . . . . . & 24 & 6 & 11 & 42 & 35 & 14 & 12 & 63 & 59 & 21 & 23 & 106 \\
\hline South Arrica . . . . . . . & 31 & 18 & 1 & so & 0 & 4 & 0 & 4 & 32 & 22 & 1 & 54 \\
\hline Former Soviot Union . . . & 14 & 3 & 0 & 18 & 13 & 6 & 0 & 25 & 27 & 9 & 0 & 43 \\
\hline Poland ........... & 23 & 0 & 0 & 19 & 4 & 0 & 3 & 12 & 27 & 0 & 3 & 31 \\
\hline Canada $\ldots \ldots \ldots \ldots$ & 1 & 3 & 1 & 5 & 3 & 26 & 2 & 30 & 4 & 28 & 3 & 34 \\
\hline China $\ldots \ldots \ldots \ldots \ldots$ & 3 & 8 & 0 & 17 & 0 & 1 & 0 & 2 & 3 & 9 & 0 & 19 \\
\hline South America . ...... & 11 & 1 & 2 & 16 & 0 & 0 & 0 & 1 & 11 & 1 & 2 & 17 \\
\hline Other $\ldots \ldots \ldots \ldots$ & 11 & 5 & 0 & 14 & 5 & 0 & 0 & 6 & 16 & 5 & 0 & 20 \\
\hline \multirow[t]{2}{*}{ Total $\ldots \ldots \ldots \ldots$} & 130 & 84 & 15 & 236 & 74 & 100 & 18 & 205 & 204 & 184 & 33 & 441 \\
\hline & \multicolumn{12}{|c|}{2000} \\
\hline Australia .... . & 0 & 94 & 0 & 84 & 11 & 51 & 0 & 63 & 11 & 145 & 0 & 156 \\
\hline United States. & 51 & 11 & 9 & 71 & 26 & 23 & 13 & 62 & 76 & 35 & 22 & 133 \\
\hline South Africa . . . . . & 66 & 0 & 2 & 68 & 0 & 5 & 0 & 5 & 66 & 5 & 2 & 73 \\
\hline Former Soviet Union . . . & 8 & 4 & 2 & 15 & 3 & 1 & 3 & 7 & 12 & 6 & 5 & 22 \\
\hline Poland $\ldots \ldots \ldots \ldots$ & 8 & 0 & 1 & 8 & 8 & 0 & 0 & 8 & 16 & 0 & 1 & 17 \\
\hline Canada ........... & 5 & 4 & 1 & 10 & 6 & 16 & 1 & 22 & 10 & 20 & 2 & 32 \\
\hline China ............ & 3 & 18 & 1 & 23 & 0 & 2 & 2 & 4 & 3 & 20 & 4 & 27 \\
\hline South America ....... & 4 & 40 & 8 & 52 & 0 & 0 & 0 & 0 & 4 & 40 & 8 & 52 \\
\hline Other $\ldots \ldots \ldots \ldots$ & 12 & 24 & 4 & 40 & 0 & 0 & 0 & 0 & 12 & 24 & 4 & 40 \\
\hline \multirow[t]{2}{*}{ Total } & 157 & 196 & 29 & 381 & 54 & 88 & 19 & 171 & 211 & 294 & 48 & 553 \\
\hline & \multicolumn{12}{|c|}{2010} \\
\hline Australia ............ & 21 & 124 & 0 & 144 & 10 & 51 & 0 & $\overline{61}$ & 31 & 174 & 0 & 205 \\
\hline United States . . . . . . & 62 & 27 & 9 & 97 & 25 & 18 & 12 & 55 & 87 & 44 & 21 & 152 \\
\hline South Africa . . . . . . . . & 65 & 22 & 2 & 89 & 0 & 5 & 0 & 5 & 65 & 27 & 2 & 84 \\
\hline Former Soviet Union . . . & 9 & 4 & 4 & 17 & 3 & 1 & 3 & 7 & 12 & 5 & 7 & 23 \\
\hline Poland $\ldots \ldots \ldots \ldots$ & 7 & 0 & 2 & 9 & 12 & 0 & 0 & 12 & 18 & 0 & 3 & 21 \\
\hline Canada . . . . . . . . . & 0 & 9 & 1 & 10 & 4 & 14 & 1 & 18 & 4 & 23 & 2 & 28 \\
\hline China $\ldots \ldots \ldots \ldots$ & 5 & 22 & 2 & 29 & 0 & 2 & 2 & 4 & 5 & 24 & 4 & 33 \\
\hline South Amorica ....... & 19 & 60 & 10 & 89 & 0 & 0 & 0 & 0 & 19 & 60 & 10 & 89 \\
\hline Other $\ldots \ldots \ldots \ldots$ & 22 & 27 & 5 & 54 & 0 & 0 & 0 & 0 & 22 & 27 & 5 & 54 \\
\hline Total . . . . . . . . . & 208 & 285 & 36 & 538 & 54 & 90 & 18 & 162 & 262 & 385 & 53 & 700 \\
\hline
\end{tabular}

Includes principally Indonesia's trade within Asia, as well as the United Kingdom and Germany's trade within Europe.

Note: Totals may not equal sum of components due to independent rounding. The sum of the columns may not equal the total, because the total includes a balancing them between importers' and exporters' data. In the case of China and the former Soviet Union, the balancing item for 1990 amounted to between 5 and 7 million short tons.

Sources: History-Energy Information Administration (EIA), Otfice of Integrated Analysis and Forecasting estimates. Projectiono-EIA, Coal Export Model, 1994. 
With the Pacific Rim countries seen as the fastest growing market for coal over the projection period, supplying countries in that part of the world should benefit as well. For example, Australia's exports should nearly double by 2010. Australian domestic consumption could climb slightly, but nearly half of its total production should remain dedicated to the export market. Australia should export about 30 percent more to Japan in 2010, but its market share falls slightly as Japan works on diversifying its suppliers and Australia expands into other Asian markets. Australia is expected to capture nearly 45 percent of the total flourishing Asian coal market by 2010 . Meanwhile, U.S. producers are projected to only maintain their market share throughout the projection period, striving to double U.S. coal exports to Asia.

Usually the most expensive on the international coal market, the United States should nevertheless hold on as the world's second largest exporter-but with its share of the market declining by about 2 percent over the projection period. Asian coal markets are expected to dominate over the projection period, and U.S. exporters will find it more difficult to compete with the coalproducing countries near Asia, notably Australia, China, and Indonesia. Total U.S. exports of coal are projected to grow from 106 million tons in 1990 to 152 million tons in 2010. Conversely, passage of the Clean Air Act Amendments of 1990 in the United States-a catalyst for other countries to take more actions for environmental protection-may also be the catalyst for more coal imports by this country. Competitive foreign suppliers are offering low-sulfur coal to some U.S. customers-especially in coastal regions-at cheaper prices than can be found on the domestic market. Imports into the United States are seen growing to 11 million tons over the projection period [8, p. 72].

Since most Western European countries are pushing to reduce coal production subsidies and eliminate unprofitable mines, European imports seem destined to rise, even with strong support for new and more stringent anti-pollution regulations. Steam coal imports are projected to grow by 78 million tons-from 130 million tons in 1990 to 208 million tons in 2010. Meanwhile, environmental concerns in Western Europe will play an important role in the competition among coal, natural gas, and nuclear power.

In Eastern Europe the rivalry among energy sources will more likely be on economic grounds, with most countries there heing compelled to take economic considerations into account more than before. Antiquated and currently uneconomical coal-mining operations will find little new capital available to update themthus forcing each country to produce only as much coal as it really needs for domestic consumption, despite desires to earn much-needed foreign currency through exports. Political and economic turmoil in Poland and Russia further inhibit export projections, which dropped sharply after 1990. By 2010, Poland and Russia are projected to regain only about half of their pre-1990 export levels. Despite all these elements, however, the fact that coal is virtually the only indigenous energy resource in most of Eastern Europe will tend to siow the decline of its use there.

Technological changes and continued slow growth anticipated for the steel industry point to a tapering off of the demand for metallurgical coal, which before the 1980 's was more important in international trade than steam coal-the type used in electricity generation (Figure 32). Total trade in metallurgical coal is projected to decline by 43 million tons over the 20 -year projection period-to 162 million tons in 2010. This trend masks individual country trends, but in global terms steam coal consumption is expected to eclipse metallurgical consumption in the future.

Figure 32. World Coal Trade, 1980-2010

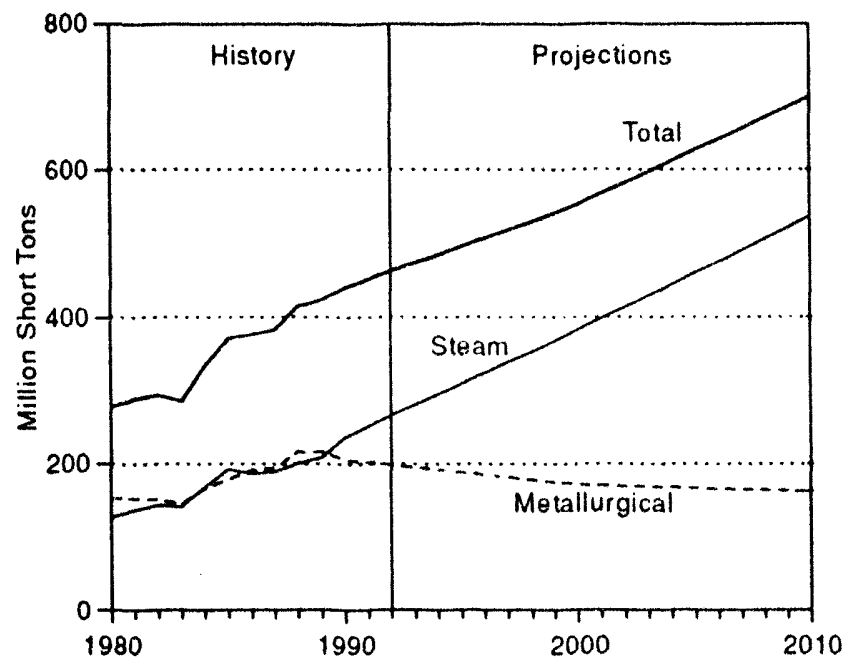

Sources: History: Energy Information Administration (EIA), Annual Prospects for World Coal Trade 1991, DOE/EIA-0363(91), pp. 2-3. Projections: EIA, Coal Export Model 1994, National Energy Modeling System. 


\title{
Nuclear Power
}

\author{
Global warming concerns, economics, and public questions of safety are \\ uncertainty factors, but little net change in nuclear capacity is foreseen by 2010.
}

Growth in nuclear power worldwide has slowed, and this trend is expected to continue. Overall nuclear capacity is projected in the Lower Reference Case to be approximately three percent greater in 2010 than it was in 1990. The three countries with the most projected capacity additions are Japan, South Korea and France; while seven countries, the majority in Western Europe, are expected to have less capacity by 2010 than they have now.

Although nuclear plant performance has been stable over the past two years, worldwide efforts to improve nuclear safety and to standardize the advanced reactor designs should improve performance in the future. However, public opinion is still largely negative toward nuclear power in a number of countries, and several challenges face the nuclear industry and its prospects for new orders.

Worldwide, 14 percent of existing reactors have passed the midpoint of their design lives (assuming a $\mathbf{4 0}$ year life), raising concerns about the safety of continued operation [37, p. 6-3]. The problems of long-term disposal for high-level waste and the decommissioning expenses involved when reactors are retired also continue to be major concerns. Although worries about possible global warming have brought some fresh support for nuclear reactors (which-unlike fossil-fuel generating systems-release essentially no carbon dioxide during operation), it is likely that nuclear power will have to demonstrate economic advantages over alternative generation technologies; including the cost of decommissioning and disposal costs, in specific sites, if many new reactors are to be ordered.

Because of the uncertainties remaining in the outlook for this energy source, worldwide nuclear capacity is projected to grow to a total capacity of somewhere between 339 gigawatts and 413 gigawatts by 2010-in a Lower and an Upper Reference Case, respectively (Table 9). The Lower Reference Case reflects a continuation of the present trends in the nuclear power industry, while the Upper Reference Case reflects a moderate revival in nuclear orders.

Future energy policy decisions, including nuclear capacity expansion, could be influenced appreciably by concerns about global climate change. The largest contributor to the proliferation of greenhouse gases is the combustion of fossil fuels for transportation, industrial processes, and electricity generation. Because the nuclear fission process emits no greenhouse gases, reactor systems are a potential substitute for coal-fired generation in many industrial nations that have no other non-greenhouse fuel sources. However, a number of other factors affect the choice of nuclear power. Among them are concerns about safety, the relative economics of operation, financing and nuclear waste disposal. For example, nations such as Sweden, Norway, and the Netherlands question the acceptability of the nuclear option on safety grounds.

As the box in this section summarizes, nuclear power has been used in a number of countries for decades. The accidents at Three Mile Island (TMI) in the United States in 1979, and at Chernobyl in the Ukraine in 1986 inhibited growth in nuclear capacity worldwide. The immediate consequences of TMI were increased public opposition to nuclear power and increased regulatory actions aimed at enhancing safety-which caused a significant short-term decrease in performance and a sharp increase in both the construction and operating costs of nuclear units in the United States.

As a response to TMI, the Institute of Nuclear Power Operations (INPO) was formed in the United States to promote safety and reliability; but the Chernobyl accident brought to world attention the special safety problems of the Soviet-designed East European reactors, and public fears about any type of nuclear unit grew. This led to the creation in 1989 of the World Association of Nuclear Operators (WANO) as a direct response to the concerns raised by the Chernobyl accident. The goal of WANO is to maximize safety and 


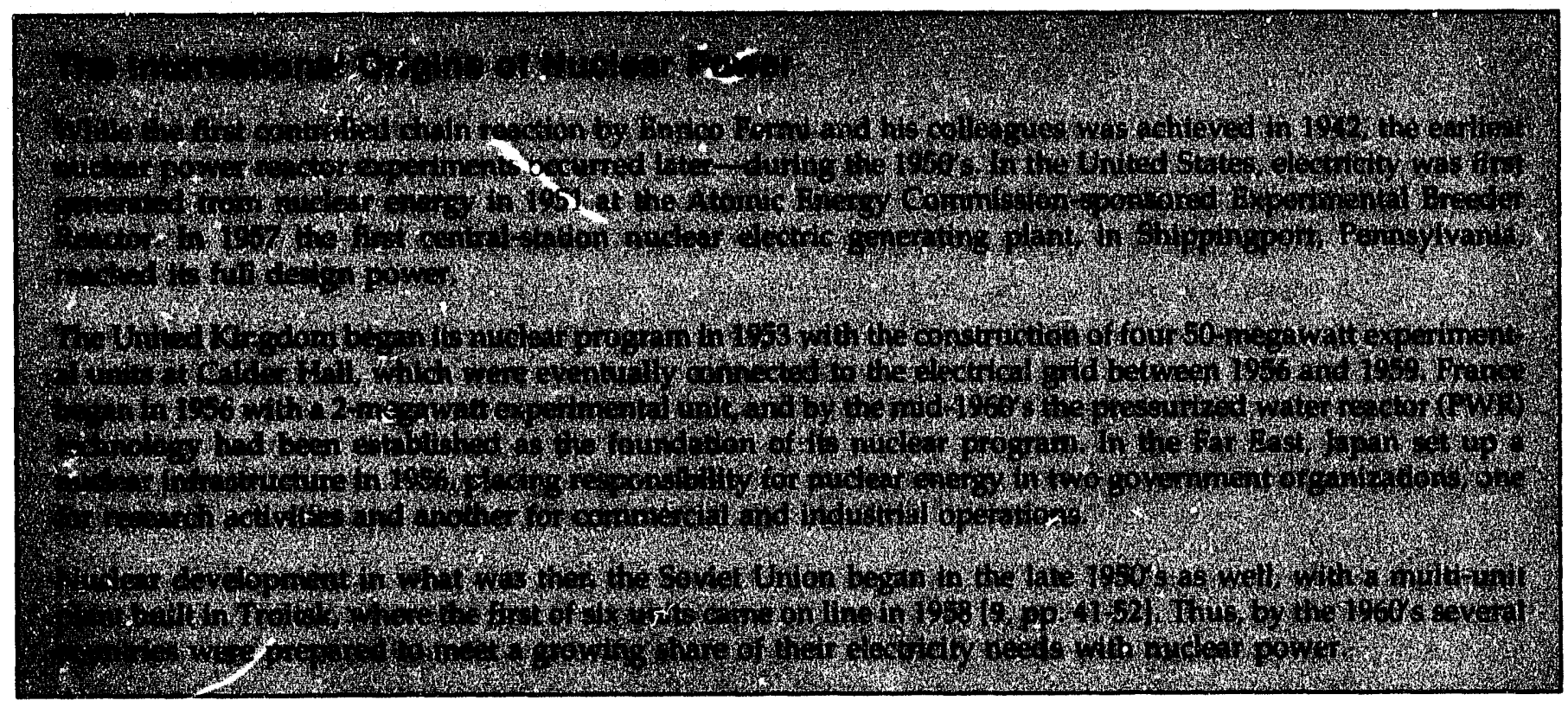

reliability at all nuclear power plants through the exchange of information and increased communication among all its members.

Since the breakup of the former Soviet Union (FSU), more questions have arisen regarding the safety of continued operation of some Soviet-designed nuclear reactors in Eastern Europe. Many of the republics where the nuclear plants are situated need them to meet present electricity demand, but cannot afford the repairs necessary to meet Western safety standards. Additionally, some units suffer poor management and operation because the current operators are not sufficiently familiar with the details of their original manufacture. For example, several units operating in the Ukraine and Bulgaria were built by the Russians, with little or no input from the respective republics, but they no longer receive any Russian assistance in the operation of the plants [51, p. 20].

Electricity supply systems, or parts of them, are publicly owned in a number of countries, including Argentina, India, South Korea and Mexico; but there has been a trend toward privatization in this field. In 1988, the United Kingdom restructured its electricity supply industry and put its three existing generating boards into the private sector. (For more detail on this privatization move in the United Kingdom, see [9], pp. 23-25.) It quickly became evident that nuclear power in the United Kingdom was unable to compete with fossil-fueled technology in attracting private investment under the new arrangement, so the government announced by the end of the following year that the whole nuclear power sector of the electric utility industry would be withdrawn from the privatization program. Privatization increases incentive to minimize financial risk, implying low capilial costs; it also generates competition, resulting in decisions made on the basis of the least cost, most economically efficient method of electricity generation. As nuclear power plants have been generally characterized by high capital costs and high risk, changes must be made in the nuclear industry to remove financial risk and uncertainty so that it can become economically competitive with other generating technologies. Risk and uncertainty can be reduced by improving operating performance and structuring ownership strategies such that financial risk is allocated among a number of parties.

The optimism of the late 1970's in regard to apparent economic benefits from nuclear power was based on the rapid increases in competing oil and gas prices that were then taking place. However, prices for oil and gas fell sharply during the mid-1980's, and generally lower prices are expected to be maintained. Despite stricter clean-air statutes, the projections of operating costs for coal-fired plants have also declined, bringing them closer to the projected costs for nuclear power. Additionally, some governments and utilities have begun to use higher discount rates in evaluating investment choices (especially for nuclear power, because of its perceived uncertainty and risk). Higher discount rates increase the computed costs for capital-intensive technologies such as nuclear power, as compared with less capital-intensive technologies such as gas-burning combined-cycle plants [38, p. 35]. Nuclear power's chief hope lies in reducing costs by simplifying and standardizing plant designs, and by improving economic and technical performance. 
Table 9. Historical and Projected Operable Nuclear Capacitles (Net Gigawatts)

\begin{tabular}{|c|c|c|c|c|c|c|c|c|c|}
\hline \multirow[b]{2}{*}{ Couniry } & \multirow[b]{2}{*}{$1902^{\circ}$} & \multicolumn{2}{|c|}{1995} & \multicolumn{2}{|c|}{2000} & \multicolumn{2}{|c|}{2005} & \multicolumn{2}{|c|}{2010} \\
\hline & & $\begin{array}{c}\text { Lower } \\
\text { Relerence } \\
\text { Case }\end{array}$ & $\begin{array}{c}\text { Uppor } \\
\text { Roference } \\
\text { Case }\end{array}$ & $\begin{array}{c}\text { Lower } \\
\text { Reforence } \\
\text { Cace }\end{array}$ & $\begin{array}{c}\text { Upper } \\
\text { Roference } \\
\text { Caseo }\end{array}$ & $\begin{array}{c}\text { Lower } \\
\text { Relerence } \\
\text { Case }\end{array}$ & $\begin{array}{c}\text { Upper } \\
\text { Reference } \\
\text { Case }\end{array}$ & $\begin{array}{c}\text { Lower } \\
\text { Reforence } \\
\text { Case }\end{array}$ & $\begin{array}{c}\text { Upper } \\
\text { Reference } \\
\text { Case }\end{array}$ \\
\hline \multicolumn{10}{|l|}{ OECD } \\
\hline United States . . . . . & 99.0 & 100.3 & 100.3 & 102.6 & 102.6 & 103.8 & 103.8 & 90.7 & 90.7 \\
\hline Canada .......... & 14.6 & 15.4 & 15.4 & 15.4 & 15.4 & 15.4 & 19.1 & 15.4 & 22.9 \\
\hline $\begin{array}{l}\text { Japan } \ldots . . . . . . \\
\text { Weatern Europe }\end{array}$ & 34.2 & 35.1 & 41.1 & 41.1 & 43.7 & 43.7 & 47.6 & 45.7 & 56.7 \\
\hline Bolgium ......... & 5.5 & 5.5 & 5.5 & 5.5 & 5.5 & 3.8 & 5.5 & 3.8 & 5.5 \\
\hline Finland $\ldots \ldots \ldots$ & 2.3 & 2.3 & 2.3 & 2.3 & 2.3 & 2.3 & 2.8 & 2.3 & 3.3 \\
\hline Franco $\ldots \ldots \ldots$ & 57.7 & 58.5 & 58.5 & 61.4 & 61.4 & 61.4 & 62.8 & 62.1 & 69.8 \\
\hline Germany ........ & 22.5 & 22.5 & 22.5 & 22.5 & 22.5 & 22.5 & 22.5 & 22.5 & 24.7 \\
\hline Italy .......... & 0.0 & 0.0 & 0.0 & 0.0 & 0.0 & 0.0 & 0.0 & 0.0 & 1.2 \\
\hline Netherlands ..... & 0.5 & 0.5 & 0.5 & 0.5 & 0.5 & 0.0 & 0.6 & 0.0 & 1.2 \\
\hline Spain ........... & 7.1 & 7.1 & 7.1 & 7.1 & 7.1 & 7.1 & 7.1 & 7.1 & 9.1 \\
\hline Sweden ......... & 10.0 & 10.0 & 10.0 & 10.0 & 10.0 & 6.7 & 6.7 & 0.0 & 6.7 \\
\hline Switzerland ...... & 2.9 & 2.9 & 2.9 & 2.9 & 2.9 & 2.9 & 2.9 & 2.9 & 3.6 \\
\hline United Kingdom . . . & 11.9 & 11.7 & 11.7 & 10.4 & 11.6 & 9.9 & 9.9 & 6.1 & 8.0 \\
\hline Total OECD . . . . . . & 268.3 & 271.8 & 277.8 & 281.6 & 285.5 & 279.5 & 291.2 & 258.7 & 303.4 \\
\hline \multicolumn{10}{|l|}{ Eurasia } \\
\hline $\begin{array}{l}\text { China ............ } \\
\text { Eastern Europe }\end{array}$ & 0.3 & 1.2 & 1.2 & 2.1 & 2.1 & 2.7 & 2.7 & 2.7 & 4.2 \\
\hline Bulgaria . . . . . . . . & 3.5 & 3.5 & 3.5 & 2.7 & 3.5 & 2.3 & 3.5 & 1.9 & 3.7 \\
\hline Czech Republic ... & 1.6 & 1.6 & 2.5 & 2.5 & 3.4 & 3.4 & 3.4 & 3.4 & 3.4 \\
\hline Slovak Ropublic ... & 1.6 & 1.2 & 1.2 & 1.2 & 1.2 & 1.2 & 1.6 & 1.6 & 2.4 \\
\hline Hungary ......... & 1.7 & 1.7 & 1.7 & 1.7 & 1.7 & 1.7 & 2.9 & 1.7 & 2.9 \\
\hline Romania $\ldots \ldots \ldots$ & 0.0 & 0.0 & 0.6 & 1.2 & 1.2 & 1.2 & 1.9 & 1.2 & 2.5 \\
\hline Slovenia $\ldots . . \ldots$ & 0.6 & 0.6 & 0.6 & 0.6 & 0.6 & 0.6 & 0.6 & 0.6 & 0.6 \\
\hline \multicolumn{10}{|l|}{ Former Soviei Union } \\
\hline Russia . . . . . . . & 17.8 & 17.8 & 17.8 & 17.9 & 20.6 & 17.1 & 22.8 & 18.9 & 25.3 \\
\hline Ukraine ........ & 13.0 & 10.2 & 10.2 & 12.1 & 12.1 & 13.1 & 14.0 & 12.7 & 15.0 \\
\hline Armenia . . . . . . . . & 0.0 & 0.4 & 0.4 & 0.8 & 0.8 & 0.8 & 1.4 & 0.6 & 1.2 \\
\hline Kazakhstan ..... & 0.1 & 0.1 & 0.1 & 0.1 & 0.1 & 0.1 & 1.1 & 0.1 & 2.1 \\
\hline Lithuania . . . . . . & 2.5 & 2.5 & 2.5 & 2.5 & 2.5 & 2.5 & 3.5 & 2.5 & 3.5 \\
\hline Total Eurasia ..... & 42.8 & 40.9 & 42.4 & 45.6 & 49.9 & 46.8 & 59.5 & 48.1 & 66.8 \\
\hline \multicolumn{10}{|l|}{$\begin{array}{l}\text { Rest of World (ROW) } \\
\text { Far East }\end{array}$} \\
\hline Korea, South ..... & 7.2 & 7.2 & 7.2 & 7.2 & 9.8 & 11.7 & 12.9 & 12.9 & 16.4 \\
\hline Korea, North ..... & 0.0 & 0.0 & 0.0 & 0.1 & 0.1 & 0.1 & 0.3 & 0.1 & 0.9 \\
\hline Philippines ...... & 0.0 & 0.0 & 0.6 & 0.6 & 0.6 & 0.6 & 0.6 & 0.6 & 0.6 \\
\hline Taiwan $\ldots . \ldots$. & 4.9 & 4.9 & 4.9 & 4.9 & 5.8 & 5.8 & 6.8 & 6.8 & 7.8 \\
\hline \multicolumn{10}{|l|}{ Other } \\
\hline Argentina . . . . . . & 0.9 & 0.9 & 1.6 & 1.6 & 1.6 & 1.3 & 1.9 & 1.3 & 2.1 \\
\hline Brazil .......... & 0.6 & 0.6 & 0.6 & 1.9 & 1.9 & 1.9 & 3.1 & 3.1 & 3.9 \\
\hline Cuba ........... & 0.0 & 0.0 & 0.0 & 0.0 & 0.4 & 0.4 & 0.8 & 0.4 & 0.8 \\
\hline India .......... & 1.8 & 2.1 & 2.3 & 2.9 & 2.9 & 2.6 & 4.1 & 3.8 & 4.6 \\
\hline Mexico .......... & 0.7 & 0.7 & 1.3 & 1.3 & 1.3 & 1.3 & 1.3 & 1.3 & 1.9 \\
\hline Pakistan ....... & 0.1 & 0.1 & 0.1 & 0.1 & 0.1 & 0.0 & 0.4 & 0.3 & 0.7 \\
\hline South Africa . . . . . & 1.8 & 1.8 & 1.8 & 1.8 & 1.8 & 1.8 & 1.8 & 1.8 & 2.8 \\
\hline Total ROW ...... & 18.1 & 18.3 & 20.5 & 22.5 & 26.4 & 27.5 & 34.1 & 32.4 & 42.5 \\
\hline Total World ......... & 329.2 & 331.0 & 340.7 & 349.7 & 361.8 & 353.8 & 384.8 & 339.2 & 412.7 \\
\hline
\end{tabular}

'Status as of December 31, 1992.

OECD = Organization for Economic Cooperation and Development.

Notes: Totals may not equal sum of components due to independent rounding. The Lower and Upper Reference Cases reflect varying degrees of optimism regarding nuclear power.

Sources: United States-Energy Information Administration, Annual Energy Outlook 1994, DOE/ElA-0383(94). Foreign-Energy Information Administration, World Nuclear Capacity and Fuel Cycle Requirements 1993, DOE/EIA-0436(93). 


\section{Recent Status}

Nuclear-generated electricity increased slightly in 1992, with the production of 2,023 net terawatthours worldwide. The United States, France, Germany, FSU, and Japan accounted for more than 70 percent of this generation. By the end of that year there were 420 operable units in 30 countries, with total net capacity of 329 gigawatts [13, pp. 20-21].

Western Europe relies heavily on nuclear power to satisfy its electricity demands. By the end of 1992 Western Europe generated 41 percent of its electricity with nuclear power, with France and Belgium supplying 73 and 59 percent, respectively, of their country's demand via nuclear power. The nuclear share in the United States was 20 percent; in Japan it was 28 percent. In Eastern Europe, 16 percent of total electricity was nuclear-generated, with 80 percent of that being produced in the FSU [13, p. 20].

Six new nuclear units had come on line during 1992. France started Penley 2, a 1,330-megawatt pressurized water reactor (PWR). India connected two new units to its grid, Narora 2, a 220-megawatt pressurized heavywater moderated and cooled reactor (PHWR), and Kakrapar 1, also a 220-megawatt PHWR, bringing the total number of operable nuclear units in that country to nine. Japan also connected two new units: Ohi 4, a 1,127-megawatt PWR, and Kashiwazaki Kariwa 3, a 1,067-megawatt boiling water reactor (BWR). In Canada, Darlington 3, a 881-megawatt PHWR was connected to the grid [13, p. 19].

Three units were retired during 1992, two of them in the United States. Yankee Rowe, a 167-megawatt PWR that was the oldest operating unit in this country, was retired after 32 years of operation, when tests showed that significant repairs would be needed to continue operation. The utility decided these repairs were too expensive to undertake and instead shut down the plant. San Onofre 1, a 436-megawatt PWR in California, was also retired-because of poor prospective longterm economics. In France, Saint Laurent A2, was retired after operating for 21 years, leaving only one of the original gas-cooled reactors still operating.

In all, 102 units are still in the construction pipelinethat is, either under construction or planned-worldwide, although more than half are less than 25 percent complete. By far the most aggressive expansion program is in Japan, where 23 units totaling 24 gigawatts are in various stages of completion. South Korea has 7 new nuclear units under construction or on order. In Western Europe only France has any significant plans for adding nuclear capacity, with 9 units now being built. Spain has a moratorium on new nuclear capacity, so there is no current schedule to complete the 5 units in its construction pipeline. Similarly, in the FSU, construction has been postponed indefinitely on 13 of 18 new units that are still supposed to be built. Safety concerns at the plants operating in the FSU have combined with major financing problems and an increasing focus on the development of indigenous natural gas resources to make new nuclear capacity an unlikely option there. Among other countries, India has substantial plans for long-term growth in nuclear generating capability - with 8 small units in the construction pipeline, totaling 2.3 gigawatts [13, p. 23].

Several changes occurred during 1993. In the United States, the Trojan unit was retired in early 1993, and Comanche Peak 2 received its full-power license in April. In Canada, Darlington unit 4 became commercially operable in June. In France, Golfech 2 became operable. Japan had four new units connected to the grid during 1993: Genkai 3, Hamaoke 4, Shika 1, and Kashiwazaki Kariwa 4. The two Trawsfynydd units in the United Kingdom, which had been offline since 1991, were officially retired. In China, Guangdong 1 became operable. Finally, in Russia, Balakovo 4 first generated electricity March 23, and became commercially operable in April.

\section{Nuclear Plant Lifetimes and Performance}

Nuclear plant lifetimes are considered formally to be between 30 and 40 years, based on plant designs or the length of the licenses issued; but reactors are not currently achieving such terms. In the United States, the commercial reactors that have been retired have average operating lifetimes of less than 20 years each [44, p. 90]. No U.S. nuclear plant license has yet been extended, although this possibility exists under present regulations. Plants have been shut down before initial license expiration for a number of reasons: physical deterioration of the reactor, physical and political factors that would make continued operation uneconomical, and simply public opposition to nuclear units as potentially unsafe. In France, where nuclear power is supported more widely, and where plants are standardized, reactors are expected to be operable for up to 50 years. Japan's history of nuclear reactor operation has also been good, but the industry there has always taken a conservative approach to decisionmaking. Japan licenses its reactors for 40 years, and several Japanese utilities have announced they have no intention of operating their plants beyond the license expiration dates [37, pp. 4-13].

Nuclear operating performance is measured conventionally by "average capacity factor"-a percentage 
comparison of total actual generation with the amount of electricity that would be produced if a plant operated continuously at full capacity. By this criterion, nuclear performance everywhere outside Eastern Europe has remained stable for the past 2 years. Countries in Western Europe traditionally have very good performance, with Belgium, Finland, the Netherlands, Spain, and Switzerland all reaching capacity factors above $\mathbf{8 0}$ percent for 1992. It should be noted that these countries have relatively small amounts of nuclear generating capacity. France and Japan, the countries with the second and third largest amounts of nuclear capacity in the world, achieved 63-percent and 72-percent capacity factors, respectively. In 1992 the United States improved its operating performance slightly over 1991, with a record capacity factor of $\mathbf{7 1}$ percent. This was the third consecutive year in which a record level was attained in this country [13, p. 72].

\section{Globalization of Industry}

There is current interest in globalizing the nuclear industry - through international mergers of nuclear vendors, design standardization, and the development of consistent safety and regulatory standards. This effort is motivated largely by the shrinking of markets for new nuclear construction.

In the United States, the Electric Power Research Institute (EPRI) is completing a U.S. utility requirements document to determine what utilities and regulators will require of future reactors in this country. The document's goal is to facilitate standardization of reactor designs and lower costs. The EPRI program involves many foreign utility participants who are developing a parallel European Utility Requirements (EUR) Program.

Complementing the EPRI effort is the Advanced Light Water Reactor (ALWR) Program, a joint initiative of the U.S. Department of Energy and the nuclear industry. Its goal is to make standardized ALWRs available for commercial order. The advanced reactors are being developed in two categories-evolutionary and midsized designs. The evolutionary designs, which are large (about 1,300 megawatts each), are improved versions of the light water reactor plants currently in operation. The midsized designs, about 600 megawatts each, incorporate passive safety features (that is, their safety systems are based on the physical and chemical properties of the reactor system itself, thus requiring no mechanical or human intervention to maintain safe operation). Two evolutionary and two midsized plant designs are scheduled to receive Final Design Approval after comprehensive technical and safety reviews by the
U.S. Nuclear Regulatory Commission (NRC) in 1994 and 1996, respectively. In addition, total-plant designs (including non-nuclear portions) are to be standardized. This process will streamline the licensing procedure for new orders by requiring NRC review but not a fullscale reapproval process.

Western Europe has several ongoing efforts to encourage the standardization of nuclear designs, as well as the related operational and regulatory systems, throughout the continent [39]. Nuclear Power International (NPI) is a joint venture of the principal French and German vendors to design and build the next generation of light water reactors. European nuclear regulators are attempting to develop a consensus on common regulatory standards which are similar to the EPRI effort. Economic factors motivated the creation of $\mathrm{NPI}$ as a means to spread the risk in an industry with high capital costs. Additionally, its formation may reduce political controversy over nuclear power by eliminating current competition among different European designs.

The European Utility Requirements program is standardizing safety codes and regulations within a cooperative European regulatory structure. This effort will promote safety and eliminate unnecessary differences in requirements among many countries. The hope is that once uniform, widely accepted Western European standards are in place, the FSU and East European countries will meet the same standards. This will become critical if they intend to trade with or join the European Economic Community.

\section{Projections}

Worldwide nuclear capacity for year-end 1992 and projections through 2010 are shown in Table 9 and Figure 33. Two scenarios are depicted, which reflect varying degrees of optimism about nuclear power-a Lower Reference Case and an Upper Reference Case. Focusing only on projections in the Lower Reference Case (the reader may refer to the Upper Reference Case in Table 9 to obtain a range of projections), growth is expected in half of the countries with nuclear power programs. New nuclear programs are projected to start or to be reinstated in Armenia, Romania, North Korea, the Philippines, and Cuba. In the United States, nuclear capacity is projected to increase by about 5 percent through 2005 (as units under construction are completed), then decrease by about 13 percent because of retirements and the lack of new orders. In Western Europe, France remains the largest player, with a net increase of 4.4 gigawatts by 2010 bringing its total nuclear capacity to 62.1 gigawatts. In the Far East, 
Japan's ambitious plans for nuclear expansion are projected to increase its nuclear capacity by 11.5 gigawatts-to a total of 45.7 gigawatts. South Korea is also expected to increase its nuclear power capability significantly, increasing from 7.2 gigawatts currently to $\mathbf{1 2 . 9}$ gigawatts in 2010. The FSU expects to increase its operable nuclear capacity slightly, from 33.4 gigawatts in 1992 to 34.9 gigawatts in 2010. The majority of the other East European countries plan little or no growth in nuclear capacity due to concerns about safety and difficulties in obtaining financing for nuclear power. Of the countries with smaller programs, Brazil, India and Taiwan have significant growth in nuclear power during the projection period. Brazil's nuclear capacity is expected to grow from only 0.6 gigawatts currently to 3.1 gigawatts in 2010. India is likely to more than double its capability (from 1.8 gigawatts in 1992 to 3.8 gigawatts in 2010), while Taiwan is projected to increase its nuclear capacity by 1.9 gigawatts to reach a total nuclear capacity of 6.8 gigawatts.
Figure 33. Operable and Projected Nuclear Capacity in Varlous Reglons, 1992, 2000, and 2010 (Lower Reference Case)

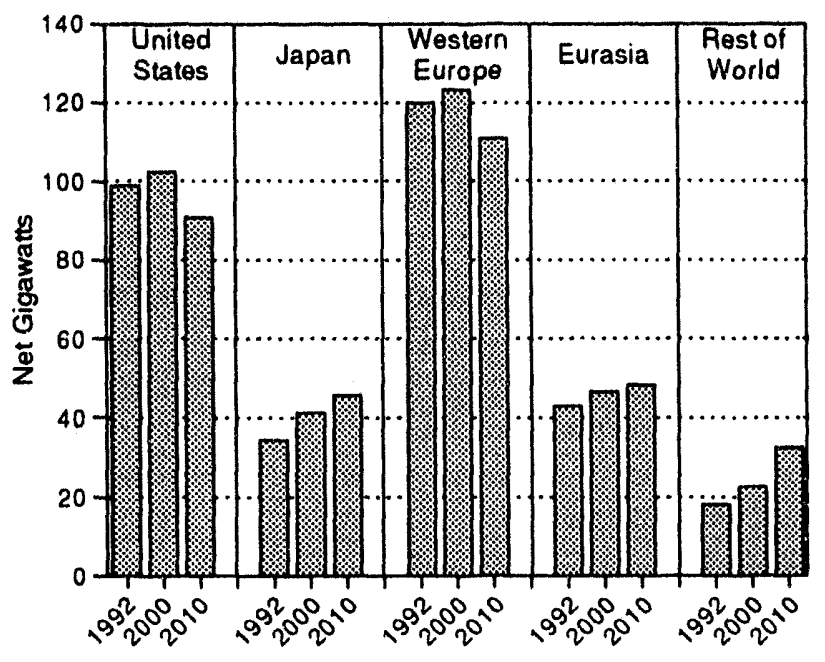

Source: Table 9. 


\title{
Hydroelectric and Other Renewable Energy
}

\author{
Moderate growth is expected, \\ though geography and costs limit potential development.
}

Research continues, especially in the European countries of the Organization for Economic Cooperation and Development (OECD), on renewable energy sources such as geothermal, wind, biomass, and solar power. However, these have been implemented on only a comparatively small scale so far, and-despite a growing number of installations-these sources are not expected to contribute much to the total energy balance on a global basis prior to 2010. In terms of world energy consumption, hydroelectricity also remains a relatively small factor; but is quite important regionally-for example, in Canauda and in the developing countries outside the Organization of Petroleum Exporting Countries (OPEC), including Latin America (Figure 34).

Noncommercial fuels from plant and animal sources are important sources of energy, primarily for household use, in many developing countries. However,

Figure 34. Hydroelectriclty and Other Renewable Energy Consumption as a Percentage of Total Energy Consumption, 1980-2010

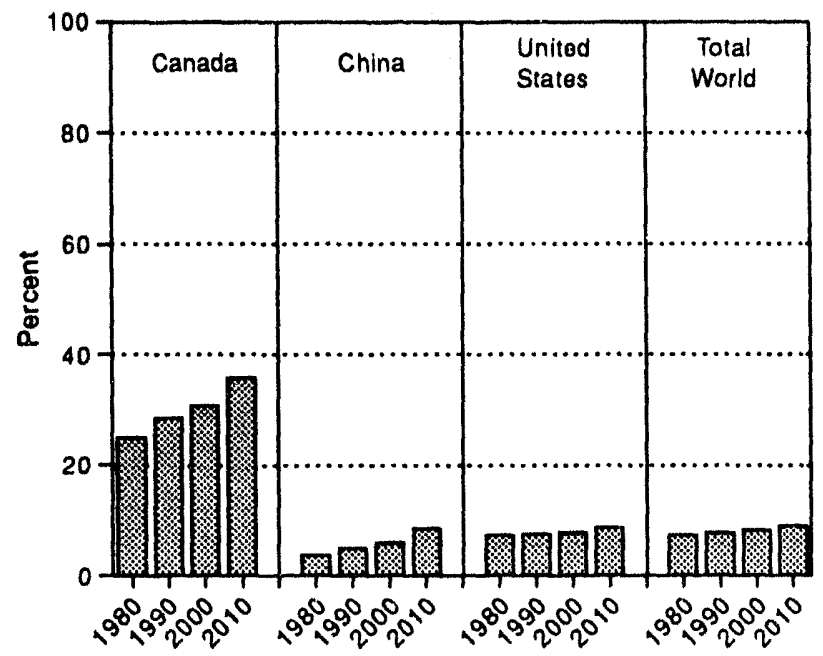

Sources: History: Energy Information Administration (EIA), International Energy Annual 1992, DOE/ElA-0219(92), Tables A9 and $A 13$ and related data base. Projections: EIA, World Energy Projection Systom, 1994. there are no comprehensive data available on the use of these fuels, so they are not incorporated in this report. Further, there are feu. comprehensive international data available on the use of dispersed renewables-renewable energy consumed on the site of its production (such as solar panels for hot water heating)-so these uses of renewable energy are also not reflected in the projections.

Taken as a whole, hydroelectricity and energy used to generate electricity from other renewable sourcesprimarily geothermal, and wind, biomass, and solar power-are expected to grow on average by 2.4 percent per year between 1990 and 2010, with fairly steady increases expected for most regions where they are currently being exploited (Figure 35 and Table A7 in Appendix A. The OECD countries should continue to utilize more than half of the energy derived world wide from these sources (Figure 36); but their use is expected

Figure 35. World Consumption of Hydroelectricity and Other Renewable Energy, 1980-2010

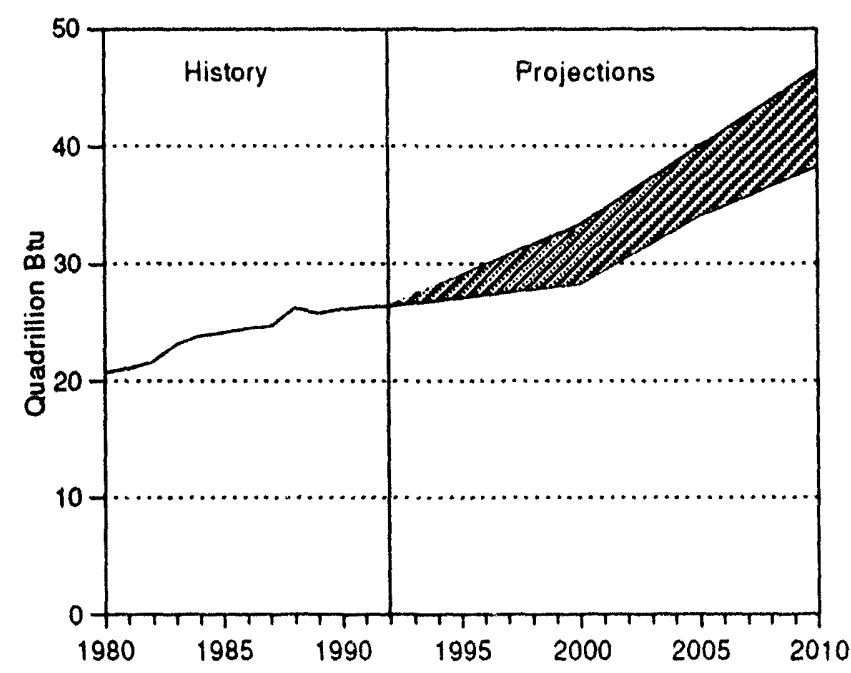

Sources: Hislory: Energy Information Administration, International Energy Annual 1992, DOE/EIA.0219(92), Table A13 and related data base. Projections: Table A7. 
Figure 36. Share of Hydroelectriclty and Other Renewable Energy Consumption by Major Country Groupings, 1980-2010

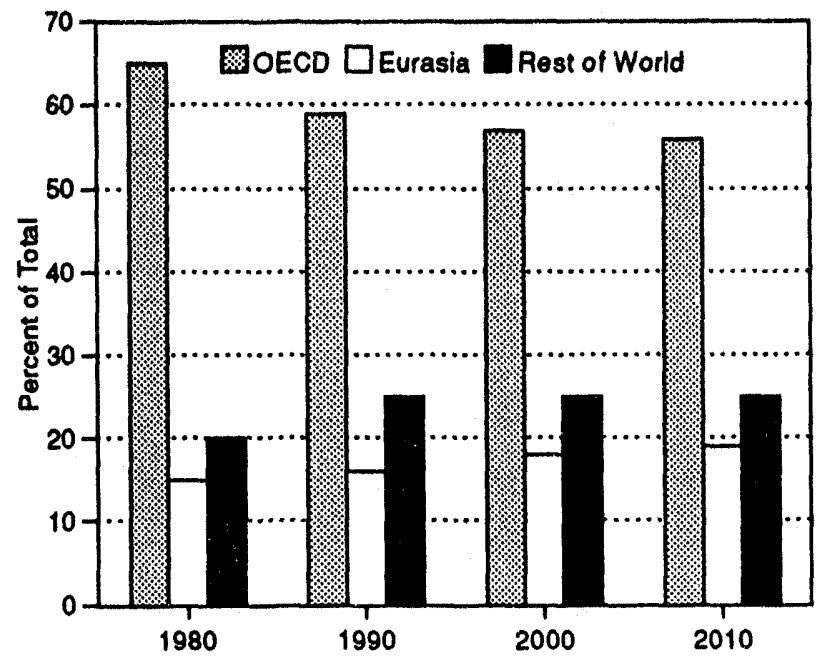

Sources: History: Energy Information Administration, International Energy Annual 1992, DOE/EIA-0219(92), Table A13 and related data base. Projections: Table A7.

to grow fastest in Japan and Canada in the OECD and China in Eurasia (Figure 37).

\section{Hydroelectricity}

Where appropriate natural conditions exist to make it feasible, governments of many developing countries consider hydroelectricity an important vehicle to guarantee a secure source of electricity and, thereby, to ensure continued economic development and an accompanying rise in living standards. The development of hydroelectricity is, nevertheless, constrained by the high costs associated with installation (which include building dams and rerouting water passages) and by recent concerns over effects of hydroelectric facilities on the environment.

\section{Current Status}

A number of hydroelectric power projects are currently underway throughout the developing world; and development is likely to be substantial in the Rest of World (ROW) countries and China during the projection decades. In fact, the Chinese government has announced plans to build five hydroelectric dams by the year 2000, including the Three Gorges Project [3, p. 13]; a \$20-billion 18,000-megawatt project. A major objective in that country is to provide rural electrification to regions that are now deficient in energy [31, p. 115].
Figure 37. Consumption of Hydroelectricity and Other Renewable Energy by Major Country Grouplings, 1980-2010

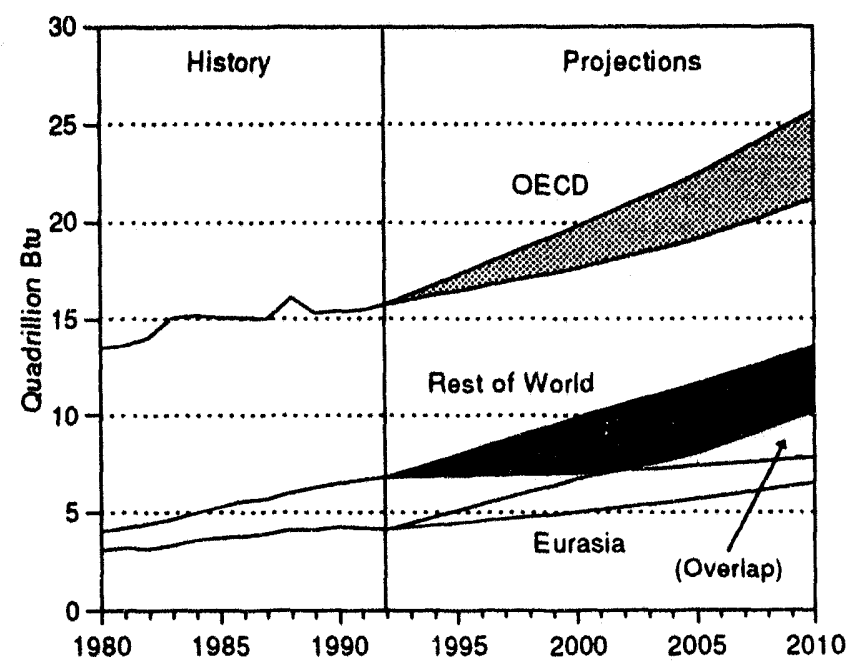

Sources: History: Energy Information Administration, International Energy Annual 1992, DOE/EIA-0219(92), Table A13 and related data base. Projections: Table A7.

In Central and South America, hydroelectricity is the second largest contributor to the energy supply of the region (exceeding natural gas, coal, and nuclear power); it was responsible for 27 percent of all primary energy there in 1992 [11, pp. 118-124]. The development potential for hydroelectricity is greatest in Brazil, Colombia, Venezuela, and Argentina; and these countries have strategic policies to increase the already significant share of total electricity output it provides. Brazil is currently expanding two major hydroelectric plants, including the Itaipu station (a joint effort with Paraguay) which is already the largest hydroelectric dam project in the world [31, pp. 140-141]. These two plants will have a combined capacity of 20,000 megawatts. Brazil gets 96 percent of its electricity from its rivers now, and is continuing hydroelectric development despite growing opposition from environmental groups [48, p. 62].

Some countries in the Asia-Pacific region-including Indonesia, Malaysia, Nepal, the Philippines and Pakistan-are at various stages in developing hydroelectric facilities. The major constraint for these relatively poor nations appears to be in securing finances for development, although another difficulty is obviously the potential impact on local populations and the environment. For instance, the Victoria Dam project (part of the Mahaweli hydroelectric and irrigation program in Sri Lanka) was expected at first to displace 1,300 families, 
but actually about four times that many had to be resettled [40, p. 13]. In some island nations, such as Indonesia and Malaysia, hydroelectric development is possible, but primarily on remote islands where the power is not needed presently [31, p. 104].

In Africa, almost two-thirds of the hydroelectricity produced in 1989 could be attributed to only five countries: Egypt, Ghana, Mozambique, Zaire, and Zambia [31, p. 93]. Development projects for Africa include joint development by Zaire and Zambia along the Zambezi River. Kenya expects to add 140 megawatts of capacity by 1995 [31, p. 93]. A $\$ 300$ million power plant expansion project was formalized in Liberia in 1990. Delays in the Liberian project have been attributed to the continuing civil war; once started, the 104-megawatt power plant should take 4 years to complete [53, p. 27].

Physical conditions in the Middle East make hydroelectric development and current supply insignificant. Hydroelectricity in that region currently exists only in Iran, Iraq, Syria, and Lebanon [31, p. 149].

Hydroelectricity is considered a mature industry in the OECD countries, in that most practical potential hydroelectric resources in these regions have been developed. It will become more difficult to find suitable sites for new hydroelectric plants, considering the amount of land often required to develop the resource.

Unfavorable natural conditions combine with capital shortages in most of Eastern Europe to make substantial hydroelectric development unlikely [31, pp. 127128]. Although natural conditions are appropriate for hydroelectric power in the former Yugoslavia, civil war there has, of course, diminished its potential development [31, pp. 127-128]; and even the survival of existing facilities is at issue in this region. In February 1993, Serbian forces detonated mines around the Peruca hydroelectric dam in the Croatian city of Split, damaging the facility beyond repair $[60, p .18]$.

The largest projects currently under construction in Eastern Europe are on the Hungarian/Czech segment of the Danube. The Hungarian Nagymoros Dam (originally part of a joint venture with the former Czechoslovakia) was stopped in 1988 for environmental reasons; but work was completed on the Slovakian dam in October 1992 in spite of strong local and international opposition. Without Hungarian cooperation, the hydroelectric project at the Slovakian city of Gabcíkovo is expected to generate only about 180 megawatts of electricity -far below the 780 megawatt capacity envisioned in the original plan. Although
Hungary wishes to stop any diversion of the Danube into this dam project, the Slovak Republic believes that abandoning the project at this late stage would be more costly in terms of finance and environmental damage than completing the project [50, p. 36].

The former Soviet Union (FSU) has substantial hydro potential (up to 270 gigawatts), but development in the nations that make up the FSU is not expected to be extensive, because two-thirds of their substantial potential lies in the eastern regions-far from major load centers [31, p. 160]. Nevertheless, the governments of Tajikistan and Kyrgyzstan are actively seeking funding for hydroelectric projects [2, p. 27, and 43, p. 7]. Tajikistan is 90 percent mountainous, with a large number of rivers giving the country enormous potential for hydroelectric generation-second only to Russia itself [43, p. 7]. In Kyrgyzstan, where hydroelectric power accounts for 80 percent of all present electricity production, the government estimates that "only 9 percent of total hydropower resources have been exploited to date" [2, p. 27].

\section{Financial Concerns}

In developing countries where the necessary natural conditions exist, hydroelectricity is seen as an important factor toward securing an independent source of energy and, thereby, maintaining economic growth. However, many of the poorer nations which would benefit from hydroelectricity, find obtaining the initial financial investment required for such development difficult.

Costs of installing hydroelectric facilities generally run into the hundreds of millions of dollars, often requiring developing nations to incur large debt to develop the structures. In Brazil, for example, 40 percent of the total foreign debt of 100 billion dollars is attributed to Brazilian electric utilities [48, p. 62]. However, it is argued that in the long-term, without such development, nations that cannot guarantee an uninterrupted electric power supply will find it impossible to attract the industry essential for continued economic growth. The large startup costs may thereby justify the development of this operationally inexpensive energy source.

\section{Environmental Issues}

Increasingly, hydroelectric projects face numerous environmental issues which, along with the considerable financial investment required to build a hydroelectric installation, may constrain development of the resource. Environmental problems associated with hydroelectric facilities include salinization of river deltas, erosion, and siltation of dams (31, pp. 166-167). The elimination of agricultural land, depletion of avail- 
able drinking water, pollution resulting from dams, and the displacement of large numbers of people from areas that must be flooded to provide water flow to the dams are also subjects of concern that have been affecting the amount of planned construction since the 1980's.

In Canada, various groups have actively protested the proposed James Bay II hydroelectric projects citing the high methyl mercury levels found in the fish population of the nearby James Bay I hydro project and studies which suggest that the water vapor evaporated from hydroelectric reservoirs may be as significant a source of greenhouse gases as carbon emissions from fossil fuel plants [42, pp. 50-52].

Protests against hydroelectric dams have also emerged in the Asia-Pacific region, despite the fact that the governments involved generally consider secure energy resources essential for economic development. In China, for instance, the proposed Three Gorges Project has been postponed several times, in part because of criticism from the local population who express fears that more than 1 million people could be displaced by the proposed dam site [49, pp. 58-59]. The collapse of China's Gouhou hydroelectric dam last August exacerbated this opposition, yet the eventual construction of Three Gorges seems inevitable.

\section{Geothermal Energy}

Persistently competitive prices and abundant supplies of fossil fuels have slowed the development of renew- able resources other than hydroelectricity. Geothermal energy and the remaining renewable sources (wind, biomass, and solar power) remain a very small percentage of the world's total electric installed capacity. They currently represent only 1.6 percent of the hydro-plusother installed capacity (Table 10). However, concerns about itse effects of fossil-fuel use on the environment have prompted some increased $R \& D$ investment in all of these renewable sources around the world.

Geothermal energy is making only modest gains on a year-to-year basis. In some respects (such as the "hot dry rocks" technology, which would greatly extend the geographical areas in which geothermal energy might be useful), it remains primarily a subject for further research and development (R\&D). It cannot be expected to make significant contributions to total worldwide electricity production in the near future.

Countries interested in geothermal power must have the natural conditions necessary to develop it, and even then the potential output is limited so long as geothermal steam and naturally occurring geothermal hot water are the only sources that can be tapped economically. Japan, for example, has benefitted from an abundance of geothermal energy; and-beginning in 1973 with the start of the Arab oil embargo-the Japanese government has continued to support the development of geothermal energy as an alternative energy source [22, p. 42]. Japan hopes to double its present installed capacity of 270 megawatts within the next few years, but that level would still represent

Table 10. World Electriclty Installed Capacity for Hydroelectricity and Other Renewable Sources, 1992 (Million Kilowatts as of January 1, 1992)

\begin{tabular}{|c|c|c|}
\hline Country/Region & Hydroelectricity & $\begin{array}{l}\text { Geothermal and Other" } \\
\text { Renewable Energy Resources }\end{array}$ \\
\hline United States $\ldots \ldots \ldots \ldots \ldots \ldots \ldots$ & 92.0 & 1.6 \\
\hline Canada $\ldots \ldots \ldots \ldots \ldots \ldots \ldots$ & 60.2 & -. \\
\hline $\operatorname{Japan} \ldots \ldots \ldots \ldots \ldots \ldots \ldots$ & 39.1 & 0.3 \\
\hline OECD Europe $\ldots \ldots \ldots \ldots \ldots \ldots$ & 158.3 & 1.4 \\
\hline China...$\ldots \ldots \ldots$ & 38.0 & -. \\
\hline Former Soviet Union $\ldots \ldots \ldots \ldots \ldots \ldots$ & 65.0 & -- \\
\hline Eastern Europe . . . . . . . . . . . & 22.1 & .. \\
\hline Middle East $\ldots \ldots \ldots \ldots \ldots \ldots \ldots$ & 3.1 & -. \\
\hline Africa $\ldots \ldots \ldots \ldots \ldots \ldots \ldots \ldots$ & 19.5 & 0.1 \\
\hline Far East and Oceaniab $\ldots \ldots \ldots \ldots$ & 56.4 & 1.2 \\
\hline Latin America $\ldots . \ldots \ldots \ldots \ldots \ldots$ & 98.7 & 5.5 \\
\hline World Total. & 652.5 & 10.1 \\
\hline
\end{tabular}

${ }^{a}$ Other consists of solar, biomass, wind, and other renewable sources.

'Excluding China and Japan.

Source: Energy Information Administration, International Energy Annual 1992, DOE/EIA-0219(92), Table 31. 
merely a tiny fraction of the country's total electricity demand.

Other countries currently investing in and developing geothermal energy include Canada, Mexico, Indonesia, and New Zealand. Most interest in hot dry rocks (HDR) research is in the United Kingdom, United States, Japan, Sweden, France, and Germany. Research projects in the United Kingdom have had disappointing results, and independent R\&D funding has been declining in recent years, with future funds expected to be redirected to include other European countries [35, p. 27]. However, high costs and various technical problems may retard sizable development.

In general, government financial support of geothermal energy is needed to encourage continuing $R \& D$. The Japanese government uses budget measures, treasury investment and loans, and taxation to fund its continued support of geothermal energy development [1, p. 46]. In the United States, the Energy Policy Act of 1992 (EPACT) provides for a permanent 10-percent investment tax credit for both solar and geothermal projects.

\section{Other Renewable Energy Sources}

The other renewable energy sources including wind, biomass, and solar power remain, like geothermal energy, an object of further R\&D. Increased investment in these renewable sources is especially evident in OECD Europe where the windpower industry, in particular, is currently enjoying some fast-paced growth. In the United States, development of the other renewable sources should more than double over the projection period, with most of the growth taking place after 2005 [8, p. 26].

Between 1982 and 1992, the supply of energy from wind power grew from 37 megawatts to 1,000 megawatts in the European Community (EC) [59, p. 81]. Presently, the EC expects to install more than 3,000 megawatts of new wind energy by 2000 [34, p. 45]. By comparison, the United States generated 1,700 megawatts from wind power in 1992 [59, p. 81]. Germany, the Netherlands, and Denmark boast the world's largest wind development programs [21, p. 586], and large wind projects are also planned for Italy, Spain, and the United Kingdom (4, p. 37).

Presently, the EC spends more money on R\&D for wind power than any other part of the world (about 10 times as much as this country) (34, p. 45). Between 1986 and 1989, the Danish government invested 66 million ecus (about $\$ 73$ million) in windpower companies which now generate half of all the windpower in the EC. The United Kingdom uses "a fiftieth of electricitytax revenues" for R\&D on renewable energy sources, including windpower [59, p. 81].

Beyond OECD Europe and the United States, little wind power development is going on right now. The World Bank expects to finance wind projects in Mexico, India, and Indonesia [58, p. 99|, however, and U.S. wind companies are looking to China and Eastern Europe as future markets [18, p. 42].

Most use of biomass energy today occurs in the developing countries-in the form of burning wood for cooking and heating [26, pp. 113-114]. In addition, the use of fuels derived from vegetable matter is becoming more common. Half of the vehicle fuel in Brazil is supplied by alcohol from sugar cane [52, p. :3]. Insofar as the industrialized nations are concerned, Sweden and Finland currently produce about 16 percent of all the primary energy they consume from trees and waste [4, p. 36], and these two countries (plus Denmark) continue R\&D in "biofuels" [4, p. 36, and 56, p. 44].

Solar power is presently considered economically impractical for much of the industrialized world, but it is competitive in remote areas away from major electric grids-a common circumstance in many developing countries [59, p. 81]. Although their combined output is small, an estimated 100,000 solar-power systems are now in use in developing countries. For example, solar projects have been financed in the Dominican Republic, Sri Lanka, and Zimbabwe. The World Bank is considering prospects for future solar rural electrification projects in India, Sri Lanka, and Indonesia [46, pp. 692-692]. 


\title{
Environmental Considerations
}

\author{
The Rio Convention pledges global cooperation in stabilizing \\ carbon emissions pushed by growth trends in the developing world.
}

Concern for the environment has become a major focus internationally. Citizens throughout the world would like to eliminate dangerous and unesthetic pollution, to protect and improve the quality of life, and to safeguard the environment for their descendants. One current environmental issue of direct relevance in any international energy outlook is the possibility of anthropogenic (human-induced) climate change, because the largest share of greenhouse gases produced by human activities (see box) comes from the production and use of energy.

The contribution of greenhouse gas concentrations from all human activities (such as fossil fuel combustion and industrial processes) is very small in comparison to releases from natural factors, such as the combustion of vegetation in wildfires and the biological processes of animals and microbes. Nevertheless, scientists from the National Academy of Sciences and the Intergovernmental Panel on Climate Change (IPCC) believe that increased greenhouse gas concentrations in the atmosphere could cause a major change in the Earth's climate by raising average global temperatures noticeably as early as the middle of the next century. Scientists as a whole are still sharply divided on this issue and on the magnitude of the possible effects [5, p. 6].

The major greenhouse gases are carbon dioxide, nitrous oxide, methane, halocarbons, and water vapor. All of these except halocarbons occur naturally. Anthropogenic carbon dioxide is emitted primarily in the burning of fossil fuels such as coal, petroleum, and natural gas. Although coal releases the highest volume of carbon dioxide per unit of fuel consumed, the larger amounts of oil used as energy sources around the world make the latter fuel a larger overall contributor of carbon emissions (Figure 38). Natural gas ranks behind both coal and oil in absolute terms and in releases per unit of energy.

Three-fourths of all anthropogenic carbon dioxide released to the atmosphere can be traced to the energy sector [29, p. 98]. When a fossil fuel is burned, almost

\section{Figure 38. World Carbon Emissions by Fuel Type, 1990-2010}

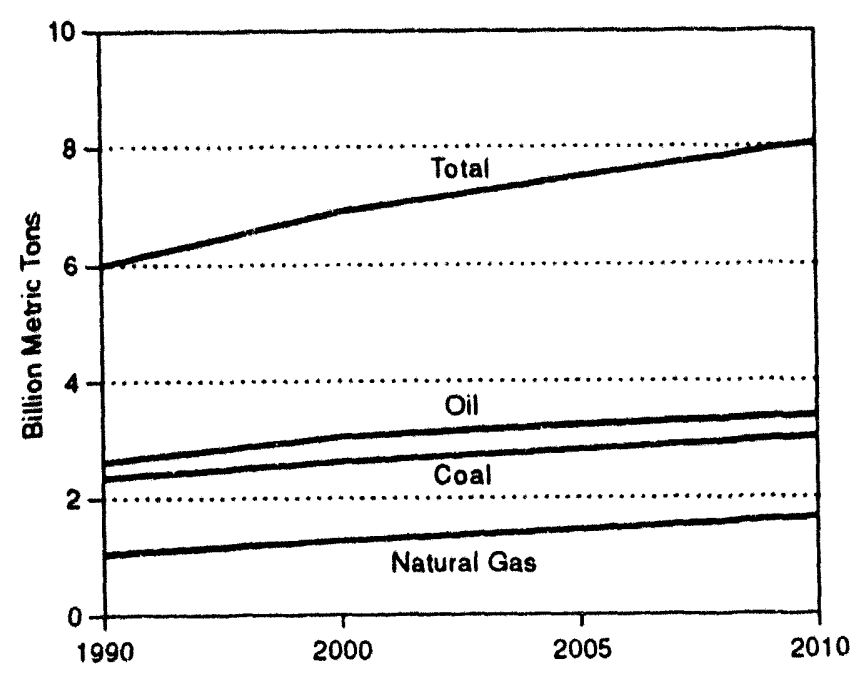

Sources: History: Energy Information Administration, Annual Energy Outlook 1994, DOE/EIA-0383(94), Table A17; Emissions of Greon. house Gases in the United States, 1985-1990, DOE/EIA.0573, Table 7; and derived from International Energy Annual 1992, DOE/EIA. 0219(82), Tables A1O, A11, and $A 12$ and carbon coefficients presented in Emissions of Greenhouse Gases in the United States, 1985-1990, DOE/EIA-0573, p. 15. Projections: Table 11.

all of its carbon content combines with oxygen in the atmosphere to form carbon dioxide. For every ton of fossil fuel burned, at least three-quarters of a ton of carbon is released as carbon dioxide $[10, p p . i x-x]$.

\section{Projections}

Figure 39 depicts changes between 1990 and 2010 in gross domestic product (GDP), energy consumption, and carbon emissions for the world, using an index based on 1990 levels for each indicator. World GDP is expected to grow by 71 percent between 1990 and 2010, while energy consumption and carbon emissions are expected to grow by 38 and 35 percent, respectively, above their 1990 levels. The slower growth of consumption compared to GDP may be explained by energy intensity gains. Increased use of renewable fuels and 
Flgure 39. World Tronds: Economic Growth, Enorgy Consumption, and Carbon Emissions, 1990-2010

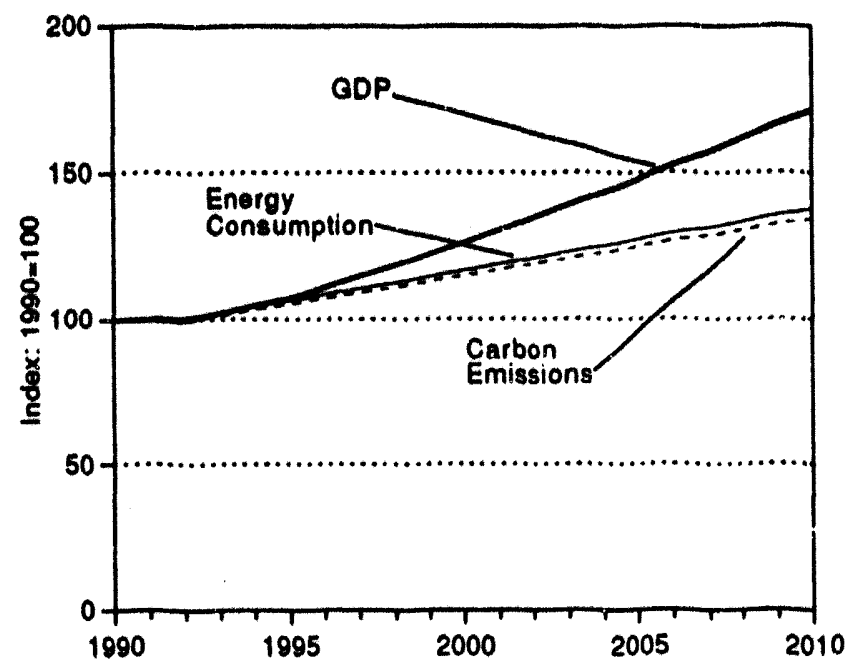

Sources: Derived using Tables 11 and A1. GDP from the WEFA Group, Wortd Economic Service and World Economic Service Historical (June 1992) and World Economic Outlook (February and July 1993).

faster growth in the use of natural gas, compared to oil or coal, are the reasons that carbon emissions growth is expected to be slower than growth in energy consumption throughout the projection period.

Currently, countries of the Organization for Economic Cooperation and Development (OECD) are responsible for about half of all energy-related carbon emissions. OECD emissions during 1992 were measured at nearly 3 billion metric tons of carbon (Table 11 and Figure 40). Carbon emissions for these countries are projected to increase slowly through 2010 (at approximately 1.2 percent per year between 1990 and 2010).

The OECD share of total world carbon emissions is expected to remain close to 50 percent until after 1995, when the non-OECD countries are expected to begin increasing their share of emissions (Figure 41). In fact, the OECD share is expected to drop from 49 percent in 1992 to 45 percent in 2010.

One reason for the increase in the non-OECD share of carbon emissions is that consumption in the non-OECD countries is expected to actually exceed that of the OECD countries before 2010 (Figure 42). A drop in the non-OECD energy consumption share and a corresponding drop in emissions in the early to mid-1990's is explained by the political and social upheaval in the former Soviet Union (FSU) and Eastern Europe. In these
Figure 40. World Carbon Emisslons by Reglon, 1990-2010

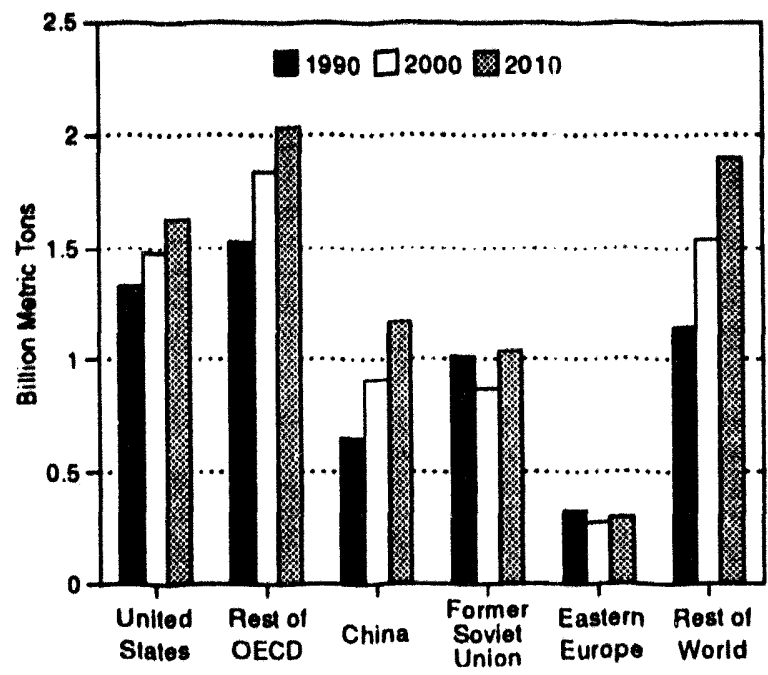

Sources: History: Energy Intormation Administration, Annual Energy Outlook 1994, DOE/EIA-0383(94), Table A17; Emissions of Greenhouse Gases in the United States, 1985.1990, DOE/EIA-0573, Table 7; and derived from International Energy Annual 1992, DOE/EIA. $0219(92)$, Tables $A 10, A 11$, and $A 12$ and carbon coefficients presented in Emissions of Greenhouse Gases in the United States, 1985. 1990, DOE/EIA.0573, p. 15. Projections: Tabli 11.

Flgure 41. Carbon Emissions: OECD vs. NON-OECD

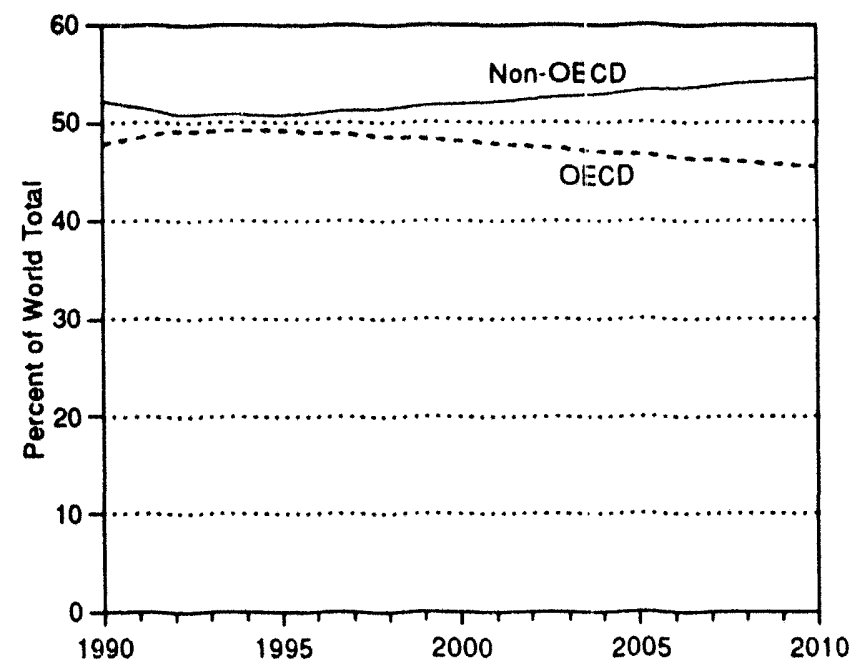

Source: Derived from Table 11.

two regions combined, emissions dropped by 17.5 percent between 1990 and 1992-from 1,338 million metric tons to 1,105 million metric tons (Table 11). Carbon emissions from both areas are expected to drop further through 1995. In the FSU, they should regain their 1990 
Table 11. Total World Carbon Emisslons, 1990-2010

(Million Metric Tons)

\begin{tabular}{|c|c|c|c|c|c|c|c|c|c|c|c|}
\hline \multirow[b]{3}{*}{ Region/Country } & \multirow{2}{*}{\multicolumn{2}{|c|}{ Hiatory }} & \multicolumn{9}{|c|}{ Projections } \\
\hline & & & \multicolumn{3}{|c|}{2000} & \multicolumn{3}{|c|}{2005} & \multicolumn{3}{|c|}{2010} \\
\hline & \multirow[t]{2}{*}{1990} & \multirow[t]{2}{*}{1092} & \multirow[t]{2}{*}{$\begin{array}{l}\text { Base } \\
\text { Caseo } \\
\end{array}$} & \multicolumn{2}{|c|}{$\begin{array}{c}\text { Sonsittivity } \\
\text { Range }\end{array}$} & $\begin{array}{l}\text { Base } \\
\text { Case }\end{array}$ & \multicolumn{2}{|c|}{$\begin{array}{c}\text { Sonsitivity } \\
\text { Range }\end{array}$} & $\begin{array}{l}\text { Base } \\
\text { Case }\end{array}$ & \multicolumn{2}{|c|}{$\begin{array}{c}\text { Sonsitivity } \\
\text { Range }\end{array}$} \\
\hline \multicolumn{9}{|l|}{ OECD } & & & \\
\hline United States & 1,338 & 1,341 & 1,483 & 1,454 & 1,514 & 1,553 & 1,513 & 1,597 & 1,632 & 1,566 & 1,702 \\
\hline$\ldots \ldots \ldots \ldots \ldots \ldots$ & 130 & 134 & 158 & 143 & 175 & 164 & 146 & 187 & 168 & 145 & 192 \\
\hline$\ldots \ldots \ldots \ldots \ldots$ & 310 & 320 & 395 & 353 & 460 & 425 & 343 & 517 & 443 & 343 & 545 \\
\hline OECD Europo & 995 & 1,042 & 1,184 & 1,115 & 1,273 & 1,253 & 1,154 & 1,379 & 1,314 & 1,192 & 1,455 \\
\hline United Kingdom & 164 & 174 & 207 & 188 & 230 & 218 & 189 & 251 & 230 & 195 & 269 \\
\hline France & 112 & 119 & 133 & 113 & 156 & 140 & 110 & 175 & 147 & 107 & 191 \\
\hline$\ldots \ldots \ldots \ldots$ & 265 & 254 & 292 & 257 & 335 & 311 & 261 & 369 & 3 & 266 & 393 \\
\hline$\ldots \ldots \ldots \ldots \ldots$ & 118 & 120 & 136 & 122 & 153 & 143 & 124 & 166 & 148 & 125 & 174 \\
\hline Netherlar & 59 & 62 & 68 & 63 & 74 & 71 & 64 & 79 & 72 & 64 & 80 \\
\hline On & 274 & 312 & 346 & 323 & 374 & 370 & 333 & 413 & 392 & 343 & 444 \\
\hline Other OECD . & 92 & 96 & 106 & 101 & 112 & 112 & 103 & 122 & 115 & 105 & 129 \\
\hline Total OECD . & 2,865 & 2,932 & 3,326 & 3,216 & 3,488 & 3,507 & 3,330 & 3,734 & 3,672 & 3,449 & 3,929 \\
\hline \multicolumn{12}{|l|}{ Eurasia } \\
\hline China. & 649 & 678 & 907 & 803 & 1,017 & 1,040 & 870 & 1,223 & 1,170 & 935 & 1,435 \\
\hline Former Sov & 1,014 & 868 & 868 & 802 & 931 & 950 & 840 & 1,065 & 1,037 & 870 & 1,209 \\
\hline Eastern E & 325 & 236 & 272 & 245 & 295 & 285 & 249 & 320 & 297 & 249 & 346 \\
\hline Total Euresia & 1,987 & 1,783 & 2,047 & 1,889 & 2,207 & 2,275 & 2,010 & 2,551 & 2,504 & 2,124 & 2,918 \\
\hline \multicolumn{12}{|l|}{ Rest of World (ROW) } \\
\hline Middle Ea & 204 & 221 & 273 & 257 & 294 & 303 & 269 & 362 & 329 & 290 & 425 \\
\hline Africa & 193 & 216 & 245 & 226 & 266 & 263 & 231 & 310 & 280 & 241 & 355 \\
\hline Asia . & 474 & 530 & 668 & 619 & 727 & 763 & 667 & 904 & 855 & 725 & 1,087 \\
\hline Latin America & 275 & 286 & 353 & 335 & 377 & 395 & 360 & 464 & 434 & 389 & 555 \\
\hline Total ROW & 1,147 & 1,252 & 1,539 & 1,437 & 1,665 & 1,723 & 1,527 & 2,040 & 1,899 & 1,645 & 2,422 \\
\hline World Total . & $\mathbf{5 , 9 9 9}$ & 5,868 & 6,911 & 6,636 & 7,264 & 7,505 & 7,041 & 8,140 & 8,075 & $\mathbf{7 , 4 5 2}$ & 9,001 \\
\hline
\end{tabular}

OECD = Organization for Economic Cooperation and Development.

Note: The U.S. numbers include carbon emissions attributable to renewable energy sources.

Sources: The U.S. numbers were taken from Energy Information Administration, Emissions of Greenhouse Gases in the United States 1985-1990, DOE/EIA-0573, Table 7; and Annual Energy Outlook 1994, DOE/EIA-0383(94), Tables A17, B17, and C17. History and Projections-Derived from Tables 12, 13, and 14.

levels by 2010, but in Eastern Europe they are projected to stay well below their 1990 levels through 2010.

The mix of energy sources used by OECD and nonOECD countries also explains the differences in their shares of carbon emissions. Non-OECD countries use more fossil fuels relative to nuclear or hydroelectric power. As a result, non-OECD countries could generate more emissions (Figure 41) and yet consume less total energy than the OECD countries through 2005 (Figure 42). In addition, the OECD countries will increasingly rely on natural gas as opposed to the heavier-polluting coal. Although carbon emissions in the OECD grow by 20 and 24 percent between 1990 and 2010 for coal and oil, respectively, emissions attributed to natural gas are expected to grow by 57 percent across this time span (Tables 12, 13, and 14).

While the OECD share of total carbon emissions is decreasing, its fossil fuel consumption (oil, natural gas, and coal) per capita is high when compared with the non-OECD level. In fact, if non-OECD countries consumed as much energy per capita as the OECD countries, the carbon outlook in 2010 would be much worse; non-OECD countries would consume about five times more energy than the current estimate of 216 quadrillion Btu (Figure 43). Emissions would be worse still if non-OECD countries consumed energy at the same per 
Figure 42. Energy Consumption: OECD v8. NON-OECD

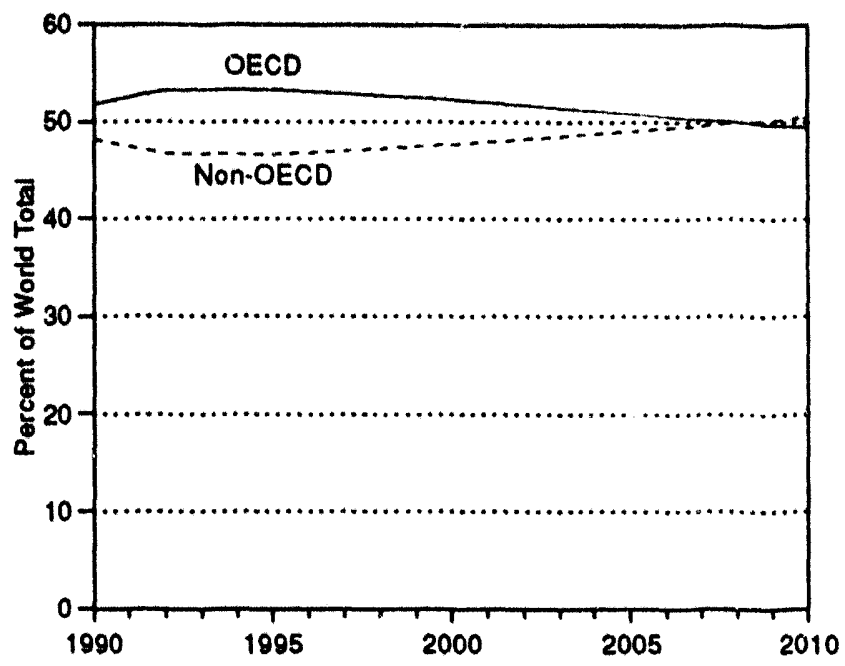

Source: Derived from Table A1.

\section{Figure 43. Economic Development and World Fossil Fuel Consumption}

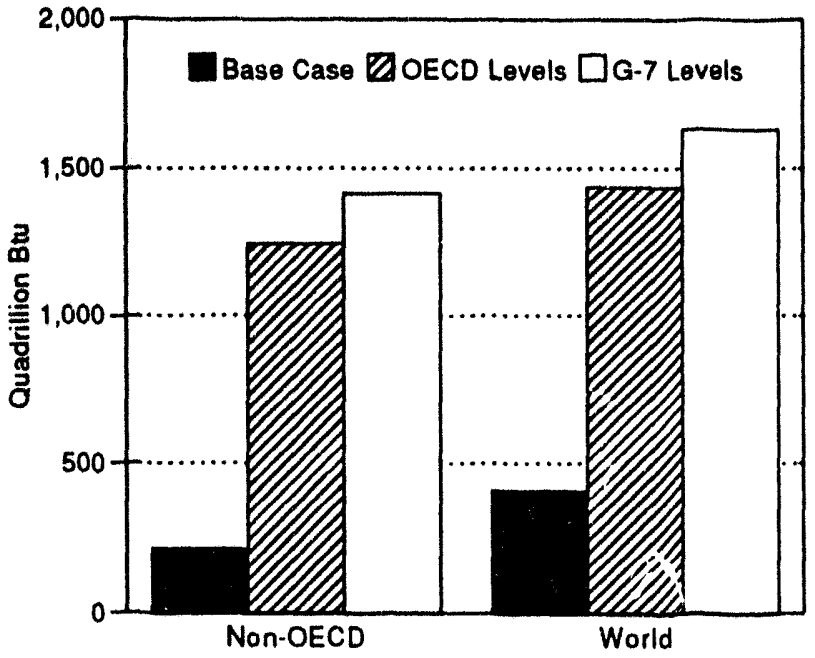

Sources: Derived from the World Energy Projection System, 1994 and United Nations, The Sex and Age Distribution of the World Populations: The 1992 Revision (Now York, 1993).

capita level as countries that make up the G-7 (United States, Japan, Canada, United Kingdom, France, Germany, and Italy).

There is considerable variety in the levels of carbon emissions per capita among the major industrialized countries (Figure 44). Among the G-7 countries, the United States retains the highest per person rate over the entire projection period. However, emissions do remain stable in the United States, whereas in every other G-7 country (except Canada) emissions are projected to increase (albeit slowly) through 2010.

In the G-7 countries, carbon emissions remain relatively stable as fossil fuels hold or increase (in the case of natural gas) their share of total energy consumption (Figure 45). Natural gas-a cleaner fuel than either oil or coal-is expected to gain a 3-percent share of total

\section{Flgure 44. Carbon Emissions per Caplta}

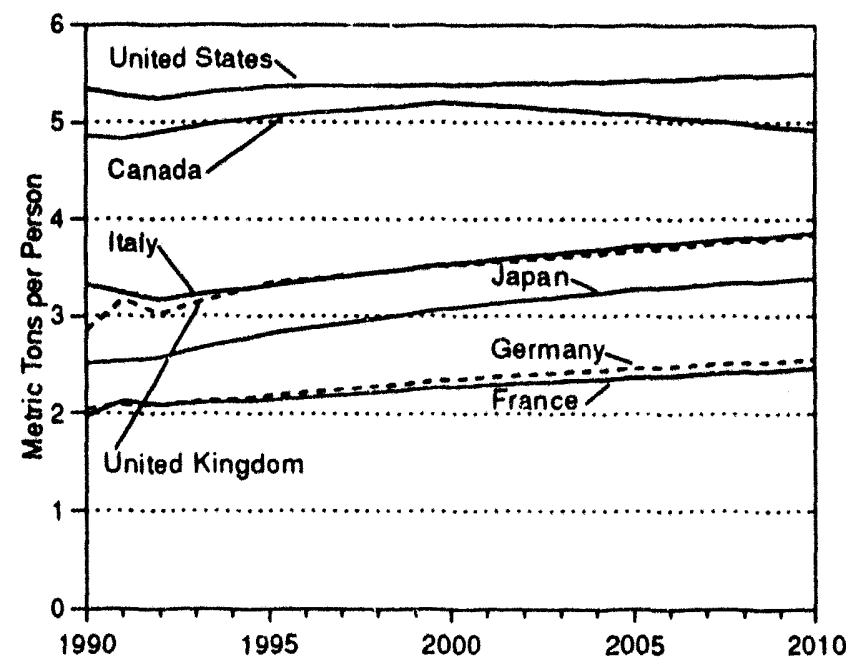

Sources: Derived from Table 11 and population data from United Nations, The Sex and Age Distribution of the World Populations: The 1992 Revision (New York, 1993).

Figure 45. G-7 Energy Consumption by Fuel Type

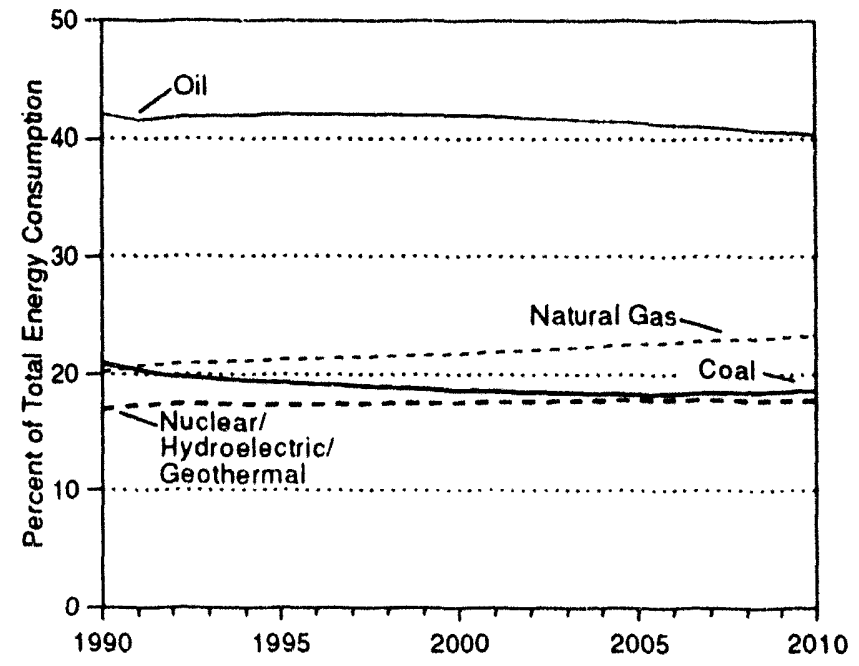

Sources: History: Energy Information Administration (EIA). International Energy Annual 1992, DOE/EIA-0219(92). Projections: EIA, World Energy Projection System, 1994. 
Table 12. Carbon Emissions from Oll, 1990-2010

(Million Metric Tons)

\begin{tabular}{|c|c|c|c|c|c|c|c|c|c|c|c|}
\hline \multirow[b]{3}{*}{ Reglon/Country } & \multirow{2}{*}{\multicolumn{2}{|c|}{ History }} & \multicolumn{9}{|c|}{ Projections } \\
\hline & & & \multicolumn{3}{|c|}{2000} & \multicolumn{3}{|c|}{2005} & \multicolumn{3}{|c|}{2010} \\
\hline & \multirow[t]{2}{*}{1990} & \multirow[t]{2}{*}{1992} & $\begin{array}{l}\text { Base } \\
\text { Case }\end{array}$ & $\begin{array}{l}\text { Sensit } \\
\text { Ran }\end{array}$ & $\begin{array}{l}\text { ivity } \\
\text { go }\end{array}$ & $\begin{array}{l}\text { Base } \\
\text { Case }\end{array}$ & $\begin{array}{l}\text { Sensi } \\
\text { Ran }\end{array}$ & $\begin{array}{l}\text { ivity } \\
\text { ge }\end{array}$ & $\begin{array}{l}\text { Base } \\
\text { Case }\end{array}$ & $\begin{array}{l}\text { Sonsi } \\
\text { Ran }\end{array}$ & \\
\hline \multicolumn{10}{|l|}{ OECD } & & \\
\hline United States & 583 & 575 & 645 & 633 & 669 & 674 & 654 & 710 & 695 & 669 & 740 \\
\hline Canada & 67 & 64 & 73 & 70 & 80 & 74 & 69 & 83 & 74 & 67 & 82 \\
\hline Japan. & 207 & 220 & 273 & 261 & 298 & 288 & 264 & 319 & 291 & 259 & 320 \\
\hline OECD Europe & 532 & 561 & 638 & 617 & 680 & 654 & 620 & 710 & 657 & 616 & 711 \\
\hline United Kingdom $\ldots \ldots \ldots \ldots$ & 71 & 73 & 83 & 80 & 88 & 85 & 81 & 92 & 85 & 80 & 92 \\
\hline France $\ldots \ldots \ldots \ldots \ldots \ldots$ & 74 & 79 & 89 & 86 & 95 & 92 & 87 & 99 & 92 & 86 & 100 \\
\hline$\ldots \ldots \ldots \ldots \ldots$ & 109 & 116 & 132 & 128 & 141 & 136 & 129 & 147 & 136 & 128 & 147 \\
\hline$\ldots \ldots \ldots \ldots \ldots$ & 79 & 82 & 93 & 90 & 99 & 96 & 91 & 104 & 96 & 90 & 104 \\
\hline$\ldots \ldots \ldots \ldots$ & 31 & 32 & 36 & 35 & 39 & 37 & 35 & 40 & 37 & 35 & 40 \\
\hline Other Europe & 169 & 179 & 204 & 197 & 217 & 209 & 198 & 227 & 210 & 197 & 227 \\
\hline Other OECD .. & 41 & 41 & 48 & 46 & 50 & 51 & 49 & 55 & 53 & 50 & 59 \\
\hline Total OECD $\ldots \ldots \ldots \ldots \ldots$ & 1,430 & 1,461 & 1,677 & 1,630 & 1,770 & 1,741 & 1,661 & 1,867 & 1,770 & 1,669 & 1,899 \\
\hline \multicolumn{12}{|l|}{ Eurasia } \\
\hline China . & 99 & 113 & 137 & 120 & 154 & 154 & 129 & 176 & 172 & 141 & 202 \\
\hline Former Soviet Union & 350 & 280 & 259 & 226 & 288 & 284 & 242 & 330 & 313 & 255 & 368 \\
\hline Eastern Europe $\ldots$ & 71 & 47 & 56 & 47 & 65 & 65 & 52 & 73 & 73 & 60 & 86 \\
\hline Total Eurasia $\ldots \ldots \ldots \ldots$ & 520 & 439 & 452 & 393 & 507 & 503 & 423 & 579 & 558 & 456 & 655 \\
\hline \multicolumn{12}{|l|}{ Rest of World (ROW) } \\
\hline Middle East $\ldots \ldots$ & 146 & 155 & 195 & 191 & 204 & 212 & 206 & 242 & 227 & 218 & 288 \\
\hline Africa $\ldots \ldots \ldots$ & 87 & 93 & 116 & 114 & 122 & 127 & 123 & 145 & 136 & 130 & 172 \\
\hline Asia $\ldots \ldots \ldots \ldots$ & 226 & 264 & 331 & 325 & 346 & 360 & 349 & 411 & 385 & 371 & 489 \\
\hline Latin America & 208 & 214 & 269 & 264 & 281 & 292 & 284 & 333 & 313 & 301 & 397 \\
\hline Total ROW $\ldots . . . \ldots \ldots$ & 666 & 727 & 911 & 894 & 953 & 991 & 961 & 1,131 & 1,060 & 1,020 & 1,346 \\
\hline World Total & 2,617 & 2,627 & 3,040 & 2,920 & 3,230 & 3,235 & 3,048 & 3,571 & 3,389 & 3,149 & 3,886 \\
\hline
\end{tabular}

OECD = Organization for Economic Cooperation and Development.

Sources: The U.S. numbers were taken from Energy Information Administration (EIA), Emissions of Greenhouse Gases in the United States 1985-1990, DOE/EIA-0573, Table 7; and Annual Energy Outlook 1994, DOE/EIA-0383(94), Tables A17, D17, and E17. History-Derived from EIA, International Energy Annual 1992, DOE/EIA-021(92) (1994), and carbon coefficients in Emissions of Greenhouse Gases in the United States 1985-1990, DOE/EIA-0573, Table 11, p. 15. Projectione-EIA, World Energy Projecriun System, 1994.

energy consumption between 1990 and 2010 in the G-7 countries helping to limit the growth of emissions.

The largest amount of growth in GDP, population, and energy consumption will occur in the developing countries, contributing to the largest growth in carbon emissions as well (Figures 46 and 40). Coal consumption in China is the major contributor to this change (Table 14). In China, total carbon emissions are expected to increase by an average of 3 percent per year between 1990 and 2010. Carbon emissions in the developing, Rest of World (ROW) countries are expected to grow by 2.6 percent per year on average during the same time span, with oil the major contributor in this case (Table 12). Improvements in energy intensity should, to some degree, limit the growth of energy consumption and, therefore, carbon emissions.

Comparisons of economic development (measured as GDP per capita) to national energy use patterns (measured as Btu per dollar of GDP) suggest that the highest levels of economic development will not be associated with the highest levels of energy use (Figure 47). Shifts in economic structure away from energyintensive heavy manufacturing toward less energyintensive services and high-technology industries also 
lead to higher GDP per capita. The positions of the United States and Japan as compared with China clearly illustrate this relationship (Figure 47).

Figure 46. Population, Economic Growth, Energy Consumption, and Carbon Emissions

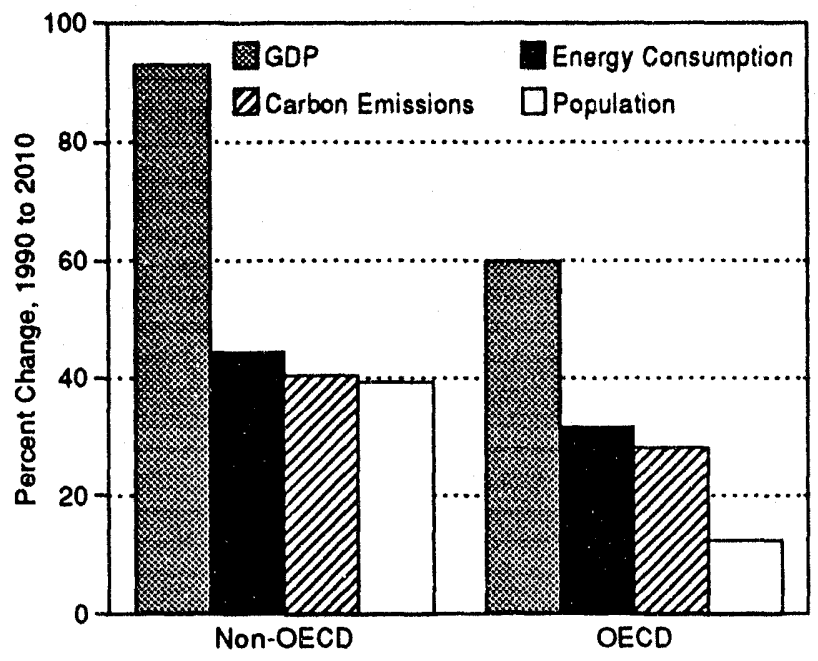

Sources: Derived from Tables 11 and A1, population data from United Nations, The Sex and Age Distribution of the World Populations: The 1992 Revision (New York, 1993), and GDP data from the WEFA Group, World Economic Service and World Economic Service Historical (June 1992) and World Economic Outlook (February and July 1993).

\section{Figure 47. Economic Development and National Energy Use Patterns, 2010}

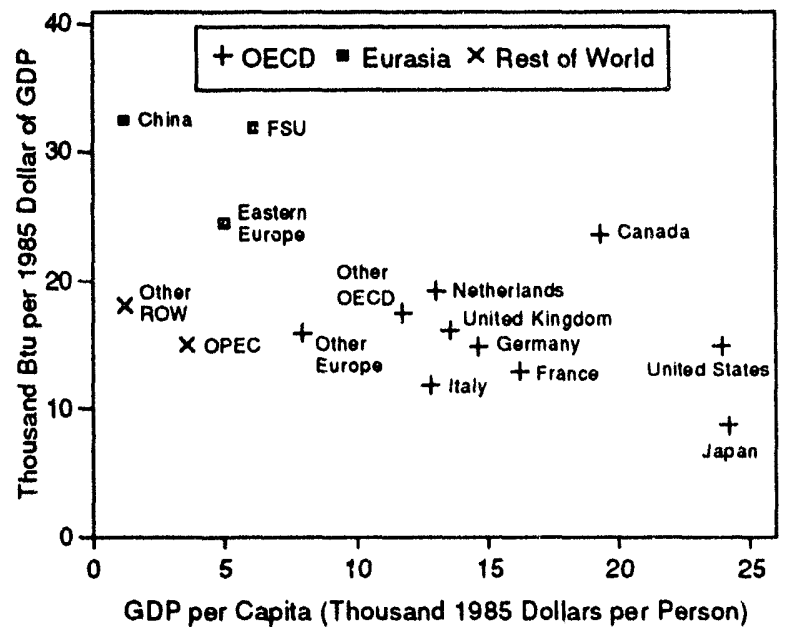

Sources: Derived from Table A2, population data from United Nations, The Sex and Age Distribution of the World Populations: The 1992 Revision (Now York, 1993), and GDP data from the WEFA Group, World Economic Service and World Economic Service Historical (June 1992) and World Economic Outlook (February and July 1993).

\section{Recent Status}

The Framework Convention on Climate Change was adopted in May 1992 by the United Nations Intergovernmental Negotiating Committee (INC) as an outgrowth of international discussions about global climate change [27, p. 11]. If national governments wish to take on the objectives of this conference, the objectives can be achieved either through international agreement or through taxes on the carbon content of fuels. Either approach would affect both the level and composition of energy consumption in any country employing it.

Any set of policy responses that might evolve could affect relationships between developed and developing countries. Actions taken by the OECD countries alone would be less effective than measures taken by all countries responsible for the major share of emissions. The latter course would certainly require the cooperation of the FSU and China, which together contributed approximately 25 percent to world carbon emissions in 1992 (Table 11). According to the International Energy Agency (IEA), a major challenge for participants in the INC process is to devise strategies acceptable to all participating countries, given the many different environmental and economic priorities involved. For example, a reduction in carbon dioxide emissions in developing countries could be difficult because economic development objectives in these countries imply increases in energy consumption. One strategy being considered is for the developed countries to provide assistance to capital-constrained countries in the interest of achieving global objectives that can benefit all [31, p. 30].

An added policy complexity arises from scientific uncertainty about the seriousness of the global climate change itself, including uncertainty about its economic and social consequences. It cannot be overlooked that greenhouse gas emissions resulting from human activities come from a wide range of economic activities that may be substantially curtailed only at large cost [5, p. 6].

The United Nations Conference on the Environment and Development (UNCED), held June 3-14, 1992, in Rio de Janeiro, set forth three objectives: the stabilization and reduction of greenhouse gas emissions, the financing of the incremental costs imposed by the Convention on developing countries, and the facilitation of technology transfer between countries.

Possibly the most important outcome of the Rio Convention was the agreement by the developed countries to adopt national policies with the objective of return- 
Table 13. Carbon Emissions from Natural Gas, 1990-2010

(Million Metric Tons)

\begin{tabular}{|c|c|c|c|c|c|c|c|c|c|c|c|}
\hline \multirow[b]{3}{*}{ Region/Country } & \multirow{2}{*}{\multicolumn{2}{|c|}{ History }} & \multicolumn{9}{|c|}{ Projections } \\
\hline & & & \multicolumn{3}{|c|}{2000} & \multicolumn{3}{|c|}{2005} & \multicolumn{3}{|c|}{2010} \\
\hline & 1990 & 1992 & $\begin{array}{l}\text { Base } \\
\text { Caso }\end{array}$ & $\begin{array}{c}\text { Sonsit } \\
\text { Ran }\end{array}$ & ivity & $\begin{array}{l}\text { Base } \\
\text { Case }\end{array}$ & $\begin{array}{l}\text { Sonsit } \\
\text { Ran }\end{array}$ & ivity & $\begin{array}{l}\text { Base } \\
\text { Case }\end{array}$ & $\begin{array}{r}\text { Sonsit } \\
\text { Ran }\end{array}$ & $\begin{array}{l}\text { ivity } \\
\text { ge }\end{array}$ \\
\hline \multicolumn{12}{|l|}{ OECD } \\
\hline United States & 274 & 285 & 324 & 316 & 334 & 348 & 331 & 362 & 356 & 341 & 372 \\
\hline Canada .... & 35 & 38 & 42 & 39 & 45 & 44 & 40 & 49 & 46 & 41 & 52 \\
\hline Japan. & 29 & 30 & 39 & 25 & 54 & 43 & 25 & 62 & 53 & 28 & 81 \\
\hline OECD Europe & 140 & 156 & 210 & 174 & 249 & 251 & 203 & 302 & 296 & 238 & 360 \\
\hline United Kingdom & 31 & 32 & 55 & 39 & 72 & 65 & 42 & 89 & 76 & 49 & 107 \\
\hline France $\ldots \ldots \ldots \ldots \ldots \ldots$ & 15 & 19 & 24 & 10 & 39 & 31 & 10 & 53 & 40 & 12 & 69 \\
\hline$\ldots \ldots \ldots \ldots \ldots$ & 29 & 35 & 51 & 25 & 79 & 58 & 27 & 92 & 66 & 30 & 106 \\
\hline Italy $\ldots \ldots \ldots \ldots \ldots \ldots$ & 25 & 25 & 28 & 23 & 33 & 32 & 24 & 41 & 36 & 25 & 48 \\
\hline Netherlands & 19 & 22 & 24 & 21 & 26 & 25 & 21 & 29 & 25 & 21 & 29 \\
\hline Other Europe & 20 & 23 & 28 & 19 & 36 & 40 & 25 & 54 & 52 & 32 & 73 \\
\hline Other OECD . . & 8 & 9 & 11 & 9 & 13 & 12 & 9 & 15 & 12 & 9 & 16 \\
\hline Total OECD $\ldots \ldots \ldots \ldots \ldots$ & 486 & 518 & 626 & 586 & 669 & 698 & 643 & 755 & 764 & 698 & 836 \\
\hline \multicolumn{12}{|l|}{ Eurasia } \\
\hline China & 8 & 8 & 14 & 11 & 17 & 17 & 13 & 22 & 20 & 14 & 27 \\
\hline Former Soviet Union & 338 & 327 & 338 & 321 & 357 & 391 & 340 & 442 & 445 & 356 & 542 \\
\hline Eastern Europe $\ldots \ldots \ldots \ldots$ & 49 & 39 & 50 & 40 & 61 & 57 & 39 & 77 & 65 & 36 & 95 \\
\hline Total Eurasia . ........... & 395 & 373 & 403 & 382 & 424 & 465 & 410 & 520 & 530 & 436 & 632 \\
\hline \multicolumn{12}{|l|}{ Rest of World (ROW) } \\
\hline Middle East & 55 & 60 & 73 & 61 & 85 & 84 & 58 & 112 & 95 & 66 & 128 \\
\hline Africa $\ldots \ldots \ldots \ldots$ & 21 & 24 & 26 & 21 & 30 & 30 & 20 & 40 & 34 & 24 & 46 \\
\hline Asia . & 36 & 45 & 79 & 66 & 92 & 111 & 76 & 149 & 146 & 102 & 196 \\
\hline Latin America . & 46 & 47 & 51 & 43 & 60 & 62 & 42 & 82 & 73 & 51 & 99 \\
\hline Total ROW $\ldots \ldots \ldots \ldots$ & 157 & 175 & 228 & 190 & 266 & 287 & 197 & 383 & 349 & 243 & 469 \\
\hline World Total $\ldots \ldots \ldots \ldots \ldots \ldots$ & 1,039 & 1,067 & 1,257 & 1,199 & 1,317 & 1,449 & 1,333 & 1,571 & 1,643 & 1,487 & 1,816 \\
\hline
\end{tabular}

$O E C D=$ Organization for Economic Cooperation and Development.

Sources: The U.S. numbers were taken from Energy Information Administration (EIA), Emissions of Greenhouse Gases in the United States 1985-1990, DOE/EIA-0573, Table 7; and Annual Energy Outlook 1994, DOE/EIA-0383(94), Tables A17, D17, and E17. History-Derived from EIA, International Energy Annual 1992, DOE/EIA-021(92) (1994), and carbon coefficients in Emissions of Greenhouse Gases in the United States 1985-1990, DOE/EIA-0573, Table 11, p. 15. Projectione-EIA, World Energy Projection System, 1994.

ing their anthropogenic emissions of carbon dioxide and other greenhouse gases to 1990 levels by the end of this decade [27, pp. 13-14]. Because these policies are not yet in place, however, projections throughout this report reflect current trends-according to which total carbon emissions would rise by more than one-third between 1990 and 2010.

At the same time developing countries are endeavoring to stabilize carbon emissions, some national governments are examining the basic idea of using taxes to influence consumer behavior-and specifically to "inter- nalize" environmental costs that traditionally have been borne by society as a whole but not reflected in the prices consumers pay for energy. This includes the idea of carbon-based fuel taxes. Since 1990, Denmark, Finland, the Netherlands, Norway, and Sweden have adopted carbon taxes [27, p. 16].

The Danish government introduced a carbon tax on May 15, 1992. The tax is on private energy consumption and functions in combination with previously existing energy taxes, which will be reduced. The Parliament also decided that a large portion of the tax revenue 
Table 14. Carbon Emissions from Coal, 1990-2010 (Million Metric Tons)

\begin{tabular}{|c|c|c|c|c|c|c|c|c|c|c|c|}
\hline \multirow[b]{3}{*}{ Region/Country } & \multirow{2}{*}{\multicolumn{2}{|c|}{ History }} & \multicolumn{9}{|c|}{ Projections } \\
\hline & & & \multicolumn{3}{|c|}{2000} & \multicolumn{3}{|c|}{2005} & \multicolumn{3}{|c|}{2010} \\
\hline & 1990 & 1992 & $\begin{array}{l}\text { Baso } \\
\text { Case }\end{array}$ & \multicolumn{2}{|c|}{$\begin{array}{c}\text { Sonsltivity } \\
\text { Range }\end{array}$} & $\begin{array}{l}\text { Base } \\
\text { Case }\end{array}$ & \multicolumn{2}{|c|}{$\begin{array}{c}\text { Sensitivity } \\
\text { Range }\end{array}$} & $\begin{array}{l}\text { Base } \\
\text { Case }\end{array}$ & \multicolumn{2}{|c|}{$\begin{array}{c}\text { Sonsitivity } \\
\text { Range }\end{array}$} \\
\hline \multicolumn{12}{|l|}{ OECD } \\
\hline United States & 480 & 481 & 514 & 503 & 523 & 531 & 524 & 545 & 580 & 549 & \\
\hline Canada . & 28 & 32 & 43 & 34 & 50 & 46 & 37 & 55 & 47 & 38 & 5 \\
\hline Japan. & 74 & 69 & 82 & 67 & 109 & 94 & 54 & 136 & 99 & 56 & 14. \\
\hline OECD Europe & 322 & 326 & 335 & 325 & 345 & 348 & 331 & 367 & 360 & 338 & 38 \\
\hline United Kingdom . & 61 & 70 & 69 & 69 & 70 & 68 & 66 & 70 & 68 & 66 & \\
\hline$\ldots \ldots \ldots \ldots \ldots$ & 23 & 22 & 20 & 17 & 22 & 18 & 13 & 23 & 15 & 9 & 2 \\
\hline$\ldots \ldots \ldots \ldots \ldots$ & 127 & 103 & 109 & 104 & 115 & 117 & 106 & 130 & 123 & 108 & 140 \\
\hline$\ldots \ldots \ldots$ & 13 & 13 & 15 & 9 & 20 & 15 & 9 & 21 & 16 & 10 & 2. \\
\hline Netherlands & 10 & 8 & 8 & 7 & 9 & 9 & 8 & 10 & 9 & 8 & 10 \\
\hline Other Europe & 88 & 110 & 114 & 107 & 120 & 122 & 110 & 132 & 129 & 115 & 14 \\
\hline Other OECD . . & 43 & 46 & 48 & 46 & 50 & 49 & 45 & 53 & 50 & 45 & 5 \\
\hline Total OECD $\ldots \ldots \ldots \ldots \ldots$ & 848 & 954 & 1,022 & 1,000 & 1,049 & 1,068 & 1,026 & 1,112 & 1,136 & 1,082 & 1,19 \\
\hline \multicolumn{12}{|l|}{ Eurasia } \\
\hline China ... & 542 & 558 & 756 & 671 & 846 & 869 & 729 & 1,026 & 978 & 780 & 1,207 \\
\hline Former Soviet Union & 325 & 262 & 271 & 256 & 286 & 275 & 258 & 293 & 279 & 259 & 300 \\
\hline Eastern Europe & 204 & 150 & 166 & 158 & 170 & 163 & 158 & 170 & 159 & 153 & 165 \\
\hline Total Eurasia & 1,072 & 870 & 1,192 & 1,113 & 1,276 & 1,307 & 1,177 & 1,452 & 1,416 & 1,232 & 1,63 \\
\hline \multicolumn{12}{|l|}{ Reat of World (ROW) } \\
\hline Middie East . . . . . . & 4 & 5 & 5 & 5 & 6 & 6 & 5 & 8 & 7 & 6 & \\
\hline Africa $\ldots \ldots \ldots \ldots$ & 85 & 99 & 103 & 91 & 115 & 106 & 88 & 126 & 110 & 87 & 137 \\
\hline Asia $\ldots \ldots \ldots \ldots$ & 213 & 221 & 259 & 228 & 289 & 291 & 241 & 345 & 324 & 253 & 402 \\
\hline Latin America .. & 22 & 25 & 33 & 29 & 37 & 41 & 34 & 48 & 48 & 37 & 55 \\
\hline Total ROW $\ldots \ldots \ldots \ldots \ldots$ & 323 & 350 & 399 & 352 & 446 & 445 & 368 & 526 & 489 & 383 & 60) \\
\hline World Total $\ldots \ldots \ldots \ldots \ldots \ldots$ & 2,343 & 2,274 & 2,614 & 2,517 & 2,717 & 2,820 & 2,660 & 2,997 & 3,041 & 2,816 & 3,299 \\
\hline
\end{tabular}

OECD = Organization for Economic Cooperation and Development.

Sources: The U.S. numbers were taken from Energy Information Administration (EIA), Emissions of Greenhouse Gases in the United States 1985-1990, DOE/EIA-0573, Table 7; and Annual Energy Outlook 1994, DOE/EIA-0383(94), Tables A17, D17, and E17. History-Derived from ElA, International Energy Annual 1992, DOE/ElA-021(92) (1994), and carbon coefficients in Emissions of Greenhouse Gases in the United States 1985-1990, DOE/EIA-0573, Table 11, P. 15. Projections-EIA, World Energy Projection System, 1994.

generated would be used for specified energy efficiency subsidies, such as the promotion of district heating and combined heat and power plants and energy conservation in the commercial and industrial sectors [27, p. 55].

The Finnish government imposed a carbon tax in 1990 that was estimated to raise the price of gasoline by 6 percent, the price of natural gas by 2 percent, and the price of coal by 8 percent. In the 1991 budget, this carbon tax was estimated to increase gasoline prices by 7 percent and to increase the price of other fuels by about 5 percent over 1990 levels [27, p. 58].
In the Netherlands, a tax on fuels related to their carbon emissions went into effect in February 1990. In 1992, this tax was reformed so that its basis was $\mathbf{5 0}$ percent carbon emissions and 50 percent energy content [27, p. 85].

In January 1991 the Norwegian government introduced a carbon tax on the domestic use of gasoline and the combustion of natural gas offshore. The exemptions to the tax were travel and transport by air and international and domestic sea transport. The carbon tax was redefined in July 1992 to include coal. However, coal 


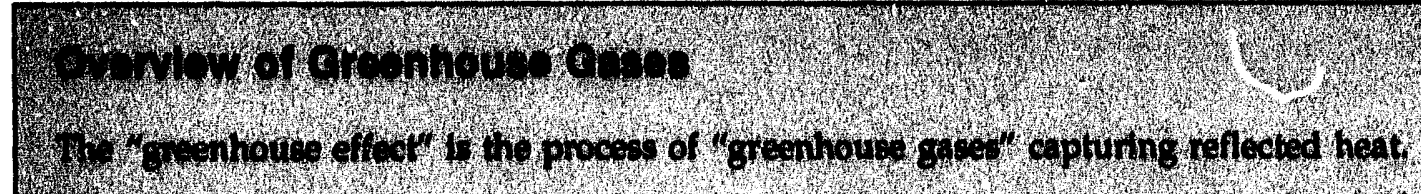

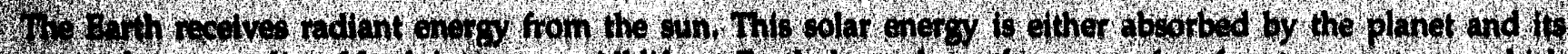

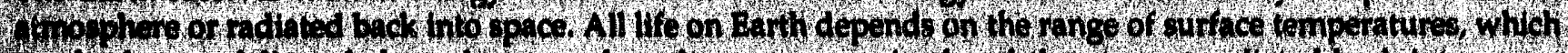

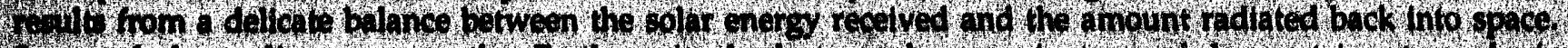

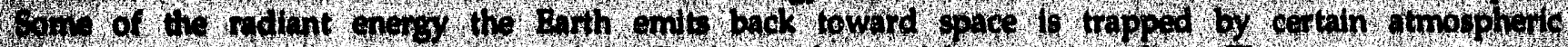

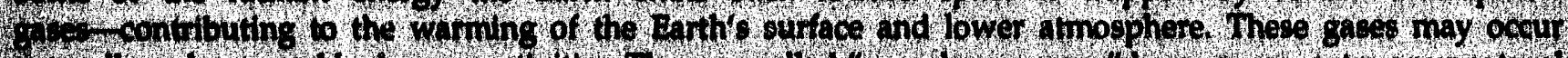

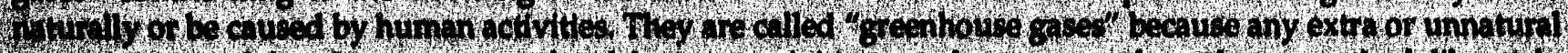

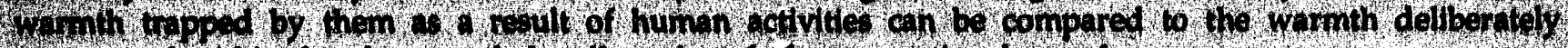

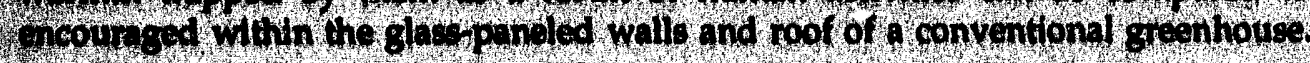

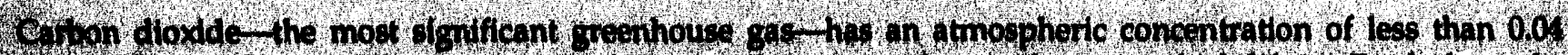

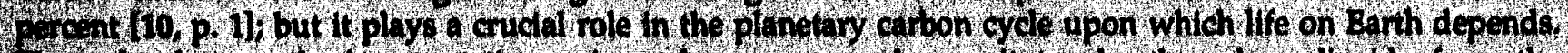

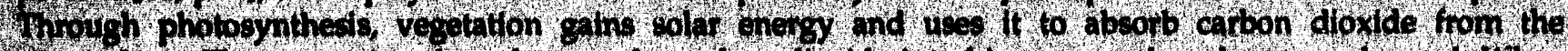
1. 4- Hon decays, carbon is relessed bick into the atmosphere or Lack to the soll. The ocean also absorbs and 16.6. carton.

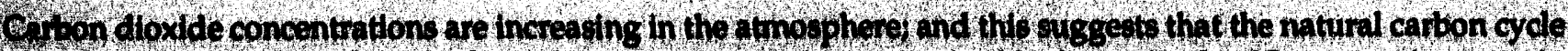

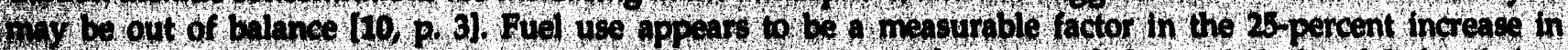

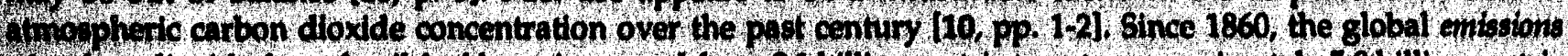
of ctwon dioxide from foseil fuel have linareased from 0.1 biliton metric tons to approximately 5.9 billion metric tons in 1988 [10, p. 4$)$

Hore are some relevant attributes of other greentrouse gases:

Wole vepor is a primary absorber of infrared radiation. It has many natural sources and sinks, such as extporation from the oceans and precipitation [10, P. 8].

Anthropogenic methane is an unintended byproduct of the production and combustion of fossil fuels, as well as the decompositton of human and animal wastes and of organic matter in rice paddles. Estimates of anthropogenic methane are very uncertain, because emissions of this gas are calculated indirectly from small volumes of experimental data [10, p. 25]. However, methane absorbs heat especlally well, and a single molecule can have 20 times as much effect on climate as one molecule of carbon dioxide [10, p. 1].

Anthropogenie nitrous oxide emissions come from the use of ammonium nitrate and organic fertilizers, from the burning of fossil fuels, and from soil emissions released in agricultural management. Nitrous oxide is a stable gas with a long atmospheric lifetime, and it has a global warming potential range from 170 to 260 times the effect of carbon dioxide [10, p. 43].

Hilocarbons (of which chlorofluorocarbons-CFCs-are the most common) are used for such purposes as refrigeration, solvent cleaning, sterilization, and insulation. Besides their operation as greenhouse gases in absorbing infrared radiation, CFCs produce a cooling effect by destroying ozone in the stratosphere (the upper atmosphere) and closer to the Earth's surface. Thus, their impact on the global climate is complicated, and sclentists are unsure whether the net effect of atmospheric CFCs is waming or cooling [10, p. 8).

used as an input to industrial processes was exempted [27, p. 92].

In Sweden, a carbon tax was introduced on January 1, 1991, applying to all fossil fuels except those used for electricity production. The tax was lowered for commercial greenhouses and energy-intensive greenhouses. In June 1992 the tax was increased for the residential and commercial sectors and decreased for the industrial sector. Under this carbon tax, biofuels are not taxed [27, pp. 102-103].

According to the IEA, carbon taxes should be viewed in the context of other large taxes on energy sources, which may include excise taxes and value-added taxes. These may be imposed for fiscal or other reasons that have no direct relationship to the environmental effects of any given fuel, in which case their net price effect is 
less likely to influence consumption behavior significantly and selectively. In addition, there are many exemptions from the new carbon taxes in each country, except in the Netherlands. For example, Sweden's carbon tax of approximately $\$ 41$ per metric ton of carbon dioxide was introduced along with reductions in other taxes. Because of the exemptions, the taxes are not strictly based on the carbon content of the fuels [30, p. 28].

In return for the commitments signed by the developing countries at the Rio Convention, developed countries agreed to provide them with greater technological cooperation, as well as funding for the full incremental costs of all measures they needed to take and for the adaptation assistance especially vulnerable countries might require. The Global Environmental Facility (GEF) provides the financial mechanism for this operation. On February 28, 1992, the United States announced that it would give $\$ 25$ million for the analysis of national climate change strategies and $\$ 50$ million more to the GEF [27, pp. 17-18].

The IEA and the OECD have also set up the IEA/ OECD Technology Information Exchange (TIE) to help countries gather information on technologies relevant to climate change policies. TIE is establishing a directory of technology information sources and expertise in regard to the control and stabilization of greenhouse gas emissions. These information sources and expertise should be compatible with the particular target customer group. In order to improve the exchange of information among participating countries, TIE will create a network connecting national and multilateral information centers that specialize in the control and stabilization of greenhouse gas emissions [27, p. 19].

According to the World Bank, total world energy subsidies are approximately $\$ 210$ billion. The FSU accounts for over two-thirds of the total world subsidies, about $\$ 145$ billion. Iran has the second highest level of energy subsidies, about $\$ 11$ billion, and China has the third highest level of subsidies, about $\$ 8$ billion. The World Bank estimates that, assuming no change in world prices of fossil fuels, the removal of total world subsidies would result in a 7-percent reduction in world global carbon emissions from fossil fuel consumption by 2010, of which 56 percent are from coal, 30 percent from gas, and 14 percent from petroleum products. Potential reductions in national carbon emissions are estimated to be larger than 20 percent in the FSU, Poland, the Czech Republic and Slovakia, Iran, Romania, and Venezuela [33, p. 18-20]. 


\title{
Comparison of International Energy Projections
}

\author{
Outlook alternatives illustrate the uncertainties, particularly for \\ energy prospects in the developing countries of the world.
}

Projections of world energy markets involve considerable uncertainty. A major reason for this uncertainty is that the course of political events around the world are unpredictable. In the past, for example, hostilities in the Middle East region caused major and unexpected disruptions in world oil markets. Much less influential but still adding uncertainty to world energy prospects are such events as decisions by the Organization of Petroleum Exporting Countries (OPEC) about oil production and prices; decisions by members of the Organization for Economic Cooperation and Development (OECD) about energy security and about financial and technical assistance to the developing world; and decisions in the former Soviet Union (FSU), Eastern Europe, and China about the nature and pace of political and economic reforms.

There is also uncertainty concerning prospects for the key determinants of energy supply and demand. These include the rate of economic growth and actions concerning energy efficiency, cons.rvation, and the environment. Projections of world energy markets by energy analysts will differ depending on the assumptions made about these and other factors. Additional variation can occur because of differences in availability and reliability of data, definitions, conversions factors, and timing of the analysis. The comparisons here sketch out some of the differences between projections presented in the International Energy Outlook 1994 (IEO94) and other widely used energy projections.

\section{World Energy Consumption}

The IEO94 Base Case projections of world energy consumption by energy type are compared with those in IEO93 and those made by the International Energy Agency (IEA) in Paris, Petroleum Economics Ltd. (PEL) in London, and Petroleum Industry Research Associates (PIRA) in New York (Table 15). Two adjustments were made to the various projections to put them on a comparable basis. First, the IEO94 and IEO93 projec- tions, in quadrillion Btu, and the IEA prujections, in million metric tons oil equivalent, were converted to million barrels per day oil equivalent. Next, the IEA values for "other" energy (predominantly hydroelectricity) were adjusted to account for the fact that the IEA uses a different convention for electricity plant efficiency than do other analysts, including the Energy Information Administration (EIA). The IEA assumes 100 percent efficiency for a hydroelectric plant (one unit of electricity output is associated with one unit of primary energy input) and 10 percent efficiency for geothermal. In contrast, the EIA assumes a fossil-fuel efficiency rate of 33 percent for hydroelectric power generation (one unit of electricity output is associated with 3 units of primary energy inputs) and a rate of 16 percent for geothermal.

An additional difference among these studies results from the energy accounting methods used. Specifically, the IEA coal amount also includes OECD use of energy from wood and other solid fuels. In IEO94 and IEO93, "other" includes United States use of energy from wood, wind, solar, and other biofuels.

Given these differences in energy accounts, the projections for total energy consumption through $\mathbf{2 0 0 0}$ are quite similar in the five studies (Table 15). For example, growth rates in total energy consumption between 1990 and 2000 fall within a range of 1.5 to 1.7 percent per year (Table 16). Energy consumption for 2000 is slightly lower in IEO94 than it was in IEO93. The difference is because of reduced expectations over this period for the FSU and Eastern Europe (Table 17).

Projections for total energy and individual energy types differ much more among the five studies for the period beyond 2000. In particular, the IEA projects considerably higher growth for all energy sources between 2000 and 2010 than do the other studies. PIRA also projects relatively fast growth between 2000 and 2005, particularly for natural gas and coal (Table 16). 
The differences in world energy consumption among the studies results primarily from differences in prospects for the non-OECD regions of the world (Table 16). For example, average annual growth rates for the OECD between 1990 and 2010 range from 1.1 percent per year in the PEL study to 1.4 percent per year in IEO94. In contrast, rates for the non-OECD regions taken together range from 1.9 percent in IEO94 to 2.6 percent per year in the IEA study. Rates for the Rest of World (ROW)-non-OECD less Eurasia-vary from 2.7 percent per year in IEO94 to 4.4 percent per year in the IEA study.
The regional energy projections difior primarily because of different assumptions about economic growth and about changes in the energy intensity of economic activity. Projections of economic growth for the OECD are similar in all studies, ranging from 2.2 to 2.4 percent per year between 1990 and 2010 (Table 18). However, economic growth rates for the world as a whole range from 2.6 to 3.6 percent per year over this time interval. Much of the difference in the world rate results from assumed growth rates for the ROW countries and China. Higher rates of growth in economic activity in the IEA and PIRA studies result in higher rates of growth in energy consumption.

Table 15. Comparison of Energy Consumption by Type, 1990-2010 (Million Barrels per Day Oil Equivalent)

\begin{tabular}{|c|c|c|c|c|c|c|}
\hline Source/Year & Oil & Gas & $\mathrm{Coal}^{\mathrm{a}}$ & Nuclear & Otherb & Total \\
\hline \multicolumn{7}{|l|}{ IEO84 } \\
\hline $1990 \ldots \ldots \ldots$ & 66.2 & 35.2 & 44.9 & 9.9 & 12.8 & 169.0 \\
\hline $2000 \ldots \ldots \ldots$ & 77.4 & 42.4 & 50.0 & 11.6 & 16.1 & 197.5 \\
\hline $2005 \ldots \ldots \ldots$ & 82.4 & 48.9 & 53.9 & 12.0 & 18.0 & 215.3 \\
\hline $2010 \ldots \ldots \ldots$ & 86.5 & 55.4 & 58.2 & 12.0 & 20.6 & 232.7 \\
\hline \multicolumn{7}{|l|}{ IEO93 } \\
\hline $1990 \ldots \ldots \ldots$ & 66.2 & 35.4 & 45.0 & 9.9 & 12.9 & 169.4 \\
\hline $2000 \ldots \ldots \ldots$ & 76.5 & 44.0 & 51.5 & 12.5 & 15.9 & 200.4 \\
\hline $2005 \ldots \ldots \ldots$ & 81.6 & 49.5 & 54.5 & 13.6 & 17.5 & 216.7 \\
\hline $2010 \ldots \ldots \ldots$ & 85.9 & 54.7 & 58.0 & 14.6 & 19.6 & 232.8 \\
\hline \multicolumn{7}{|l|}{ IEA } \\
\hline $1990 \ldots \ldots \ldots \ldots$ & 66.3 & 36.3 & 49.5 & 11.3 & 12.5 & 176.0 \\
\hline $2000 \ldots \ldots \ldots$ & 77.1 & 42.8 & 57.3 & 13.2 & 17.8 & 208.1 \\
\hline $2005 \ldots \ldots \ldots$ & - & -- & $\cdots$ & -. & 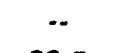 & $-\cdot$ \\
\hline $2010 \ldots \ldots \ldots$ & 92.0 & 60.3 & 71.1 & 14.9 & 23.5 & 261.9 \\
\hline \multicolumn{7}{|l|}{ PEL } \\
\hline $1990 \ldots \ldots \ldots$ & 66.4 & 35.4 & 46.7 & 9.9 & 11.1 & 169.5 \\
\hline $2000 \ldots \ldots \ldots$ & 74.6 & 45.2 & 51.3 & 11.7 & 14.7 & 197.5 \\
\hline $2005 \ldots \ldots \ldots$ & 80.2 & 50.4 & 54.9 & 12.3 & 16.7 & 214.5 \\
\hline $2010 \ldots \ldots \ldots$ & 85.9 & 56.1 & 57.4 & 12.6 & 18.4 & 230.4 \\
\hline \multicolumn{7}{|l|}{ PIRA } \\
\hline $1990 \ldots \ldots \ldots$ & 66.3 & 35.3 & 46.2 & 10.4 & 10.5 & 168.7 \\
\hline $2000 \ldots \ldots \ldots$ & 78.0 & 40.7 & 53.5 & 12.3 & 13.8 & 198.2 \\
\hline $2005 \ldots \ldots \ldots$ & 86.2 & 48.7 & 62.8 & 12.4 & 15.5 & 225.6 \\
\hline $2010 \ldots \ldots \ldots$ & -. & $\cdots$ & - & -. & $-\cdot$ & -. \\
\hline
\end{tabular}

The IEA and PEL values include small amounts of energy from use of wood and other solid fuels in selected regions.

"Other" energy consists primarily of hydroelectricity and geothermal. The IEO94 amount also includes U.S. consumption of energy from solar, wind, wood, and other biofuels.

Sources: IEO94: International Energy Outlook 1994, DOE/EIA-0484(94). IEO93: International Energy Outlook 1993, DOE/EIA-0484(93). IEA: International Energy Agency, Paris, World Energy Outlook, 1993. PEL: Petroleum Economics Ltd., London, World-Long Term Oil and Energy Outlook to 2010, December 1993. PIRA: Petroleum Industry Research Associates Inc., Annual Retainer Client Seminar-World and U.S. Oil, October 1993. 
Also contributing to higher rates of growth in energy consumption in the IEA study is the assumption about the energy intensity of economic activity - energy consumption divided by a measure of economic activity, usually gross domestic product (GDP). The IEA assumes that the energy intensity of economic activity will decline (improve) at a rate of 0.7 percent per year between 1990 and 2010. The IEO94 and the PEL study assume that this rate will be about 1.1 percent per year over this period. The PIRA study assumes an even greater improvement in energy intensity, about 1.6 percent per year between 1990 and 2005. However, the PIRA study couples this rate of improvement with the highest rate for world economic growth, 3.6 percent per year compared to 2.7 percent per year in the IEO94.

\section{World Oll Market}

Additional comparisons were made for projections of the world oil market (Table 19). Projections by DRI/ MCGraw-Hill (DRI) and NatWest Washington Analysis (NWA), available for oil but not for total energy, are added to the oil market comparison. IEO94 has a slightly more optimistic outlook for oil than did IEO93 in that the world consumes more oil over the projection period in IEO94 and, at the same time, pays less, except in terms of carbon emissions-about 0.3 percent higher by 2010 in IEO94. The gain in oil consumption is made possible by OPEC, which produces more oil at the lower price. In contrast to OPEC, production for Eurasia is less in IEO94 than in IEO93.

Table 16. Comparison of Energy Consumption Growth Rates by Type, 1990-2010 (Percent per Year)

\begin{tabular}{|c|c|c|c|c|c|c|}
\hline Source/Yoar & OII & Gas & Coal & Nuclear & Other & Total \\
\hline \multicolumn{7}{|l|}{ IEO94 } \\
\hline $1990-2000 \ldots \ldots \ldots$ & 1.6 & 1.9 & 1.1 & 1.6 & 2.3 & 1.6 \\
\hline $2000-2010 \ldots \ldots \ldots$ & 1.1 & 2.7 & 1.5 & 0.4 & 2.5 & 1.7 \\
\hline $1990-2005 \ldots \ldots \ldots$ & 1.5 & 2.2 & 1.2 & 1.3 & 2.3 & 1.6 \\
\hline $1990-2010 \ldots \ldots \ldots$ & 1.3 & 2.3 & 1.3 & 1.0 & 2.4 & 1.6 \\
\hline \multicolumn{7}{|l|}{ IEO93 } \\
\hline $1990-2000 \ldots \ldots \ldots$ & 1.5 & 2.2 & 1.4 & 2.3 & 2.2 & 1.7 \\
\hline $2000-2010 \ldots \ldots \ldots$ & 1.2 & 2.2 & 1.2 & 1.6 & 2.1 & 1.5 \\
\hline $1990-2005 \ldots \ldots \ldots$ & 1.4 & 2.3 & 1.3 & 2.1 & 2.1 & 1.7 \\
\hline $1990-2010 \ldots \ldots \ldots$ & 1.3 & 2.2 & 1.3 & 1.9 & 2.1 & 1.6 \\
\hline \multicolumn{7}{|l|}{ IEA } \\
\hline $1990-2000 \ldots \ldots \ldots$ & 1.5 & 1.6 & 1.5 & 1.5 & 3.6 & 1.7 \\
\hline $2000-2010 \ldots \ldots \ldots$ & 1.8 & 3.5 & 2.2 & 1.3 & 2.8 & 2.3 \\
\hline $1990-2005 \ldots \ldots \ldots$ & $\cdots$ & -- & $\cdot \cdot$ & $\cdot \cdot$ & $\cdot \cdot$ & -- \\
\hline $1990-2010 \ldots \ldots \ldots$ & 1.7 & 2.6 & 1.8 & 1.4 & 3.2 & 2.0 \\
\hline \multicolumn{7}{|l|}{ PEL } \\
\hline $1990-2000 \ldots \ldots \ldots$ & 1.2 & 2.5 & 0.9 & 1.7 & 2.8 & 1.5 \\
\hline $2000-2010 \ldots \ldots \ldots$ & 1.4 & 2.2 & 1.1 & 0.7 & 2.3 & 1.6 \\
\hline $1990-2005 \ldots \ldots \ldots$ & 1.3 & 2.4 & 1.1 & 1.5 & 2.8 & 1.6 \\
\hline $1990-2010 \ldots \ldots \ldots$ & 1.3 & 2.3 & 1.0 & 1.2 & 2.6 & 1.5 \\
\hline \multicolumn{7}{|l|}{ PIRA } \\
\hline $1990-2000 \ldots \ldots \ldots$ & 1.6 & 1.4 & 1.5 & 1.7 & 2.8 & 1.6 \\
\hline $2000-2005 \ldots \ldots \ldots$ & 2.0 & 3.7 & 3.3 & 0.2 & 2.4 & 2.6 \\
\hline $1990-2005 \ldots \ldots \ldots$ & 1.8 & 2.2 & 2.1 & 1.2 & 2.6 & 2.0 \\
\hline 1990-2010. & - &.- & -- & $\ddot{-}$ & $\cdots$ & $\cdots$ \\
\hline
\end{tabular}

Sources: Derived from: IEO94: International Energy Outlook 1994, DOE/EIA-0484(94). IEO93: International Energy Outlook 1993, DOE/EIA-0484(93). IEA: International Energy Agency, Paris, World Energy Outlook, 1993. PEL: Petroleum Economics Ltd., London, World-Long Term Oil and Energy Outlook to 2010, December 1993. PIRA: Petroleum Industry Research Associates Inc., Annual Retainer Client Seminar-World and U.S. Oil, October 1993. 
Table 17. Average Annual Growth Rates in Energy Consumptlon by Reglon, 1990-2010 (Percent per Year)

\begin{tabular}{|c|c|c|c|c|}
\hline Source/Roglon & $1980-2000$ & $2000-2010$ & 1990-2005 & $1990-2010$ \\
\hline \multicolumn{5}{|l|}{ IEO94 } \\
\hline OECD $\ldots \ldots \ldots \ldots$ & 1.7 & 1.1 & 1.5 & 1.4 \\
\hline Non-OECD $\ldots . . .$. & 1.5 & 2.2 & 1.8 & 1.9 \\
\hline Eurasia .......... & 0.4 & 2.2 & 1.0 & 1.3 \\
\hline FSU $\ldots \ldots \ldots \ldots$ & -1.1 & 1.9 & -0.1 & 0.4 \\
\hline EE $\ldots \ldots \ldots \ldots$ & -1.2 & 1.2 & -0.4 & 0.0 \\
\hline China...$\ldots \ldots$ & 3.6 & 2.9 & 3.4 & 3.2 \\
\hline ROW $\ldots \ldots \ldots \ldots$ & 3.0 & 2.3 & 2.8 & 2.7 \\
\hline World ............ & 1.6 & 1.7 & 1.6 & 1.6 \\
\hline \multicolumn{5}{|l|}{ IEO93 } \\
\hline OECD $\ldots \ldots \ldots \ldots$ & 1.6 & 1.0 & 1.4 & 1.3 \\
\hline Non-OECD ........ & 1.8 & 2.1 & 1.9 & 1.9 \\
\hline CPE's $\ldots \ldots \ldots \ldots$ & 1.2 & 2.0 & 1.5 & 1.6 \\
\hline FSU $\ldots \ldots \ldots \ldots$ & -0.2 & 1.9 & 0.5 & 0.9 \\
\hline EE/Other . . . . . . . & 0.1 & 1.0 & 0.4 & 0.5 \\
\hline China $\ldots \ldots \ldots \ldots$ & 4.1 & 2.5 & 3.6 & 3.3 \\
\hline Row $\ldots \ldots \ldots \ldots$ & 2.8 & 2.2 & 2.6 & 2.5 \\
\hline World ............ & 1.7 & 1.5 & 1.7 & 1.6 \\
\hline \multicolumn{5}{|l|}{ IEA } \\
\hline OECD $\ldots \ldots \ldots \ldots$ & 1.5 & 1.2 & -. & 1.3 \\
\hline NOn-OECD $\ldots \ldots \ldots$ & 1.8 & 3.4 & .. & 2.6 \\
\hline Eurasia .......... & -0.3 & 2.6 & -- & 1.2 \\
\hline FSU/EE $\ldots \ldots \ldots$ & -2.0 & 2.3 & .. & 0.2 \\
\hline China .......... & 3.3 & 3.1 & -. & 3.2 \\
\hline ROW $\ldots \ldots \ldots \ldots$ & 4.5 & 4.2 & .. & 4.4 \\
\hline World ........... & 1.6 & 2.3 & & 2.0 \\
\hline \multicolumn{5}{|l|}{ PEL } \\
\hline OECD $\ldots \ldots \ldots$ & 1.3 & 0.9 & 1.2 & 1.1 \\
\hline Non-OECD $\ldots \ldots \ldots$ & 1.8 & 2.2 & 2.0 & 2.0 \\
\hline Eurasia $\ldots \ldots \ldots \ldots$ & -0.2 & 1.3 & 0.3 & 0.6 \\
\hline FSU $\ldots \ldots \ldots \ldots$ & -2.5 & 0.2 & -1.6 & -1.1 \\
\hline EE $\ldots \ldots \ldots \ldots$ & -0.4 & 2.1 & 0.3 & 0.8 \\
\hline China $\ldots \ldots \ldots \ldots$ & 3.6 & 2.3 & 3.2 & 2.9 \\
\hline ROW $\ldots \ldots \ldots$ & 4.3 & 3.1 & 3.9 & 3.7 \\
\hline World ............ & 1.5 & 1.6 & 1.6 & 1.5 \\
\hline \multicolumn{5}{|l|}{ PIRA $^{a}$} \\
\hline OECD $\ldots \ldots \ldots \ldots$ & 1.4 & 1.1 & 1.3 & .* \\
\hline Non-OECD $\ldots \ldots \ldots$ & 1.9 & 4.1 & 2.6 & .. \\
\hline World ............. & 1.6 & 2.6 & 2.0 & \\
\hline
\end{tabular}

OECD = Organization for Economic Cooperation and Development. FSU = former Soviet Union. EE = Eastern Europe. ROW $=$ Rest of World. CPE's = former Centrally Planned Economies.

a Growth rates post 2000 are for the period 2000 to 2005.

Sources: Derived from: IEO94: International Energy Outlook 1994, DOE/EIA-0484(94). IEO93: International Energy Outlook 1993, DOE/EIA-0484(93). IEA: International Energy Agency, Paris, World Energy Outlook, 1993. PEL: Petroleum Economics Ltd., London, World-Long Term Oil and Energy Outlook to 2010, December 1993. PIRA: Petroleum Industry Research Associates Inc., Annual Retainer Client Seminar-World and U.S. Oil, October 1993. 
Again, the outstanding difference among the studies is the more rapid growth in oil consumption and production projected by the IEA. The IEA projects oil consumption growth to be particularly strong in the Rest of World (ROW) region and matches higher ROW consumption with higher ROW production (OPEC plus "Other" in Table 19). Greater production in the IEA study is achieved with the world oil price in 2010 at about the same level as that projected in IEO94. How. ever, IEA prices rise more rapidly before 2000 than they do in IEO94 to reflect rapid expansion in production capacity over this period.

World oil consumption and production levels projected for 2010 are similar in IEO94 and the DRI and PEL studies. However, PEL achieves the same general level of world consumption with oil prices declining in real terms, that is, rising less than the general rate of inflation. The PIRA study has prices remaining constant in real terms through 2005, at about $\$ 18$ per barrel. On the other hand, the IEO94 and DRI project similar price levels as does the IEA, but resulting consumption and production levels are considerably lower. The IEA assumes that production capacity will be developed more fully by OPEC and other developing countries than do the other studies. Increased capacity would be encouraged by prices that rise slightly faster than the rate of inflation over the projection period. This oil would be needed to help meet energy demands that result from higher rates of economic growth and a lower rate of change in the energy intensity of economic growth than those assumed in IEO94.

Table 18. Economic Growth Assumptions by Reglon for Selected Studies, 1990-2010 (Average Annual Rates)

\begin{tabular}{|c|c|c|c|c|}
\hline Region & IEO94 & IEA & PEL & PIRA $^{a}$ \\
\hline OECD $\ldots \ldots \ldots \ldots$ & 2.4 & 2.4 & 2.2 & 2.3 \\
\hline North America ${ }^{b} \ldots$... & 2.2 & 2.3 & 2.2 & 2.3 \\
\hline Europe ........... & 2.2 & 2.3 & 1.9 & 2.1 \\
\hline Pacific $^{b} \ldots \ldots \ldots$ & 3.1 & 2.9 & 2.9 & 3.0 \\
\hline Non-OECD . . . . . . . & 3.3 & -- & 4.0 & 4.9 \\
\hline Eurasia $\ldots . . . \ldots$ & 2.3 & .. & 3.6 & 4.3 \\
\hline China ........... & 7.0 & 7.6 & 5.9 & 7.8 \\
\hline FSU $\ldots \ldots \ldots \ldots$ & 0.5 & 1.1 & -0.2 & -. \\
\hline EE $\ldots \ldots \ldots \ldots$ & 1.1 & 2.2 & 1.2 & .. \\
\hline FSU/EE $\ldots \ldots \ldots$ & 0.7 & 1.4 & 0.2 & 0.7 \\
\hline Row $\ldots \ldots \ldots \ldots$ & 4.2 & -. & 4.1 & 4.0 \\
\hline ROW/China ....... & 4.7 & 5.1 & 4.3 & 5.5 \\
\hline$\ldots \ldots \ldots \ldots$ & 2.7 & 3.0 & 2.6 & 3.6 \\
\hline
\end{tabular}

arowth rates are for the period 1990-2005.

bPEL and PIRA growth rates for North America and Pacific include only those for the United States and Japan, respectively. $O E C D=$ Organization for Economic Cooperation and Development. FSU = former Soviet Union. EE = Eastern Europe. ROW $=$ Rest of World.

Sources: Derived from: IEO94: International Energy Outlook 1994, DOE/EIA-0484(94). IEA: International Energy Agency, Paris, World Energy Outlook, 1993. PEL: Petroleum Economics Ltd., London, World-Long Term Oil and Energy Outlook to 2010, December 1993. PIRA: Petroleum Industry Research Associates Inc., Annual Retainer Client Seminar-World and U.S. Oll, October 1993. 
Tablo 18. Comparison of World Oll Projections

(Million Barrels per Day)

\begin{tabular}{|c|c|c|c|c|c|c|c|c|c|}
\hline \multirow[b]{2}{*}{ Year/source } & \multicolumn{4}{|c|}{ Oll Consumption } & \multicolumn{4}{|c|}{ Oll Production } & \multirow[b]{2}{*}{ Pricot } \\
\hline & World & OECD & Eurasia & ROW & World" & OPEC & Eurasia & Other & \\
\hline \multicolumn{10}{|l|}{ Year 1902} \\
\hline IEO94 ....... & 66.7 & 38.8 & 10.4 & 17.6 & 67.1 & 26.4 & 12.0 & 28.7 & $\$ 18.20$ \\
\hline \multicolumn{10}{|l|}{ Year 2000} \\
\hline IEO94 . . . . . & 77.4 & 4.8 & 10.7 & 22.0 & $\mathbf{7 7 . 0}$ & 35.5 & 11.9 & 29.6 & 20.70 \\
\hline IEO93 $^{\circ} \ldots \ldots$ & 76.5 & 42.8 & 12.2 & 21.5 & 76.2 & 33.1 & 12.9 & 30.2 & 23.56 \\
\hline PEL $\ldots \ldots \ldots$ & 74.6 & 41.3 & 10.3 & 23.0 & 74.8 & 29.2 & 12.4 & 28.4 & 15.60 \\
\hline NWA $^{d} \ldots \ldots$ & 77.4 & 43.1 & 10.8 & 23.5 & 77.6 & 33.9 & 11.6 & 32.1 & .. \\
\hline DRI $\ldots \ldots \ldots$ & 75.5 & 42.4 & 11.8 & 21.3 & 75.5 & 33.6 & 12.1 & 28.1 & 20.94 \\
\hline $\mathrm{IEA}^{\circ}$. & 77.3 & 42.6 & 8.3 & 26.4 & 77.5 & 31.1 & 8.6 & 36.1 & 26.62 \\
\hline PIRA $^{d}$ & 78.0 & 42.4 & 12.6 & 23.0 & 78.1 & 34.5 & 11.6 & 32.0 & 17.94 \\
\hline \multicolumn{10}{|l|}{ Year 2010} \\
\hline IEO94. & 86.5 & 47.8 & 13.2 & 25.6 & 86.2 & 44.0 & 14.8 & 27.4 & 28.20 \\
\hline IEO93 $^{C}$ & 85.9 & 45.6 & 15.3 & 25.0 & 85.6 & 42.7 & 15.3 & 27.6 & 30.15 \\
\hline PEL $\ldots \ldots \ldots$ & 85.9 & 42.9 & 14.1 & 28.9 & 86.1 & 38.2 & 15.2 & 26.7 & 14.63 \\
\hline DRI $\ldots \ldots \ldots$ & 86.8 & 46.5 & 13.7 & 26.6 & 86.7 & 40.2 & 14.9 & 29.8 & 28.56 \\
\hline $\operatorname{IEA}^{\circ} \ldots \ldots \ldots$ & 92.5 & 45.2 & 10.3 & 37.0 & 92.8 & 45.4 & 10.6 & 34.9 & 29.25 \\
\hline
\end{tabular}

All world totals include natural gas liquids, condensate, and refinery gains even if not explicitly attributed to one of the world's regions.

b1992 dollars per barrel. PEL lists the price for Brent crude oil. PIRA lists the price for West Texas Intermediate crude oil.

'Eurasia includes amounts for Cambodia, Cubz, Laos, Mongolia, and North Korea. These countries along with Eurasia (China, the former Soviet Union, and Eastern Europe) were defined as the former Centrally Planned Economies in IEOg3.

dProduction for Eurasia includes only that from the former Soviet Union and China. Eastern Europe production is included in ROW.

"Eurasia includes only amounts for the former Soviet Union and Eastern Europe. China amounts are included in ROW. Production listed under OPEC consists of production from the Middle East and Venezuela.

OECD = Organization for Economic Cooperation and Development.

OPEC = Organization of Petroleum Exporting Countries.

ROW = Rost of World.

Sources: IEO94: International Energy Outlook 1994, DOE/EIA-0484(94), Tables 2 and 3. PEL: Petroleum Economics Lid., London, World--Long Term Oil and Energy Outlook to 2010, December 1993. NWA: NatWest Washington Analysis, Oil Market Update, September 22, 1993. DRI: DRI/McGraw-Hill, Energy Review, Fall-Winter 1993-94. IEA: International Energy Agency, Paris, World Energy Outlook, 1993. PIRA: Petroleum Industry Research Associates, Inc., Annual Retainer Client Seminar--World and U.S. Oil, October 1993. 


\section{References}

1. Yukio Arai, "Present Status and Future Prospects of Geothermal Power Generation," Japan 21st, Vol. 38, No. 3 (March 1993), pp. 45-46.

2. John Banks and Robert Ebel, "Kyrgyzstan: Problems, Opportunities." Oil \& Gas Journal, Vol. 91, No. 11 (March 15, 1993), pp. 26-27.

3. Chris Brogan, "Tantalizing Tarim to see Foreign Explorers: Openings Appear in the Great Wall," Petroleum Economist, Vol. 60, No. 4 (April 1993), pp. 12-13.

4. Helena Li Chum, Ralph Overend, and Julie A. Phillips, "The Great Energy Harvest," The Futurist, Vol. 27, No. 3 (May-June 1993), pp. 34-40.

5. Committee for Economic Development, What Price Clean Air?: A Market Approach to Energy and Environmental Policy (New York, NY, 1993).

6. Jim Dunne, "The Alternate Fuel Report: GM's Electric Car \& Dodge's CNG Fueled Van," Popular Mechanics, Vol. 169, No. 10 (October 1992), pp. 150154.

7. Mark Emond, "Look Out: Here Comes Natural Gas in the Transportation Market," National Petroleum News, Vol. 83, No. 11 (October 1991), pp. 36-41.

8. Energy Information Administration, Annual Energy Outlook 1994, DOE/EIA-0383(94) (Washington, DC, January 1994).

9. Energy Information Administration, Commercial Nuclear Power 1989, DOE/EIA-0438(89) (Washington, DC, September 1989).

10. Energy Information Administration, Emissions of Greenhouse Gases in the United States 1985-1990, DOE/EIA-0573(93) (Washington, DC, September 1993).

11. Energy Information Administration, International Energy Annual 1992, DOE/EIA-0219(92) (Washington, DC, January 1994).

12. Energy Information Administration, Weekly Petroleum Status Report, DOE/EIA-0208(93-48) (Washington, DC, November 26, 1993).

13. Energy Information Administration, World Nuclear Capacity and Fuel Cycle Requirements 1993, DOE/ EIA-0436(93) (Washington, DC, November 1993).
14. Financial Times Newsletters, International Gas Report, No. 229 (June 11, 1993), p. 30.

15. Financial Times Newsletters, International Gas Report, No. 230 (June 25, 1993), p. 30.

16. Financial Times Newsletters, International Gas Report, No. 231 (July 9, 1993), pp. 25-26.

17. Financial Times Newsletters, International Gas Report, No. 232 (July 23, 1993), p. 25.

18. Douglas Gantenbein, "Something in the Wind," Atlantic, Vol. 272, No. 4 (October 1993), pp. 36-42.

19. Carol Goldstein, "Pipelines of Plenty," Far Eastern Economic Review, Vol. 42 (October 17, 1991), pp. 108109.

20. Isabel Gorst, "Pipeline Plans Proliferate," Petroleum Economist, Vol. 60, No. 6 (June 1993), pp. 6-8.

21. Rodman D. Griffin, "Alternative Energy," $C Q$ Researcher, Vol. 2, No. 25 (July 10, 1992), pp. 575-595.

22. Hirokazu Hase, "Geothermal Programs Contributing to the Earth's Environment," Japan 21st, Vol. 38, No. 3 (March 1993), pp. 42-43.

23. Patrick Heren, "Big Players Shuffle and Shimmy," Petroleum Economist, Vol. 60, No. 5 (May 1993), pp. 49-52.

24. Patrick Heren, "Gas Export Strategy Unfolds," Petroleum Economist, Vol. 60, No. 7 (July 1993), pp. 6-7.

25. Patrick Heren, "Prices Become the Paramount Factor," Petroleum Economist, Vol. 60, No. 8 (August 1993), pp. 7-11.

26. Carl Hoffman, "Energy Futures," Audubon, Vol. 95, No. 5 (September-October 1993), pp. 112-118.

27. International Energy Agency, Climate Change Policy Initiatives (Paris, France, 1992).

28. International Energy Agency, Electricity Information 1992 (Paris, France, 1993).

29. International Energy Agency, Energy in Non-OECD Countries: Selected Topics 1991 (Paris, France, 1992).

30. International Energy Agency, Energy Policies of IEA Countries, 1991 Review (Paris, France, 1992). 
31. International Energy Agency, Global Energy: The Changing Outlook (Paris, France, 1992).

32. International Energy Agency, World Energy Outlook: To the Year 2010 (Paris, France, 1993).

33. Bjorn Larsen, World Fossil Fuel Subsidies and Clobal Carbon Emissions in a Model with Interfuel Substitution, Policy Research Working Paper, World Bank (Washington, DC, February 1994), pp. 6-8, 18-20.

34. Jon G. McGowan, "Tilting Toward Windmills," Technology Review, Vol. 95, No. 5 (July 1993), pp. 3946.

35. Roger Milne, "Britain Abandons Power from Hot Rocks," New Scientist, Vol. 129, No. 1756 (February 16, 1991), p. 27.

36. Paul Mollet, "Eastern Buyers Fret about Finding New Gas Supplies," Petroleum Economist, Vol. 60, No. 5 (May 1993), pp. 51-52.

37. Nuclear Assurance Corporation, Nuclear Power Plant Lifetime Model (Norcross, GA, May 1993).

38. Nuclear Energy Agency/International Energy Agency, Projected Costs of Generating Electricity (Washington, DC, December 1992).

39. Oak Ridge National Laboratory, The European Nuclear Power Industry: Restructuring for Combined Strength and Worldwide Leadership, ORNL-6758 (Oak Ridge, TN, June 1993).

40. Fred Pearce, "British Aid: A Hindrance as Much as a Help," New Scientist, Vol. 134, No. 1822 (May 23, 1992), pp. 12-13.

41. Petroconsultants, Inc., Worldwide Non-OPEC Crude Oil Production to 2001 (Dallas, TX, October 1992).

42. Philip Raphals, "The Hidden Cost of Canada's Cheap Power," New Scientist, Vol. 133, No. 1808 (February 15, 1992), pp. 50-54.

43. Kathleen A. Scanlan, "Tajikistan Emerges from Year-Long Civil War With Hydroelectric and Mineral Resource Opportunities," Business America, Vol. 114, No. 18 (September 6, 1993), p. 7.

44. U.S. Nuclear Regulatory Commission, Information Digest, 1993 Edition (Washington, DC, March 1993).

45. The WEFA Group, Global Petroleum Monthly, Vol. 1, No. 7 (Bala Cynwyd, PA, December 8, 1993).
46. Neville Williams, Ken Jacobson, and Harold Burris, "Sunshine for Light in the Night," Nature, Vol. 362, No. 6422 (April 22, 1993), pp. 691-692.

47. "Asia-Pacific Focus of Coming LNG Trade Boom," Oil \& Gas Journal, Vol. 90, No. 46 (November 16, 1992), pp. 26-30.

48. "Brazilian Energy Policy: Pass the Rum," The Economist, Vol. 324, No. 7766 (July 4, 1992), p. 62.

49. "Dam Collapse Raises Three Gorges Doubts," Petroleum Economist, Vol. 60, No. 10 (October 1993), pp. 58-59.

50. "Danube Dam Dispute Goes to International Court," Petroleum Economist, Vol. 60, No. 1 (January 1993), p. 36.

51. "Eastern Europe's Nuclear Power-Buying Peace of Mind," The Economist, Vol. 328, No. 7821 (July 24, 1993), pp. 19-21.

52. "Global Strategies Can Increases Third World's Energy Supply While Minimizing Emissions," Chemical \& Engineering News, Vol. 70 (July 6, 1992), pp. 12-13.

53. "Liberia Expands Hydropower," ENR, Vol. 224 (June 7, 1990), p. 27.

54. "LNG Plan Adds Up," Petroleum Economist, Vol. 60, No. 3 (March 1993), pp. 13-14.

55. "The Outlook: Growing Markets, Adequate Supplies, Moderate Prices," Oil and Gas Journal, Vol. 91, No. 43 (October 25, 1993), pp. 41-63.

56. "Plant Power," World Press Review, Vol. 39, No. 10 (October 1992), p. 44.

57. "Politics ... Always Politics," Petroleum Economist, Vol. 60, No. 2 (February 1993), pp. 31-34.

58. "The Quixotic Technology," The Economist, Vol. 325, No. 7785 (November 14, 1992), pp. 99-100.

59. "Renewable Energy: Clean Profits," The Economist, Vol. 328, No. 7830 (September 25, 1993), p. 81.

60. "The Verge of Collapse: Serbs Signal the Depth of Their Hatred by Sabotaging a Croatian Dam," Time, Vol. 141, No. 6 (February 8, 1993), pp. 18-19. 


\section{World Energy Consumption Tables}

Table A1. World Energy Consumption by Country Group and Fuel Type, 1990-2010 (Quadrillion Btu)

\begin{tabular}{|c|c|c|c|c|c|c|c|c|c|c|c|}
\hline \multirow[b]{3}{*}{ Region/Enorgy Source } & \multirow{2}{*}{\multicolumn{2}{|c|}{ History }} & \multicolumn{9}{|c|}{ Projections } \\
\hline & & & \multicolumn{3}{|c|}{2000} & \multicolumn{3}{|c|}{2005} & \multicolumn{3}{|c|}{2010} \\
\hline & 1990 & 1992 & $\begin{array}{l}\text { Base } \\
\text { Case } \\
\end{array}$ & \multicolumn{2}{|c|}{$\begin{array}{c}\text { Sensitivity } \\
\text { Range }\end{array}$} & $\begin{array}{l}\text { Base } \\
\text { Case } \\
\end{array}$ & \multicolumn{2}{|c|}{$\begin{array}{c}\text { Sensitivity } \\
\text { Range }\end{array}$} & $\begin{array}{l}\text { Base } \\
\text { Case }\end{array}$ & \multicolumn{2}{|c|}{$\begin{array}{c}\text { Sensitivity } \\
\text { Range }\end{array}$} \\
\hline \multicolumn{12}{|l|}{ OECD } \\
\hline Oil .. & 76.2 & 78.1 & 90.2 & 87.6 & 95.2 & 94.0 & 89.7 & 100.8 & 96.1 & 90.6 & 103.1 \\
\hline Natural Gas & 34.0 & 36.6 & 43.5 & 40.7 & 46.4 & 48.4 & 44.6 & 52.3 & 52.9 & 48.4 & 57.9 \\
\hline Coal. & 37.4 & 37.4 & 40.1 & 39.3 & 41.2 & 41.9 & 40.3 & 43.7 & 44.6 & 42.5 & 46.9 \\
\hline Nuclear & 16.1 & 17.4 & 18.8 & 18.8 & 19.1 & 19.2 & 19.2 & 20.0 & 18.4 & 18.4 & 20.9 \\
\hline Other & 15.4 & 15.8 & 18.6 & 17.5 & 19.7 & 20.6 & 19.0 & 22.4 & 23.3 & 21.2 & 25.6 \\
\hline$\ldots \ldots \ldots, \ldots, \ldots$ & 179.0 & 185.0 & 211.2 & 201.7 & 221.2 & 224.1 & 210.5 & 238.9 & 235.4 & 218.0 & 254.7 \\
\hline \multicolumn{12}{|l|}{ Eurasia } \\
\hline & 25.8 & 21.8 & 22.4 & 19.5 & 25.1 & 24.9 & 21.0 & 28.7 & 27.7 & 22.6 & 32.5 \\
\hline Natural Gas & 27.2 & 25.7 & 27.7 & 26.3 & 29.2 & 32.0 & 28.2 & 35.8 & 6.5 & 30.0 & 43.5 \\
\hline Coal & 41.8 & 37.9 & 46.6 & 43.5 & 49.8 & 51.0 & 46.0 & 56.7 & 55.3 & 48.1 & 63.6 \\
\hline Nuclear & 3.0 & 2.9 & 3.6 & 3.6 & 4.0 & 3.7 & 3.7 & 4.7 & 4.1 & 4.1 & 5.5 \\
\hline Other ....... & 4.3 & 4.2 & 5.8 & 5.0 & 6.7 & 6.8 & 5.7 & 8.0 & 8.2 & 6.5 & 10.2 \\
\hline Total & 102.2 & 92.4 & 106.0 & 101.0 & 112.5 & 118.4 & 108.3 & 131.0 & 131.7 & 115.8 & 151.8 \\
\hline \multicolumn{12}{|l|}{ Rest of World } \\
\hline Oil ......... & 33.4 & 36.4 & 45.6 & 44.8 & 47.7 & 49.6 & 48.2 & 56.6 & 53.1 & 51.1 & 67.4 \\
\hline Natural Gas & 10.8 & 12.1 & 15.7 & 13.1 & 18.3 & 19.7 & 13.5 & 26.3 & 24.0 & 16.7 & 32.2 \\
\hline Coal. & 12.6 & 13.7 & 15.6 & 13.8 & 17.4 & 17.4 & 14.4 & 20.5 & 19.1 & 15.0 & 23.7 \\
\hline Nuclear & 1.1 & 1.2 & 1.3 & 1.3 & 1.6 & 1.6 & 1.6 & 2.1 & 2.1 & 2.1 & 2.6 \\
\hline Other .. & 6.5 & 6.8 & 8.5 & 7.0 & 9.9 & 9.4 & 7.4 & 11.6 & 10.6 & 7.8 & 13.6 \\
\hline Total & 64.5 & 70.1 & 86.7 & 80.0 & 93.7 & 97.8 & 86.2 & 110.4 & 108.9 & 91.9 & 128.0 \\
\hline \multicolumn{12}{|l|}{ World Total } \\
\hline & 135.4 & 136.3 & 158.2 & 152.0 & 168.1 & 168.6 & 158.8 & 186.1 & 176.9 & 164.4 & 202.9 \\
\hline Natura & 72.0 & 74.3 & 86.8 & 82.8 & 91.0 & 100.0 & 92.0 & 108.5 & 113.4 & 102.6 & 125.3 \\
\hline Coal. & 91.9 & 88.9 & 102.3 & 98.5 & 106.3 & 110.3 & 104.1 & 117.3 & 119.0 & 110.2 & 129.1 \\
\hline Nuclear & 20.3 & 21.5 & 23.7 & 23.7 & 24.7 & 24.5 & 24.5 & 26.7 & 24.6 & 24.6 & 29.0 \\
\hline Other & 26.2 & 26.7 & 32.9 & 28.3 & 33.3 & 36.9 & 34.0 & 39.9 & 42.1 & 38.2 & 46.4 \\
\hline Total & 345.6 & 347.5 & 403.9 & 383.0 & 427.1 & 440.3 & 405.3 & 479.9 & 476.0 & 426.0 & 533.9 \\
\hline
\end{tabular}

OECD $=$ Organization for Economic Cooperation and Development.

Notes: Other includes hydroelectricity, geothermal, solar, biomass, wind, and other renewable sources. All sensitivity ranges are derived independently and do not necessarily add to totals. Base Case totals may not equal sum of components due to independent rounding.

Sources: History-Energy Information Administration (EIA), International Energy Annual 1992, DOE/EIA-0219(92). Projections-ElA, World Energy Projection System, 1994. 
Table A2. World Energy Consumption by Country Group, 1990-2010 (Quadrillion Btu)

\begin{tabular}{|c|c|c|c|c|c|c|c|c|c|c|c|}
\hline \multirow[b]{3}{*}{ Region/Country } & \multirow{2}{*}{\multicolumn{2}{|c|}{ History }} & \multicolumn{9}{|c|}{ Projections } \\
\hline & & & \multicolumn{3}{|c|}{2000} & \multicolumn{3}{|c|}{2005} & \multicolumn{3}{|c|}{2010} \\
\hline & \multirow[t]{2}{*}{1900} & \multirow[t]{2}{*}{1992} & $\begin{array}{l}\text { Base } \\
\text { Case }\end{array}$ & $\begin{array}{r}\text { Sensi } \\
\text { Rar }\end{array}$ & $\begin{array}{l}\text { ivity } \\
\text { ge }\end{array}$ & $\begin{array}{l}\text { Base } \\
\text { Case }\end{array}$ & $\begin{array}{r}\text { Sensh } \\
\text { Ran }\end{array}$ & $\begin{array}{l}\text { tivity } \\
\text { gee }\end{array}$ & $\begin{array}{l}\text { Base } \\
\text { Case }\end{array}$ & $\begin{array}{r}\text { Sonsh } \\
\text { Ran }\end{array}$ & $\begin{array}{l}\text { tivity } \\
\text { ge }\end{array}$ \\
\hline \multicolumn{10}{|l|}{ OECD } & & \\
\hline United States ${ }^{a} \ldots \ldots \ldots \ldots$ & 84.3 & 85.8 & 95.7 & 93.9 & 97.7 & 100.8 & 98.1 & 103.6 & 105.2 & 101.3 & 109.5 \\
\hline Canada $\ldots \ldots \ldots \ldots \ldots \ldots$ & 10.7 & 11.0 & 13.5 & 12.3 & 14.7 & 14.6 & 12.8 & 16.5 & 15.5 & 13.2 & 18.1 \\
\hline Japan $\ldots \ldots \ldots \ldots \ldots \ldots \ldots$ & 18.2 & 19.0 & 23.9 & 21.3 & 26.6 & 25.8 & 22.3 & 29.6 & 27.3 & 23.0 & 32.0 \\
\hline OECD Europe $\ldots \ldots \ldots \ldots \ldots$ & 60.8 & 64.3 & 72.6 & 67.1 & 78.4 & $\pi .1$ & 69.1 & 85.7 & 81.2 & 71.0 & 82.5 \\
\hline United Kingdom $\ldots \ldots \ldots \ldots$ & 9.0 & 9.7 & 11.7 & 10.6 & 12.8 & 12.4 & 10.9 & 14.0 & 13.0 & 11.2 & 15.1 \\
\hline France $\ldots \ldots \ldots \ldots \ldots \ldots$ & 8.9 & 9.7 & 11.1 & 10.2 & 12.0 & 11.9 & 10.6 & 13.2 & 12.5 & 10.9 & 14.3 \\
\hline Germany .............. & 14.4 & 14.1 & 16.2 & 14.2 & 18.4 & 17.3 & 14.7 & 20.2 & 18.2 & 15.1 & 21.7 \\
\hline Italy $\ldots \ldots \ldots \ldots \ldots \ldots \ldots$ & 6.8 & 7.0 & 7.9 & 7.3 & 8.5 & 8.4 & 7.5 & 9.3 & 8.8 & 7.7 & 10.0 \\
\hline Netherlands $\ldots \ldots \ldots \ldots \ldots$ & 3.3 & 3.5 & 3.8 & 3.6 & 4.1 & 4.1 & 3.7 & 4.4 & 4.3 & 3.8 & 4.7 \\
\hline Other Europe $\ldots \ldots \ldots \ldots \ldots$ & 18.6 & 20.3 & 21.9 & 21.0 & 22.7 & 23.1 & 21.7 & 24.7 & 24.5 & 22.3 & 26.8 \\
\hline Other OECD . . . . . . . . . & 4.8 & 4.9 & 5.5 & 5.2 & 5.8 & 5.9 & 5.4 & 6.3 & 6.2 & 5.6 & 6.9 \\
\hline Total OECD $\ldots \ldots \ldots \ldots \ldots$ & 179.0 & 185.0 & 211.2 & 201.7 & 221.2 & 224.1 & 210.5 & 238.9 & 235.4 & 218.0 & 254.7 \\
\hline \multicolumn{12}{|l|}{ Eurasia } \\
\hline China . & 27.9 & 29.2 & 39.7 & 35.9 & 43.8 & 46.1 & 39.6 & 53.3 & 52.6 & 43.1 & 63.7 \\
\hline Former Soviet Union . . . . . . . & 58.0 & 51.2 & 51.9 & 50.0 & 53.9 & 57.1 & 52.9 & 61.5 & 62.9 & 55.8 & 70.6 \\
\hline Eastern Europe $\ldots \ldots \ldots \ldots$ & 16.3 & 12.0 & 14.4 & 13.3 & 15.4 & 15.3 & 13.8 & 16.8 & 16.2 & 14.2 & 18.3 \\
\hline Total Eurasia $\ldots \ldots \ldots \ldots$ & 102.2 & 92.4 & 106.0 & 101.0 & 112.5 & 118.4 & 108.3 & 131.0 & 131.7 & 115.8 & 151.8 \\
\hline \multicolumn{12}{|c|}{ Rest of World (ROW) } \\
\hline OPEC $\ldots \ldots \ldots$ & 16.3 & 17.5 & 21.2 & 19.7 & 22.8 & 23.7 & 21.0 & 26.6 & 26.3 & 22.4 & 30.7 \\
\hline Other ROW. & 48.1 & 52.6 & 65.5 & 60.4 & 71.0 & 74.1 & 65.1 & 83.8 & 82.6 & 69.5 & 97.3 \\
\hline Total Row $\ldots \ldots \ldots \ldots$ & 64.5 & 70.1 & 86.7 & 80.0 & 93.7 & 97.8 & 86.2 & 110.4 & 108.9 & 91.9 & 128.0 \\
\hline World Total ............... & 345.6 & 347.5 & 403.9 & 383.0 & 427.1 & 440.3 & 405.3 & 479.9 & 476.0 & 426.0 & 533.9 \\
\hline
\end{tabular}

ancludes the 50 States and the District of Columbia. U.S. Territories are included in "Other OECD."

OECD = Organization for Economic Comperation and Development.

OPEC = Organization of Petroleum Exporting Countries.

Notes: All sensitivity ranges are derived independently and do not necessarily add to totals. Base Case totals may not equal sum of components due to independent rounding. Country amounts include an adjustment to account for electricity trade.

Sources: History-Energy Information Administration (EIA), International Energy Annual 1992, DOE/ElA-0219(92). Projections-EIA, Annual Energy Outlook 1994, DOE/EIA-0383(94), Tables A1, B1, and C1, and World Energy Projection System, 1994. 
Table A3. World Oll Consumption by Country Group, 1990-2010 (Million Barrels per Day)

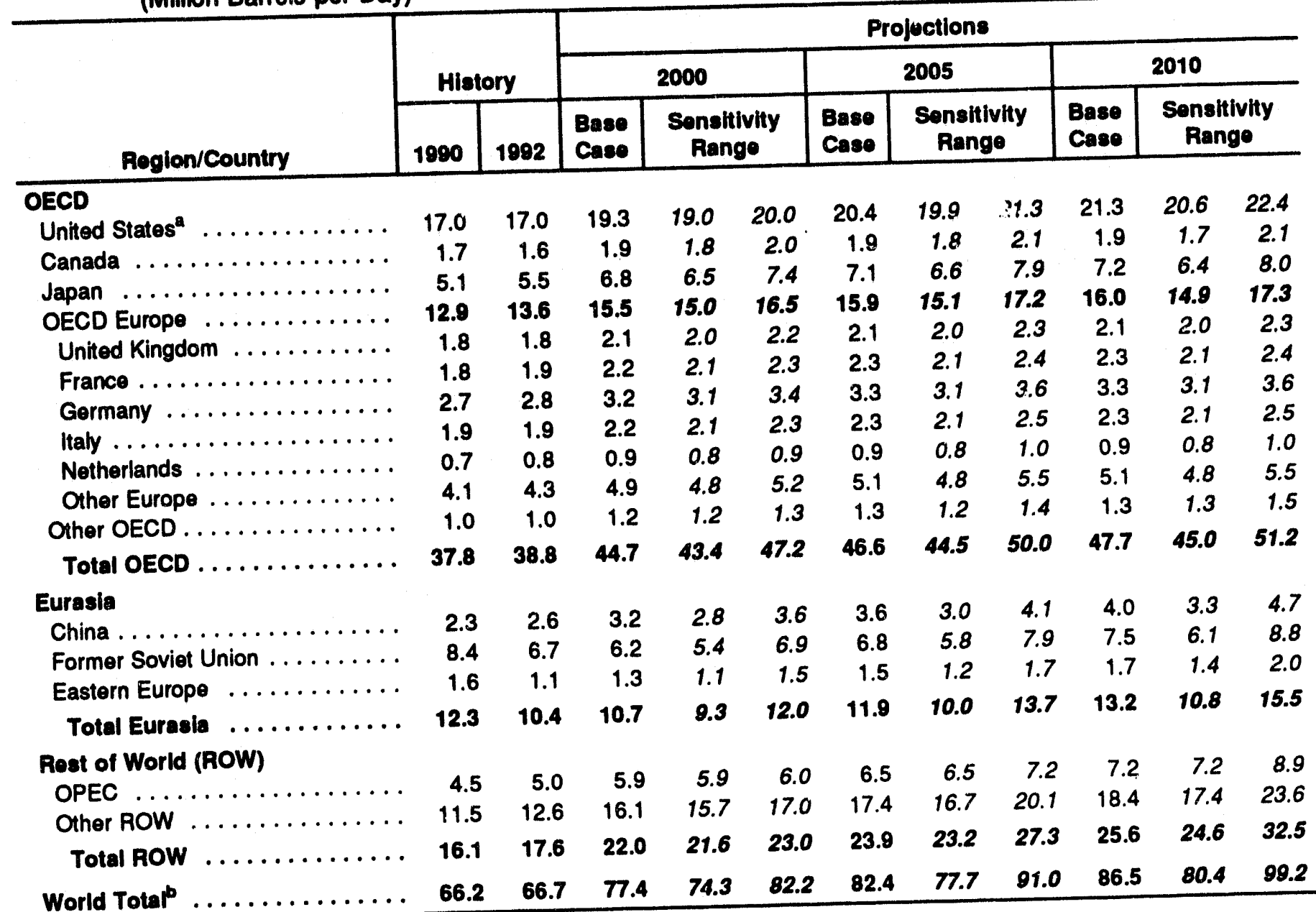

ancludes the 50 States and the District of Columbia. U.S. Territories are included in "Other OECD."

bHigh range for ROW is derived from International Energy Agency, World Energy Outlook, 1993. Therefore, total is not constrained by capacities listed in Table 6.

OECD = Organization for Economic Cooperation and Development.

OPEC = Organization of Petroleum Exporting Countries.

Notes: Totals may not equal sum of components due to independent rounding. Country amounts include an adjustment to account for electricity trade.

Sources: History-Energy Information Administration (EIA), International Energy Annual 1992, DOE/EIA-0219(92). Projections-EIA, Annual Energy Outlook 1994, DOE/EIA-0383(94), Tables A11, D11, and E11, and World Energy Projection System, 1994. 
Table A4. World Natural Gas Consumption by Country Group, 1990-2010 (Trillion Cubic Feet)

\begin{tabular}{|c|c|c|c|c|c|c|c|c|c|c|c|}
\hline \multirow[b]{3}{*}{ Region/Country } & \multirow{2}{*}{\multicolumn{2}{|c|}{ History }} & \multicolumn{9}{|c|}{ Projections } \\
\hline & & & \multicolumn{3}{|c|}{2000} & \multicolumn{3}{|c|}{2005} & \multicolumn{3}{|c|}{2010} \\
\hline & \multirow[t]{2}{*}{1990} & \multirow[t]{2}{*}{1992} & \multirow[t]{2}{*}{$\begin{array}{l}\text { Base } \\
\text { Case }\end{array}$} & $\begin{array}{r}\text { Sensi } \\
\text { Ran }\end{array}$ & $\begin{array}{l}\text { vity } \\
10\end{array}$ & $\begin{array}{l}\text { Base } \\
\text { Case } \\
\end{array}$ & $\begin{array}{r}\text { Sensi } \\
\text { Ran } \\
\end{array}$ & Ivity & $\begin{array}{l}\text { Base } \\
\text { Case }\end{array}$ & $\begin{array}{r}\text { Sensit } \\
\text { Ran }\end{array}$ & ivity \\
\hline \multicolumn{9}{|l|}{ OECD } & & & \\
\hline United States ${ }^{a} \ldots \ldots \ldots \ldots$ & 18.7 & 19.7 & 22.0 & 21.5 & 22.7 & 23.6 & 22.5 & 24.5 & 24.1 & 23.1 & 25.3 \\
\hline 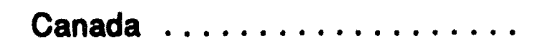 & 2.4 & 2.6 & 2.8 & 2.7 & 3.0 & 3.0 & 2.7 & 3.3 & 3.1 & 2.8 & 3.6 \\
\hline$\ldots \ldots \ldots \ldots \ldots \ldots$ & 1.9 & 2.0 & 2.6 & 1.7 & 3.6 & 2.9 & 1.7 & 4.1 & 3.5 & 1.8 & 5.3 \\
\hline OECD Europo $\ldots \ldots \ldots \ldots \ldots$ & 10.3 & 10.9 & 14.7 & 12.2 & 17.4 & 17.5 & 14.1 & 21.0 & 20.5 & 16.5 & 24.9 \\
\hline United Kingdom . . . . . . . . . & 2.1 & 2.2 & 3.8 & 2.7 & 4.9 & 4.5 & 2.9 & 6.1 & 5.2 & 3.3 & 7.3 \\
\hline France $\ldots \ldots \ldots \ldots \ldots \ldots$ & 1.0 & 1.1 & 1.5 & 0.6 & 2.4 & 1.9 & 0.6 & 3.3 & 2.4 & 0.8 & 4.2 \\
\hline Germany ............... & 2.6 & 2.7 & 3.9 & 1.9 & 6.1 & 4.5 & 2.1 & 7.1 & 5.1 & 2.3 & 8.1 \\
\hline Italy $\ldots \ldots \ldots \ldots \ldots \ldots$ & 1.7 & 1.7 & 1.9 & 1.6 & 2.2 & 2.2 & 1.6 & 2.8 & 2.4 & 1.7 & 3.2 \\
\hline Netherlands $\ldots \ldots \ldots \ldots \ldots$ & 1.6 & 1.7 & 1.8 & 1.6 & 2.0 & 1.9 & 1.6 & 2.2 & 2.0 & 1.7 & 2.3 \\
\hline Other Europe . . . . . . . . . & 1.3 & 1.5 & 1.8 & 1.2 & 2.3 & 2.5 & 1.6 & 3.4 & 3.4 & 2.0 & 4.7 \\
\hline Other OECD $\ldots \ldots \ldots \ldots \ldots$ & 0.8 & 0.8 & 0.9 & 0.8 & 1.1 & 1.0 & 0.8 & 1.3 & 1.1 & 0.8 & 1.4 \\
\hline Total OECD $\ldots \ldots \ldots \ldots \ldots$ & 34.1 & 36.0 & 43.1 & 40.3 & 46.0 & 47.9 & 44.2 & 51.8 & 52.4 & 47.9 & 57.3 \\
\hline \multicolumn{12}{|l|}{ Eurasia } \\
\hline China...$\ldots \ldots \ldots$ & 0.5 & 0.5 & 0.9 & 0.7 & 1.1 & 1.1 & 0.8 & 1.4 & 1.3 & 0.9 & 1.7 \\
\hline Former Soviet Union. & 25.0 & 24.1 & 25.0 & 23.7 & 26.3 & 28.8 & 25.1 & 32.6 & 32.9 & 26.3 & 40.0 \\
\hline Eastern Europe $\ldots$. & 3.1 & 2.5 & 3.2 & 2.5 & 3.9 & 3.6 & 2.5 & 4.9 & 4.1 & 2.3 & 6.1 \\
\hline Total Eurasia $\ldots \ldots \ldots \ldots$ & 28.6 & 27.1 & 29.1 & 27.6 & 30.6 & 33.6 & 29.7 & 37.6 & 38.3 & 31.5 & 45.7 \\
\hline \multicolumn{12}{|l|}{ Rest of World (ROW) } \\
\hline OPEC $\ldots \ldots \ldots$ & 5.6 & 6.0 & 7.4 & 6.2 & 8.7 & 8.4 & 6.3 & 10.8 & 9.4 & 6.3 & 12.9 \\
\hline Other ROW $\ldots \ldots$ & 4.8 & 5.6 & 7.7 & 5.5 & 9.9 & 10.6 & 6.5 & 15.1 & 13.9 & 7.5 & 21.1 \\
\hline Total ROW ..... & 10.4 & 11.6 & 15.2 & 12.6 & 17.7 & 19.1 & 13.1 & 25.4 & 23.3 & 16.2 & 31.3 \\
\hline World Total ............... & 73.1 & 74.7 & 87.3 & 83.3 & 91.5 & 100.6 & 92.5 & 109.1 & 114.0 & 103.1 & 126.0 \\
\hline
\end{tabular}

alncludes the 50 States and the District of Columbia. U.S. Territories are included in "Other OECD."

$O E C D=$ Organization for Economic Cooperation and Development.

OPEC = Organization of Petroleum Exporting Countries.

Notes: All sensitivity ranges are derived independently and do not necessarily add to totals. Range values for OECD Europe, the three regional totals, and the world are not equal to the sums for the component countries or country groups but consist of the base value adjusted by the square root of the sum of the squared deviations of the respective component countries or country groups from their base values. Base Case totals may not equal sum of components due to independent rounding. Country amounts include an adjustment to account for electricity trade. To convert cubic feet to cubic meters, divide each number in this table by 35.315 .

Sources: History-Energy Information Administration (EIA), International Energy Annual 1992, DOE/ElA-0219(92). Projections-EIA, Annual Energy Outlook 1994, DOE/EIA-0383(94), Tables A13, B13, and C13, and World Energy Projection System, 1994. 
Table A5. World Coal Consumption by Country Group, 1990-2010 (Million Short Tons)

\begin{tabular}{|c|c|c|c|c|c|c|c|c|c|c|c|}
\hline \multirow[b]{3}{*}{ Rogion/Country } & \multirow{2}{*}{\multicolumn{2}{|c|}{ History }} & \multicolumn{9}{|c|}{ Projectlons } \\
\hline & & & \multicolumn{3}{|c|}{2000} & \multicolumn{3}{|c|}{2005} & \multicolumn{3}{|c|}{2010} \\
\hline & 1990 & 1992 & $\begin{array}{l}\text { Base } \\
\text { Caso }\end{array}$ & \multicolumn{2}{|c|}{$\begin{array}{c}\text { Sonsitivity } \\
\text { Range }\end{array}$} & $\begin{array}{l}\text { Base } \\
\text { Case }\end{array}$ & \multicolumn{2}{|c|}{$\begin{array}{c}\text { Sensitivity } \\
\text { Range }\end{array}$} & $\begin{array}{l}\text { Base } \\
\text { Case }\end{array}$ & \multicolumn{2}{|c|}{$\begin{array}{c}\text { Sensitivity } \\
\text { Range }\end{array}$} \\
\hline$\ldots \ldots \ldots \ldots \ldots$ & 895 & 892 & 958 & 939 & 971 & 987 & 976 & 1,009 & 1,079 & 1,023 & 1,142 \\
\hline Canada ............... & 58 & 56 & 75 & 59 & 88 & 80 & 65 & 96 & 82 & 65 & 100 \\
\hline Japan $\ldots \ldots \ldots \ldots \ldots \ldots$ & 125 & 125 & 149 & 121 & 196 & 170 & 98 & 245 & 178 & 101 & 260 \\
\hline OECD Europo $\ldots \ldots \ldots \ldots \ldots$ & 930 & 804 & 826 & 801 & 851 & 859 & 815 & 805 & 889 & 835 & 949 \\
\hline United Kingdom . . . . . . . . . & 110 & 119 & 119 & 118 & 120 & 116 & 113 & 119 & 116 & 113 & 119 \\
\hline France $\ldots \ldots \ldots \ldots \ldots$ & 39 & 37 & 33 & 29 & 38 & 30 & 22 & 38 & 26 & 15 & 37 \\
\hline Germany .............. & 509 & 363 & 341 & 324 & 358 & 343 & 310 & 380 & 336 & 296 & 384 \\
\hline Itaby $\ldots \ldots \ldots \ldots \ldots \ldots$ & 23 & 21 & 24 & 15 & 33 & 25 & 15 & 34 & 27 & 16 & 37 \\
\hline Notherlands . . . . . . . . . . & 16 & 13 & 14 & 12 & 15 & 15 & 13 & 17 & 15 & 13 & 18 \\
\hline Other Europe $\ldots \ldots \ldots \ldots \ldots$ & 233 & 250 & 259 & 242 & 273 & 276 & 251 & 300 & 293 & 260 & 326 \\
\hline Other OECD $\ldots \ldots \ldots \ldots \ldots \ldots$ & 111 & 122 & 129 & 122 & 135 & 132 & 122 & 142 & 134 & 122 & 145 \\
\hline Total OECD .. & 2,110 & 2,000 & 2,137 & 2,091 & 2,194 & 2,228 & 2,140 & 2,320 & 2,362 & 2,250 & 2,483 \\
\hline \multicolumn{12}{|l|}{ Eurasia } \\
\hline China . . . . . . . . & 1,145 & 1,204 & 1,632 & 1,449 & 1,827 & 1,875 & 1,573 & 2,214 & 2,112 & 1,683 & 2,605 \\
\hline Former Soviet Union . . . . . . . . . & 744 & 643 & 665 & 629 & 703 & 675 & 633 & 719 & 685 & 637 & 736 \\
\hline Eastern Europe $\ldots \ldots \ldots \ldots \ldots$ & 527 & 487 & 536 & 512 & 549 & 529 & 513 & 549 & 515 & 495 & 534 \\
\hline Total Eurasia $\ldots . . . \ldots \ldots$ & 2,416 & 2,334 & 2,833 & 2,645 & 3,032 & 3,079 & 2,773 & 3,421 & 3,312 & 2,881 & 3,811 \\
\hline \multicolumn{12}{|c|}{ Rest of World (ROW) } \\
\hline OPEC $\ldots \ldots \ldots \ldots \ldots \ldots$ & 11 & 12 & 15 & 12 & 17 & 16 & 13 & 20 & 18 & 13 & 24 \\
\hline Other ROW .. & 626 & 655 & 748 & 658 & 837 & 832 & 686 & 987 & 915 & 712 & 1,140 \\
\hline Total Row $\ldots \ldots \ldots . . .$. & 637 & 668 & 763 & 673 & 852 & 848 & 702 & 1,003 & 933 & 730 & 1,158 \\
\hline World Total .... & 5,172 & 5,001 & 5,732 & 5,520 & 5,958 & 6,155 & 5,805 & 6,542 & 6,606 & 6,117 & 7,167 \\
\hline
\end{tabular}

ancludes the 50 States and the District of Columbia. U.S. Territories are included in "Other OECD."

OECD = Organization for Economic Cooperation and Development.

OPEC $=$ Organization of Petroleum Exporting Countries.

Notes: All sensitivity ranges are derived independently and do not necessarily add to totals. Range values for OECD Europe, the three regional totals, and the world are not equal to the sums for the component countries or country groups but consist of the base value adjusted by the square root of the sum of the squared deviations of the respective component countries or country groups from their base values. Base Case totals may not equal sum of components due to independent rounding. Country amounts include an adjustment to account for electricity trade. To convert short tons to metric tons, divide each number in this table by 1.102 .

Sources: History-Energy Information Administration (ElA), International Energy Annual 1992, DOE/EIA-0219(92). Projectione-EIA, Annual Energy Outlook 1994, DOE/EIA-0383(94), Tables A15, B15, and C15, and World Energy Projection System, 1994. 
Table A6. World Nuclear Energy Consumpilon by Country Group, 1990-2010 (Billion Kilowatthours)

\begin{tabular}{|c|c|c|c|c|c|c|c|c|c|c|c|}
\hline \multirow[b]{3}{*}{ Region/Country } & \multirow{2}{*}{\multicolumn{2}{|c|}{ History }} & \multicolumn{9}{|c|}{ Projoctions } \\
\hline & & & \multicolumn{3}{|c|}{2000} & \multicolumn{3}{|c|}{2005} & \multicolumn{3}{|c|}{2010} \\
\hline & 1990 & 1992 & $\begin{array}{l}\text { Base } \\
\text { Case }\end{array}$ & \multicolumn{2}{|c|}{$\begin{array}{c}\text { Sonsitivity } \\
\text { Range }\end{array}$} & $\begin{array}{l}\text { Baso } \\
\text { Case }\end{array}$ & \multicolumn{2}{|c|}{$\begin{array}{c}\text { Sensitivity } \\
\text { Range }\end{array}$} & $\begin{array}{l}\text { Base } \\
\text { Case }\end{array}$ & \multicolumn{2}{|c|}{$\begin{array}{c}\text { Sensitivity } \\
\text { Range }\end{array}$} \\
\hline \multicolumn{2}{|l|}{ OECD } & & & & & & & & & & \\
\hline United States ${ }^{\mathrm{a}}$ & 577 & 619 & 671 & 671 & 671 & 680 & 680 & 680 & 612 & 612 & 612 \\
\hline Canada ..... & 69 & 76 & 91 & 91 & 91 & 96 & 96 & 119 & 101 & 101 & 150 \\
\hline Japan . & 182 & 207 & 266 & 266 & 290 & 287 & 287 & 318 & 307 & 307 & 373 \\
\hline OECD Europe . . & 692 & 736 & 745 & 745 & 752 & 745 & 745 & 767 & 722 & 722 & 844 \\
\hline United Kingdom . . . . . . . . & 63 & 80 & 71 & 71 & 71 & 67 & 67 & 68 & 49 & 49 & 55 \\
\hline France $\ldots \ldots \ldots \ldots \ldots$ & 261 & 281 & 331 & 331 & 338 & 355 & 355 & 362 & 362 & 362 & 400 \\
\hline Germany .............. & 147 & 153 & 144 & 144 & 144 & 150 & 150 & 150 & 152 & 152 & 164 \\
\hline Italy $\ldots \ldots \ldots \ldots \ldots \ldots$ & 12 & 13 & 15 & 15 & 15 & 16 & 16 & 16 & 16 & 16 & 25 \\
\hline Netherlands $\ldots \ldots \ldots \ldots \ldots$ & 6 & 7 & 6 & 6 & 6 & 4 & 4 & 4 & 4 & 4 & 14 \\
\hline Other Europe $\ldots \ldots \ldots \ldots \ldots$ & 203 & 202 & 180 & 180 & 180 & 154 & 154 & 167 & 139 & 139 & 185 \\
\hline Crher OECD $\ldots \ldots \ldots \ldots \ldots$ & 0 & 0 & 0 & 0 & 0 & 0 & 0 & 0 & 0 & 0 & 0 \\
\hline Total OECD $\ldots \ldots \ldots \ldots \ldots$ & 1,520 & 1,638 & 1,773 & 1,773 & 1,803 & 1,808 & 1,808 & 1,883 & 1,742 & 1,742 & 1,979 \\
\hline \multicolumn{12}{|l|}{ Eurasia } \\
\hline Chine . . . . . . . . . . . & 0 & 0 & 14 & 14 & 14 & 17 & 17 & 17 & 19 & 19 & 28 \\
\hline Former Soviet Union . . . . . . . & 197 & 203 & 223 & 223 & 249 & 223 & 223 & 282 & 247 & 247 & 328 \\
\hline Eastern Europe $\ldots \ldots \ldots \ldots$ & 69 & 62 & 86 & 86 & 97 & 94 & 94 & 122 & 101 & 101 & 141 \\
\hline Total Eurasia & 266 & 265 & 323 & 323 & 360 & 334 & 334 & 421 & 367 & 367 & 497 \\
\hline \multicolumn{12}{|l|}{ Rest of World (ROW) } \\
\hline OPEC $\ldots \ldots \ldots \ldots \ldots \ldots$ & 0 & 0 & 0 & 0 & 0 & 0 & 0 & 0 & 0 & 0 & 0 \\
\hline Other Row $\ldots \ldots \ldots \ldots \ldots$ & 107 & 114 & 130 & 130 & 155 & 158 & 158 & 207 & 204 & 204 & 256 \\
\hline Total ROW . & 107 & 114 & 130 & 130 & 155 & 158 & 158 & 207 & 204 & 204 & 256 \\
\hline World Total ....... & 1,894 & 2,017 & 2,226 & 2,226 & 2,319 & 2,299 & 2,299 & 2,512 & 2,313 & 2,313 & 2,732 \\
\hline
\end{tabular}

ancludes the 50 States and the District of Columbia. U.S. Territories are included in "Other OECD."

$O E C D=$ Organization for Economic Cooperation and Development.

OPEC = Organization of Petroleum Exporting Countries.

Notes: Totals may not equal sum of components due to independent rounding. Country amounts include an adjustment to account for electricity trade.

Sources: History-Energy Information Administration (EIA), International Energy Annual 1992, DOE/EIA-0219(92). Projections-EIA, Annual Energy Outlook 1994, DOE/EIA-0383(94), Tables A8, B8, and C8, and World Energy Projection System, 1994. 
Table A7. World Hydroelectrlclty and Other Renewable Energy Consumption by Country Group, 1990-2010 (Quadrillion Btu)

\begin{tabular}{|c|c|c|c|c|c|c|c|c|c|c|c|}
\hline \multirow[b]{3}{*}{ Region/Country } & \multirow{2}{*}{\multicolumn{2}{|c|}{ History }} & \multicolumn{9}{|c|}{ Projections } \\
\hline & & & \multicolumn{3}{|c|}{2000} & \multicolumn{3}{|c|}{2005} & \multicolumn{3}{|c|}{2010} \\
\hline & 1990 & 1992 & $\begin{array}{l}\text { Base } \\
\text { Case }\end{array}$ & \multicolumn{2}{|c|}{$\begin{array}{c}\text { Sonsitivity } \\
\text { Range }\end{array}$} & $\begin{array}{l}\text { Base } \\
\text { Case }\end{array}$ & \multicolumn{2}{|c|}{$\begin{array}{c}\text { Sensitivity } \\
\text { Range }\end{array}$} & $\begin{array}{l}\text { Base } \\
\text { Case }\end{array}$ & \multicolumn{2}{|c|}{$\begin{array}{c}\text { Sensitivity } \\
\text { Range }\end{array}$} \\
\hline \multicolumn{12}{|l|}{ OECD } \\
\hline United States ${ }^{a}$ & 6.2 & 6.4 & 7.3 & 7.2 & 7.4 & 7.9 & 7.8 & 8.1 & 8.9 & 8.7 & 9.3 \\
\hline Canada $\ldots \ldots \ldots \ldots \ldots \ldots$ & 3.0 & 3.0 & 4.1 & 3.4 & 4.9 & 4.9 & 3.6 & 6.1 & 5.5 & 3.8 & 7.3 \\
\hline Japan $\ldots \ldots \ldots \ldots \ldots \ldots$ & 1.0 & 1.0 & 1.4 & 0.6 & 2.2 & 1.7 & 0.6 & 2.8 & 2.0 & 0.7 & 3.3 \\
\hline OECD Europe & 4.7 & 5.0 & 5.2 & 5.0 & 5.4 & 5.6 & 5.3 & 5.9 & 6.3 & 5.8 & 6.8 \\
\hline United Kingdom & 0.1 & 0.1 & 0.1 & 0.1 & 0.2 & 0.2 & 0.1 & 0.2 & 0.2 & 0.2 & 0.3 \\
\hline$\ldots \ldots \ldots \ldots \ldots$ & 0.5 & 0.7 & 0.7 & 0.7 & 0.7 & 0.7 & 0.7 & 0.7 & 0.7 & 0.7 & 0.8 \\
\hline$\ldots \ldots \ldots \ldots \ldots$ & 0.4 & 0.3 & 0.3 & 0.3 & 0.3 & 0.4 & 0.3 & 0.4 & 0.4 & 0.3 & 0.5 \\
\hline Italy $\ldots \ldots \ldots \ldots \ldots \ldots$ & 0.5 & 0.6 & 0.6 & 0.5 & 0.7 & 0.7 & 0.5 & 0.8 & 0.7 & 0.6 & 0.9 \\
\hline Netherlands $\ldots \ldots \ldots \ldots \ldots$ & 0.0 & 0.0 & 0.0 & 0.0 & 0.1 & 0.1 & 0.0 & 0.2 & 0.2 & 0.1 & 0.4 \\
\hline Other Europe $\ldots \ldots \ldots \ldots \ldots$ & 3.2 & 3.3 & 3.4 & 3.3 & 3.6 & 3.6 & 3.4 & 3.9 & 3.9 & 3.5 & 4.3 \\
\hline Other OECD . . & 0.4 & 0.4 & 0.5 & 0.4 & 0.6 & 0.6 & 0.4 & 0.7 & 0.7 & 0.4 & 1.0 \\
\hline Total OECD $\ldots \ldots \ldots \ldots \ldots$ & 15.4 & 15.8 & 18.6 & 17.5 & 19.7 & 20.6 & 19.0 & 22.4 & 23.3 & 21.2 & 25.6 \\
\hline \multicolumn{12}{|l|}{ Eurasia } \\
\hline China...$\ldots \ldots \ldots$ & 1.3 & 1.4 & 2.4 & 1.9 & 2.8 & 3.2 & 2.3 & 4.1 & 4.4 & 2.9 & 6.1 \\
\hline Former Soviet Union . . . . . . . . & 2.4 & 2.3 & 2.7 & 2.1 & 3.4 & 2.9 & 2.2 & 3.6 & 3.1 & 2.2 & 3.9 \\
\hline Eastern Europe $\ldots \ldots \ldots \ldots$ & 0.6 & 0.5 & 0.7 & 0.5 & 1.0 & 0.7 & 0.5 & 1.0 & 0.8 & 0.5 & 1.1 \\
\hline Total Eurasia $\ldots \ldots \ldots \ldots$ & 4.3 & 4.2 & 5.8 & 5.0 & 6.7 & 6.8 & 5.7 & 8.0 & 8.2 & 6.5 & 10.2 \\
\hline \multicolumn{12}{|l|}{ Rest of World (ROW) } \\
\hline OPEC $\ldots \ldots \ldots \ldots$ & 0.5 & 0.5 & 0.7 & 0.6 & 0.9 & 0.8 & 0.6 & 1.1 & 1.0 & 0.6 & 1.5 \\
\hline Other ROW & 6.0 & 6.3 & 7.7 & 6.2 & 9.2 & 8.6 & 6.5 & 10.8 & 9.6 & 6.8 & 12.5 \\
\hline Total ROW $\ldots \ldots \ldots \ldots \ldots$ & 6.5 & 6.8 & 8.5 & 7.0 & 9.9 & 9.4 & 7.4 & 11.6 & 10.6 & 7.8 & 13.6 \\
\hline World Total $\ldots \ldots \ldots \ldots \ldots \ldots$ & 26.2 & 26.7 & 32.9 & 28.3 & 33.3 & 36.9 & 34.0 & 39.9 & 42.1 & 38.2 & 46.4 \\
\hline
\end{tabular}

ancludes the 50 States and the District of Columbia. U.S. Territories are included in "Other OECD."

OECD = Organization for Economic Cooperation and Development.

OPEC = Organization of Petroleum Exporting Countries.

Notes: All sensitivity ranges are derived independently and do not necessarily add to totals. Range values for OECD Europe, the three regional totals, and the world are not equal to the sums for the component countries or country groups but consist of the base value adjusted by the square root of the sum of the squared deviations of the respective component countries or country groups from their base values. Base Case totals may not equal sum of components due to independent rounding. Country amounts include an adjustment to account for electricity trade. To convert to exajoules, divide each number in this table by 0.9478 .

Sources: History-Energy Information Administration (EIA), International Energy Annual 1992, DOE/EIA-0219(92). Projectione-EIA, Annual Energy Outlook 1994, DOE/EIA-0383(94), Tables A1, B1, and C1, and World Energy Projection System, 1994. 
Table A8. World Energy Consumption by Country Group and Fuel Type, 1990-2010 (Exajoules)

\begin{tabular}{|c|c|c|c|c|c|c|c|c|c|c|c|}
\hline \multirow[b]{2}{*}{ Rogion/Enorgy Source } & & & \multicolumn{9}{|c|}{ Projections } \\
\hline & 1980 & 1892 & $\begin{array}{l}\text { Base } \\
\text { Case }\end{array}$ & \multicolumn{2}{|c|}{$\begin{array}{c}\text { Sonsitivity } \\
\text { Range }\end{array}$} & $\begin{array}{l}\text { Bese } \\
\text { Caseo }\end{array}$ & \multicolumn{2}{|c|}{$\begin{array}{c}\text { Sonshivity } \\
\text { Range }\end{array}$} & $\begin{array}{l}\text { Base } \\
\text { Case }\end{array}$ & \multicolumn{2}{|c|}{$\begin{array}{c}\text { Sonsitivity } \\
\text { Range }\end{array}$} \\
\hline \multicolumn{12}{|l|}{ OECD } \\
\hline Oil $\ldots \ldots \ldots \ldots \ldots \ldots \ldots$ & 80.4 & 82.4 & 95.1 & 92.5 & 100.4 & 99.1 & 94.6 & 106.4 & 101.4 & 95.6 & 108.8 \\
\hline Natural Gas . . . . . . . . . . . & 35.9 & 38.6 & 45.9 & 42.9 & 49.0 & 51.1 & 47.1 & 55.2 & 55.9 & 51.0 & 61.1 \\
\hline Coal ................ & 39.4 & 39.4 & 42.4 & 41.5 & 43.5 & 44.2 & 42.5 & 46.1 & 47.0 & 44.8 & 49.5 \\
\hline Nuclear $\ldots \ldots \ldots \ldots \ldots \ldots$ & 17.0 & 18.4 & 19.8 & 19.8 & 20.2 & 20.2 & 20.2 & 21.1 & 19.4 & 19.4 & 22.1 \\
\hline Other $\ldots \ldots \ldots \ldots \ldots \ldots$ & 16.3 & 16.6 & 19.6 & 18.4 & 20.8 & 21.8 & 20.0 & 23.6 & 24.6 & 22.3 & 27.1 \\
\hline Total ................ & 188.8 & 185.2 & 222.8 & 212.9 & 233.4 & 236.4 & 222.1 & 252.1 & 248.3 & 230.0 & 268.7 \\
\hline \multicolumn{12}{|c|}{ Eurasia } \\
\hline Oil $\ldots \ldots \ldots \ldots \ldots \ldots \ldots$ & 27.3 & 23.0 & 23.7 & 20.6 & 26.5 & 26.3 & 22.1 & 30.3 & 29.2 & 23.9 & 34.3 \\
\hline Natural Gas . . . . . . . . . . . & 28.7 & 27.1 & 29.2 & 27.7 & 30.8 & 33.7 & 29.8 & 37.7 & 38.5 & 31.6 & 45.9 \\
\hline Coal . . . . . . . . . . . . & 44.1 & 40.0 & 49.1 & 45.9 & 52.6 & 53.8 & 48.5 & 59.8 & 58.3 & 50.8 & 67.2 \\
\hline Nuclear $\ldots \ldots \ldots \ldots \ldots \ldots$ & -2 & 3.1 & 3.8 & 3.8 & 4.2 & 3.9 & 3.9 & 4.9 & 4.3 & 4.3 & 5.8 \\
\hline Other $\ldots \ldots \ldots \ldots \ldots \ldots$ & 4.5 & 4.4 & 6.1 & 5.3 & 7.0 & 7.2 & 6.0 & 8.5 & 8.7 & 6.9 & 10.8 \\
\hline Total $\ldots \ldots \ldots \ldots \ldots \ldots \ldots$ & 107.8 & 97.5 & 111.8 & 106.5 & 118.6 & 125.0 & 114.3 & 138.3 & 139.0 & 122.2 & 160.1 \\
\hline \multicolumn{12}{|c|}{ Reat of World } \\
\hline Oil $\ldots \ldots \ldots \ldots \ldots \ldots \ldots \ldots$ & 35.2 & 38.4 & 48.1 & 47.3 & 50.3 & 52.4 & 50.8 & 59.8 & 56.0 & 53.9 & 71.1 \\
\hline Natural Gas . . . . . . . . . . . & 11.4 & 12.7 & 16.6 & 13.8 & 19.3 & 20.8 & 14.3 & 27.7 & 25.3 & 17.6 & 34.0 \\
\hline Coal ................. & 13.3 & 14.4 & 16.5 & 14.5 & 18.4 & 18.3 & 15.2 & 21.7 & 20.2 & 15.8 & 25.0 \\
\hline Nuclear $\ldots \ldots \ldots \ldots \ldots \ldots$ & 1.2 & 1.2 & 1.4 & 1.4 & 1.7 & 1.7 & 1.7 & 2.2 & 2.2 & 2.2 & 2.8 \\
\hline Other $\ldots \ldots \ldots \ldots \ldots \ldots$ & 6.9 & 7.2 & 8.9 & 7.3 & 10.5 & 10.0 & 7.8 & 12.3 & 11.2 & 8.3 & 14.3 \\
\hline Total $\ldots \ldots \ldots \ldots \ldots \ldots \ldots$ & 68.0 & 74.0 & 91.5 & 84.4 & 98.9 & 103.1 & 90.9 & 116.4 & 114.9 & 96.9 & 135.0 \\
\hline \multicolumn{12}{|l|}{ World Total } \\
\hline Oil $\ldots \ldots \ldots \ldots \ldots \ldots \ldots$ & 142.8 & 143.8 & 166.9 & 160.3 & 177.3 & 177.8 & 167.6 & 196.3 & 186.6 & 173.4 & 214.0 \\
\hline Natural Gas . . . . . . . . . . . & 76.0 & 78.4 & 91.6 & 87.4 & 96.0 & 105.6 & 97.1 & 114.4 & 119.7 & 108.3 & 132.2 \\
\hline Coal. ................. & 96.9 & 93.8 & 108.0 & 103.9 & 112.2 & 116.4 & 109.8 & 123.7 & 125.5 & 116.2 & 136.2 \\
\hline Nuclear $\ldots \ldots \ldots \ldots \ldots \ldots$ & 21.4 & 22.7 & 25.0 & 25.0 & 26.1 & 25.8 & 25.8 & 28.2 & 25.9 & 25.9 & 30.6 \\
\hline Other $\ldots \ldots \ldots \ldots \ldots \ldots$ & 27.6 & 28.2 & 34.7 & 29.8 & 35.1 & 38.9 & 35.9 & 42.1 & 44.5 & 40.3 & 49.0 \\
\hline Total $\ldots \ldots \ldots \ldots \ldots \ldots \ldots$ & 364.6 & 366.7 & 426.2 & 404.1 & 450.6 & 464.5 & 427.6 & 506.3 & 502.2 & 449.4 & 563.3 \\
\hline
\end{tabular}

OECD = Organization for Economic Cooperation and Development.

Notes: Other includes hydroelectricity, geothermal, solar, biomass, wind, and other renewable sources. All sensitivity ranges are derived independently and do not necessarily add to totals. Base Case totals may not equal sum of components due to independent rounding.

Source: Data from Table A1, divided by the conversion factor 0.9478 . 
Table A9. World Energy Consumption by Country Group, 1990-2010 (Exajoules)

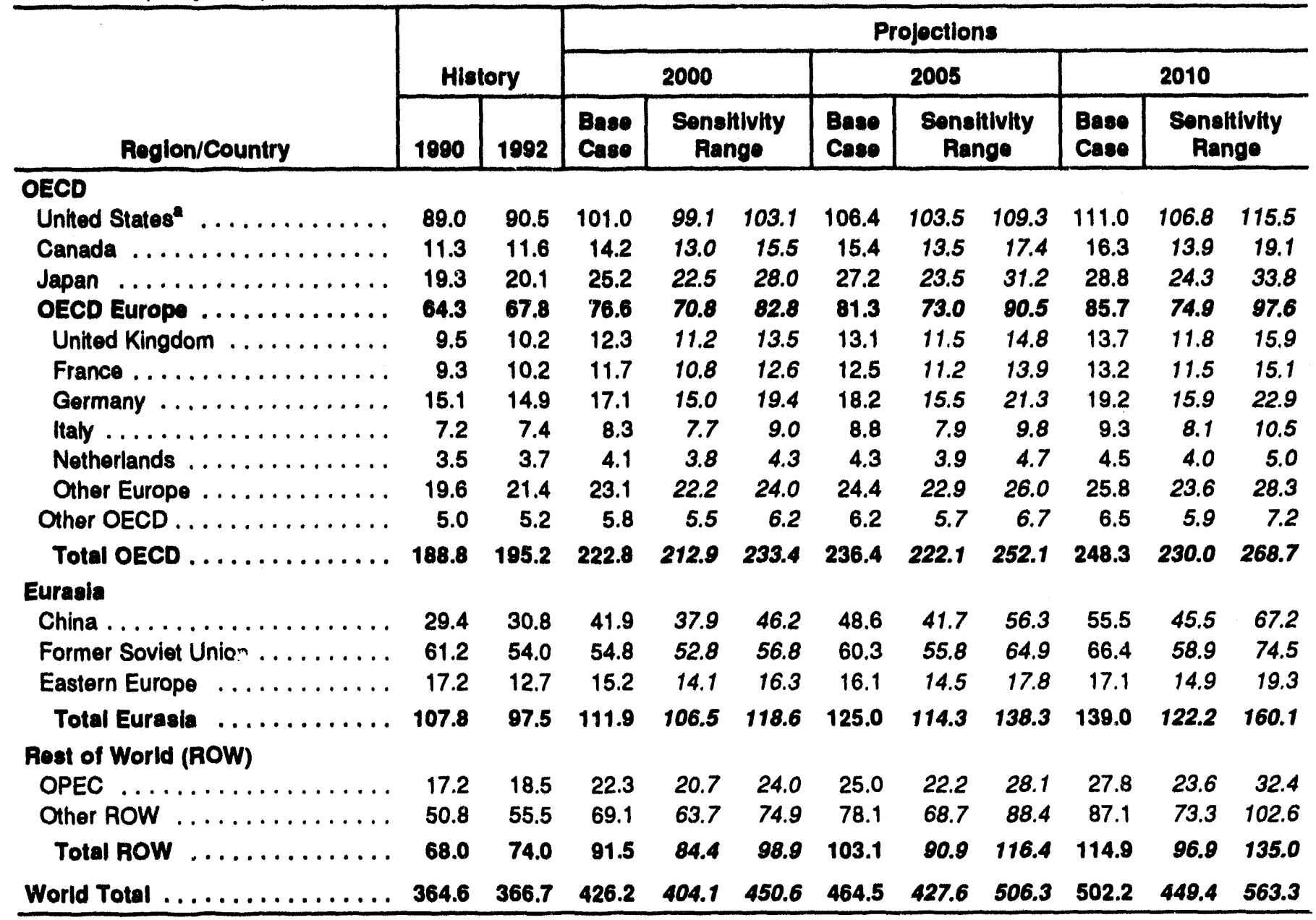

ancludes the 50 States and the District of Columbia. U.S. Territories are included in "Other OECD."

OECD = Organization for Economic Cooperation and Development.

OPEC = Organization of Petroleum Exporting Countries.

Notes: All sensitivity ranges are derived independently and do not necessarily add to totals. Base Case totals may not equal sum of components due to independent rounding. Country amounts include an adjustment to account for electricity trade.

Source: Data from Table A2, divided by the conversion factor 0.9478 . 


\section{Appendix B Analytical Methods}

This appendix briefly describes the methods and sources used to produce the oil dependence index, world oil prices, energy intensity indexes, and sensitivity ranges presented in various figures and tables of the International Energy Outlook 1994 (IEO94). Growth rates for regional gross domestic product (GDP) and oil demand used to determine world oil prices are shown in Tables B1 and B2. Energy intensity values are shown in Table B3. Projections of oil production are shown in Figures B1 and B2. Indexes of Organization of Petroleum Exporting Countries (OPEC) dependence are presented in Figure B3.

\section{Table B1. Average Annual Growth Rates in Real Gross Domestlc Product (GDP) by Region, 1990-2010 (Percent per Year)}

\begin{tabular}{|c|c|}
\hline Region & $\begin{array}{c}\text { GDP } \\
\text { Growth } \\
\text { Rate } \\
\end{array}$ \\
\hline OECD $\ldots \ldots \ldots \ldots \ldots \ldots \ldots \ldots$ & 2.4 \\
\hline OPEC $\ldots \ldots \ldots \ldots \ldots \ldots \ldots$ & 4.2 \\
\hline Other Developing Countries ${ }^{a} \ldots \ldots \ldots \ldots$ & 4.3 \\
\hline Eurasia $\ldots \ldots \ldots \ldots \ldots \ldots \ldots$ & 2.4 \\
\hline Total World ................... & 2.8 \\
\hline
\end{tabular}

aChina is included in Eurasia.

OECD = Organization for Economic Cooperation and Development.

OPEC = Organization of Petroleum Exporting Countries.

Sources: The WEFA Group, World Economic Service and World Economic Service Historical (June 1992) and World Economic Outlook (Fobruary and July 1993).

\section{World Oil Prices}

World oil prices are projected using the Oil Market Simulation (OMS) model. The OMS model makes up part of the International Energy Module (IEM) of the new National Energy Modeling System (NEMS), which was first used to produce the projections presented in the Annual Energy Outlook 1994 (AEO94). The price paths presented in the IEO94 are consistent with the price projections presented in the AEO94.
Table 82. Average Annual Growth Rates in Oll Demand by Reglon, 1990-2010 (Percent per Year)

\begin{tabular}{c|c|c|c}
\hline Region & $\begin{array}{c}\text { Low } \\
\text { Price } \\
\text { Case }\end{array}$ & $\begin{array}{c}\text { High } \\
\text { Base } \\
\text { Case }\end{array}$ & $\begin{array}{c}\text { Price } \\
\text { Case }\end{array}$ \\
\hline OECD $\ldots \ldots \ldots \ldots \ldots \ldots \ldots \ldots$ & 0.9 & 1.2 & 1.5 \\
OPEC $\ldots \ldots \ldots \ldots \ldots \ldots \ldots$ & 2.2 & 2.2 & 2.2 \\
Other Developing Countries ${ }^{a} \ldots$ & 2.2 & 2.5 & 2.7 \\
Eurasia $\ldots \ldots \ldots \ldots \ldots \ldots \ldots$ & 0.7 & 1.2 & 1.6 \\
Total World $\ldots \ldots \ldots \ldots \ldots \ldots$ & 1.2 & 1.5 & 1.8 \\
\hline
\end{tabular}

${ }^{a}$ China is included in Eurasia.

$O E C D$ = Organization for Economic Cooperation and Development.

OPEC = Organization of Petroleum Exponting Countries.

Sources: Energy Information Administration, National Energy Modeling System (run AEO94B.D1221934), low world oil price scenario (run LWOP94.D1221932), and high world oil price scenario (run HWOP94.D1221932).

Figure B1. OPEC Oll Production, 1970-2010

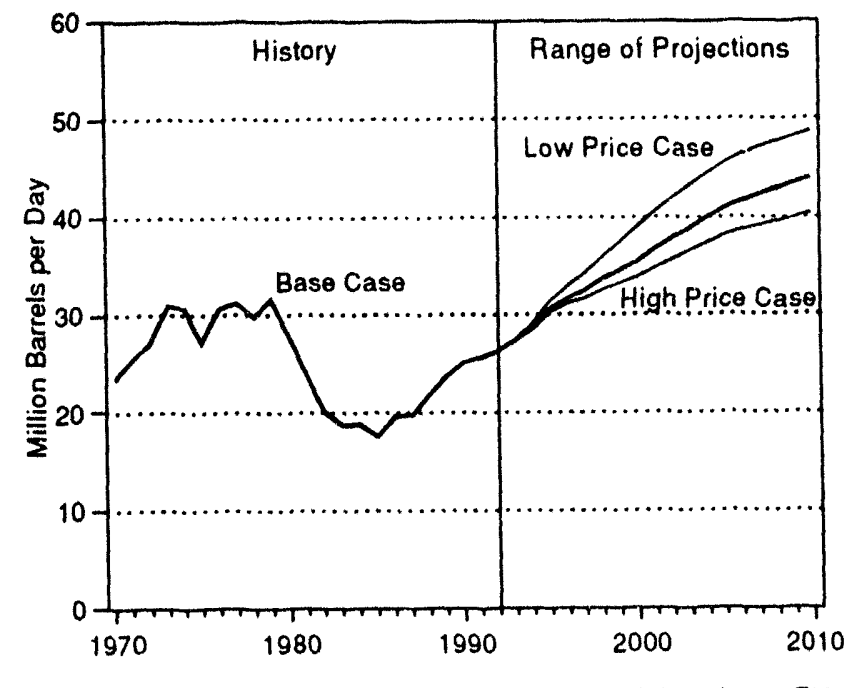

Sources: History: Energy Information Administration (ElA), International Petroleum Statistics Report, DOE/ElA-0520(93/07), Table 4.3. Projections: EIA, Annual Energy Outlook 1994, DOE/EIA0383(94), Tables A19. D19, and E19. 
Table B3. Energy Intenslity by Reglon, 1980-2010

(Thousand Btu per 1985 Dollar of GDP)

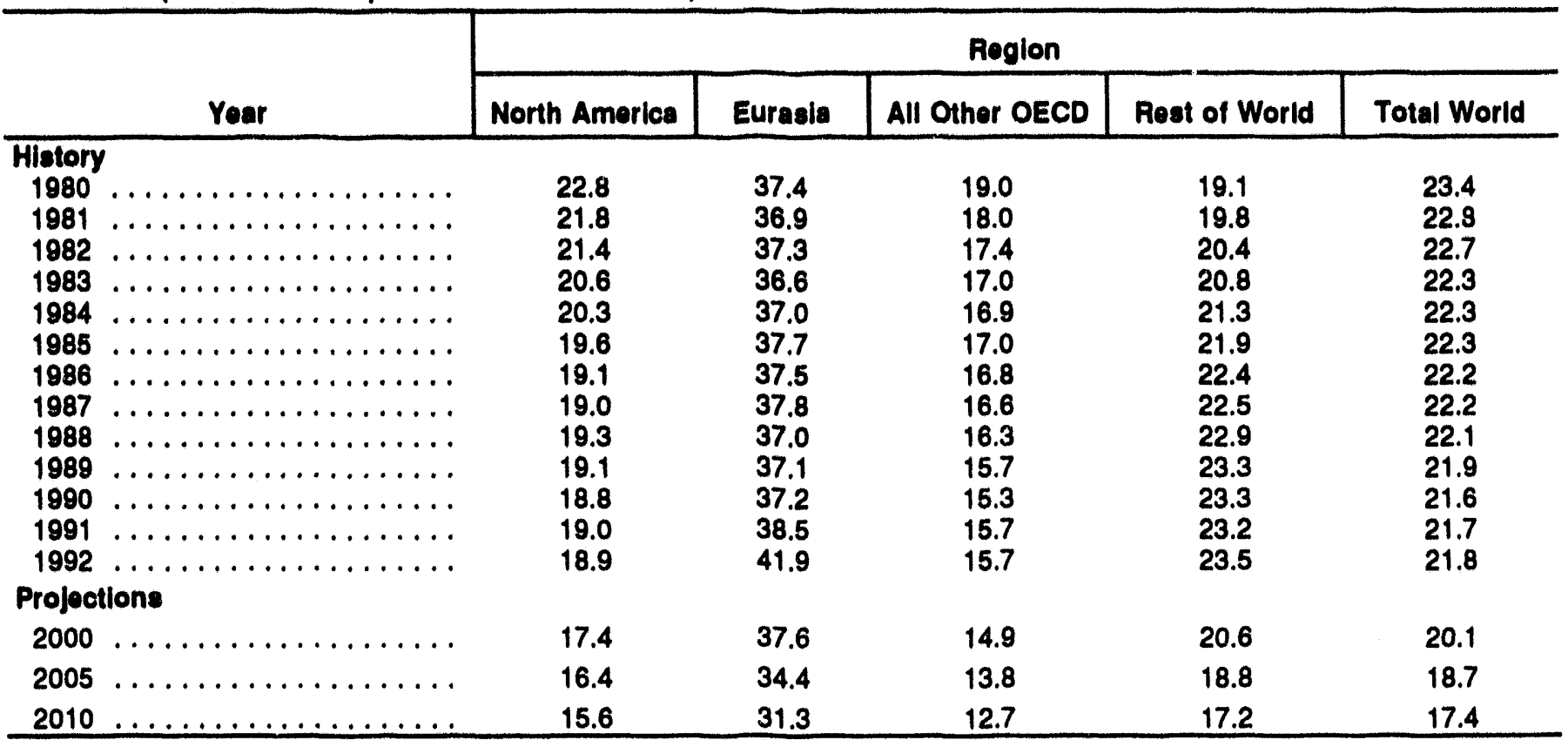

OECD - Organization for Economic Cooperation and Development.

Notes: Energy intensity is equal to total energy consumption per dollar of real gross domestic product (GDP). North America consists of the OECD members Canada and the United States.

Sources: History-Wharton Econometric Forecasting Associates, World Economic Services and World Economic Service Historical Data (June 1993); and Energy Information Administration (ElA), International Energy Annual 1992, DOE/EIA-0219(92). Projections-Derived from Wharton Econometric Forecasting Associates, World Economic Outlook (February and October 1993); and EIA, Annual Energy Outlook 1994, DOE/EIA-0383(94); and World Energy Projection System, 1994.

Figure B2. Non-OPEC OII Production, 1970-2010

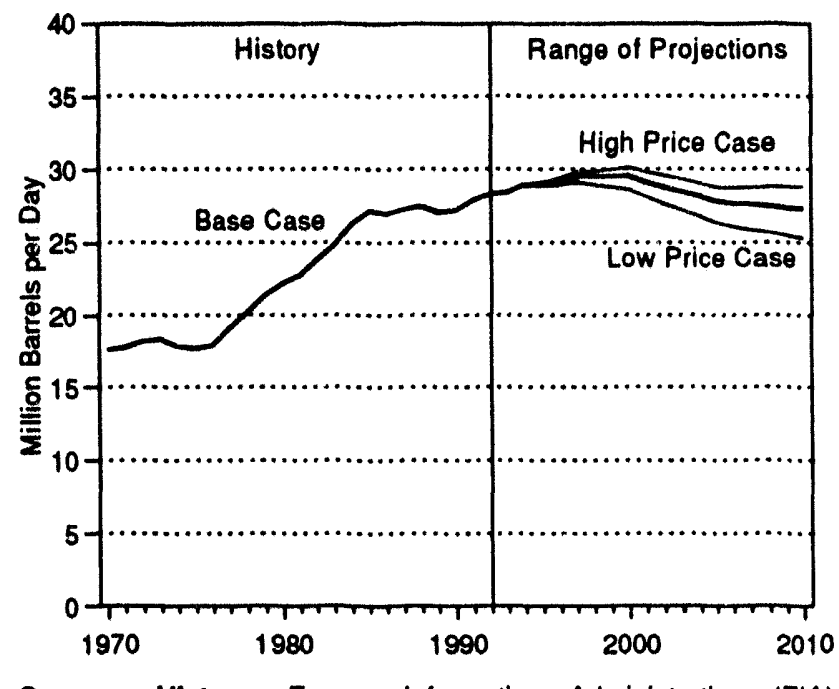

Sources: History: Energy Information Administration (EIA), International Petroleum Statistics Report, DOE/EIA-0520(93/07), Table 4.3. Projectione: EIA, Annual Energy Outlook 1994, DOE/EIA0383(94), Tables A19, D19, and E19.

\section{Figure B3. World Dependence on OPEC OII, 1973-2010}

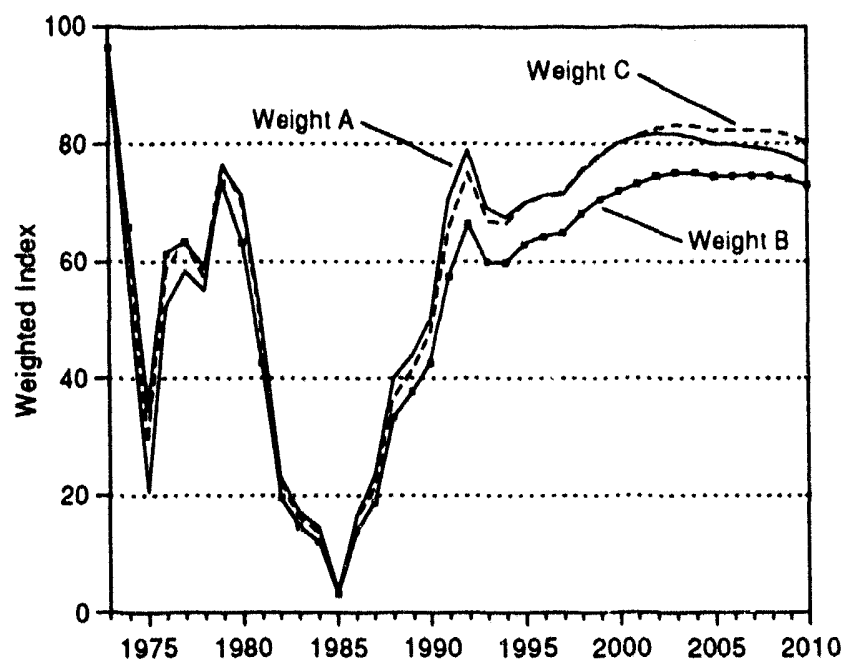

Sources: History: Energy Intormation Administration (EIA), Annual Energy Reviow 1992, International Petroleum Statistics Report, DOE/EIA-0520(93/12); and International Energy Annual 1992, DOE/EIA-0219(92). Projections: ElA, Annual Energy Outlook 1994; National Energy Model System reference scenario (run AEO94B.D1221934); Oil Market Simulation Model, 1994; and World Energy Projection System, 1994. 
The level of oll production by countries in the OPEC is a key factor determining the world oil price projections in IEO94. Non-OPEC production, worldwide regional economic growth rates, associated regional demand for oil, and the level of net oil exports from Eurasia (the former Soviet Union, China, and Eastern Europe) also affect world ol: price. The assumptions for these variables are given below.

OPEC oil production is assumed to increase throughout the projection period, making OPEC the source for essentially the entire worldwide increase in oil production expected over this period (Figure B1). This assumption is made because OPEC's member nations contain more than three-quarters of the world's total reserves-in the neighborhood of 772 billion barrels at the end of 1993. The three world oil price paths presented in IEO94 thus result principally from considering the results of three different paths for future production that OPEC might follow.

The projections of world oil price and U.S. oll consumption and production are interdependent within the NEMS. Worldwide demand for oil and international oil production also vary with world oil prices. The final projected values for OPEC production associated with the final world oil price paths are shown in Figure B1.

Non-OPEC oil production is assumed to follow a fairly flat path-with a slight rise through the year 2000 and a modest decline thereafter, as declining production in some parts of the world is offset by increases in other regions (Figure B2). One fixed path for non-OPEC oil production is assumed initially for all oil price projections. As with OPEC oil production, non-OPEC production depends on the level of world oil prices. Thus, three levels of non-OPEC production result from the projection process, each consistent with one of the three oil-price paths. Production is higher with higher prices, as certain marginal wells become profitable, while lower production levels are associated with lower world oil prices. The final non-OPEC production paths are shown in Figure B2.

The assumed growth rates for gross domestic product (GDP) in real terms for various regions of the world are shown in Table B1. This set of growth rates for GDP was assumed to hold throughout the projection process. The GDP growth rate assumptions came basically from selected issues of the WEFA Group's World Economic Outlook. The WEFA GDP growth rates have been used for all regions of the world except the developing countries, for which the GDP growth rates were assumed to be about one percentage point lower per year than the WEFA values. This adjustment is made to provide a better balance between sustainable economic growth and oil production and prices. The values for growth in oil demand calculated in the International Energy Module, which depend on oil price levels as well as GDP growth rates, are shown in Table B2. The different rates of growth for oil consumption reflect the differences in world oil prices.

Economic growth and oil consumption in Eurasia are projected to decline through 1995, with virtually all the decline occurring in the former Soviet Union (FSU). Oil production in the FSU is assumed to decline through 1995, but to remain well above its domestic oil consumption. After 1995, oil production and consumption in the FSU are expected to increase, with the whole region as an entity expected to remain a net exporter of oil through 2010. In contrast, China is expected to become a net importer of oil before 1995 and remain so through 2010. Currently, Eastern Europe depends on imports for most of its oil and will continue to do so. However, Eurasia as a region, principally the FSU, is assumed to remain a net exporter of oil to the rest of the world over the entire projection period. Eurasian net oil exports influence world oil prices by contributing to world oil supplies. With abundant world oil supplies, including Eurasian net exports of 3.2 million barrels per day by 2010, world oil prices are low. Low world supplies, where Eurasian net exports approach zero by 2010 , produce the higher prices presented in IEO94.

\section{Index of OPEC Dependence}

The Index of OPEC Dependence (IOD) consists of a weighted average of the indexed values of three variables: (1) the percentage of world oil consumption coming from OPEC, (2) the level of excess crude oil production capacity available in any given year, and (3) the level of petroleum stocks in the countries of the Organization for Economic Cooperation and Development (OECD). Each variable is indexed in such a way that the highest value (greatest dependence) in that series equals 100 and the lowest value equals zero.

The indexed values are then weighted to illustrate the IOD, as shown in Figure 20 on page 21. 
Because the weights are fudgmental, alternative weighting schemes are presented here. Figure B3 shows the results of using each of the three different weighting schemes. The weighting schemes are presented below:

\begin{tabular}{c|c|c|c}
\hline \multirow{2}{*}{ Paramotor } & \multicolumn{3}{|c}{ Sorles } \\
\cline { 2 - 4 } & A & B & C \\
\hline Excess Capacity $\ldots \ldots \ldots$ & 70 & 50 & 60 \\
OPEC Share $\ldots \ldots \ldots$. & 15 & 30 & 30 \\
Stocks $\ldots \ldots \ldots \ldots \ldots$ & 15 & 20 & 10 \\
\hline
\end{tabular}

The basic pattern of the IOD does not vary significantly as different weighting schemes are applied because the underlying series tend to move in the same direction over time. The values for Series B are presented in Figure 20 on page 21.

\section{Sensitivity Ranges}

The sensitivity of energy projections to changes in major assumptions is conveyed in the Annual Energy Outlook 1994 through five different scenarios: Reference, High Economic Growth, Low Economic Growth, High Oil Price, and Low Oil Price. The names of the scenarios indicate the changes in assumption made from the Reference assumptions; and the scenario values reflect the projected results of these changed assumptions.

In IEO94, sensitivity is conveyed by a set of ranges surrounding a Base Case, rather than by a unique set of scenarios. For example, the high range for total energy consumption for each country or country group and for each projected year is determined by: (1) assuming higher rates of economic growth (1.0 percentage points above Base Case rates), calculating the resulting differences in consumption from the Base Case levels, and squaring these differences; (2) assuming a higher ratio of total energy consumed per dollar of gross domestic product ( 30 percent higher than Base Case ratios), calculating resulting differences from Base Case levels, and squaring these differences; ( 3 ) adding the squared differences from the first two steps, and then taking the square root of that sum; and (4) adding the results from step 3 to the Base Case amounts. The result is a range value with a difference from Base Case consumption that is greater than either of the two differences derived by changing a single assumption, but less than the difference that would have resulted if the two changed assumptions had been considered simultaneously. The low range for total energy consumption is determined in the same way, using minus 1.0 percentage points and minus 30 percent in the calculations.

The implied assumption underlying this approach is that it is less likely that the extremes of all possible specified events will occur simultaneously than it is that some set of events between the specified Base Case and the extreme-case levels will transpire. The ranges derived by this approach do not represent confidence intervals or probability levels around the Base Case projections. When considered appropriate, the highand low-range values for regional totals are also determined using this approach-again under the assumption that individual country experiences will likely vary from the extremes. Range values for oil consumption and nuclear energy consumption are not derived using the method just described. Projections from the Annual Energy Outlook 1994 (AEO94) and the International Energy Agency, World Energy Outlook, 1993 represent the oil consumption range. Nuclear range values are derived from two projections of operable nuclear capacities: a Lower Reference Case and an Upper Reference Case. In this instance, values derived from the Lower Case also serve as the Base Case values.

Similarly, range values for the United States are derived by a different approach. To maintain consistency with projections presented in the AEO94, values are selected directly from five scenarios. These scenarios are presented on the following page according to corresponding projected variables.

A detailed discussion of the determination of ranges is presented in World Energy Projection System Model Documentation Report. The Base Case projections and associated ranges presented here can be replicated using archived personal computer diskettes entitled "World Energy Projection System, 1994," available from EIA's National Energy Information Center (202/586-8800). 


\begin{tabular}{|l|l|}
\hline \multicolumn{1}{|c|}{ Projected Veriable } & \multicolumn{1}{|c|}{ Scenarlo (run Identliter in perentheses) } \\
\hline World oll prices & $\begin{array}{l}\text { Reference case (AEO94B.D1221934) } \\
\text { Low oll price case (LWOP94.D1221932) } \\
\text { High oil price case (HWOP94.D1221932) }\end{array}$ \\
\hline U.S. total energy consumption & $\begin{array}{l}\text { Reference case (AEO94B.D1221934) } \\
\text { High economic growth case (HMAC94.D1221932) } \\
\text { Low economic growth case (LMAC94.D1221932) }\end{array}$ \\
\hline World oil consumption & $\begin{array}{l}\text { Reference case (AEO94B.D1221934) } \\
\text { Low oil price case (LWOP94.D1221932) } \\
\text { High oil price case (HWOP94.D1221932) }\end{array}$ \\
\hline U.S. natural gas consumption & $\begin{array}{l}\text { Reference case (AEO94B.D1221934) } \\
\text { High economic growth case (HMAC94.D1221932) } \\
\text { Low economic growth case (LMAC94.D1221932) }\end{array}$ \\
\hline U.S. coal consumption & $\begin{array}{l}\text { Reference case (AEO94B.D1221934) } \\
\text { High economic growth case (HMAC94.D1221932) } \\
\text { Low economic growth case (LMAC94.D1221932) }\end{array}$ \\
\hline U.S. nuclear consumption & $\begin{array}{l}\text { Reference case (AEO94B.D1221934) } \\
\text { High economic growth case (HMAC94.D1221932) } \\
\text { Low economic growth case (LMAC94.D1221932) }\end{array}$ \\
\hline U.S. renewables consumption & $\begin{array}{l}\text { Reference case (AEO94B.D1221934) } \\
\text { High economic growth case (HMAC94.D1221932) } \\
\text { Low economic growth case (LMAC94.D1221932) }\end{array}$ \\
\hline
\end{tabular}

$\star$ U.S. GOVERNMENT PAINTING OFFICE: 1894 300-813/00005 

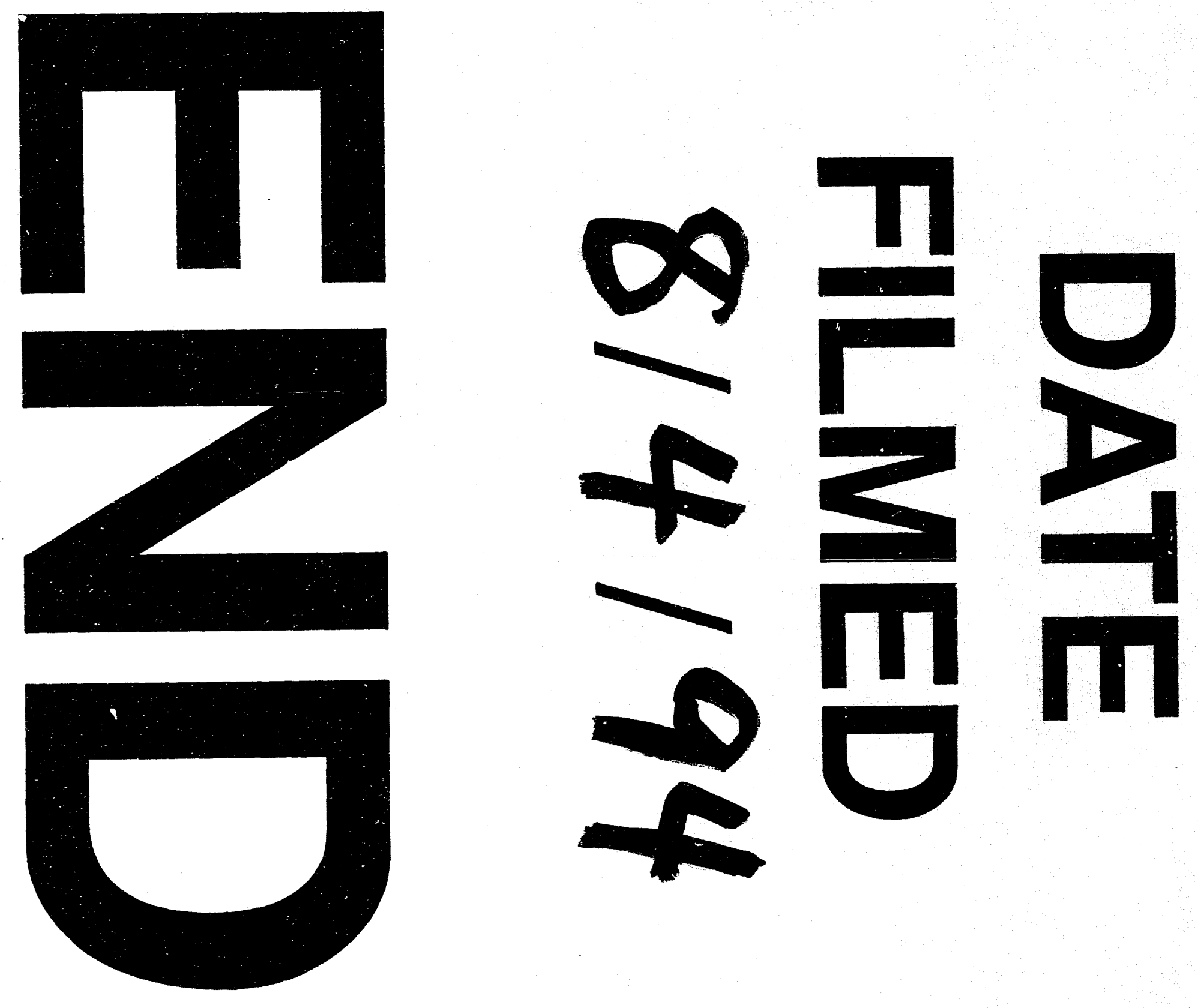


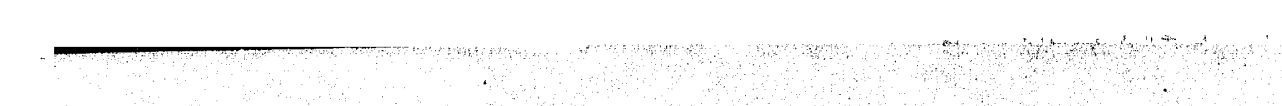

